\title{
Cochrane
}

Library

Cochrane Database of Systematic Reviews

\section{Single dose oral aspirin for acute postoperative pain in adults} (Review)

Derry S, Moore RA

Derry S, Moore RA.

Single dose oral aspirin for acute postoperative pain in adults.

Cochrane Database of Systematic Reviews 2012, Issue 4. Art. No.: CD002067.

DOI: 10.1002/14651858.CD002067.pub2.

www.cochranelibrary.com 
TABLE OF CONTENTS

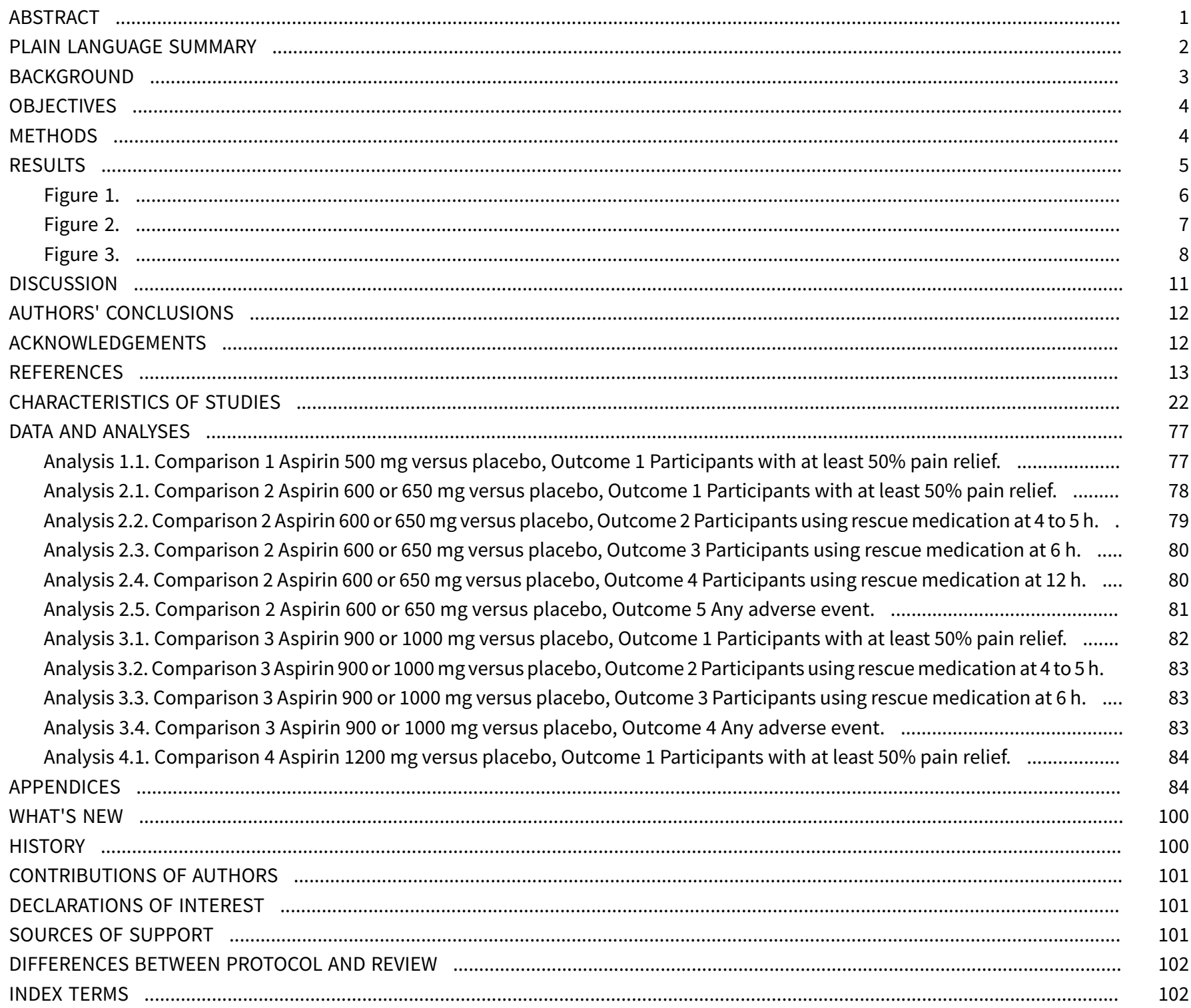


[Intervention Review]

\title{
Single dose oral aspirin for acute postoperative pain in adults
}

\author{
Sheena Derry¹, R Andrew Moore²
}

1Oxford, UK. 2Plymouth, UK

Contact: Sheena Derry, Oxford, Oxfordshire, UK. sheena.derry@retired.ox.ac.uk.

Editorial group: Cochrane Pain, Palliative and Supportive Care Group.

Publication status and date: Stable (no update expected for reasons given in 'What's new'), published in Issue 5, 2019.

Citation: Derry S, Moore RA. Single dose oral aspirin for acute postoperative pain in adults. Cochrane Database of Systematic Reviews 2012, Issue 4. Art. No.: CD002067. DOI: 10.1002/14651858.CD002067.pub2.

Copyright @ 2019 The Cochrane Collaboration. Published by John Wiley \& Sons, Ltd.

\section{A B S T R A C T}

\section{Background}

This review is an update of a previously published review in the Cochrane Database of Systematic Reviews on 'Single dose oral aspirin for acute pain'. Aspirin has been known for many years to be an effective analgesic for many different pain conditions. Although its use as an analgesic is now limited in developed countries, it is widely available, inexpensive, and remains commonly used throughout the world.

\section{Objectives}

To assess the analgesic efficacy and associated adverse events of single dose oral aspirin in acute postoperative pain.

\section{Search methods}

For the earlier review, we identified randomised trials by searching CENTRAL (The Cochrane Library) (1998, Issue 1), MEDLINE (1966 to March 1998), EMBASE (1980 to January 1998), and the Oxford Pain Relief Database (1950 to 1994). We updated searches of CENTRAL, MEDLINE, and EMBASE to January 2012.

\section{Selection criteria}

Single oral dose, randomised, double-blind, placebo-controlled trials of aspirin for relief of established moderate to severe postoperative pain in adults.

\section{Data collection and analysis}

We assessed studies for methodological quality and two review authors extracted the data independently. We used summed total pain relief (TOTPAR) over four to six hours to calculate the number of participants achieving at least $50 \%$ pain relief. We used these derived results to calculate, with $95 \%$ confidence intervals, the relative benefit compared to placebo, and the number needed to treat (NNT) for one participant to experience at least $50 \%$ pain relief over four to six hours. We sought numbers of participants using rescue medication over specified time periods, and time to use of rescue medication, as additional measures of efficacy. We collected information on adverse events and withdrawals.

\section{Main results}

We included 68 studies in which aspirin was used at doses from $300 \mathrm{mg}$ to $1200 \mathrm{mg}$, but the vast majority of participants received either $600 / 650 \mathrm{mg}$ (2409 participants, 64 studies) or 990/1000 mg (380 participants, eight studies). There was only one new study.

Studies were overwhelmingly of adequate or good methodological quality. NNTs for at least $50 \%$ pain relief over four to six hours were 4.2 (3.9 to 4.8), 3.8 (3.0 to 5.1), and 2.7 (2.0 to 3.8) for $600 / 650 \mathrm{mg}, 900 / 1000 \mathrm{mg}$, and $1200 \mathrm{mg}$ respectively, compared with placebo. Type of pain model had no significant impact on the results. Lower doses were not significantly different from placebo. These results do not differ from those of the earlier review. 
Fewer participants required rescue medication with aspirin than with placebo over four to eight hours postdose, but by 12 hours there was no difference. The number of participants experiencing adverse events was not significantly different from placebo for $600 / 650 \mathrm{mg}$ aspirin, but for $900 / 1000 \mathrm{mg}$ the number needed to treat to harm was 7.5 (4.8 to 17 ). The most commonly reported events were dizziness, drowsiness, gastric irritation, nausea, and vomiting, nearly all of which were of mild to moderate severity.

\section{Authors' conclusions}

Aspirin is an effective analgesic for acute pain of moderate to severe intensity. High doses are more effective, but are associated with increased adverse events, including drowsiness and gastric irritation. The pain relief achieved with aspirin was very similar milligram for milligram to that seen with paracetamol. There was no change to the conclusions in this update.

\section{PLAIN LANGUAGE SUMMARY}

\section{Single dose oral aspirin for acute postoperative pain in adults}

Aspirin is commonly used throughout the world as an over the counter (OTC) analgesic medication used to treat various painful conditions and to reduce fever. This review assessed both the pain-relieving effectiveness and the adverse effects of a single dose of aspirin in acute postoperative pain of moderate to severe intensity. We included 67 studies, with 3111 participants given aspirin in comparisons with 2632 given placebo. Most of the information was for a $600 \mathrm{mg}$ or $650 \mathrm{mg}$ dose. The results confirm that in patients with moderate to severe postoperative pain, about $40 \%$ of those treated with aspirin $600 / 650 \mathrm{mg}$ will experience good levels of pain relief, compared with about $15 \%$ treated with placebo. This level of pain relief is comparable to that experienced with the same dose of paracetamol. In these single dose studies there was no significant difference between aspirin 600/650 mg and placebo for the number of participants experiencing adverse events, but at $900 / 1000 \mathrm{mg}$, twice as many did so, with dizziness, drowsiness, gastric irritation, nausea, and vomiting being the most common events reported. 


\section{B A C K G R O U N D}

This review is an update of a previously published review in the Cochrane Database of Systematic Reviews on 'Single dose oral aspirin for acute pain' (Edwards 2000). The title now states that the review is limited to postoperative pain in adults.

\section{Description of the condition}

Acute pain occurs as a result of tissue damage either accidentally due to an injury or as a result of surgery. Acute postoperative pain is a manifestation of inflammation due to tissue injury. The management of postoperative pain and inflammation is a critical component of patient care.

This is one of a series of reviews whose aim is to increase awareness of the range of analgesics that are potentially available, and present evidence for relative analgesic efficacy through indirect comparisons with placebo, in very similar trials performed in a standard manner, with very similar outcomes, and over the same duration. Such relative analgesic efficacy does not in itself determine choice of drug for any situation or patient, but guides policy-making at the local level. The series covers all analgesics licensed for acute postoperative pain in the UK, and dipyrone, which is commonly used in Spain, Portugal, and Latin-American countries. The results have been examined in an overview (Moore 2011), and important individual reviews include ibuprofen (Derry 2009), paracetamol (Toms 2008), and etoricoxib (Clarke 2009).

\section{Description of the intervention}

\section{Acute pain trials}

Single dose trials in acute pain are commonly short in duration, rarely lasting longer than 12 hours. The numbers of participants are small, allowing no reliable conclusions to be drawn about safety. To show that the analgesic is working, it is necessary to use placebo (McQuay 2005). There are clear ethical considerations in doing this. These ethical considerations are answered by using acute pain situations where the pain is expected to go away, and by providing additional analgesia, commonly called rescue analgesia, if the pain has not diminished after about an hour. This is reasonable, because not all participants given an analgesic will have significant pain relief. Approximately $18 \%$ of participants given placebo will have significant pain relief (Moore 2006), and up to 50\% may have inadequate analgesia with active medicines. The use of additional or rescue analgesia is hence important for all participants in the trials.

Clinical trials measuring the efficacy of analgesics in acute pain have been standardised over many years. Trials have to be randomised and double-blind. Typically, in the first few hours or days after an operation, patients develop pain that is moderate to severe in intensity, and will then be given the test analgesic or placebo. Pain is measured using standard pain intensity scales immediately before the intervention, and then using pain intensity and pain relief scales over the following four to six hours for shorteracting drugs, and up to 12 or 24 hours for longer-acting drugs. Pain relief of half the maximum possible pain relief or better (at least $50 \%$ pain relief) is typically regarded as a clinically useful outcome. For patients given rescue medication it is usual for no additional pain measurements to be made, and for all subsequent measures to be recorded as initial pain intensity or baseline (zero) pain relief (baseline observation carried forward). This process ensures that analgesia from the rescue medication is not wrongly ascribed to the test intervention. In some trials the last observation is carried forward, which gives an inflated response for the test intervention compared to placebo, but the effect has been shown to be negligible over four to six hours (Moore 2005). Patients usually remain in the hospital or clinic for at least the first six hours following the intervention, with measurements supervised, although they may then be allowed home to make their own measurements in trials of longer duration.

Knowing the relative efficacy of different analgesic drugs at various doses can be helpful. An example is the relative efficacy in the third molar extraction pain model (Barden 2004).

\section{Aspirin}

Aspirin (acetylsalicylic acid, (ASA)) is an analgesic and a nonsteroidal anti-inflammatory drug (NSAID); it also has antipyretic (reducing fever) and anti-inflammatory effects. Aspirin has been known to be an effective analgesic for many years. Rheumatism has affected man since the great river cultures of the Middle East. Clay tablets from the Sumerian period described the use of willow leaves to treat it. The Egyptians were also aware of the pain-relieving effects of potions made from myrtle or willow leaves. Edward Stone, a vicar from Chipping Norton in Oxfordshire, is generally recognised as the man who gave the first scientific description of the effects of willow bark. In 1763 he wrote a letter to the Earl of Macclesfield, then President of the Royal Society in London, in which he described treating patients suffering from ague (fever) with 20 grains (approximately a $1000 \mathrm{mg}$ ) of powdered willow bark in a dram of water every four hours. Today aspirin is commonly used throughout the world for many different pain conditions.

When used as an analgesic for adults, aspirin is given orally at a dose of 300 to $1000 \mathrm{mg}$ every four to six hours, with a maximum of 4000 $\mathrm{mg}$ daily. In some countries/the UK it is contraindicated in children under 16 years (due to its association with Reye's syndrome), except in certain conditions, such as Kawasaki disease. Much lower doses (typically $75 \mathrm{mg}$ or $81 \mathrm{mg}$ daily) are used for antiplatelet effects to prevent cardiovascular events.

Aspirin use is associated with a high incidence of gastrointestinal irritation and occult (hidden) blood loss, and occasional overt gastrointestinal bleeding, even with short-term use. Dispersible and enteric coated formulations have been developed to limit these gastrointestinal adverse effects. The availability of alternative drugs with better tolerability has reduced the use of aspirin for pain relief in many countries in recent years. In the UK in 2010 just over 4 million prescriptions for aspirin were written in primary care, mostly for $300 \mathrm{mg}$ dispersible or enteric coated tablets (PCA 2011); in 2009 the number was almost 4.6 million, while in 2006 it was just over 6 million. In other parts of the world, where newer alternatives are either not available or are too expensive, aspirin may still be the main analgesic in use.

\section{How the intervention might work}

Clinicians prescribe NSAIDs on a routine basis for a range of mildto-moderate pain. NSAIDs are the most commonly prescribed analgesic medications worldwide, and their efficacy for treating acute pain has been well demonstrated (Moore 2003). They reversibly inhibit cyclooxygenase (prostaglandin endoperoxide synthase), the enzyme mediating production of prostaglandins and thromboxane A2 (Fitzgerald 2001). Prostaglandins mediate 
a variety of physiological functions such as maintenance of the gastric mucosal barrier, regulation of renal blood flow, and regulation of endothelial tone. They also play an important role in inflammatory and nociceptive processes. Aspirin's main mechanism of action is irreversible inhibition of the enzyme cyclooxygenase 1 (COX-1) and modification of cyclooxygenase 2 (COX-2), which interferes with thromboxane and prostaglandin synthesis, and increases production of anti-inflammatory lipoxins. Other non-steroidal anti-inflammatory drugs cause reversible inhibition of the cyclooxygenases.

\section{Why it is important to do this review}

Aspirin is an inexpensive and effective analgesic available worldwide, and therefore an important drug for treating pain.

\section{O B JECTIVES}

To assess the efficacy and adverse effects of single dose oral aspirin for acute postoperative pain using methods that permit comparison with other analgesics evaluated in standardised trials using almost identical methods and outcomes.

\section{METHODS}

\section{Criteria for considering studies for this review \\ Types of studies}

Included studies were double-blind trials of single dose oral aspirin compared with placebo for the treatment of moderate to severe postoperative pain in adults, with at least 10 participants randomly allocated to each treatment group. We included multiple dose studies if appropriate data from the first dose were available, and cross-over studies provided that data from the first arm were presented separately.

We excluded the following:

- review articles, case reports, and clinical observations;

- studies of experimental pain;

- studies where pain relief is assessed only by clinicians, nurses, or carers (i.e. not patient-reported);

- studies of less than four hours duration or studies that fail to present data over four to six hours postdose.

For postpartum pain, we included studies if the pain investigated was due to episiotomy or Caesarean section irrespective of the presence of uterine cramps; we excluded studies investigating pain due to uterine cramps alone.

\section{Types of participants}

We included studies of adult participants (> 15 years) with established postoperative pain of moderate to severe intensity following day surgery or in-patient surgery. For studies using a visual analogue scale (VAS), we considered that pain intensity of greater than $30 \mathrm{~mm}$ equated to pain of at least moderate intensity (Collins 1997).

\section{Types of interventions}

Aspirin or matched placebo administered as a single oral dose for postoperative pain.

\section{Types of outcome measures}

Data collected included the following if available:

- participant characteristics;

- patient reported pain at baseline (physician, nurse, or carer reported pain was not included in the analysis);

- patient reported pain relief expressed at least hourly over four to six hours using validated pain scales (pain intensity and pain relief in the form of VAS or categorical scales, or both);

- patient global assessment of efficacy (PGE), using a standard categorical scale;

- time to use of rescue medication;

- number of participants using rescue medication;

- number of participants with one or more adverse events;

- number of participants with serious adverse events;

- number of withdrawals (all-cause, adverse events).

\section{Search methods for identification of studies}

\section{Electronic searches}

We searched the following databases for the original review:

- the Cochrane Central Register of Controlled Trials (CENTRAL) (The Cochrane Library) (1998, Issue 1);

- MEDLINE (1966 to March 1998);

- EMBASE (1980 to January 1998);

- Oxford Pain Relief Database (1950 to 1994; Jadad 1996a).

We updated searches using the following electronic databases:

- the Cochrane Central Register of Controlled Trials (CENTRAL) (The Cochrane Library) (issue 1, 2012);

- MEDLINE via Ovid (25 January 2012);

- EMBASE via Ovid (25 January 2012).

See Appendix 1 for the MEDLINE search strategy, Appendix 2 for the EMBASE search strategy and Appendix 3 for the CENTRAL search strategy.

\section{Language}

We did not limit the searches by language.

\section{Searching other resources}

We sought additional studies in reference lists of retrieved articles and reviews. We did not attempt to contact manufacturers since aspirin is so widely available in generic formulations.

\section{Unpublished studies}

We did not contact any manufacturing pharmaceutical company producing this drug for unpublished trial data.

\section{Data collection and analysis}

\section{Selection of studies}

Two review authors independently assessed and agreed the search results for studies that might be included in the review. Disagreements were resolved by consensus or referral to a third review author. 


\section{Quality assessment}

Two review authors independently assessed the included studies for quality using a five-point scale (Jadad 1996b) that considers randomisation, blinding, and study withdrawals and dropouts.

The scale used is as follows.

- Is the study randomised? If yes give one point.

- Is the randomisation procedure reported and is it appropriate? If yes add one point, if no deduct one point.

- Is the study double-blind? If yes then add one point.

- Is the double-blind method reported and is it appropriate? If yes add 1 point, if no deduct one point.

- Are the reasons for patient withdrawals and dropouts described? If yes add one point.

The results are described in the 'Risk of bias in included studies' section below, and 'Characteristics of included studies' table.

\section{Data management}

Two review authors extracted data and recorded them on a standard data extraction form. We entered data suitable for pooling into RevMan 5.1 (RevMan 2011).

\section{Data analysis}

For each study we converted the mean summed total pain relief (TOTPAR), summed pain intensity difference (SPID), VAS TOTPAR or VAS SPID (Appendix 4) values for active and placebo to \%maxTOTPAR or \%maxSPID by division into the calculated maximum value (Cooper 1991), and calculated the proportion of participants in each treatment group who achieved at least 50\%maxTOTPAR using verified equations (Moore 1996; Moore 1997a; Moore 1997b). We then converted these proportions into the number of participants achieving at least 50\%maxTOTPAR by multiplying by the total number of participants in the treatment group. We used this information on the number of participants with at least 50\%maxTOTPAR for active and placebo to calculate relative benefit or relative risk, and number needed to treat to benefit (NNT).

We accepted the following pain measures for the calculation of TOTPAR or SPID:

- five-point categorical pain relief (PR) scales with comparable wording to "none, slight, moderate, good or complete";

- four-point categorical pain intensity (PI) scales with comparable wording to "none, mild, moderate, severe";

- VAS for pain relief;

- VAS for pain intensity.

If none of these measures were available, we used the number of participants reporting "very good or excellent" on a five-point categorical global scale with the wording "poor, fair, good, very good, excellent" for the number of participants achieving at least $50 \%$ pain relief (Collins 2001).

For each treatment group we extracted the number of participants reporting treatment-emergent adverse effects, and calculated relative benefit and risk estimates with 95\% confidence intervals (CI) using a fixed-effect model (Morris 1995). We calculated NNT and number needed to treat to harm (NNH) and $95 \% \mathrm{Cl}$ using the pooled number of events using the method devised by Cook and Sackett (Cook 1995). We assumed a statistically significant difference from control when the $95 \% \mathrm{Cl}$ of the relative risk (RR) or relative benefit (RB) did not include the number one. We examined homogeneity visually using L'Abbé plots (L'Abbé 1987).

We planned subgroup analyses to determine the effect of dose and presenting condition (pain model), and sensitivity analyses for high versus low (two or fewer versus three or more) quality trials. A minimum of two studies and 200 participants had to be available in any subgroup or sensitivity analysis (Moore 1998), which was restricted to the primary outcome $(50 \%$ pain relief over four to six hours) and the dose with the greatest amount of data (600/650 mg).

\section{RE S U L T S}

\section{Description of studies}

\section{Included studies}

We identified 72 publications, reporting on 67 studies with 5743 participants, that satisfied our inclusion criteria. We included two studies that were not in the earlier review: Gaston 1984 had been excluded because of non-standard labelling of the pain scale, but an adjustment could be made for this, and Seymour 2003 was published after the earlier review. We identified three further studies, Beaver 1983, Cooper 1983, and Lindenmuth 1989, as reporting on the same studies as Forbes 1982, Mardirossian 1985, and Clark 1989 respectively, and these are now linked to the parent IDs.

Aspirin was used at doses from $300 \mathrm{mg}$ to $1200 \mathrm{mg}$ : 77 participants took a $300 \mathrm{mg}$ dose (two studies), 135 took $500 \mathrm{mg}$ (two studies), 2379 took $600 \mathrm{mg}$ or $650 \mathrm{mg}$ (63 studies), 380 took $900 \mathrm{mg}$ or $1000 \mathrm{mg}$ (eight studies), 140 took $1200 \mathrm{mg}$ (five studies), and 2632 took placebo (68 studies). Three studies (Holland 1988; Seymour 1986; Seymour 2003) specified using a soluble formulation, and five (Kempf 1987; Markowitz 1985; Parkhouse 1969; Rowe 1985; Seymour 1992) specified using a buffered formulation. The remaining studies are assumed to have used a standard formulation tablet.

Most studies included one or more active comparators, so that a large number of other drugs were used: amfenac, aspirin plus caffeine, aspirin plus codeine, aspirin plus chlorphenasin, aspirin plus mefenamic acid, aspirin plus pentazocine, bicifadine, bromfenac, caffeine, carprofen, chlorphenasin, codeine, codeine plus ibuprofen, codeine plus paracetamol, codeine plus naproxen, diclofenac, diflunisal, dipyrone, etodolac, fenbufen, fendosal, fluproquazone, fluradoline, flurbiprofen, FS205-397, ibuprofen, indoprofen, ketorolac, lornoxicam, meclofenamate, naproxen, oxaprozin, paracetamol, paracetamol plus phenyltoloxamine, piroxicam, propoxyphene, propiram fumarate, proquazone, suprofen, and zomepirac. There were insufficient data to compare a given dose of aspirin with a given dose of any active comparator.

Forty-eight studies treated participants with pain following dental surgery, 12 following episiotomy or other gynaecological surgery, three following orthopaedic surgery, one following urological surgery, and four included participants who had undergone a mixture of types of surgery, or the type of surgery was not specified.

Further details of included studies are in the 'Characteristics of included studies' table. 


\section{Excluded studies}

We excluded five studies that were included in the earlier review because they included participants with pain due to trauma (Herrmann 1980c; Herrmann 1980d), fracture (Kantor 1965; Wang 1979), or fracture and musculoskeletal pain (Okun 1979), which are outside the scope of this update.

In total we excluded 102 studies after reading the full report. Reasons for exclusion are in the 'Characteristics of excluded studies' table.

\section{Risk of bias in included studies}

All included studies were randomised and double-blind. Twenty studies scored 5/5, 25 scored 4/5, 19 scored 3/5, and three scored
2/5 on the Oxford Quality Scale. Points were lost mostly for failure to describe the methods used to ensure randomisation and blinding adequately, but 14 studies failed to report adequately on withdrawals (Boraks 1987; Breivik 1984; Clark 1989; Coutinho 1976; Herbertson 1994; Herrmann 1980a; Herrmann 1980b; London 1983b; Mardirossian 1985; Nelson 1994b; Rowe 1985; Seymour 1986; Seymour 1992; Wang 1982). Details of scores in individual studies are in the 'Characteristics of included studies' table.

We also drew up a 'Risk of bias' table to consider randomisation, allocation, and blinding. We considered no studies at high risk of bias, but the majority did not adequately report the methods used for randomisation and allocation concealment. This may reflect older reporting of methods rather than actual poor study quality (Figure 1).

\section{Figure 1. 'Risk of bias' graph: review authors' judgements about each risk of bias item presented as percentages} across all included studies.

\section{Random sequence generation (selection bias) \\ Allocation concealment (selection bias) \\ Blinding (performance bias and detection bias)}

\section{Low risk of bias}

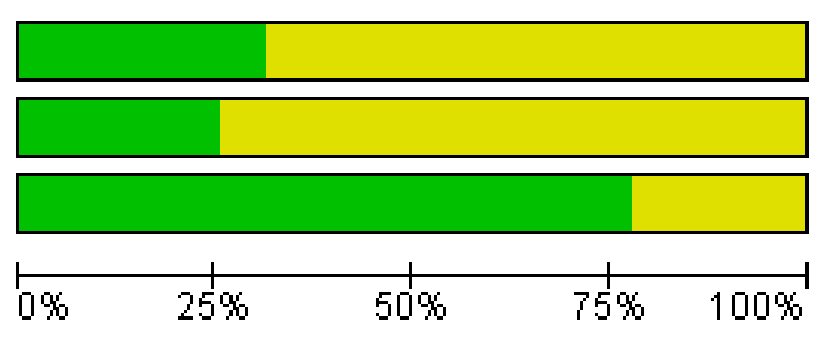

High risk of bias

\section{Effects of interventions}

\section{Participants with at least $50 \%$ pain relief}

\section{Aspirin 300/325 mg versus placebo}

There were insufficient data for analysis of aspirin $300 / 325 \mathrm{mg}$.

\section{Aspirin $500 \mathrm{mg}$ versus placebo}

Two studies (213 participants) compared aspirin $500 \mathrm{mg}$ with placebo (Nelson 1994a; Seymour 1992).

- The proportion of participants with $\geq 50 \%$ pain relief with aspirin $500 \mathrm{mg}$ was $34 \%$ (45/135, range $31 \%$ to $36 \%$ ).

- The proportion of participants with $\geq 50 \%$ pain relief with placebo was $26 \%$ (20/78, range $20 \%$ to $32 \%$ ).
- The relative benefit of treatment compared with placebo was 1.3 (0.82 to 2.0), showing no significant benefit. We did not calculate the number needed to treat (NNT) (Analysis 1.1).

\section{Aspirin 600/650 mg versus placebo}

Sixty studies (4659 participants) compared aspirin 600 or $650 \mathrm{mg}$ with placebo.

- The proportion of participants with $\geq 50 \%$ pain relief with aspirin $600 / 650$ mg was $39 \%$ (905/2339, range $12 \%$ to $90 \%)$.

- The proportion of participants with $\geq 50 \%$ pain relief with placebo was $15 \%$ (352/2320, range $0 \%$ to $46 \%)$.

- The relative benefit of treatment compared with placebo was 2.5 (2.2 to 2.7), giving a NNT of 4.2 (3.9 to 4.8) (Analysis 2.1; Figure 2; Figure 3). 
Figure 2. Forest plot of comparison: 2 Aspirin 600 or $650 \mathrm{mg}$ versus placebo, outcome: 2.1 Participants with at least $50 \%$ pain relief.

\begin{tabular}{|c|c|c|c|c|c|c|c|}
\hline Study or Subgroup & \multicolumn{2}{|c|}{ Aspirin } & \multicolumn{2}{|c|}{ Placebo } & Weight & Risk Ratio & $\begin{array}{c}\text { Risk Ratio } \\
\text { M-H, Fixed, } 95 \% \mathrm{Cl}\end{array}$ \\
\hline \multicolumn{8}{|l|}{ 2.1.1 Dental surgery } \\
\hline Boraks 1987 & 23 & 41 & 10 & 39 & $2.8 \%$ & $2.19[1.20,3.98]$ & \\
\hline Clark 1989 & 12 & 40 & 5 & 40 & $1.4 \%$ & $2.40[0.93,6.19]$ & \\
\hline Cooper 1977 & 13 & 37 & 7 & 40 & $1.9 \%$ & $2.01[0.90,4.48]$ & \\
\hline Cooper 1979a & 27 & 47 & 14 & 58 & $3.5 \%$ & $2.38[1.42,4.00]$ & \\
\hline Cooper 1982 & 14 & 38 & 5 & 46 & $1.3 \%$ & $3.39[1.34,8.56]$ & \\
\hline Cooper 1983 & 21 & 43 & 13 & 44 & $3.6 \%$ & $1.65[0.95,2.86]$ & \\
\hline Cooper 1986 & 13 & 40 & 3 & 41 & $0.8 \%$ & $4.44[1.37,14.42]$ & \\
\hline Cooper 1988 & 4 & 29 & 1 & 33 & $0.3 \%$ & $4.55[0.54,38.45]$ & \\
\hline Cooper 1991 & 11 & 46 & 5 & 48 & $1.4 \%$ & $2.30[0.86,6.10]$ & \\
\hline Cooper 1992 & 4 & 28 & 0 & 26 & $0.1 \%$ & $8.38[0.47,148.43]$ & \\
\hline Desjardins 1984 & 17 & 40 & 2 & 39 & $0.6 \%$ & $8.29[2.05,33.51]$ & \\
\hline Fliedner 1984 & 25 & 83 & 9 & 87 & $2.4 \%$ & $2.91[1.45,5.86]$ & \\
\hline Forbes 1980 & 15 & 38 & 4 & 43 & $1.0 \%$ & $4.24[1.54,11.68]$ & \\
\hline Forbes 1982 & 17 & 42 & 9 & 38 & $2.6 \%$ & $1.71[0.87,3.37]$ & \\
\hline Forbes 1983 & 12 & 39 & 4 & 40 & $1.1 \%$ & $3.08[1.09,8.72]$ & \\
\hline Forbes 1984 & 6 & 24 & 3 & 28 & $0.8 \%$ & $2.33[0.65,8.34]$ & \\
\hline Forbes 1986 & 10 & 36 & 5 & 42 & $1.3 \%$ & $2.33[0.88,6.20]$ & \\
\hline Forbes 1989 & 9 & 31 & 3 & 33 & $0.8 \%$ & $3.19[0.95,10.72]$ & \\
\hline Forbes 1990a & 17 & 68 & 0 & 75 & $0.1 \%$ & $38.55[2.36,629.01]$ & \\
\hline Forbes $1990 \mathrm{~b}$ & 8 & 32 & 1 & 32 & $0.3 \%$ & $8.00[1.06,60.32]$ & \\
\hline Forbes 1991 & 7 & 41 & 1 & 39 & $0.3 \%$ & $6.66[0.86,51.67]$ & \\
\hline Forbes 1992 & 8 & 38 & 0 & 38 & $0.1 \%$ & $17.00[1.02,284.47]$ & \\
\hline Frame 1986 & 14 & 25 & 12 & 26 & $3.3 \%$ & $1.21[0.71,2.08]$ & \\
\hline Gaston 1984 & 9 & 40 & 6 & 42 & $1.6 \%$ & $1.57[0.62,4.02]$ & \\
\hline Gaston 1986 & 8 & 38 & 4 & 38 & $1.1 \%$ & $2.00[0.66,6.09]$ & \\
\hline Holland 1988 & 18 & 20 & 4 & 20 & $1.1 \%$ & $4.50[1.85,10.94]$ & \\
\hline Jain 1985a & 19 & 29 & 12 & 29 & $3.3 \%$ & $1.58[0.95,2.63]$ & \\
\hline Jain 1986a & 17 & 37 & 11 & 39 & $3.0 \%$ & $1.63[0.88,3.00]$ & \\
\hline Jain 1986b & 6 & 45 & 0 & 47 & $0.1 \%$ & $13.57[0.79,234.01]$ & \\
\hline Kempf 1987 & 6 & 24 & 2 & 23 & $0.6 \%$ & $2.88[0.64,12.82]$ & \\
\hline Mardirossian 1985 & 11 & 40 & 3 & 42 & $0.8 \%$ & $3.85[1.16,12.79]$ & \\
\hline Markowitz 1985 & 5 & 47 & 0 & 53 & $0.1 \%$ & $12.38[0.70,218.00]$ & \\
\hline Mehlisch 1984 & 9 & 49 & 0 & 55 & $0.1 \%$ & $21.28[1.27,356.34]$ & \\
\hline Mehlisch 1990 & 25 & 40 & 16 & 41 & $4.4 \%$ & $1.60[1.02,2.52]$ & \\
\hline Mehlisch 1994 & 18 & 51 & 3 & 52 & $0.8 \%$ & $6.12[1.92,19.51]$ & \\
\hline Nelson 1985 & 9 & 40 & 3 & 39 & $0.8 \%$ & $2.92[0.85,10.01]$ & \\
\hline Nelson 1994b & 26 & 50 & 4 & 50 & $1.1 \%$ & $6.50[2.45,17.27]$ & \\
\hline Or 1988 & 16 & 27 & 8 & 27 & $2.2 \%$ & $2.00[1.03,3.87]$ & \\
\hline Patel 1991 & 11 & 30 & 10 & 30 & $2.8 \%$ & $1.10[0.55,2.19]$ & \\
\hline Rowe 1985 & 9 & 43 & 3 & 41 & $0.8 \%$ & $2.86[0.83,9.83]$ & \\
\hline Sunshine $1983 a$ & 27 & 30 & 11 & 26 & $3.3 \%$ & $2.13[1.34,3.38]$ & \\
\hline Winter 1983a & 24 & 37 & 12 & 35 & $3.4 \%$ & $1.89[1.13,3.17]$ & 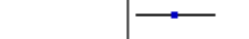 \\
\hline Winter 1983b & 17 & 42 & 12 & 44 & $3.2 \%$ & $1.48[0.81,2.72]$ & \\
\hline Subtotal $(95 \% \mathrm{Cl})$ & & 1685 & & 1748 & $66.3 \%$ & $2.53[2.23,2.88]$ & $\boldsymbol{\nabla}$ \\
\hline Total events & 597 & & 240 & & & & \\
\hline \multicolumn{8}{|c|}{ Heterogeneity: $\mathrm{Chi}^{2}=59.27, \mathrm{df}=42(\mathrm{P}=0.04) ; \mathrm{I}^{2}=29 \%$} \\
\hline \multicolumn{8}{|c|}{ Test for overall effect: $Z=14.31(P=0.00001)$} \\
\hline \multicolumn{8}{|c|}{ 2.1.2 Non-dental surgery } \\
\hline Bloomfield 1967 & 9 & 16 & 6 & 18 & $1.6 \%$ & $1.69[0.77,3.69]$ & \\
\hline Breivik 1984 & 9 & 29 & 5 & 30 & $1.4 \%$ & $1.86[0.71,4.90]$ & \\
\hline Calimlim 1977 & 16 & 23 & 13 & 26 & $3.4 \%$ & $1.39[0.87,2.23]$ & \\
\hline Coutinho 1976 & 13 & 15 & 6 & 15 & $1.7 \%$ & $2.17[1.13,4.15]$ & \\
\hline De Vroey 1977 & 9 & 32 & 1 & 31 & $0.3 \%$ & $8.72[1.17,64.82]$ & \\
\hline Herbertson 1994 & 23 & 50 & 4 & 47 & $1.1 \%$ & $5.41[2.02,14.46]$ & \\
\hline Honig 1978 & 9 & 25 & 1 & 18 & $0.3 \%$ & $6.48[0.90,46.71]$ & \\
\hline Jain 1985a & 19 & 30 & 4 & 30 & $1.1 \%$ & $4.75[1.83,12.31]$ & \\
\hline I nndinn 10020 & 12 & $A \cap$ & 7 & $\sin$ & $10 \alpha$ & 171 In 752 anl & \\
\hline
\end{tabular}


Figure 2. (Continued)

\begin{tabular}{|c|c|c|c|c|c|c|}
\hline ציי & 0 & & & טי & טת ט. & ( \\
\hline Jain 1985a & 19 & 30 & 4 & 30 & $1.1 \%$ & $4.75[1.83,12.31]$ \\
\hline London 1983a & 12 & 40 & 7 & 40 & $1.9 \%$ & $1.71[0.75,3.90]$ \\
\hline London 1983b & 22 & 41 & 14 & 39 & $4.0 \%$ & $1.49[0.90,2.48]$ \\
\hline McQuay 1987 & 6 & 30 & 1 & 30 & $0.3 \%$ & $6.00[0.77,46.87]$ \\
\hline Olsen 1997 & 27 & 50 & 15 & 52 & $4.1 \%$ & $1.87[1.14,3.08]$ \\
\hline Parkhouse 1969 & 85 & 169 & 29 & 85 & $10.7 \%$ & $1.47[1.06,2.05]$ \\
\hline Sunshine 1983b & 14 & 29 & 0 & 31 & $0.1 \%$ & $30.93[1.93,496.05]$ \\
\hline Sunshine $1983 \mathrm{c}$ & 14 & 30 & 0 & 30 & $0.1 \%$ & $29.00[1.81,465.07]$ \\
\hline Sunshine 1988 & 11 & 15 & 4 & 15 & $1.1 \%$ & $2.75[1.13,6.72]$ \\
\hline Wang 1982 & 10 & 25 & 2 & 25 & $0.6 \%$ & $5.00[1.22,20$ \\
\hline Subtotal $(95 \% \mathrm{Cl})$ & & 649 & & 562 & $33.7 \%$ & $2.31[1.93,2.7$ \\
\hline Total events & 308 & & 112 & & & \\
\hline
\end{tabular}

Heterogeneity: $\mathrm{Chi}^{2}=32.80, \mathrm{df}=16(\mathrm{P}=0.008) ; \mathrm{I}^{2}=51 \%$

Test for overall effect: $Z=9.25$ ( $P<0.00001)$

Total $(\mathbf{9 5} \% \mathrm{Cl}) \quad 2334 \quad 2310 \quad \mathbf{1 0 0 . 0} \% \quad 2.46[2.22,2.72]$
Total events $\quad 905 \quad 352$
Heterogeneity: $\mathrm{Ch}^{2}=93.51, \mathrm{df}=59(\mathrm{P}=0.003) ; \mathrm{I}^{\mathbf{2}}=37 \%$
Test for overall effect: $\mathrm{Z=17.04}(\mathrm{P}=0.00001)$
Test for subqroup differences: $\mathrm{Chi}^{\mathbf{2}}=0.71, \mathrm{df}=1(\mathrm{P}=0.40), \mathrm{I}^{\mathbf{2}}=0 \%$

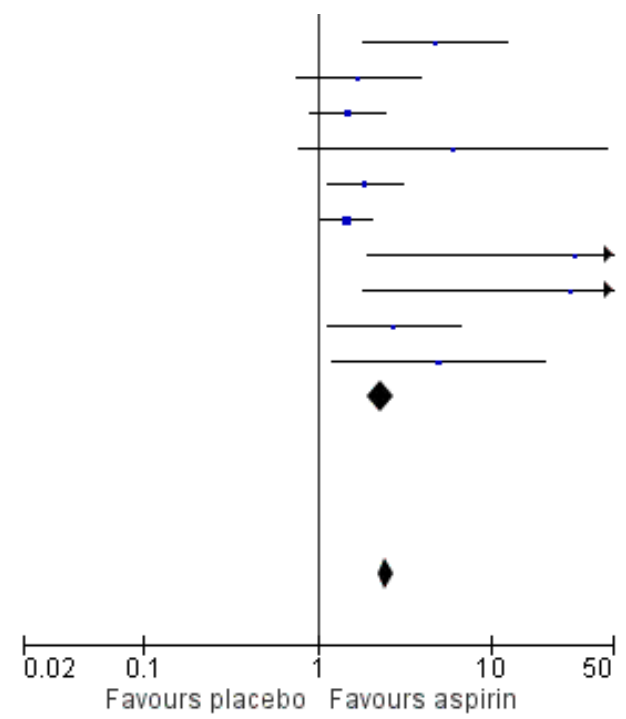

Figure 3. L'Abbé plot showing $\geq 50 \%$ pain relief for all studies using $600 / 650 \mathrm{mg}$ aspirin versus placebo. Each circle represents a different study. Size of circle is proportional to size of study.

At least $50 \%$ maximum pain relief (\%) with active

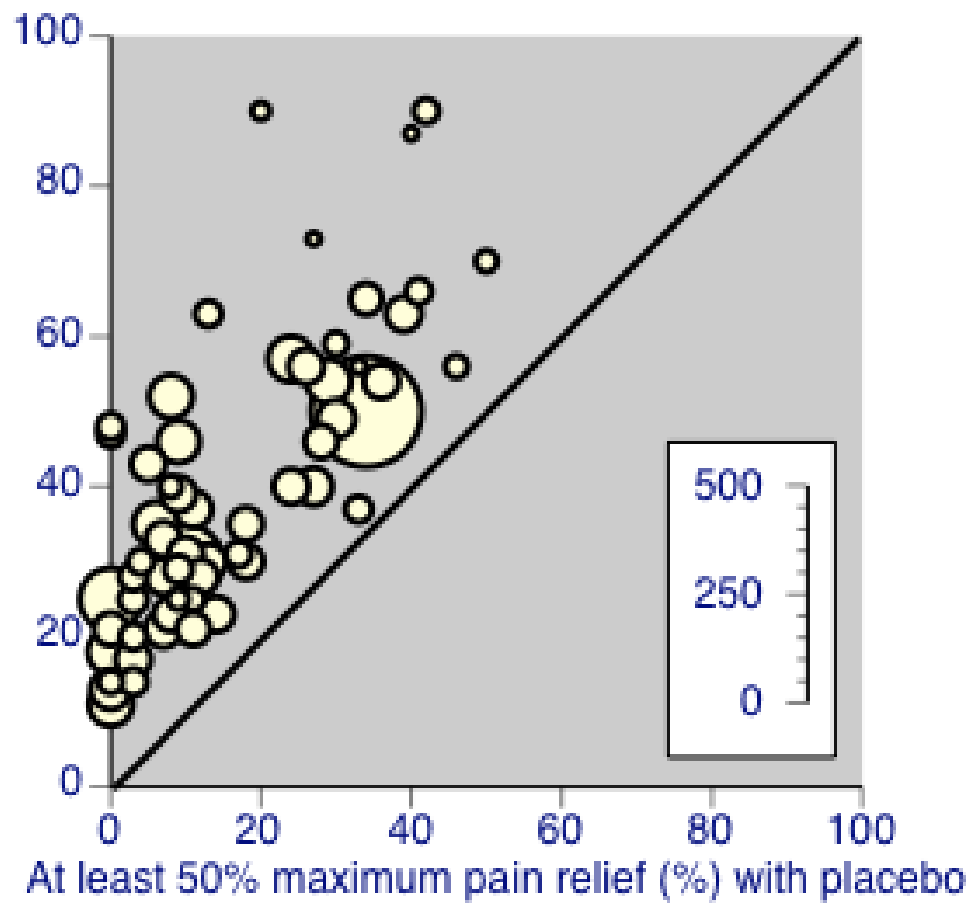

\section{Subgroup analysis for pain model}

For the 43 studies in dental pain only (3433 participants) the relative benefit (RB) was 2.5 (2.2 to 2.9), giving a NNT of 4.6 (4.1 to 5.3), while for the 17 studies in other types of surgery (1211 participants), the RB was 2.3 (1.9 to 2.8), giving a NNT of 3.6 (3.0 to 4.5). There was no significant difference between the different types of surgery in these studies (Analysis 2.1).
Sensitivity analysis for study quality

For the 57 studies scoring $\geq 3 / 5$ on the Oxford Quality Score (4373 participants), the RB was 2.4 (2.2 to 2.7), giving a NNT of 4.3 (3.8 to $4.8)$, while for the three studies scoring only $2 / 5$ (257 participants), the RB was 2.9 (1.9 to 4.6), giving a NNT of 3.4 (2.5 to 5.4). There was no significant difference between studies scoring the minimum for inclusion in this review (2/5), and those with higher scores. 


\section{Aspirin $1000 \mathrm{mg}$ versus placebo}

Six studies (618 participants) compared aspirin $1000 \mathrm{mg}$ with placebo (Forbes 1990a; Herrmann 1980a; Herrmann 1980b; Lehnert 1990; Seymour 1992; Seymour 2003).

- The proportion of participants with $\geq 50 \%$ pain relief with aspirin $1000 \mathrm{mg}$ was $41 \%$ (138/340, range $24 \%$ to $64 \%$ ).

- The proportion of participants with $\geq 50 \%$ pain relief with placebo was $14 \%$ (40/278, range $0 \%$ to $32 \%)$.

- The relative benefit of treatment compared with placebo was 2.7 (2.0 to 3.7), giving a NNT of 4.2 (3.8 to 4.6) (Analysis 3.1).

\section{Aspirin 1200 mg versus placebo}

Three studies (249 participants) compared aspirin $1000 \mathrm{mg}$ with placebo (Holland 1988; London 1983b; Seymour 1986).

- The proportion of participants with $\geq 50 \%$ pain relief with aspirin $1200 \mathrm{mg}$ was $61 \%$ (85/140, range $53 \%$ to $70 \%)$.

- The proportion of participants with $\geq 50 \%$ pain relief with placebo was $23 \%$ (25/109, range $7 \%$ to $36 \%)$.

- The relative benefit of treatment compared with placebo was 2.9 (2.0 to 4.2), giving a NNT of 2.7 (2.0 to 3.8) (Analysis 4.1).

\section{Summary of results A: Number of participants with $\geq 50 \%$ pain relief over 6 hours}

\begin{tabular}{lllllll}
\hline Dose & Studies & $\begin{array}{l}\text { Partici- } \\
\text { pants }\end{array}$ & Aspirin (\%) & $\begin{array}{l}\text { Placebo } \\
\text { (\%) }\end{array}$ & Relative benefit (95\% CI) & NNT (95\% CI) \\
\hline $500 \mathrm{mg}$ & 2 & 213 & 33 & 26 & $1.3(0.82$ to 2.0$)$ & not calculated \\
\hline $600 / 650 \mathrm{mg}$ & 60 & 4630 & 39 & 15 & $2.5(2.2$ to 2.7$)$ & $4.2(3.9$ to 4.8$)$ \\
\hline $900 / 1000 \mathrm{mg}$ & 6 & 618 & 41 & 14 & $2.7(2.0$ to 3.7) & $3.8(3.0$ to 5.1$)$ \\
\hline $1200 \mathrm{mg}$ & 3 & 249 & 61 & 23 & $2.9(2.0$ to 4.2$)$ & $2.7(2.0$ to 3.8$)$ \\
\hline
\end{tabular}

Results for the different doses are compatible with a dose response, with the $1200 \mathrm{mg}$ dose being significantly superior to the $600 / 650$ $\mathrm{mg}$ dose $(z=2.416, \mathrm{P}=0.016)$.

\section{Participants using rescue medication at four to five hours}

\section{Aspirin 600/650 mg versus placebo}

Eleven studies (982 participants) compared aspirin 600 or 650 mg with placebo (Boraks 1987; Calimlim 1977; Frame 1986; Jain 1985b; Jain 1986a; London 1983b; Mehlisch 1984; Mehlisch 1994; Parkhouse 1969; Sunshine 1983b; Sunshine 1983c).

- The proportion of participants using rescue medication at four or five hours with aspirin $600 / 650 \mathrm{mg}$ was $27 \%$ (144/530, range $2 \%$ to $71 \%)$.

- The proportion of participants using rescue medication at four or five hours with placebo was $47 \%$ (211/452, range $5 \%$ to $89 \%$ ).

- The relative benefit of treatment compared with placebo was 0.65 (0.56 to 0.76), giving a number needed to treat to prevent one event (NNTp) of 5.1 (3.9 to 7.4) (Analysis 2.2).

\section{Aspirin $1000 \mathrm{mg}$ versus placebo}

Five studies (501 participants) compared aspirin 900/1000 mg with placebo (Herrmann 1980a; Herrmann 1980b; London 1983b; Seymour 1992; Seymour 2003).

- The proportion of participants using rescue medication at four or five hours with aspirin $900 / 1000 \mathrm{mg}$ was $46 \%$ (121/264, range $3 \%$ to $81 \%)$.

- The proportion of participants using rescue medication at four or five hours with placebo was $67 \%$ (158/237, range $26 \%$ to $91 \%$ ).
- The relative benefit of treatment compared with placebo was 0.64 (0.56 to 0.74 ), giving a NNTp of 4.8 (3.4 to 8.1) (Analysis 3.2).

There were insufficient data for analysis of other doses of aspirin for use of rescue medication at four or five hours.

\section{Participants using rescue medication at six to eight hours}

\section{Aspirin 600/650 mg versus placebo}

Twenty studies (1838 participants) compared aspirin 600 or $650 \mathrm{mg}$ with placebo.

- The proportion of participants using rescue medication at six or eight hours with aspirin 600/650 mg was 55\% (530/955, range 3\% to $98 \%)$.

- The proportion of participants using rescue medication at six or eight hours with placebo was $75 \%$ (664/883, range $37 \%$ to $97 \%$ ).

- The relative benefit of treatment compared with placebo was 0.77 (0.73 to 0.82 ), giving a NNTp of 5.1 (4.2 to 6.5) (Analysis 2.3).

\section{Aspirin $1000 \mathrm{mg}$ versus placebo}

Two studies (233 participants) compared aspirin $1000 \mathrm{mg}$ with placebo (Forbes 1990a; Lehnert 1990).

- The proportion of participants using rescue medication at six or eight hours with aspirin $1000 \mathrm{mg}$ was $67 \%$ (78/116, range $51 \%$ to $77 \%)$.

- The proportion of participants using rescue medication at six or eight hours with placebo was $83 \%$ (97/117, range $64 \%$ to $93 \%$ ).

- The relative benefit of treatment compared with placebo was 0.82 (0.71 to 0.95 ), giving a NNTp of 6.4 (3.8 to 21 ) (Analysis 3.3). 
There were insufficient data for analysis of other doses of aspirin for use of rescue medication at six or eight hours.

\section{Participants using rescue medication at 12 hours}

\section{Aspirin 600/650 mg versus placebo}

Four studies (291 participants) compared aspirin 600 or $650 \mathrm{mg}$ with placebo (Clark 1989; Forbes 1982; Forbes 1983; Forbes 1984).

- The proportion of participants using rescue medication at 12 hours with aspirin $600 / 650 \mathrm{mg}$ was $81 \%(117 / 145$, range $65 \%$ to 97\%).
- The proportion of participants using rescue medication at 12 hours with placebo was $86 \%$ (125/146, range $76 \%$ to $90 \%$ ).

- The relative benefit of treatment compared with placebo was 0.95 (0.86 to 1.05). There was no significant difference between treatment groups for use of rescue medication by 12 hours (Analysis 2.4).

There were insufficient data for analysis of other doses of aspirin for use of rescue medication at 12 hours.

\section{Summary of results B: Number of participants using rescue medication}

\begin{tabular}{|c|c|c|c|c|c|c|}
\hline Dose & Studies & $\begin{array}{l}\text { Partici- } \\
\text { pants }\end{array}$ & Aspirin (\%) & $\begin{array}{l}\text { Placebo } \\
(\%)\end{array}$ & Relative benefit (95\% Cl) & NNTp $(95 \% \mathrm{Cl})$ \\
\hline
\end{tabular}

\begin{tabular}{|c|c|c|c|c|c|c|}
\hline \multicolumn{7}{|c|}{ at 4 to 5 hours } \\
\hline $600 / 650 \mathrm{mg}$ & 11 & 1067 & 27 & 47 & $0.58(0.50$ to 0.67$)$ & $4.9(3.9$ to 6.8$)$ \\
\hline $1000 \mathrm{mg}$ & 5 & 501 & 46 & 67 & 0.64 (0.56 to 0.74$)$ & 4.8 (3.4 to 8.1$)$ \\
\hline \multicolumn{7}{|c|}{ at 6 to 8 hours } \\
\hline $600 / 650 \mathrm{mg}$ & 20 & 1838 & 55 & 75 & 0.77 (0.73 to 0.82$)$ & 5.1 (4.2 to 6.5$)$ \\
\hline $1000 \mathrm{mg}$ & 2 & 233 & 67 & 83 & 0.82 (0.71 to 0.95$)$ & 6.4 (3.8 to 21$)$ \\
\hline \multicolumn{7}{|l|}{ at 12 hours } \\
\hline $600 / 650 \mathrm{mg}$ & 4 & 291 & 81 & 86 & 0.95 (0.86 to 1.05$)$ & not calculated \\
\hline
\end{tabular}

\section{Time to use of rescue medication}

\section{Aspirin 600/650 mg versus placebo}

Eighteen studies reported the mean time to use of rescue medication following 600 or 650 mg aspirin (Cooper 1982; Cooper 1983; Cooper 1986; Cooper 1988; Cooper 1991; Desjardins 1984; Forbes 1980; Forbes 1983; Forbes 1984; Forbes 1986; Forbes 1989; Forbes 1990a; Forbes 1990b; Forbes 1991; Forbes 1992; Jain 1986a; Mardirossian 1985; Mehlisch 1990). The weighted mean of the mean time to use was 3.8 hours with aspirin $600 / 650 \mathrm{mg}$, and 3.0 hours with placebo.

A further 11 studies reported the median time to use of rescue medication following 600 or 650 mg aspirin (Clark 1989; Cooper 1992; Forbes 1982; Frame 1986; Herbertson 1994; McQuay 1987; Mehlisch 1994; Nelson 1994b; Olsen 1997; Parkhouse 1969; Sunshine 1988). The weighted mean of the median time to use was 5.2 hours with aspirin $600 / 650 \mathrm{mg}$, and 3.4 hours with placebo.

\section{Aspirin 900/1000 mg versus placebo}

Only one study (Forbes 1990a; 146 participants) reported the mean time to use of rescue medication following $1000 \mathrm{mg}$ aspirin, which was 3.9 hours with aspirin and 2.8 hours with placebo. Two studies reported the mean time to use of rescue medication following 900 or 1000 mg aspirin (Seymour 1992; Seymour 2003; 203 participants). The weighted mean of the mean time to use was 1.9 hours with aspirin $900 / 1000 \mathrm{mg}$, and 1.2 hours with placebo.

There were insufficient data for analysis of other doses of aspirin for this outcome.

\section{Participants with any adverse event}

The most frequently reported effects were dizziness, drowsiness, gastric irritation, nausea, and vomiting. Nearly all effects were of mild or moderate severity and only one study (Herbertson 1994) reported any withdrawals (8/217) due to "medical problems". In this study one event was considered possibly related to study medication (nausea and vomiting with the active comparator, diclofenac), while the other seven were most likely due to the surgical procedure itself.

\section{Aspirin 600/650 mg versus placebo}

Forty-six studies (3633 participants) compared aspirin 600 or 650 $\mathrm{mg}$ with placebo.

- The proportion of participants experiencing any adverse event with aspirin $600 / 650 \mathrm{mg}$ was $11 \%$ (205/1791, range $0 \%$ to $33 \%)$. 
- The proportion of participants experiencing any adverse event with placebo was $9.5 \%$ (175/1842, range $0 \%$ to $38 \%)$.

- The relative harm of treatment compared with placebo was 1.2 (1.0 to 1.4). There was no difference between treatment groups, and we did not calculate the number needed to treat to harm (NNH) (Analysis 2.5).

\section{Aspirin 900/1000 mg versus placebo}

Four studies (404 participants) compared aspirin 900 or 1000 mg with placebo (Forbes 1990a; Holland 1988; Lehnert 1990; Seymour 2003).

- The proportion of participants experiencing any adverse event with aspirin $900 / 1000 \mathrm{mg}$ was $26 \%$ (55/215, range $0 \%$ to $75 \%$ ).

- The proportion of participants experiencing any adverse event with placebo was $12 \%$ (23/189, range $0 \%$ to $41 \%)$.

- The relative harm of treatment compared with placebo was 1.6 (1.1 to 2.3), giving a NNH of 7.5 (4.8 to 17) (Analysis 3.4).

There were insufficient data for analysis of other doses of aspirin for participants experiencing any adverse event.

\section{DISCUSSION}

\section{Summary of main results}

This updated review included essentially the same studies as the earlier review, adding one more recent study with 153 participants in comparisons of aspirin $900 \mathrm{mg}$ with placebo and excluding five studies that were included in the earlier review because they included participants with pain due to trauma (Herrmann 1980c; Herrmann 1980d), fracture (Kantor 1965; Wang 1979), or fracture and musculoskeletal pain (Okun 1979), all outside the scope of this update. Results for the primary outcome of at least $50 \%$ total pain relief over four to six hours are unchanged for doses of $600 / 650$ $\mathrm{mg}$ (number needed to treat (NNT) 4.2), 900/1000 mg (3.8), and $1200 \mathrm{mg}$ (2.7), compared with placebo. There was no statistically significant difference between doses of $600 / 650 \mathrm{mg}$ and $900 / 100$ $\mathrm{mg}$, or between $900 / 1000 \mathrm{mg}$ and $1200 \mathrm{mg}$, but $1200 \mathrm{mg}$ was significantly better than $600 / 650 \mathrm{mg}(z=2.416, \mathrm{P}=0.016)$ for this outcome, based on limited numbers of participants at the higher dose; dose response for analgesics is consistently difficult to determine except in direct comparisons (McQuay 2007). Doses below $500 \mathrm{mg}$ were not significantly better than placebo.

Indirect comparison with other common analgesics, evaluated in the same way, indicate that aspirin $600 / 650 \mathrm{mg}$ has comparable efficacy for at least $50 \%$ pain relief over four to six hours, to celecoxib 200 mg (NNT 4.2 (3.4 to 5.6); Derry 2008), ibuprofen 100 $\mathrm{mg}$ (4.3 (3.2 to 6.4); Derry 2009), and paracetamol 600/650 mg (4.6 (3.9 to 5.5); Toms 2008). This 'mg for $\mathrm{mg}^{\prime}$ equivalence between $600 \mathrm{mg}$ of aspirin and $600 \mathrm{mg}$ paracetamol was also seen in a randomised direct comparison in 1965 (Houde 1965).

This review also considered number of participants requiring rescue medication within defined time periods, and time to use of rescue medication, as additional measures of analgesic efficacy. The NNT to prevent remedication was about 5 over four to eight hours after dosing for both 600/650 mg and 900/1000 mg doses, and not significantly different from placebo by 12 hours for the $600 / 650 \mathrm{mg}$ dose. In most studies, participants were asked to wait for two hours after taking study medication before using rescue medication; the weighted mean of the median time to use of rescue medication was about five hours for $600 / 650 \mathrm{mg}$ aspirin and three hours for placebo. The time to remedication with the $900 / 1000 \mathrm{mg}$ dose was unexpectedly much shorter, at 1.9 hours for aspirin and 1.2 hours for placebo. The reason for much earlier remedication in these participants is unclear, but in one of the studies they could take rescue medication at any time, and in the other they were encouraged to wait for one hour.

There was no difference in the number of participants reporting any adverse event for aspirin 600/650 mg compared with placebo, but for $900 / 1200 \mathrm{mg}$ significantly more aspirin than placebo treated participants experienced adverse events, with a number needed to treat to harm (NNH) of 7.5. Most events were mild or moderate in severity and transient (self limiting, did not require treatment), with only one study reporting any adverse event ("medical problems") withdrawals. Gastrointestinal events (e.g. gastric irritation) and central nervous system events (e.g. nausea) were more common with aspirin, but many of the events reported may be due to the anaesthetic and surgery, rather than the test drug.

\section{Overall completeness and applicability of evidence}

We carried out extensive bibliographic searches for published studies, and identified a large body of data. Studies followed standard methods and the great majority reported data for most of our prespecified outcomes. Single dose studies can tell us whether a drug is an effective analgesic, but do not tell us about the best dosing regimens, or how the drug performs or is tolerated in the longer term.

Adverse events were collected using various methods (spontaneous reporting, observed at clinic visits, questioning, patient diary) over different periods of time. This may have included periods after the use of rescue medication, which may cause its own adverse events. Poor reporting of adverse events in acute pain trials have been noted before (Edwards 1999a). The usefulness of single dose studies for assessing adverse events is questionable, but it is nonetheless reassuring that no serious adverse events were reported, and only one study reported withdrawals due to "medical problems". Long-term multiple dose studies should be used for meaningful analysis of adverse events since, even in acute pain settings, analgesics are likely to be used in multiple doses. The difficulty will be that the postoperative setting is one in which there are many sequelae of surgery and anaesthesia that manifest as adverse events, like nausea, vomiting, or abdominal discomfort, while others, like headache, can be caused by acute caffeine withdrawal over the postoperative period. The main issue is that of rare but serious adverse events, and these are more likely to be found in large observational studies.

\section{Quality of the evidence}

Many of the studies were older, with only one published in the last 10 years, but $65 / 68$ satisfied minimum criteria for adequate quality ( $\geq 3 / 5$ on the Oxford Quality Scale), and $45 / 68$ scored 4 or $5 / 5$. All studies were randomised and double-blind, with points lost due to failure to report sufficient detail of the methods of randomisation and blinding, which may reflect older reporting of methods rather than actual poor study quality. The variability seen between individual studies (Figure 3 ) is that to be expected for their size (Moore 1998). 


\section{Potential biases in the review process}

We identified a large amount of information in studies that satisfied out inclusion criteria, but four studies could not be obtained in full copy in the UK, and we excluded a number of studies either because they did not describe their methods in sufficient detail to determine eligibility, or because they used non-standard methods. It is also possible that there are data that we failed to identify, for example because they are unpublished. However, we think it unlikely that the amount of missing data is large enough to significantly affect the primary outcome, particularly for the $600 / 650 \mathrm{mg}$ dose. An additional 4000 participants would have to have been involved in unpublished trials with zero treatment effects for the NNT for at least $50 \%$ pain relief to increase above 8 , a level we consider to be the limit of clinical utility for this outcome (Moore 2008).

\section{Agreements and disagreements with other studies or reviews}

This review is in agreement with the earlier review (Edwards 1999b; Edwards 2000) for the outcomes they have in common.

\section{AUTHORS' CONCLUSIONS}

\section{Implications for practice}

This updated review confirms that aspirin is an effective analgesic for acute postoperative pain of moderate to severe intensity. The $600 / 650 \mathrm{mg}$ dose has comparable efficacy to the same dose of paracetamol, and a $1200 \mathrm{mg}$ gives a better response. However, even in these single dose studies, adverse events such as gastric irritation and nausea were more common with aspirin than placebo at higher does.

\section{Implications for research}

It is unlikely that further studies of this sort will be carried out for aspirin, and we have a sufficiently large body of evidence to be confident with the results for the $600 / 650 \mathrm{mg}$ dose. In many parts of the world, use of aspirin as an analgesic is falling because of its known gastrointestinal effects.

\section{ACKNOWLEDGEMENTS}

Jayne Edwards, Anna Oldman, Lesley A Smith, Sally L Collins, Dawn Carroll, Philip J Wiffen, Henry J McQuay, R Andrew Moore were authors on the original 1999 review. 


\section{R E F E R E N C E S}

\section{References to studies included in this review}

\section{Bloomfield 1967 \{published data only\}}

Bloomfield SS, Gaffney TE, Howett M. Comparative analgesic efficacy of chlorphenesin carbamate and acetylsalicylic acid after episiotomy. Anesthesia and Analgesia 1967;46(5):515-20.

\section{Boraks 1987 \{published data only\}}

Boraks S. Flurbiprofen in low dosage compared with metamizole sodium (dipyrone), acetylsalicylic acid and placebo in treatment of pain following dental extractions [Flurbiprofen em dose baixa comparado a dipirona, acido acetilsalicilico e placebo no tratamento da dor pos-extracao dentaria]. Arquivos Brasileiros de Medicina 1987;61(6):424-30.

\section{Breivik 1984 \{published data only\}}

Breivik H, Stenseth R, Apalseth K, Spilsberg AM. Piroxicam, acetylsalicylic acid and placebo for postoperative pain. Acta Anaesthesiologica Scandinavica 1984;28:37-9.

\section{Calimlim 1977 \{published data only\}}

Calimlim JF, Wardell WM, Davis HT, Lasagna L, Gillies AJ. Analgesic efficacy of an orally administered combination of pentazocine and aspirin. With observations on the use and statistical efficiency of GLOBAL subjective efficacy ratings. Clinical Pharmacology and Therapeutics 1977;21(1):34-43.

\section{Clark 1989 \{published data only\}}

* Clark MS, Lindenmuth JE, Silverstone LM, Fryer GE Jr. A double blind single dose evaluation of the relative analgesic efficacy and safety of carprofen in the treatment of postoperative pain after oral surgery. Oral Surgery Oral Medicine and Oral Pathology 1989;68(3):273-8.

Lindenmuth J, Clark M, Fryer GJ. Evaluation of the analgesic efficacy and safety of carprofen. Anesthesia Progress 1989;36(4-5):206-9.

\section{Cooper 1977 \{published data only\}}

Cooper SA, Needle SE, Kruger GO. Comparative analgesic potency of aspirin and ibuprofen. Journal of Oral Surgery 1977;35:898-903.

\section{Cooper 1979a \{published data only\}}

Cooper SA, Breen JF, Giuliani RL. Replicate studies comparing the relative efficacies of aspirin and indoprofen in oral surgery outpatients. Journal of Clinical Pharmacology 1979;19(2-3):151-9.

\section{Cooper 1982 \{published data only\}}

Cooper SA, Engel J, Ladov M, Precheur H, Rosenheck A, Rauch D. Analgesic efficacy of an ibuprofen-codeine combination. Pharmacotherapy 1982;2:162-7.

\section{Cooper 1983 \{published data only\}}

Cooper SA, Wagenberg B, Eskow R, Zissu J. Double blind evaluation of suprofen and aspirin in the treatment of periodontal pain. Pharmacology 1983;27(Suppl 1):23-30.

\section{Cooper 1986 \{published data only\}}

Cooper SA, Wagenberg B, Zissu J, Kruger GO, Reynolds DC, Gallegos LT, et al. The analgesic efficacy of suprofen in periodontal and oral surgical pain. Pharmacotherapy 1986;6(5):267-76.

\section{Cooper 1988 \{published data only\}}

Cooper SA, Mardirossian G, Milles M. Analgesic relative potency assay comparing flurbiprofen 50,100 , and $150 \mathrm{mg}$, aspirin 600 $\mathrm{mg}$, and placebo in postsurgical dental pain. Clinical Journal of Pain 1988;4:175-81.

\section{Cooper 1991 \{published data only\}}

Cooper SA, Hutton C, Reynolds DC, Gallegos LT, Allen C, Marriott JG, et al. Dose-response analgesic activity of meclofenamate sodium in dental pain. Advances in Therapy 1991;8(4):157-65.

\section{Cooper 1992 \{published data only\}}

Cooper SA, Itkin A, Zweig B. Comparison of oxaprozin, aspirin, and placebo in a dental impaction pain model. Advances in Therapy 1992;9(3):184-94.

\section{Coutinho 1976 \{published data only\}}

Coutinho A, Bonelli J, Nanci de Carvelho P. A double-blind comparative study of the analgesic effects of fenbufen, codeine, aspirin, propoxyphene and placebo. Current Therapeutic Research 1976;19:58-65.

\section{Desjardins 1984 \{published data only\}}

Desjardins PJ, Cooper SA, Gallegos TL, Allwein JB, Reynolds DC, Kruger $\mathrm{GO}$, et al. The relative analgesic efficacy of propiram fumarate, codeine, aspirin, and placebo in post impaction dental pain. Journal of Clinical Pharmacology 1984;24(1):35-42.

\section{De Vroey 1977 \{published data only\}}

De Vroey P. A double blind comparison of diflunisal and aspirin in the treatment of post operative pain after episiotomy. Current Medical Research and Opinion 1978;5(7):544-7.

* DeVroey P, Steelman SL, Caudron J, Verhaest L, Besselaar GH, Buntinx A. A double-blind, placebo-controlled, single-dose study comparing three-dose levels of diflunisal with aspirin and placebo in patients with pain due to episiotomy. Acta Therapeutica 1977;3:205-15.

\section{Fliedner 1984 \{published data only\}}

Fliedner L, Levsky M, Kechejian H, Berger J, Gaston G, Hutton CE. Analgesia with etodolac in oral postsurgical pain. Current Therapeutic Research 1984;36(1):33-45.

Forbes 1980 \{published data only\}

Forbes JA, White RW, White EH, Hughes MK. An evaluation of the analgesic efficacy of proquazone and aspirin in postoperative dental pain. Journal of Clinical Pharmacology 1980;20(7):465-74.

\section{Forbes 1982 \{published data only\}}

Beaver WT, Forbes JA, Shackleford RW. A method for the 12hour evaluation of analgesic efficacy in outpatients with 
postoperative oral surgery pain. Three studies of diflunisal. Pharmacotherapy 1983;3(2):23S-37S.

* Forbes JA, Calderazzo JP, Bowser MW, Foor VM, Shackleford RW, Beaver WT. A 12 hour evaluation of the analgesic efficacy of diflunisal, aspirin, and placebo in postoperative dental pain. Journal of Clinical Pharmacology 1982;22(2-3):89-96.

\section{Forbes 1983 \{published data only\}}

Forbes JA, Butterworth GA, Burchfield WH, Beaver WT, Shackleford RW. A 12 hour evaluation of the analgesic efficacy of diflunisal, zomepirac sodium, aspirin, and placebo in postoperative oral surgery pain. Pharmacotherapy 1983;3(2):38S-46S.

Forbes 1984 \{published data only\}

Forbes J, Barkaszi B, Ragland R, Hankle J. Analgesic effect of fendosal, ibuprofen and aspirin in postoperative oral surgery pain. Pharmacotherapy 1984;4:385-91.

\section{Forbes 1986 \{published data only\}}

Forbes JA, Keller CK, Smith JW, Zeleznock JR, Sevelius H, Beaver WT. Analgesic effect of naproxen sodium, codeine, a naproxen codeine combination and aspirin on the postoperative pain of oral surgery. Pharmacotherapy 1986;6(5):211-8.

\section{Forbes 1989 \{published data only\}}

Forbes JA, Yorio CC, Selinger LR, Rosenmertz SK, Beaver WT. An evaluation of flurbiprofen, aspirin, and placebo in postoperative oral surgery pain. Pharmacotherapy 1989;9(2):66-73.

\section{Forbes 1990a \{published data only\}}

Forbes JA, Jones KF, Kehm CJ, Smith WK, Gongloff CM, Zeleznock JR, et al. Evaluation of aspirin, caffeine, and their combination in postoperative oral surgery pain. Pharmacotherapy 1990;10(6):387-93.

\section{Forbes 1990b \{published data only\}}

Forbes JA, Butterworth GA, Burchfield WH, Beaver WT. Evaluation of ketorolac, aspirin, and an acetaminophencodeine combination in postoperative oral surgery pain. Pharmacotherapy 1990;10(6):77S-93S.

Forbes 1991 \{published data only\}

Forbes J, Edquist I, Smith F, Schwartz M, Beaver W. Evaluation of bromfenac, aspirin, and ibuprofen in postoperative oral surgery pain. Pharmacotherapy 1991;11:64-70.

Forbes 1992 \{published data only\}

Forbes JA, Beaver WT, Jones KF, Edquist IA, Gongloff CM, Smith WK, et al. Analgesic efficacy of bromfenac, ibuprofen, and aspirin in postoperative oral surgery pain. Clinical Pharmacology and Therapeutics 1992;51(3):343-52.

\section{Frame 1986 \{published data only\}}

Frame J, Fisher S, Pickvance N, Skene A. A double blind placebo controlled comparison of three ibuprofen combinations and aspirin. British Journal of Oral and Maxillofacial Surgery 1986;24:122-9.

\section{Gaston 1984 \{published data only\}}

Gaston GW, Mallow RD, Frank JE. The efficacy of etodolac for patients with pain following oral surgery. Journal of Oral and Maxillofacial Surgery 1984;42(6):362-6.

Gaston 1986 \{published data only\}

Gaston GW, Mallow RD, Frank JE. Comparison of etodolac, aspirin and placebo for pain after oral surgery. Pharmacotherapy 1986;6(5):199-205.

\section{Herbertson 1994 \{published data only\}}

Herbertson R, Storey N. The comparative efficacy of diclofenac potassium, aspirin, and placebo in the treatment of patients with pain following gynecologic surgery. Today's Therapeutic Trends 1994;12(S1):33-45.

\section{Herrmann 1980a \{published data only\}}

Herrmann U, Laube W, Roth F, Schultheiss HR, Berger M, Schürmann $\mathrm{P}$, et al. Analgesic effect of fluproquazone in postoperative patients. Clinical Pharmacology and Therapeutics 1980;27(3):379-85.

\section{Herrmann 1980b \{published data only\}}

Herrmann U, Laube W, Roth F, Schultheiss HR, Berger M, Schürmann $P$, et al. Analgesic effect of fluproquazone in postoperative patients. Clinical Pharmacology and Therapeutics 1980;27(3):379-85

\section{Holland 1988 \{published data only\}}

Holland IS, Seymour RA, Ward Booth RP, Ord RA, Lim KL, Hoare RC. An evaluation of different doses of soluble aspirin and aspirin tablets in postoperative dental pain. British Journal of Clinical Pharmacology 1988;26(4):463-8.

Honig 1978 \{published data only\}

Honig WJ. The use of diflunisal in post operative pain: a report of double blind comparative trials in patients after meniscectomy. Current Medical Research and Opinion 1978;5(7):536-43.

* Honig WJ, Cremer CW, Manni JG. A single dose study comparing the analgesic effects of diflunisal, acetylsalicylic acid, and placebo in pain following meniscectomy. Journal of International Medical Research 1978;6(3):172-9.

\section{Jain 1985a \{published data only\}}

Jain AK, McMahon FG, Ryan JR, Smith GB. Analgesic efficacy of indoprofen in postpartum episiotomy pain. Current Therapeutic Research 1985;38(5):677-81.

Jain 1985b \{published data only\}

Jain AK, McMahon FG, Ryan JR. An analgesic study of indoprofen, aspirin and placebo in dental surgery patients. Current Therapeutic Research 1985;38(5):682-8.

\section{Jain 1986a \{published data only\}}

Jain AK, Hunley CC, Kuebel J, McMahon FG, Ryan JJ. Analgesic efficacy of amfenac, aspirin and placebo after extraction of impacted teeth. Pharmacotherapy 1986;6(5):236-40. 
Jain 1986b \{published data only\}

Jain A, Ryan J, McMahon F, Kuebel J, Walters P, Noveck C. Analgesic efficacy of low dose ibuprofen in dental extraction pain. Pharmacotherapy 1986;6:318-22.

\section{Kempf 1987 \{published data only\}}

Kempf K, Konzelman J, Schultz R, Turner J. Comparison of meclofenamate sodium with buffered aspirin and placebo for the relief of postoperative dental pain. Clinical Therapy 1987;9(6):594-601.

\section{Lehnert 1990 \{published data only\}}

Lehnert S, Reuther J, Wahl G, Brarthel K. The efficacy of paracetamol (Tylenol) and acetyl salicylic acid (aspirin) in treating postoperative pain [Wirksamkeit von paracetamol (tylenol) und acetylsalizylure (aspirin) bei postperativen schmerzen]. Deutsche zahnarztliche Zeitschrift 1990;45:23-6.

\section{London 1983a \{published data only\}}

London R, Sundaram G, Feldman S, Goldstein P. Episiotomy pain:efficacy and safety of fluproquazone compared to aspirin and placebo. International Journal of Gynaecology and Obstetrics 1983;21(3):251-5.

London 1983b \{published data only\}

London R, Sundaram G, Feldman S, Goldstein P. Aspirin in the treatment of episiotomy pain. Southern Medical Journal 1983;76(7):844-5.

\section{Mardirossian 1985 \{published data only\}}

Cooper SA, Mardirossian G. Comparison of flurbiprofen and aspirin in the relief of postsurgical pain using the dental pain model. American Journal of Medicine 1986;80(3A):36-40.

* Mardirossian G, Cooper S. Comparison of the analgesic efficacy of flurbiprofen and aspirin for postsurgical dental pain. Journal of Oral and Maxillofacial Surgery 1985;43(2):106-9.

\section{Markowitz 1985 \{published data only\}}

Markowitz N, Young S, Rohrer M, Turner J. Comparison of meclofenamate sodium with buffered aspirin and placebo in the treatment of postsurgical dental pain. Journal of Oral and Maxillofacial Surgery 1985;43(7):517-22.

\section{McQuay 1987 \{published data only\}}

McQuay HJ, Carroll D, Poppleton P, Summerfield RJ, Moore RA. Fluradoline and aspirin for orthopedic postoperative pain. Clinical Pharmacology and Therapeutics 1987;41(5):531-6.

\section{Mehlisch 1984 \{published data only\}}

Mehlisch DR, Frakes LA. A controlled comparative evaluation of acetaminophen and aspirin in the treatment of postoperative pain. Clinical Therapeutics 1984;7(1):89-97.

\section{Mehlisch 1990 \{published data only\}}

Mehlisch DR, Sterling WR, Mazza FA, Singer JM. A single dose study of the efficacy and safety of FS 205397 (250 mg or 500 $\mathrm{mg}$ ) versus aspirin and placebo in the treatment of postsurgery dental pain. Journal of Clinical Pharmacology 1990;30(9):815-23.

\section{Mehlisch 1994 \{published data only\}}

Mehlisch D, Brown P. Single-dose therapy with diclofenac potassium, aspirin, or placebo following dental impaction surgery. Today's Therapeutic Trends 1994;12(S1):15-31.

Nelson 1985 \{published data only\}

Nelson SL, Bergman SA. Relief of dental surgery pain: a controlled 12 hour comparison of etodolac, aspirin, and placebo. Anesthesia Progress 1985;32(4):151-6.

Nelson 1994a \{published data only\}

Nelson SL, Brahim JS, Korn SH, Greene SS, Suchower LJ. Comparison of single-dose ibuprofen lysine, acetylsalicylic acid, and placebo for moderate-to-severe postoperative dental pain. Clinical Therapeutics 1994;16(3):458-65.

\section{Nelson 1994b \{published data only\}}

Nelson S, Brahim J. An evaluation of the analgesic efficacy of diclofenac potassium, aspirin, and placebo in postoperative dental pain. Today's Therapeutic Trends 1994;12(S1):3-14.

\section{Olsen 1997 \{published data only\}}

Olsen NZ, Sunshine A, Zighelboim I, DeCastro A. Onset and duration of analgesia of diclofenac potassium in the treatment of postepisiotomy pain. American Journal of Therapeutics 1997;4:239-46.

\section{Or 1988 \{published data only\}}

Or S, Bozkurt A. Analgesic effect of aspirin, mefenamic acid and their combination in post operative oral surgery pain. Journal of International Medical Research 1988;16(3):167-72.

Parkhouse 1969 \{published data only\}

Parkhouse J, Heppenstall C, Smith E, Wright V. An attempt to evaluate a rapidly acting oral analgesic. Canadian Medical Association Journal 1969;100:1057-8.

Patel 1991 \{published data only\}

Patel A, Skelly AM, Kohn H, Preiskel HW. Double-blind placebocontrolled comparison of the analgesic effects of single doses of lornoxicam and aspirin in patients with postoperative dental pain. British Dental Journal 1991;170(8):295-9.

Rowe 1985 \{published data only\}

Rowe NH, Aseltine LF, Turner JL. Control of pain with meclofenamate sodium following removal of an impacted molar. Oral Surgery Oral Medicine and Oral Pathology 1985;59(5):446-8.

\section{Seymour 1986 \{published data only\}}

Seymour RA, Williams FM, Luyk NM, Boyle MA, Whitfield PM, Nicholson E, et al. Comparative efficacy of soluble aspirin and aspirin tablets in postoperative dental pain. European Journal of Clinical Pharmacology 1986;30(4):495-8.

\section{Seymour 1992 \{published data only\}}

Seymour RA, Weldon M, Kelly P, Nicholson E, Hawkesford JE. An evaluation of buffered aspirin and aspirin tablets in postoperative pain after third molar surgery. British Journal of Clinical Pharmacology 1992;33(4):395-9. 
Seymour 2003 \{published data only\}

Seymour RA, Hawkesford JE, Sykes J, Stillings M, Hill CM. An investigation into the comparative efficacy of soluble aspirin and solid paracetamol in postoperative pain after third molar surgery. British Dental Journal 2003;194(3):153-7.

Sunshine 1983a \{published data only\}

Sunshine A, Marrero I, Olson NZ, Laska EM, McCormick N. Oral analgesic efficacy of suprofen compared to aspirin, aspirin plus codeine, and placebo in patients with postoperative dental pain. Pharmacology 1983;27(1):31-40.

Sunshine 1983b \{published data only\}

Sunshine A, Olson NZ, Laska EM, Zighelboim I, De Castro A, De Sarrazin C. Analgesic effect of graded doses of flurbiprofen in post episiotomy pain. Pharmacotherapy 1983;3(3):177-81.

Sunshine 1983c \{published data only\}

Sunshine A, Olson N, Laska E, Zighelboim I, De Castro A, De Sarrazin C. Ibuprofen, zomepirac, aspirin, and placebo in the relief of postepisiotomy pain. Clinical Pharmacological Therapeutics 1983;34(2):254-8.

\section{Sunshine 1988 \{published data only\}}

Sunshine A, Roure C, Colon A, Olson NZ, Gonzalez L, Siegel C, et al. Analgesic efficacy of piroxicam in the treatment of postoperative pain. American Journal of Medicine 1988;84(5A):16-22.

\section{Wang 1982 \{published data only\}}

Wang RIH, Johnson RP, Lee JCM, Waite EM. The oral analgesic efficacy of bicifadine hydrochloride in postoperative pain. Journal of Clinical Pharmacology 1982;22(4):160-4.

\section{Winter 1983a \{published data only\}}

Winter LJ, Post A. Double blind comparison of single oral doses of oxaprozin, aspirin, and placebo for relief of post operative oral surgery pain. Journal of International Medical Research 1983;11(5):308-14

\section{Winter 1983b \{published data only\}}

Winter LJr, Appleby F, Ciccone PE, Pigeon JG. A comparative study of an acetaminophen analgesic combination and aspirin in the treatment of post-operative oral surgery pain. Current Therapeutic Research 1983;33(2):200-13.

\section{References to studies excluded from this review}

\section{Ahlstrom 1968 \{published data only\}}

Ahlstrom U, Lantz B. A comparison between dextropropoxyphene hydrochloride and acetylsalicylic acid as analgesics after oral surgery. Odontologisk Revy 1968;19:55-63.

\section{Ahlstrom 1974 \{published data only\}}

Ahlstrom U, Kahnberg KE, Roos BE. Pentazocine and aspirin for pain following oral surgery. Acta Pharmacologica et Toxicologica (Copenhagen) 1974;35(4):325-36.

\section{Antonsson 1985 \{published data only\}}

Antonsson J, Carlstedt A, Lofgren B, Solhaug JH, Spangen L. The analgesic effects of acetylsalicylic acid combined with codeine versus given separately to patients with postoperative pain. Opmear 1985;30(3):90-2.

\section{Aromaa 1978 \{published data only\}}

Aromaa U, Asp K. A comparison of naproxen, indomethacin and acetylsalicylic acid in pain after varicose vein surgery. Journal of International Medical Research 1978;6(2):152-6.

\section{Barrenechea 1981 \{published data only\}}

Barrenechea Arana J, Berrazueta Fernandez M, Pascual Borrego A, Castillo EscAndon R. Diflunisal in the treatment of post operative pain in oral surgery. Double blind study [Diflunisal en el tratamiento del dolor postoperatorio en cirugia oral. Estudio doble ciego]. Revista Espanola de Estomatologia 1981;29(3):171-8.

\section{Bella 1987 \{published data only\}}

Bella G, Russo S, Messina G. Clinical trial of a new non steroidal analgesic (diflunisal) in oral surgery [Ricerche di sperimentazione clinica su un nuovo analgesico non steroideo (diflunisal) in chirurgia orale]. Minerva Stomatologica 1987;36(4):297-300.

\section{Bhounsule 1990 \{published data only\}}

Bhounsule SA, Nevreker PR, Agshikar NV, Pal MN, Dhume VG. A comparison of four analgesics in post-episiotomy pain. Indian Journal of Physiology and Pharmacology 1990;34(1):34-8.

Bloomfield 1974 \{published data only\}

Bloomfield SS, Barden TP, Mitchell J. Comparative efficacy of ibuprofen and aspirin in episiotomy pain. Clinical Pharmacology and Therapeutics 1974;15(6):565-70.

\section{Bloomfield 1976 \{published data only\}}

Bloomfield SS, Barden TP, Mitchell J. Aspirin and codeine in two postpartum pain models. Clinical Pharmacology and Therapeutics 1976;20(4):499-503.

\section{Boerlin 1986 \{published data only\}}

Boerlin V, Maeglin B, Hagler W, Kuhn M, Nuesch E. Analgesic activity of propyphenazone in patients with pain following oral surgery. European Journal of Clinical Pharmacology 1986;31(2):127-31.

\section{Burguet 1989 \{published data only\}}

Burguet J, Kupperberg E. Double-blind therapeutic study comparing tiaprofenic acid and acetylsalicylic acid in dentistry. Journal of Drug Development 1989;2(2):115-7.

\section{Campos 1980 \{published data only\}}

Campos VM, Solis EL. The analgesic and hypothermic effects of nefopam, morphine, aspirin, diphenhydramine, and placebo. Journal of Clinical Pharmacology 1980;20(1):42-9.

Capuano 1990 \{published data only\}

Capuano A, Valerio P, Bonucci I, Rosadini F. Use of NSAIDs in dentistry: double blind controlled study of Diflunisal versus ASA [Uso dei fans in odontostomatologia: studio controllato 
in doppio cieco Diflunisal versus ASA]. Giornale di Anestesia Stomatologica 1990;19(2):27-36.

\section{Carstens 1987 \{published data only\}}

Carstens M, Ligueros O, Lobo R, Pauz M, Gallardo F. Comparative double blind study of the analgesic and anti inflammatory activity of glucamethacin (Indicin), aspirin and placebo in oral surgery [Estudio comparativo doble-ciego de la actividad analgesica y antiiflamatoria de la glucametacina (indicin), aspirina y placebo en cirugia oral]. Odontologia Chilena 1987;35(1):31-9.

\section{Cooper 1976 \{published data only\}}

Cooper SA, Beaver WT. A model to evaluate mild analgesics in oral surgery outpatients. Clinical Pharmacology and Therapeutics 1976;20(2):241-50.

\section{Cooper 1979b \{published data only\}}

Cooper SA, Breen JF, Giuliani RL. Replicate studies comparing the relative efficacies of aspirin and indoprofen in oral surgery outpatients. Journal of Clinical Pharmacology 1979;19(2-3):151-9.

\section{Cooper 1980a \{published data only\}}

Cooper SA, Reynolds DC, Kruger GO, Gottlieb S. An analgesic relative potency assay comparing zomepirac sodium and aspirin. Journal of Clinical Pharmacology 1980;20(2-3):98-106.

\section{Cooper 1980b \{published data only\}}

Cooper S. Efficacy of zomepirac in oral surgical pain. Journal of Clinical Pharmacology 1980;20(4):230-42.

\section{Cordero 1985 \{published data only\}}

Cordero R. A comparative study of Lagundi and aspirin as analgesics for post-extraction pain. Journal of the Philippine Dental Association 1985;35(1):15-8.

\section{Dahl 1985 \{published data only\}}

Dahl E, Feldmann G, Jonsson E. Acetylsalicylic acid compared with acetylsalicylic acid plus codeine as postoperative analgesics after removal of impacted mandibular third molars. Swedish Dental Journal 1985;9(5):207-12.

\section{Desjardins 1983 \{published data only\}}

Desjardins PJ, Cooper SA, Ruderman CM, Gallegos LT, Reynolds DC, Kruger GO. The effects of fendosal, aspirin and placebo on postoperative dental pain. A dose ranging and efficacy study. Pharmacotherapy 1983;3(1):52-7.

\section{Di Blasi 1980a \{published data only\}}

Di Blasi F, Gnudi A. Use of floctafenine for dental pain of adults and children: a controlled study 1 [Impiego della floctafenina nei dolori odontostomatologici degli adulti e dei bambini:studio controllato - Prima parte]. Minerva Stomatologica 1980;29(4):265-80.

\section{Di Blasi 1980b \{published data only\}}

Di Blasi F, Gnudi A. Use of floctafenine in toothaches in adults and children: a controlled study II [Impiego della floctafenina nei dolori odontostomatologici degli adulti e dei bambini (studio controllato). Seconda parte]. Minerva Stomatologica 1980;29(5):345-58

Feldmeier 1982 \{published data only\}

Feldmeier $C$. The analgesic effect of carprofen in acute pain: results of two clinical studies. European Journal of Rheumatology and Inflammation 1982;5(4):522-6.

Fink 1978 \{published data only\}

Fink S, Nielsen KO. Comparison of a new analgesic, rimazolium with acetylsalicylic acid and placebo in postoperative pain. A randomised clinical trial. Current Therapeutic Research 1978;24:900-4.

Fleiss 1979 \{published data only\}

Fleiss JL, Chilton NW, Wallenstein S. Ridit analysis in dental clinical studies. Journal of Dental Research 1979;58(11):2080-4.

Friedrich 1983 \{published data only\}

Friedrich E. A comparison of etodolac (Ultradol) with aspirin and placebo in patients with episiotomy pain. Current Therapeutic Research 1983;33(1):100-7.

Fuccella 1977 \{published data only\} Fuccella LM, Corvi G, Gorini F, Mandelli V, Mascellani G, Nobili F, et al. Application of nonparametric procedure for bioassay data to the evaluation of analgesics in man. Journal of Clinical Pharmacology 1977;17(4):177-84.

Gallardo 1982 \{published data only\}

Gallardo F, Rossi E, Cisscutti V. Analgesic efficacy of ketoprofen on postoperative pain following periodontal surgery. IRCS Medical Science 1982;10(12):1036-7.

Gallardo 1984 \{published data only\} Gallardo F, Rossi VE, Lobos TM. Indoprofen and aspirin for the control of postoperative pain following peridontal surgery. Acta Odontologica Latinoamericana 1984;1:87-91.

\section{Gallardo 1990 \{published data only\}}

Gallardo F, Carstens M, Ayarza M. Analgesic and anti inflammatory effects of glucamethacin (a nonsteroidal anti inflammatory analgesic) after the removal of impacted third molars. Oral Surgery, Oral Medicine and Oral Pathology 1990;69(2):157-60.

Gallardo 1992 \{published data only\} Gallardo F, Rossi E. Effects of sodium meclofenamate on postoperative pain following periodontal surgery. Journal of Periodontology 1992;63(3):166-8.

\section{Gammelgaard 1981 \{published data only\}}

Gammelgaard NP, Juul A, Larsen K, Ohrt Mikkelsen B. Comparison of a new analgesic, Ro 11-4337, with acetylsalicylic acid and placebo in pain following tonsillectomy: a randomized clinical trial. Current Therapeutic Research 1981;30(2):151-5.

\section{Giglio 1984 \{published data only\}}

Giglio JA, Campbell RL. The prophylactic use of flurbiprofen to prevent post-extraction dental pain. Anesthesia Progress 1984;31(2):74-6. 
Giles 1986 \{published data only\}

Giles AD, Hill CM, Shepherd JP, Stewart DJ, Pickvance NJ. A single dose assessment of an ibuprofen/codeine combination in postoperative dental pain. International Journal of Oral and Maxillofacial Surgery 1986;15(6):727-32.

\section{Green 1978 \{published data only\}}

Green AE. A clinical trial of pentazocine and aspirin following minor oral surgery. British Dental Journal 1976;141(8):247-50.

\section{Grippaudo 1981 \{published data only\}}

Grippaudo G, Amato R, Giordano A, Sarzani R, Segatore I, Addessi G. Analgesic treatment of trigeminal nerve pain following dental extractions [Terapia analgesica nel polore postestrattivo dell incluso]. Clin Europ 1981;20(4):661-6.

\section{Happonen 1987 \{published data only\}}

Happonen RP, Oksala E, Ylipaavalniemi P. A combination of acetylsalicylic acid and codeine phosphate versus acetylsalicylic acid as postoperative analgesics after mandibular third molar surgery. Proceedings of the Finnish Dental Society 1987;83(1):32-5

\section{Heimdahl 1979 \{published data only\}}

Heimdahl A, Dahlstrom H. A double blind single dose comparison between two analgesics, rimazolium and acetylsalicylic acid in oral surgery outpatients. Swedish Dental Journal 1979;3(2):57-61.

\section{Henrikson 1979 \{published data only\}}

Henrikson PA, Tjernberg A, Ahlstrom U, Peterson LE. Analgesic efficacy and safety of Fenbufen following surgical removal of a lower wisdom tooth: a comparison with acetylsalicylic acid and placebo. Journal of International Medical Research 1979;7(2):107-16.

\section{Hepso 1976 \{published data only\}}

Hepso HU, Lokken P, Bjornson J, Godal HC. Double blind crossover study of the effect of acetylsalicylic acid on bleeding and post-operative course after bilateral oral surgery. European Journal of Clinical Pharmacology 1976;10:217-25.

\section{Herrmann 1980c \{published data only\}}

Herrmann U, Laube W, Roth F, Schultheiss HR, Berger M, Schürmann $\mathrm{P}$, et al. Analgesic effect of fluproquazone in postoperative patients. Clinical Pharmacology and Therapeutics 1980;27(3):379-85.

\section{Herrmann 1980d \{published data only\}}

Herrmann U, Laube W, Roth F, Schultheiss HR, Berger M, Schürmann $\mathrm{P}$, et al. Analgesic effect of fluproquazone in postoperative patients. Clinical Pharmacology and Therapeutics 1980;27(3):379-85

\section{Hill 1969 \{published data only\}}

Hill RC, Turner P. Importance of initial pain in post operative assessment of analgesic drugs. Journal of Clinical Pharmacology and the Journal of New Drugs 1969;9(5):321-7.

\section{Hutton 1983 \{published data only\}}

Hutton CE. The effectiveness of 100 and $200 \mathrm{mg}$ etodolac (Ultradol), aspirin, and placebo in patients with pain following oral surgery. Oral Surgery, Oral Medicine and Oral Pathology 1983;56(6):575-80.

Ihalainen 1980 \{published data only\}

Ihalainen U, Rissanen $\mathrm{H}$, Oikarinen VJ. The efficacy and tolerability of diflunisal and ASA in the relief of postoperative pain in oral surgery. Proceedings of the Finnish Dental Society 1980;76(5-6):262-6.

Irwin 1984 \{published data only\} Irwin BC, Acharya KB. A comparative study of benzydamine hydrochloride $0.15 \% \mathrm{w} / \mathrm{v}$ ('Difflam' oral rinse) and acetyl salicylic acid as analgesics following tonsillectomy. Journal of International Medical Research 1984;12(3):216-8.

Izquierdo 1995 \{published data only\}

Izquierdo E, Fabregas N, Valero R, Salvador L, Soley R, Nalda MA. Postoperative analgesia in herniated disk surgery. Comparative study of diclofenac, lysine acetylsalicylate and ketorolac [Analgesia postoperatoria en la cirugia de hernia discal. Estudio comparativo de diclofenaco, acetilsalicilato de lisina y ketorolaco]. Revista Espanola de Anestesiologia y Reanimacion 1995;42(8):316-9.

\section{Jain 1978a \{published data only\}} Jain AK, McMahon FG, Ryan JR, Unger D, Richard W. Aspirin and aspirin-caffeine in postpartum pain relief. Clinical Pharmacology and Therapeutics 1978;24(1):69-75

Jain 1978b \{published data only\} Jain AK, McMahon FG, Ryan JR. Piroxicam, a novel analgesic in postpartum pain. European Journal of Rheumatology and Inflammation 1978;1(3):356-9.

\section{Joubert 1982 \{published data only\}} Joubert L, Mullane JF, Merlo M, Martel R, Arnold J, Rolly G, et al. Clinical pharmacological profile of Ultradol registered, a new nonsteroidal anti-inflammatory drug. Current Therapeutic Research 1982;32(1):74-88.

\section{Kamiyama 1980 \{published data only\}}

Kamiyama Y, Takahashi Y, Hagiwara H, Horiuchi H, Tokusu S. Effects of flurbiprofen (FP 70) on pain in periodontics: double blind methods in comparison with aspirin. Shikai Tenbo 1980;56(5):849-58

\section{Kantor 1965 \{published data only\}}

Kantor TG, Sunshine A, Laska E, Meisner M, Hopper M. Oral analgesic studies: pentazocine hydrochloride, codeine, aspirin, and placebo and their influence on response to placebo. Clinical Pharmacology and Therapeutics 1965;7(4):447-54.

\section{Kristensen 1986 \{published data only\}}

Kristensen S, Tveteras K, Outzen K, Poulsen H. Treatment of pain after tonsillectomy. Comparison between naproxen (Naprosyn) and acetylsalicylic acid (Kalcatyl) [Smertebehandling efter tonsillektomi. En sammenlignende 
undersogelse af naproxen (Naprosyn) og acetylsalicylsyre (Kalcatyl)]. Ugeskrift for Laeger 1986;148(44):2832-5.

Kristensen 1988 \{published data only\}

Kristensen S, Tveteraas K, Hein P, Poulsen H, Outzen K. Relief of pain and trismus in patients treated with naproxen or acetylsalicylic acid after tonsillectomy. Journal of Laryngology and Otology 1988;102(1):39-42.

\section{Lamphier 1974 \{published data only\}}

Lamphier T, Rodriguez A, Richards D. Double blind study of the analgesic effect of ethoheptazine aspirin. Current Therapeutic Research 1974;16(7):718-33.

Lobo 1983 \{published data only\}

Lobo R, Gallardo F, Henriquez E, Iriarte E. Analgesic activity of ketoprofen in post-operative oral surgery pain. IRCS Medical Science 1983;11(7):639-40.

\section{Maeglin 1979 \{published data only\}}

Maeglin B, Hagler W, Kuhn M, von Graffenried B, Nüesch E. Analgesic effect of fluproquazone in oral surgery outpatients. Current Therapeutic Research 1979;26(3):284-94.

\section{Mahler 1976 \{published data only\}}

Mahler D, Forrest WJ, Brown C, Shroff PF, Gordon HE, Brown BW Jr, et al. Assay of aspirin and naproxen analgesia. Clinical Pharmacology and Therapeutics 1976;19(1):18-23.

\section{Mandujano \{published data only\}}

Mandujano VM. Comparative study of the floctafenina and acid acetisalicilo in a cancer services [Estudio comparativo del floctafenina y acido acetisalicilo en un servico ocorinolaringolgia]. Investigation Medico International [Date not given];3/6:379.

\section{Mehta 1986 \{published data only\}}

Mehta SD. A randomized double-blind placebo-controlled study of dipyrone and aspirin in post-operative orthopaedic patients. Journal of International Medical Research 1986;14:63-6.

\section{Mitchell 1985 \{published data only\}}

Mitchell DA, Ward BP, Seymour RA. A comparative study of the efficacy of aspirin and an ibuprofen/codeine combination in patients treated pre operatively with methylprednisolone acetate. British Dental Journal 1985;159(3):78-81.

\section{Mukherjee 1980 \{published data only\}}

Mukherjee S, Sood S. A controlled evaluation of orally administered aspirin, dipyrone and placebo in patients with post operative pain. Current Medical Research and Opinion 1980;6(9):619-23.

\section{Okun 1979 \{published data only\}}

Okun R, Green J, Shackleford R. An analgesic comparison study of indoprofen versus aspirin and placebo in surgical pain. Journal of Clinical Pharmacology 1979;19(8-9 Pt 1):487-92.

\section{Okun 1982 \{published data only\}}

Okun R. Evaluation of the analgesic effect of Fendosal in patients with postpartum uterine cramp or episiotomy pain. Current Therapeutic Research 1982;31(1):65-73.

\section{Or 1985 \{published data only\}}

Or S, Bozkurt A. Evaluation of the analgesic effects of various aspirin combinations in oral surgery [Agiz cerrahisi pratigindeki postoperatif agrida bazi aspirin kombinasyonlarinin analjezik etikilerinin arastirilmasi]. Ankara Universitesi Dis Hekimligi Fakultesi Dergisi 1985;12(2):321-32.

Ormiston 1981 \{published data only\}

Ormiston MC, Vaughton KC, Thornton EJ, La Coste JJ, Milroy E. The comparative effectiveness of tiaprofenic acid and aspirin in the treatment of post-prostatectomy pain. British Journal of Clinical Practice 1981;35(10):360-2.

\section{Parker 1986 \{published data only\}}

Parker D, Gibbin K, Noyelle R. Syrup formulations for post tonsillectomy analgesia: a double blind study comparing ibuprofen, aspirin and placebo. Journal of Laryngology and Otology 1986;100(9):1055-60.

\section{Parkhouse 1967a \{published data only\}}

Parkhouse J, Collie JA, Wood V. A study of aspirin and nepenthe. British Journal of Anaesthesia 1967;39:38-49.

Parkhouse 1967b \{published data only\}

Parkhouse J, Hallinon P. A comparison of aspirin and paracetamol. British Journal of Anaesthesia 1967;39:146-54.

Parkhouse 1968 \{published data only\}

Parkhouse J, Rees-Lewis M, Skolinik M, Peters H. The clinical dose response to aspirin. British Journal of Anaesthesia 1968;40(6):433-41.

\section{Perotti 1984 \{published data only\}}

Perotti R. Diflunisal and acetylsalicylic acid: a double blind study of their effect on post-extraction pain [Diflunisal ed ASA: studio in doppio cieco, sull'azione del dolore post-estrattivo]. Minerva Stomatologica 1984;33(4):645-50.

Reines 1986 \{published data only\}

Reines HD, Hunt P, Rambo W, Loadholt CB. Oral ciramadol: a new analgesic for postoperative pain. Journal of Clinical Pharmacology 1986;26(2):111-4.

\section{Rowe 1981 \{published data only\}}

Rowe N, Cudmore C, Turner J. Control of pain by mefenamic acid following removal of impacted molar. A double blind, placebo controlled study. Oral Surgery, Oral Medicine and Oral Pathology 1981;51(6):575-80.

Rye 1978 \{published data only\}

Rye L, Siegel S. A study of factors influencing the qualitative response and/or the time interval of response to mild analgesics for postoperative pain. Georgetown Dental Journal 1978;62(2):36-41. 
Sechzer 1977 \{published data only\}

Sechzer P. Evaluation of fenoprofen as a postoperative analgesic. Current Therapeutic Research 1977;21(2):137-48.

\section{Seymour 1982 \{published data only\}}

Seymour RA, Rawlins MD. Efficacy and pharmacokinetics of aspirin in post operative dental pain. British Journal of Clinical Pharmacology 1982;13(6):807-10.

\section{Seymour 1983a \{published data only\}}

Seymour RA, Blair GS, Wyatt FAR. Post-operative dental pain and analgesic efficacy. British Journal of Oral Surgery 1983;21:298-303.

\section{Seymour 1983b \{published data only\}}

Seymour RA. Analgesic efficacy and plasma concentration of three analgesics in pain after lower third molar removal. SAAD Digest 1983;5(7):172-88.

\section{Seymour 1984 \{published data only\}}

Seymour RA, Williams FM, Ward A, Rawlins MD. Aspirin metabolism and efficacy in postoperative dental pain. British Journal of Clinical Pharmacology 1984;17(6):697-701.

\section{Sindet 1986 \{published data only\}}

Sindet PS, Petersen J, Gotzsche P, Christensen H. A double blind, randomized study of naproxen and acetylsalicylic acid after surgical removal of impacted lower third molars. International Journal of Oral and Maxillofacial Surgery 1986;15(4):389-94.

\section{Skjelbred 1977 \{published data only\}}

Skjelbred P, Album B, Lokken P. Acetylsalicylic acid vs paracetamol:effects on postoperative course. European Journal of Clinical Pharmacology 1977;12:257-64.

\section{Skjelbred 1984 \{published data only\}}

Skjelbred P. The effects of acetylsalicylic acid on swelling, pain and other events after surgery. British Journal of Clinical Pharmacology 1984;17(4):379-84.

\section{Slatis 1980 \{published data only\}}

Slatis P, Janhunen L, Quiding H. Multiple dose evaluation of analgesics, a comparison between two dextropropoxyphene compounds and acetylsalicylic acid in pain following meniscectomy. Current Therapeutic Research 1980;27:595-600.

\section{Spivach 1984 \{published data only\}}

Spivach A, Zamborlini F, Piccoli-Briganti F. Appraisal of the activity of one analgesic and tolerability of a drug of cecita association a controlled clinical study [Valutazione dell'attivita analgescia e della tollerabilita di un farmaco di associazione studio clinico controllato in doppia cecita]. Archivo Di Medicina Internationali 1984;36(3):151-65.

\section{Sunshine 1975 \{published data only\}}

Sunshine A. Analgesic value of fenbufen in postoperative patients. A comparative oral analgesic study of fenbufen, aspirin, and placebo. Journal of Clinical Pharmacology 1975;15(8-9):591-7.

\section{Sunshine 1978a \{published data only\}}

Sunshine A, Slafta J, Gruber CJr. A comparative analgesic study of propoxyphene, fenoprofen, the combination of propoxyphene and fenoprofen, aspirin, and placebo. Journal of Clinical Pharmacology 1978;18(11-12):556-63.

Sunshine 1978b \{published data only\}

Sunshine A, Laska E, Slafta J. Oral nefopam and aspirin. Clinical Pharmacology and Therapeutics 1978;24(5):555-9.

\section{Sunshine 1986 \{published data only\}}

Sunshine A, Zighelboim I, Laska E, Siegel C, Olson NZ, De Castro A. A double blind, parallel comparison of ketoprofen, aspirin, and placebo in patients with postpartum pain. Journal of Clinical Pharmacology 1986;26(8):706-11.

\section{Sveen 1975 \{published data only\}}

Sveen K, Gilhuus MO. Paracetamol/codeine in relieving pain following removal of impacted mandibular third molars. International Journal of Oral Surgery 1975;4(6):258-66.

\section{Szmyd 1959 \{published data only\}}

Szmyd L, McCall CM, Porreca AL. Aspirin and placebo in oral surgery. Journal of the American Dental Association 1959;59:84-7.

\section{Todorovic 1982 \{published data only\}}

Todorovic L, Petrovic V, Kafedziska V. Clinical investigation of analgesic and anti inflammatory effects of niflumic acid following oral surgery [Klinicka ispitivanja analgetskog i antiinflamatornog efekta niflumicne kiseline posle oralno-hirurskih intervencija]. Stomatoloski Glasnik Srbije 1982;29(5):325-30.

\section{Trop 1983 \{published data only\}}

Trop D, Nucci C, Elie R, Gareau J. Double-blind comparative evaluation of tiaprofenic acid (Surgam ${ }^{\circledR}$ ) versus acetylsalicylic acid (ASA) in relieving pain following episiotomy. Current Therapeutic Research 1983;34(2I):274-9.

Vaidya 1974 \{published data only\}

Vaidya A, Sheth M, Manghani K, Shroff P, Vora K, Sheth U. Double blind trial of mefenamic acid, aspirin and placebo in patients with post-operative pain. Indian Journal of Medical Sciences 1974;28(12):532-6

\section{Versichelen 1982 \{published data only\}}

Versichelen L, Bilsback P, Rolly G, Merlo M, Joubert L. Etodolac in postsurgical pain: a double blind dose ranging efficacy study with aspirin and placebo. International Journal of Clinical Pharmacology Therapeutics and Toxicology 1982;20(5):236-9.

\section{Von Graffenried 1980 \{published data only\}}

Von Graffenried B, Nuesch E, Maeglin B, Hagler W, Kuhn M. Assessment of analgesics in dental surgery outpatients. European Journal of Clinical Pharmacology 1980;18(6):479-82.

Walker 1960 \{published data only\}

Walker DE, Grimm DH, Way EL. An evaluation of the analgesic properties of a salicylamide derivative in comparison with 
a placebo and aspirin. Oral Surgery, Oral Medicine and Oral Pathology 1960;13(10):1214-7.

Wang 1979 \{published data only\}

Wang RI, Waite EM. The clinical analgesic efficacy of oral nefopam hydrochloride. Journal of Clinical Pharmacology 1979;19(7):395-402.

\section{Wilkinson 1960 \{published data only\}}

Wilkinson FC, Howe GL. The relative values of 'Antidol' and calcium aspirin as an analgesic. Practitioner 1960;185:316-20.

\section{Winter 1978 \{published data only\}}

Winter LJ, Bass E, Recant B, Cahaly J. Analgesic activity of ibuprofen (Motrin) in postoperative oral surgical pain. Oral Surgery, Oral Medicine and Oral Pathology 1978;45:159-66.

\section{Wojcicki 1977 \{published data only\}}

Wojcicki J, Samochowiec L, Lawczynski L, Szwed G, Olszewska M. A double blind comparative evaluation of aspirin, paracetamol and paracetamol + caffeine (Finimal) for their analgesic effectiveness. Archivum Immunologiae et Therapiae Experimentalis 1977;25(2):175-9.

\section{Zederfeldt 1977 \{published data only\}}

Zederfeldt B, Borg I, Haeger K. Efficacy and tolerance of Flunixin ( $\mathrm{SCH} 14714$ ) in the treatment of postoperative pain, with observations on the methodology of postoperative pain studies. British Journal of Anaesthetics 1977;49(5):467-71.

\section{Additional references}

\section{Barden 2004}

Barden J, Edwards JE, McQuay HJ, Wiffen PJ. Relative efficacy of oral analgesics after third molar extraction. British Dental Journal 2004;197(7):407-11.

\section{Clarke 2009}

Clarke R, Derry S, Moore RA, McQuay HJ. Single dose oral etoricoxib for acute postoperative pain in adults. Cochrane Database of Systematic Reviews 2009, Issue 2. [DOI: 10.1002/14651858.CD004309.pub2]

\section{Collins 1997}

Collins SL, Moore RA, McQuay HJ. The visual analogue pain intensity scale: what is moderate pain in millimetres?. Pain 1997;72:95-7.

\section{Collins 2001}

Collins SL, Edwards J, Moore RA, Smith LA, McQuay HJ. Seeking a simple measure of analgesia for mega-trials: is a single global assessment good enough?. Pain 2001;91(1-2):189-94.

\section{Cook 1995}

Cook RJ, Sackett DL. The number needed to treat: a clinically useful measure of treatment effect. BMJ 1995;310:452-4.

\section{Derry 2008}

Derry S, Moore RA, McQuay HJ. Single dose oral celecoxib for acute postoperative pain. Cochrane Database of Systematic Reviews 2008, Issue 4. [DOI: 10.1002/14651858.CD004233]

\section{Derry 2009}

Derry C, Derry S, Moore RA, McQuay HJ. Single dose oral ibuprofen for acute postoperative pain in adults. Cochrane Database of Systematic Reviews 2009, Issue 3. [DOI: 10.1002/14651858.CD001548.pub2]

\section{Edwards 1999a}

Edwards JE, McQuay HJ, Moore RA, Collins SL. Reporting of adverse effects in clinical trials should be improved - lessons from acute pain. Journal of Pain and Symptom Management 1999;18:427-37.

\section{Fitzgerald 2001}

FitzGerald GA, Patrono C. The coxibs, selective inhibitors of cyclooxygenase-2. New England Journal of Medicine 2001;345(6):433-42.

\section{Houde 1965}

Houde RW, Wallenstein SL, Beaver WT. Clinical measurement of pain. In: De Stevens G editor(s). Analgetics. New York and London: Academic Press, 1965:75-122.

\section{Jadad 1996a}

Jadad AR, Carroll D, Moore A, McQuay H. Developing a database of published reports of randomised clinical trials in pain research. Pain 1996;66:239-46.

\section{Jadad 1996b}

Jadad AR, Moore RA, Carroll D, Jenkinson C, Reynolds DJM, Gavaghan DJ, et al. Assessing the quality of reports of randomized clinical trials: is blinding necessary?. Controlled Clinical Trials 1996;17:1-12.

\section{L'Abbé 1987}

L'Abbé KA, Detsky AS, O'Rourke K. Meta-analysis in clinical research. Annals of Internal Medicine 1987;107:224-33.

\section{McQuay 2005}

McQuay HJ, Moore RA. Placebo. Postgraduate Medical Journal 2005;81:155-60. [DOI: 10.1136/pgmj.2004.024737]

\section{McQuay 2007}

McQuay HJ, Moore RA. Dose-response in direct comparisons of different doses of aspirin, ibuprofen and paracetamol (acetaminophen) in analgesic studies. British Journal of Clinical Pharmacology 2007;63(3):271-8. [DOI: 10.1111/ j.1365-2125.2006.02723.x]

\section{Moore 1996}

Moore RA, McQuay HJ, Gavaghan DJ. Deriving dichotomous outcome measures from continuous data in randomised controlled trials of analgesics. Pain 1996;66:229-37.

\section{Moore 1997a}

Moore A, McQuay H, Gavaghan D. Deriving dichotomous outcome measures from continuous data in randomised 
controlled trials of analgesics: verification from independent data. Pain 1997;69:127-30.

\section{Moore 1997b}

Moore A, Moore O, McQuay H, Gavaghan D. Deriving dichotomous outcome measures from continuous data in randomised controlled trials of analgesics: use of pain intensity and visual analogue scales. Pain 1997;69:311-5.

\section{Moore 1998}

Moore RA, Gavaghan D, Tramer MR, Collins SL, McQuay HJ. Size is everything-large amounts of information are needed to overcome random effects in estimating direction and magnitude of treatment effects. Pain 1998;78(3):209-16. [DOI: 10.1016/S0304-3959(98)00140-7]

\section{Moore 2003}

Moore RA, Edwards J, Barden J, McQuay HJ. Bandolier's Little Book of Pain. Oxford: Oxford University Press, 2003. [ISBN: 0-19-263247-7]

\section{Moore 2005}

Moore RA, Edwards JE, McQuay HJ. Acute pain: individual patient meta-analysis shows the impact of different ways of analysing and presenting results. Pain 2005;116(3):322-31. [DOI: 10.1016/j.pain.2005.05.001]

\section{Moore 2006}

Moore A, McQuay H. Bandolier's Little Book of Making Sense of the Medical Evidence. Oxford: Oxford University Press, 2006. [ISBN: 0-19-856604-2]

\section{Moore 2008}

Moore RA, Barden J, Derry S, McQuay HJ. Managing potential publication bias. In: McQuay HJ, Kalso E, Moore RA editor(s). Systematic Reviews in Pain Research: Methodology Refined. Seattle: IASP Press, 2008:15-23. [ISBN: 978-0-931092-69-5]

\section{Moore 2011}

Moore RA, Derry S, McQuay HJ, Wiffen PJ. Single dose oral analgesics for acute postoperative pain in adults.

\section{CHARACTERISTICS OF STUDIES}

Characteristics of included studies [ordered by study ID]
Cochrane Database of Systematic Reviews 2011, Issue 9. [DOI: 10.1002/14651858.CD008659.pub2]

\section{Morris 1995}

Morris JA, Gardner MJ. Calculating confidence intervals for relative risk, odds ratio and standardised ratios and rates. In: Gardner MJ, Altman DG editor(s). Statistics with Confidence Confidence Intervals and Statistical Guidelines. London: British Medical Journal, 1995:50-63.

\section{PCA 2011}

The NHS Information Centre, Prescribing Support Unit. Prescription Cost Analysis England 2010. The Health and Social Care Information Centre 2011.

\section{RevMan 2011 [Computer program]}

The Nordic Cochrane Centre, The Cochrane Collaboration. Review Manager (RevMan). Version 5.1. Copenhagen: The Nordic Cochrane Centre, The Cochrane Collaboration, 2011.

\section{Toms 2008}

Toms L, McQuay HJ, Derry S, Moore RA. Single dose oral paracetamol (acetaminophen) for postoperative pain in adults. Cochrane Database of Systematic Reviews 2008, Issue 4. [DOI: 10.1002/14651858.CD004602]

\section{References to other published versions of this review}

\section{Edwards 1999b}

Edwards JE, Oldman A, Smith L, Carroll D, Wiffen PJ, McQuay HJ, et al. Oral aspirin in postoperative pain: a quantitative systematic review. Pain 1999;81:289-97.

\section{Edwards 2000}

Edwards JE, Oldman A, Smith L, Collins SL, Carroll D, Wiffen PJ, et al. Single dose oral aspirin for acute pain. Cochrane Database of Systematic Reviews 2000, Issue 2. [DOI: 10.1002/14651858.CD002067]

* Indicates the major publication for the study

\section{Bloomfield 1967}

\begin{tabular}{ll} 
Methods & RCT, DB, single oral dose, parallel groups. Medication administered when pain was moderate or severe \\
& Assessed at $0,1,2,3,4,5,6 \mathrm{~h}$ \\
\hline Participants & Episiotomy \\
& $\mathrm{N}=100$ (88 moderate/severe pain) \\
Age 18 to 39 years
\end{tabular}


Bloomfield 1967 (Continued)

Chlorphenesin $800 \mathrm{mg}, \mathrm{n}=17$

Chlorphenesin $400 \mathrm{mg}+$ aspirin $600 \mathrm{mg}, \mathrm{n}=18$

Placebo, $\mathrm{n}=18$

\begin{tabular}{lll}
\hline Outcomes & Pl: standard 4-point scale & Adverse events \\
& Withdrawals & \\
\hline Notes & Oxford Quality Score: $\mathrm{R}=1, \mathrm{DB}=2, \mathrm{~W}=1$. Total $=4$. \\
\hline Risk of bias & & \\
\hline Bias & Authors' judgement & Support for judgement \\
\hline $\begin{array}{l}\text { Random sequence genera- } \\
\text { tion (selection bias) }\end{array}$ & Unclear risk & "randomly assigned" but method not described \\
\hline $\begin{array}{l}\text { Allocation concealment } \\
\text { (selection bias) }\end{array}$ & Unclear risk & Not described \\
\hline $\begin{array}{l}\text { Blinding (performance } \\
\text { bias and detection bias) } \\
\begin{array}{l}\text { All outcomes } \\
\hline\end{array}\end{array}$ & Low risk & "identical black capsules" \\
\hline
\end{tabular}

\section{Boraks 1987}

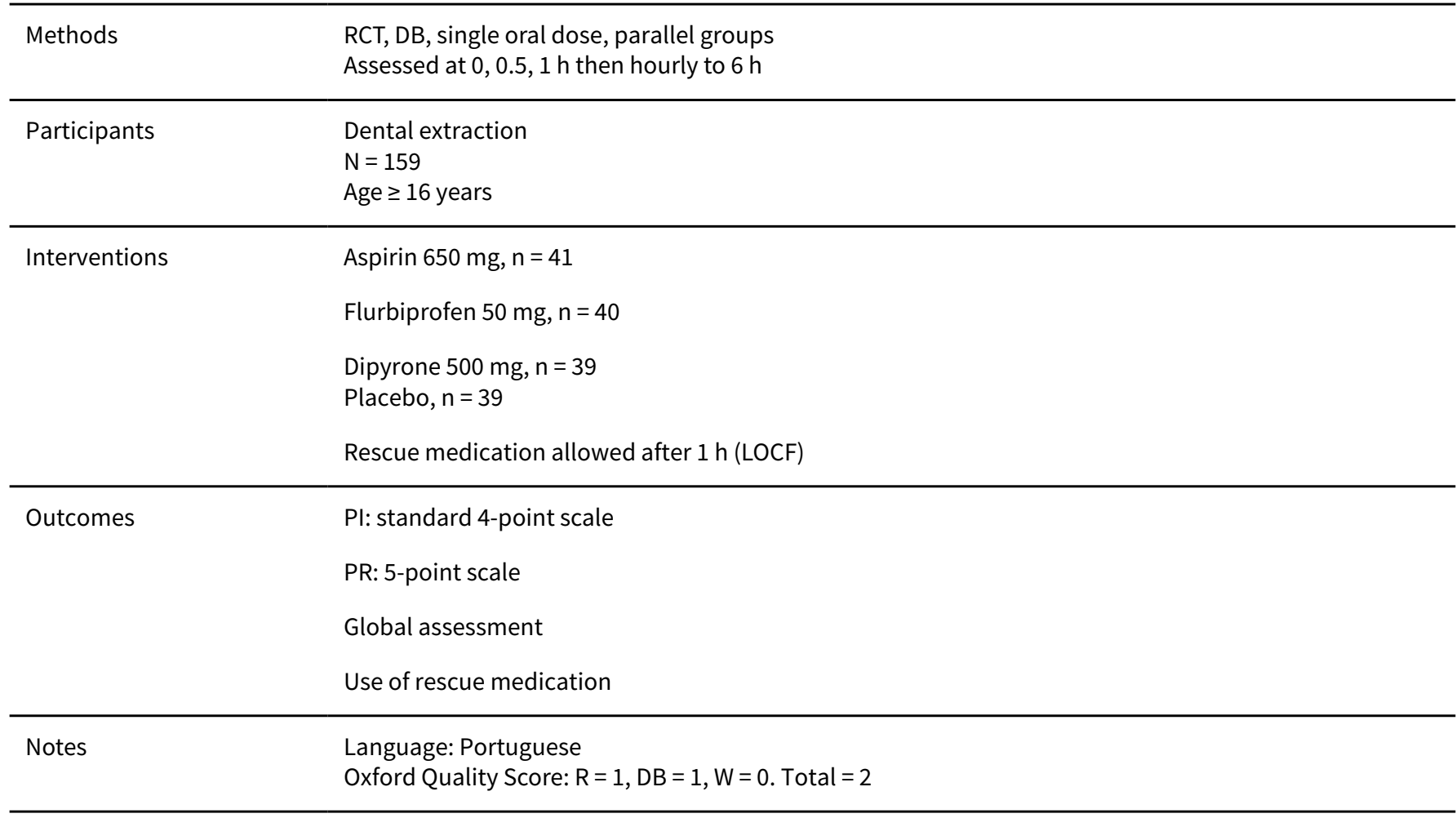

\section{Risk of bias}


Boraks 1987 (Continued)

\begin{tabular}{lll} 
Bias & Authors' judgement & Support for judgement \\
\hline $\begin{array}{l}\text { Random sequence genera- } \\
\text { tion (selection bias) }\end{array}$ & Unclear risk & Not described \\
\hline $\begin{array}{l}\text { Allocation concealment } \\
\text { (selection bias) }\end{array}$ & Unclear risk & Not described \\
\hline
\end{tabular}

Blinding (performance $\quad$ Unclear risk
bias and detection bias)

Breivik 1984

\begin{tabular}{ll}
\hline Methods & $\begin{array}{l}\text { RCT, DB, single oral dose, parallel groups } \\
\text { Assessed at } 0,0.5,1 \mathrm{~h} \text { then hourly to } 8 \mathrm{~h}\end{array}$ \\
\hline Participants & $\begin{array}{l}\text { Orthopaedic surgery (knee, ankle etc) } \\
\mathrm{N}=120 \\
\text { Age } 18 \text { to } 65 \text { years }\end{array}$ \\
\hline
\end{tabular}

\begin{tabular}{ll}
\hline Interventions & Aspirin $650 \mathrm{mg}, \mathrm{n}=29$ \\
& Piroxicam $5 \mathrm{mg}, \mathrm{n}=30$ \\
& Piroxicam $10 \mathrm{mg}, \mathrm{n}=31$ \\
& Placebo, $\mathrm{n}=30$ \\
& Rescue medication allowed after $2 \mathrm{~h}$ (paracetamol plus codeine) \\
\hline Outcomes & Pl: standard 4-point scale \\
& Pl: VAS (none to unbearable pain) \\
& PR: standard 5-point scale \\
& Global assessment: 5 -point scale \\
& Use of rescue medication \\
& Adverse events \\
& Oxford Quality Score: $\mathrm{R}=1, \mathrm{DB}=2, \mathrm{~W}=0$. Total $=3$
\end{tabular}

\section{Risk of bias}

\begin{tabular}{lll}
\hline Bias & Authors' judgement & Support for judgement \\
\hline $\begin{array}{l}\text { Random sequence genera- } \\
\text { tion (selection bias) }\end{array}$ & Unclear risk & Not described \\
\hline $\begin{array}{l}\text { Allocation concealment } \\
\text { (selection bias) }\end{array}$ & Unclear risk & Not described \\
\hline $\begin{array}{l}\text { Blinding (performance } \\
\text { bias and detection bias) } \\
\text { All outcomes }\end{array}$ & Low risk & Double dummy \\
\hline
\end{tabular}


Calimlim 1977

\begin{tabular}{|c|c|c|}
\hline Methods & \multicolumn{2}{|c|}{$\begin{array}{l}\mathrm{RCT}, \mathrm{DB} \text {, single oral dose, parallel groups } \\
\text { Assessed at } 0,0.5,1 \mathrm{~h} \text { then hourly to } 5 \mathrm{~h}\end{array}$} \\
\hline Participants & \multicolumn{2}{|c|}{$\begin{array}{l}\text { Postsurgical patients (exact type of surgery not reported) } \\
N=100 \text { ( } 98 \text { included, but only } 74 \text { with global ratings) } \\
\text { Age } 21 \text { to } 65 \text { years }\end{array}$} \\
\hline Interventions & \multicolumn{2}{|c|}{$\begin{array}{l}\text { Aspirin } 650 \mathrm{mg}, \mathrm{n}=23 \\
\text { Aspirin } 325 \mathrm{mg} \text { + pentazocine } 25 \mathrm{mg}, \mathrm{n}=25 \\
\text { Aspirin } 650 \mathrm{mg} \text { + pentazocine } 50 \mathrm{mg}, \mathrm{n}=50 \\
\text { Placebo, } \mathrm{n}=26 \\
\text { Rescue medication generally not allowed before } 3 \mathrm{~h} \text { (standard analgesic) (BOCF) }\end{array}$} \\
\hline Outcomes & \multicolumn{2}{|c|}{$\begin{array}{l}\text { PI: non-standard 5-point scale and VAS } 20 \mathrm{~cm} \text { (no pain at all - worst pain ever experienced) } \\
\text { PR: standard 5-point scale } \\
\text { Global assessment: 5-point scale }\end{array}$} \\
\hline Notes & \multicolumn{2}{|c|}{ Oxford Quality Score: R = 1, DB $=1, W=1$. Total $=3$} \\
\hline \multicolumn{3}{|l|}{ Risk of bias } \\
\hline Bias & Authors' judgement & Support for judgement \\
\hline $\begin{array}{l}\text { Random sequence genera- } \\
\text { tion (selection bias) }\end{array}$ & Unclear risk & Not described \\
\hline $\begin{array}{l}\text { Allocation concealment } \\
\text { (selection bias) }\end{array}$ & Unclear risk & Not described \\
\hline $\begin{array}{l}\text { Blinding (performance } \\
\text { bias and detection bias) } \\
\text { All outcomes }\end{array}$ & Unclear risk & Not described \\
\hline
\end{tabular}

\section{Clark 1989}

\begin{tabular}{ll}
\hline Methods & $\begin{array}{l}\text { RCT, DB, single oral dose, parallel groups } \\
\text { Assessed at } 0,1 \mathrm{~h} \text { then hourly to } 12 \mathrm{~h}\end{array}$ \\
\hline Participants & $\begin{array}{l}\text { Oral surgery } \\
\mathrm{N}=248\end{array}$ \\
& Age 15 to 63 years \\
\hline Interventions & Aspirin $600 \mathrm{mg}, \mathrm{n} \sim 40$ \\
& Carprofen $75 \mathrm{mg}, \mathrm{n}=\sim 40$ \\
& Carprofen $100 \mathrm{mg}, \mathrm{n}=\sim 40$ \\
& Carprofen $150 \mathrm{mg}, \mathrm{n}=\sim 40$ \\
& Placebo, $\mathrm{n} \sim 40$
\end{tabular}


Clark 1989 (Continued)

Rescue medication allowed after $1 \mathrm{~h}$

\begin{tabular}{ll} 
Outcomes & PI: standard 4-point scale \\
& PR: standard 5-point scale \\
& Global assessment: standard 5-point scale \\
& Use of rescue medication \\
& Adverse events \\
\hline Notes & Oxford Quality Score: $\mathrm{R}=1, \mathrm{DB}=1, \mathrm{~W}=0$. Total $=2$
\end{tabular}

\section{Risk of bias}

\begin{tabular}{lll}
\hline Bias & Authors' judgement & Support for judgement \\
\hline $\begin{array}{l}\text { Random sequence genera- } \\
\text { tion (selection bias) }\end{array}$ & Unclear risk & Not described \\
\hline $\begin{array}{l}\text { Allocation concealment } \\
\text { (selection bias) }\end{array}$ & Unclear risk & Not described \\
\hline $\begin{array}{l}\text { Blinding (performance } \\
\text { bias and detection bias) } \\
\begin{array}{l}\text { All outcomes } \\
\hline\end{array}\end{array}$ & Unclear risk & Not described \\
\hline
\end{tabular}

\section{Cooper 1977}

\begin{tabular}{ll}
\hline Methods & RCT, DB, single oral dose, parallel groups \\
& Assessed at 0,1 and hourly to $4 \mathrm{~h}$ \\
\hline Participants & Oral surgery - impacted teeth \\
& $\mathrm{N}=245$ \\
& Age 16 to 35 years \\
\hline Interventions & Aspirin $325 \mathrm{mg}, \mathrm{n}=37$ \\
& Aspirin $650 \mathrm{mg}, \mathrm{n}=37$ \\
& Ibuprofen $200 \mathrm{mg}, \mathrm{n}=38$ \\
& Ibuprofen $400 \mathrm{mg}, \mathrm{n}=40$ \\
& Placebo, $\mathrm{n}=40$ \\
& Rescue medication allowed after $2 \mathrm{~h}$ (routine clinic medication) (BOCF) \\
\hline Outcomes & Pl: standard 4-point scale \\
& PR: standard 5-point scale \\
& Global assessment: standard 5-point scale \\
& Serious adverse events \\
Withdrawals
\end{tabular}

\section{Risk of bias}


Cooper 1977 (Continued)

\section{Bias Authors' judgement Support for judgement}

Random sequence genera- Low risk ～"Medications assigned using a card-shuffling technique"

tion (selection bias)

\begin{tabular}{lll}
\hline $\begin{array}{l}\text { Allocation concealment } \\
\text { (selection bias) }\end{array}$ & Low risk & "tablets in an envelope identified only by a sequential number" \\
\hline $\begin{array}{l}\text { Blinding (performance } \\
\text { bias and detection bias) } \\
\text { All outcomes }\end{array}$ & Low risk & "two identically appearing tablets" \\
\hline
\end{tabular}

\section{Cooper 1979a}

\begin{tabular}{|c|c|c|}
\hline Methods & \multicolumn{2}{|c|}{$\begin{array}{l}\mathrm{RCT}, \mathrm{DB} \text {, single oral dose, parallel groups } \\
\text { Assessed at } 0,1 \mathrm{~h} \text { then hourly to } 4 \mathrm{~h} \\
\text { Study } 2\end{array}$} \\
\hline Participants & \multicolumn{2}{|c|}{$\begin{array}{l}\text { Oral surgery } \\
\mathrm{N}=254 \text { ( } 201 \text { for efficacy analyses) } \\
\text { Age adult }\end{array}$} \\
\hline Interventions & \multicolumn{2}{|c|}{$\begin{array}{l}\text { Aspirin } 600 \mathrm{mg}, \mathrm{n}=47 \\
\text { Indoprofen } 100 \mathrm{mg}, \mathrm{n}=46 \\
\text { Indoprofen } 200 \mathrm{mg}, \mathrm{n}=50 \\
\text { Placebo, } \mathrm{n}=58 \\
\text { Rescue medication allowed after } 1 \mathrm{~h} \text { (did not report data handling) }\end{array}$} \\
\hline Outcomes & $\begin{array}{l}\text { PI: standard 4-point sc } \\
\text { PR: standard 5-point s } \\
\text { Global assessment: sta } \\
\text { Adverse events } \\
\text { Withdrawals }\end{array}$ & $\begin{array}{l}\text { le } \\
\text { idard 5-point scale }\end{array}$ \\
\hline Notes & \multicolumn{2}{|c|}{ Oxford Quality Score: $R=2, D B=2, W=1$. Total $=5$} \\
\hline \multicolumn{3}{|l|}{ Risk of bias } \\
\hline Bias & Authors' judgement & Support for judgement \\
\hline $\begin{array}{l}\text { Random sequence genera- } \\
\text { tion (selection bias) }\end{array}$ & Low risk & "computer-generated codes" \\
\hline $\begin{array}{l}\text { Allocation concealment } \\
\text { (selection bias) }\end{array}$ & Low risk & $\begin{array}{l}\text { "medication was placed in an envelope identified only by a sequential number } \\
\text { code" }\end{array}$ \\
\hline $\begin{array}{l}\text { Blinding (performance } \\
\text { bias and detection bias) } \\
\text { All outcomes }\end{array}$ & Low risk & "identically-appearing capsules" \\
\hline
\end{tabular}


Cooper 1982

\begin{tabular}{|c|c|c|}
\hline Methods & \multicolumn{2}{|c|}{$\begin{array}{l}\mathrm{RCT}, \mathrm{DB} \text {, single oral dose, parallel groups } \\
\text { Assessed at } 0,1 \mathrm{~h} \text { then hourly to } 4 \mathrm{~h}\end{array}$} \\
\hline Participants & \multicolumn{2}{|c|}{$\begin{array}{l}\text { Dental impaction } \\
\mathrm{N}=316 \text { ( } 249 \text { for efficacy analyses) } \\
\text { Age } 16 \text { to } 65 \text { years }\end{array}$} \\
\hline Interventions & $\begin{array}{l}\text { Aspirin } 650 \mathrm{mg}, \mathrm{n}=38 \\
\text { Ibuprofen } 400 \mathrm{mg}, \mathrm{n}= \\
\text { Codeine } 60 \mathrm{mg}, \mathrm{n}=41 \\
\text { Aspirin } 650 \mathrm{mg}+\text { code } \\
\text { Ibuprofen } 400 \mathrm{mg}+\mathrm{co} \\
\text { Placebo, } \mathrm{n}=46 \\
\text { Rescue medication all }\end{array}$ & $\begin{array}{l}\text { e } 60 \mathrm{mg}, \mathrm{n}=45 \\
\text { eine } 60 \mathrm{mg}, \mathrm{n}=45 \\
\text { Ned after } 1 \mathrm{~h} \text { (LOCF) }\end{array}$ \\
\hline Outcomes & $\begin{array}{l}\text { PI: standard 4-point sc } \\
\text { PR: standard 5-point s } \\
\text { Use of rescue medicat } \\
\text { Adverse events } \\
\text { Withdrawals }\end{array}$ & $\begin{array}{l}\text { le } \\
\text { ale }\end{array}$ \\
\hline Notes & \multicolumn{2}{|c|}{ Oxford Quality Score: R = 1, DB $=2, W=1$. Total $=4$} \\
\hline \multicolumn{3}{|l|}{ Risk of bias } \\
\hline Bias & Authors' judgement & Support for judgement \\
\hline $\begin{array}{l}\text { Random sequence genera- } \\
\text { tion (selection bias) }\end{array}$ & Unclear risk & Not described \\
\hline $\begin{array}{l}\text { Allocation concealment } \\
\text { (selection bias) }\end{array}$ & Unclear risk & Not described \\
\hline $\begin{array}{l}\text { Blinding (performance } \\
\text { bias and detection bias) } \\
\text { All outcomes }\end{array}$ & Low risk & Tablets "appeared identical for every patient" \\
\hline
\end{tabular}

\section{Cooper 1983}

$\begin{array}{ll}\text { Methods } & \text { RCT, DB, single oral dose, parallel groups } \\ \text { Assessed at } 0,0.5,1 \mathrm{~h} \text { then hourly to } 6 \mathrm{~h}\end{array}$

\begin{tabular}{ll}
\hline Participants & $\begin{array}{l}\text { Peridontal treatment } \\
\mathrm{N}=199(176 \text { for efficacy an } \\
\end{array}$ \\
& Age adults \\
\hline Interventions & Aspirin $650 \mathrm{mg}, \mathrm{n}=43$ \\
& Suprofen $200 \mathrm{mg}, \mathrm{n}=44$
\end{tabular}


Cooper 1983 (Continued)

Suprofen $400 \mathrm{mg}, \mathrm{n}=45$

Placebo, $n=44$

Rescue medication allowed after $1 \mathrm{~h}$ (LOCF)

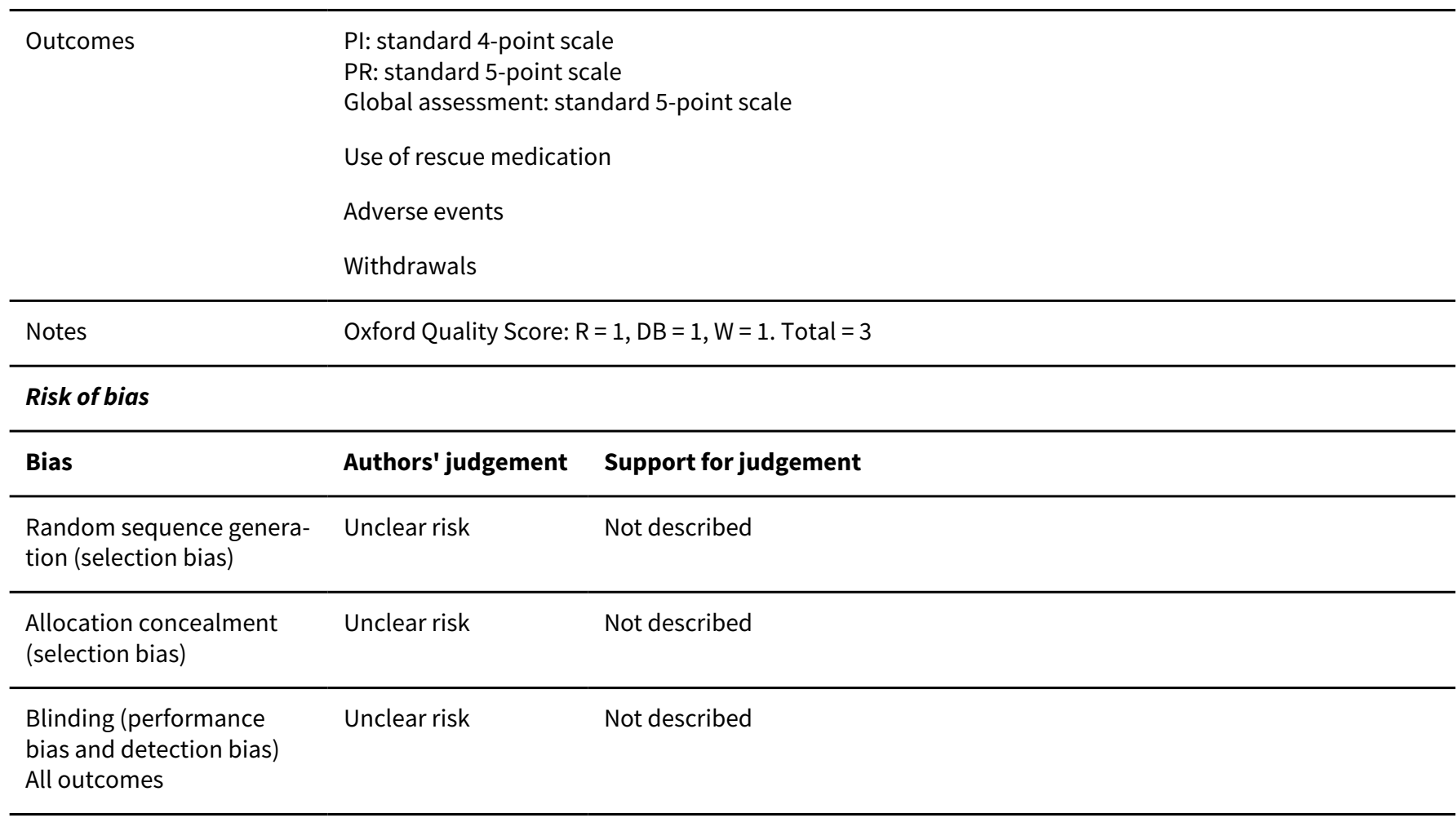

Cooper 1986

$\begin{array}{ll}\text { Methods } & \text { RCT, DB, single oral dose, parallel groups } \\ \text { Assessed at } 0.5,1 \mathrm{~h} \text { then hourly to } 6 \mathrm{~h} \\ \text { Study C }\end{array}$

\begin{tabular}{ll}
\hline Participants & Dental extraction (third molar) \\
$N=211$ (204 for efficacy analyses) \\
Age 18 to 46
\end{tabular}

Interventions

\author{
Aspirin $650 \mathrm{mg}, \mathrm{n}=40$ \\ Aspirin $650 \mathrm{mg}+$ codeine $60 \mathrm{mg}, \mathrm{n}=39$ \\ Suprofen $200 \mathrm{mg}, \mathrm{n}=42$ \\ Suprofen $400 \mathrm{mg}, \mathrm{n}=42$ \\ Placebo, $n=41$
}

Rescue medication allowed after $1 \mathrm{~h}$ (paracetamol + codeine) (LOCF)

\begin{tabular}{ll}
\hline Outcomes & PI standard 4-point scale \\
& PR standard 5-point scale \\
& Global standard 5-point scale \\
& Use of rescue medication \\
& Adverse events
\end{tabular}


Cooper 1986 (Continued)

Withdrawals

Notes Oxford Quality Score: $\mathrm{R}=2, \mathrm{DB}=2, \mathrm{~W}=1$. Total $=5$

\section{Risk of bias}

\begin{tabular}{lll}
\hline Bias & Authors' judgement & Support for judgement \\
\hline $\begin{array}{l}\text { Random sequence genera- } \\
\text { tion (selection bias) }\end{array}$ & Low risk & "computer-generated" \\
\hline $\begin{array}{l}\text { Allocation concealment } \\
\text { (selection bias) }\end{array}$ & Low risk & Identical bottles bearing sequential number \\
\hline $\begin{array}{l}\text { Blinding (performance } \\
\text { bias and detection bias) } \\
\text { All outcomes }\end{array}$ & Low risk & "double-dummy technique" \\
\hline
\end{tabular}

\section{Cooper 1988}

Methods $\quad$ RCT, DB, single oral dose, parallel groups

Assessed at $0,0.5,1 \mathrm{~h}$ then hourly to $8 \mathrm{~h}$

$\begin{array}{ll}\text { Participants } & \text { Dental surgery (impacted third molars) } \\ \mathrm{N}=159 \text { (151 for efficacy analyses) }\end{array}$

Age adult

\begin{tabular}{ll}
\hline Interventions & Aspirin $600 \mathrm{mg}, \mathrm{n}=29$ \\
& Flurbiprofen $50 \mathrm{mg}, \mathrm{n}=30$ \\
& Flurbiprofen $100 \mathrm{mg}, \mathrm{n}=30$ \\
& Flurbiprofen $150 \mathrm{mg}, \mathrm{n}=29$ \\
& Placebo, $\mathrm{n}=33$ \\
& Rescue medication allowed after $1 \mathrm{~h}$ (LOCF)
\end{tabular}

\begin{tabular}{ll}
\hline Putcomes & Ptandard 4-point scale \\
PR: standard 5-point scale \\
Global assessment: standard 5-point scale \\
Use of rescue medication \\
Adverse events \\
Withdrawals
\end{tabular}

Notes Oxford Quality Score: $\mathrm{R}=1, \mathrm{DB}=1, \mathrm{~W}=1$. Total $=3$

\section{Risk of bias}

\begin{tabular}{lll}
\hline Bias & Authors' judgement & Support for judgement \\
\hline $\begin{array}{l}\text { Random sequence genera- } \\
\text { tion (selection bias) }\end{array}$ & Unclear risk & Not described \\
\hline
\end{tabular}


Cooper 1988 (Continued)

\begin{tabular}{lll}
$\begin{array}{l}\text { Allocation concealment } \\
\text { (selection bias) }\end{array}$ & Low risk & Remote allocation \\
\hline $\begin{array}{l}\text { Blinding (performance } \\
\text { bias and detection bias) }\end{array}$ & Unclear risk & Not described \\
$\begin{array}{l}\text { All outcomes } \\
\text { Pat }\end{array}$ &
\end{tabular}

\section{Cooper 1991}

$\begin{array}{ll}\text { Methods } & \text { RCT, DB, single oral dose, parallel groups } \\ \text { Assessed at } 0,0.5,1 \mathrm{~h} \text { then hourly to } 6 \mathrm{~h}\end{array}$

\begin{tabular}{|c|c|c|}
\hline \multirow{2}{*}{$\begin{array}{l}\text { Participants } \\
\text { Interventions }\end{array}$} & \multicolumn{2}{|c|}{$\begin{array}{l}\text { Dental surgery (impacted third molar) } \\
\mathrm{N}=189 \text { ( } 182 \text { for efficacy) } \\
\text { Age } \geq 16 \text { years }\end{array}$} \\
\hline & \multicolumn{2}{|c|}{$\begin{array}{l}\text { Aspirin } 650 \mathrm{mg}, \mathrm{n}=46 \\
\text { Meclofenamate } 50 \mathrm{mg}, \mathrm{n}=40 \\
\text { Meclofenamate } 100 \mathrm{mg}, \mathrm{n}=48 \\
\text { Placebo, } \mathrm{n}=48 \\
\text { Rescue medication allowed after } 1 \mathrm{~h} \text { (BOCF) }\end{array}$} \\
\hline Outcomes & $\begin{array}{l}\text { PI: standard 4-point sc } \\
\text { PR: standard 5-point s } \\
\text { Global assessment: st } \\
\text { Use of rescue medicat } \\
\text { Adverse events } \\
\text { Withdrawals }\end{array}$ & $\begin{array}{l}\text { le } \\
\text { ale } \\
\text { dard 5-point scale }\end{array}$ \\
\hline Notes & \multicolumn{2}{|c|}{ Oxford Quality Score: $R=2, D B=2, W=1$. Total $=5$} \\
\hline \multicolumn{3}{|l|}{ Risk of bias } \\
\hline Bias & Authors' judgement & Support for judgement \\
\hline $\begin{array}{l}\text { Random sequence genera- } \\
\text { tion (selection bias) }\end{array}$ & Low risk & "computer-generated randomization code" \\
\hline $\begin{array}{l}\text { Allocation concealment } \\
\text { (selection bias) }\end{array}$ & Unclear risk & Not described \\
\hline $\begin{array}{l}\text { Blinding (performance } \\
\text { bias and detection bias) } \\
\text { All outcomes }\end{array}$ & Low risk & "identically appearing single doses" \\
\hline
\end{tabular}

\section{Cooper 1992}

Methods

RCT, DB, single oral dose, parallel groups

Assessed at $0.5,1 \mathrm{~h}$ then hourly to $8 \mathrm{~h}$ 
Cooper 1992 (Continued)

Pental surgery (impacted third molar)
$\mathrm{N}=112$ (104 for efficacy analyses)
Age 16 to 59 years

\begin{tabular}{ll}
\hline Interventions & Aspirin $650 \mathrm{mg}, \mathrm{n}=28$ \\
& Oxaprozin $600 \mathrm{mg}, \mathrm{n}=28$ \\
& Oxaprozin $1200 \mathrm{mg}, \mathrm{n}=22$ \\
placebo $\mathrm{n}=26$
\end{tabular}

\begin{tabular}{|c|c|c|}
\hline Outcomes & \multicolumn{2}{|c|}{$\begin{array}{l}\text { PI: standard 4-point scale } \\
\text { PR: non-standard 6-point scale } \\
\text { Global assessment: 5-point standard } \\
\text { Use of rescue medication }\end{array}$} \\
\hline Notes & \multicolumn{2}{|c|}{ Oxford Quality Score: R= 1, DB = 2, W $=1$. Total $=4$} \\
\hline \multicolumn{3}{|l|}{ Risk of bias } \\
\hline Bias & Authors' judgement & Support for judgement \\
\hline $\begin{array}{l}\text { Random sequence genera- } \\
\text { tion (selection bias) }\end{array}$ & Unclear risk & Not described \\
\hline $\begin{array}{l}\text { Allocation concealment } \\
\text { (selection bias) }\end{array}$ & Unclear risk & Not described \\
\hline $\begin{array}{l}\text { Blinding (performance } \\
\text { bias and detection bias) } \\
\text { All outcomes }\end{array}$ & Low risk & "tablets and their packaging were identical" \\
\hline
\end{tabular}

Coutinho 1976

\begin{tabular}{ll}
\hline Methods & $\begin{array}{l}\text { RCT, DB, single oral dose, parallel groups } \\
\text { Assessed at } 0,0.5,1 \mathrm{~h} \text { then hourly to } 5 \mathrm{~h}\end{array}$ \\
\hline Participants & $\begin{array}{l}\text { Urogenital surgery (various) } \\
\mathrm{N}=90 \\
\text { Age } 23 \text { to } 64 \text { years }\end{array}$ \\
\hline Interventions & Aspirin $600 \mathrm{mg} \mathrm{n}=15$ \\
& Fenbufen $400 \mathrm{mg}, \mathrm{n}=15$ \\
& Fenbufen $800 \mathrm{mg}, \mathrm{n}=16$ \\
& Codeine $30 \mathrm{mg}, \mathrm{n}=14$ \\
& $\begin{array}{l}\text { Propoxyphene } 65 \mathrm{mg}, \mathrm{n}=15 \\
\text { Placebo } \mathrm{n}=15\end{array}$ \\
& Rescue medication allowed after $4 \mathrm{~h}$ (coded - aspirin or fenbufen) (LOCF) \\
\hline
\end{tabular}


Coutinho 1976 (Continued)

\begin{tabular}{ll} 
Outcomes & PI: standard 4-point scale \\
& PR: standard 5-point scale \\
& Adverse events \\
\hline Notes & Oxford Quality Score: $\mathrm{R}=2, \mathrm{DB}=2, \mathrm{~W}=0$. Total $=4$
\end{tabular}

\section{Risk of bias}

\begin{tabular}{lll}
\hline Bias & Authors' judgement & Support for judgement \\
\hline $\begin{array}{l}\text { Random sequence genera- } \\
\text { tion (selection bias) }\end{array}$ & Low risk & "computer-generated randomization list" \\
\hline
\end{tabular}

\begin{tabular}{lll}
\hline $\begin{array}{l}\text { Allocation concealment } \\
\text { (selection bias) }\end{array}$ & Unclear risk & Not described \\
\hline $\begin{array}{l}\text { Blinding (performance } \\
\text { bias and detection bias) } \\
\text { All outcomes }\end{array}$ & Low risk & "identically-appearing capsules, administered in a single oral dose" \\
\hline
\end{tabular}

\section{De Vroey 1977}

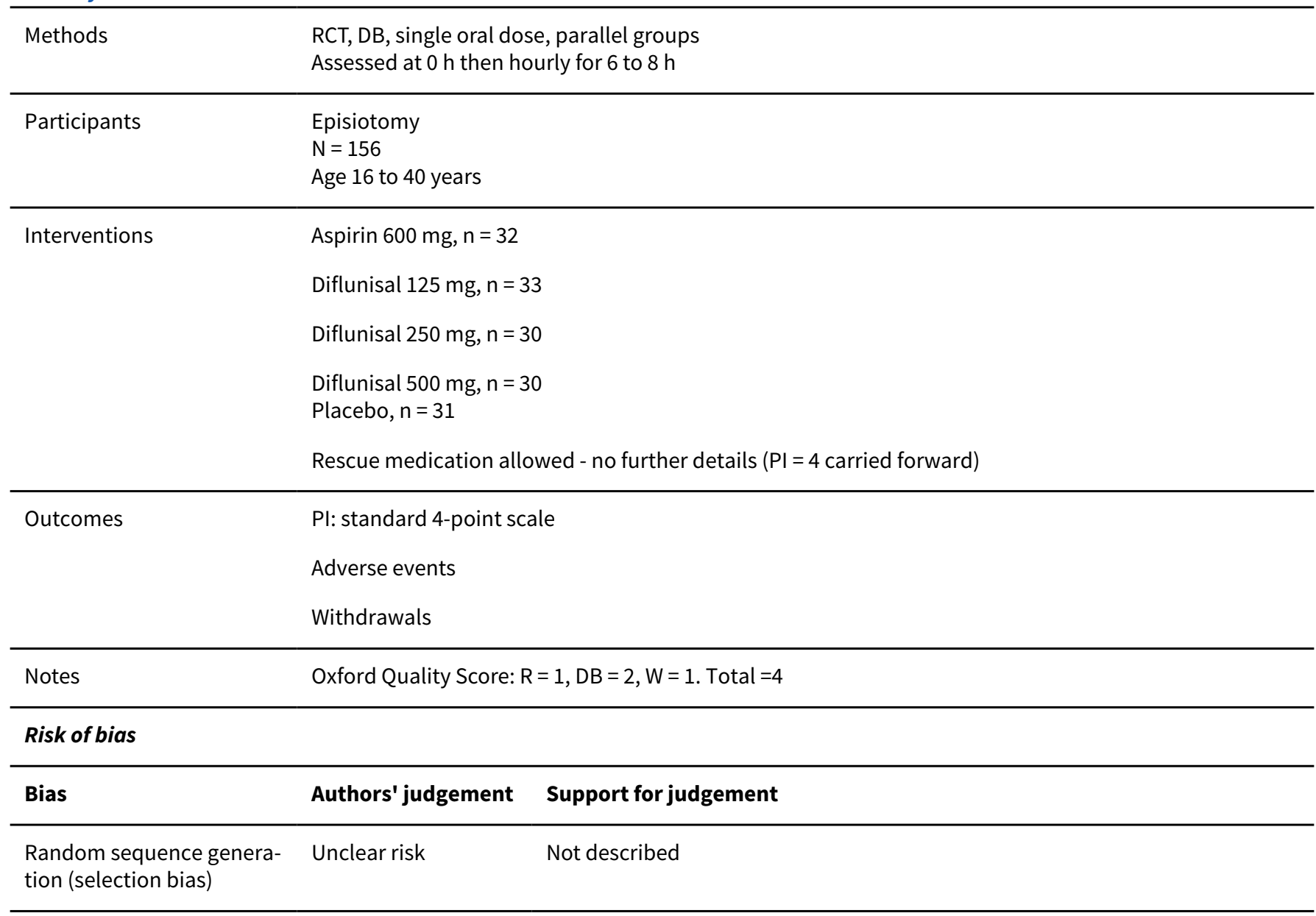


De Vroey 1977 (Continued)

\begin{tabular}{|c|c|c|}
\hline $\begin{array}{l}\text { Allocation concealment } \\
\text { (selection bias) }\end{array}$ & Low risk & "individual patient-coded vials" \\
\hline $\begin{array}{l}\text { Blinding (performance } \\
\text { bias and detection bias) } \\
\text { All outcomes }\end{array}$ & Low risk & "two identically appearing capsules" \\
\hline
\end{tabular}

\section{Desjardins 1984}

$\begin{array}{ll}\text { Methods } & \mathrm{RCT}, \mathrm{DB} \text {, single oral dose, parallel groups } \\ \text { Assessed at } 0,0.5,1 \mathrm{~h} \text { then hourly to } 6 \mathrm{~h}\end{array}$

\begin{tabular}{|c|c|c|}
\hline Participants & \multicolumn{2}{|c|}{$\begin{array}{l}\text { Dental extraction (impacted third molar) } \\
N=160 \text { ( } 159 \text { for efficacy analyses) } \\
\text { Age } 18 \text { to } 68 \text { years }\end{array}$} \\
\hline \multirow[t]{4}{*}{ Interventions } & \multicolumn{2}{|l|}{ Aspirin $650 \mathrm{mg}, \mathrm{n}=40$} \\
\hline & \multicolumn{2}{|c|}{ Propiram fumarate $50 \mathrm{mg}, \mathrm{n}=40$} \\
\hline & \multicolumn{2}{|l|}{$\begin{array}{l}\text { Codeine } 60 \mathrm{mg}, \mathrm{n}=40 \\
\text { Placebo, } \mathrm{n}=40\end{array}$} \\
\hline & \multicolumn{2}{|c|}{ Rescue medication allowed - participants asked to wait as long as possible } \\
\hline \multirow[t]{4}{*}{ Outcomes } & \multicolumn{2}{|c|}{$\begin{array}{l}\text { PI: standard 4-point scale } \\
\text { PR: standard 5-point scale } \\
\text { Global assessment: standard 5-point scale }\end{array}$} \\
\hline & \multicolumn{2}{|c|}{ Use of rescue medication } \\
\hline & \multicolumn{2}{|l|}{ Adverse events } \\
\hline & \multicolumn{2}{|l|}{ Withdrawals } \\
\hline Notes & \multicolumn{2}{|c|}{ Oxford Quality Score: $R=1, D B=2, W=1$. Total $=4$} \\
\hline \multicolumn{3}{|l|}{ Risk of bias } \\
\hline Bias & Authors' judgement & Support for judgement \\
\hline $\begin{array}{l}\text { Random sequence genera- } \\
\text { tion (selection bias) }\end{array}$ & Unclear risk & Not described \\
\hline $\begin{array}{l}\text { Allocation concealment } \\
\text { (selection bias) }\end{array}$ & Unclear risk & Not described \\
\hline $\begin{array}{l}\text { Blinding (performance } \\
\text { bias and detection bias) } \\
\text { All outcomes }\end{array}$ & Low risk & "medications identical in appearance (two capsules)" \\
\hline
\end{tabular}

Fliedner 1984

$\begin{array}{ll}\text { Methods } & \text { RCT, DB, single oral dose, parallel groups } \\ \text { Assessed at } 0.5,1 \mathrm{~h} \text { then hourly to } 12 \mathrm{~h}\end{array}$


Fliedner 1984 (Continued)

Participants $\quad$ Dental extraction (impacted third molar)
$\mathrm{N}=384$ (380 for efficacy analyses)

Age not reported

\begin{tabular}{ll}
\hline Interventions & Aspirin $650 \mathrm{mg}, \mathrm{n}=83$ \\
& Etodolac $50 \mathrm{mg}, \mathrm{n}=37$ \\
& Etodolac $100 \mathrm{mg}, \mathrm{n}=87$ \\
& Etodolac $200 \mathrm{mg}, \mathrm{n}=86$ \\
& Placebo $\mathrm{n}=87$ \\
& Rescue medication allowed (no further details) (BOCF)
\end{tabular}

\begin{tabular}{|c|c|c|}
\hline Outcomes & $\begin{array}{l}\text { PI: non-standard 5-po } \\
\text { PR: 5-point scale } \\
\text { Global assessment: no } \\
\text { Adverse events } \\
\text { Withdrawals }\end{array}$ & $\begin{array}{l}\text { it scale } \\
\text {-standard 4-point scale }\end{array}$ \\
\hline Notes & Oxford Quality Score: & $=1, \mathrm{DB}=1, \mathrm{~W}=1$. Total $=3$ \\
\hline Risk of bias & & \\
\hline Bias & Authors' judgement & Support for judgement \\
\hline $\begin{array}{l}\text { Random sequence genera- } \\
\text { tion (selection bias) }\end{array}$ & Unclear risk & Not described \\
\hline $\begin{array}{l}\text { Allocation concealment } \\
\text { (selection bias) }\end{array}$ & Unclear risk & Not described \\
\hline $\begin{array}{l}\text { Blinding (performance } \\
\text { bias and detection bias) } \\
\text { All outcomes }\end{array}$ & Unclear risk & Not described \\
\hline
\end{tabular}

\section{Forbes 1980}

\begin{tabular}{ll}
\hline Methods & $\begin{array}{l}\text { RCT, DB, single oral dose, parallel groups } \\
\text { Assessed at } 0,1 \mathrm{~h} \text { then hourly to } 4 \mathrm{~h}\end{array}$ \\
\hline Participants & $\begin{array}{l}\text { Dental surgery (impacted third molar) } \\
\mathrm{N}=247 \\
\text { Age } \geq 15 \text { years }\end{array}$ \\
\hline Interventions & Aspirin $650 \mathrm{mg}, \mathrm{n}=38$ \\
& Proquazone $75 \mathrm{mg}, \mathrm{n}=40$ \\
& Proquazone $150 \mathrm{mg}, \mathrm{n}=44$ \\
& $\begin{array}{l}\text { Proquazone } 300 \mathrm{mg}, \mathrm{n}=45 \\
\text { placebo } \mathrm{n}=43\end{array}$ \\
& Rescue medication allowed after $1 \mathrm{~h}$ (BOCF) \\
\hline
\end{tabular}


Forbes 1980 (Continued)

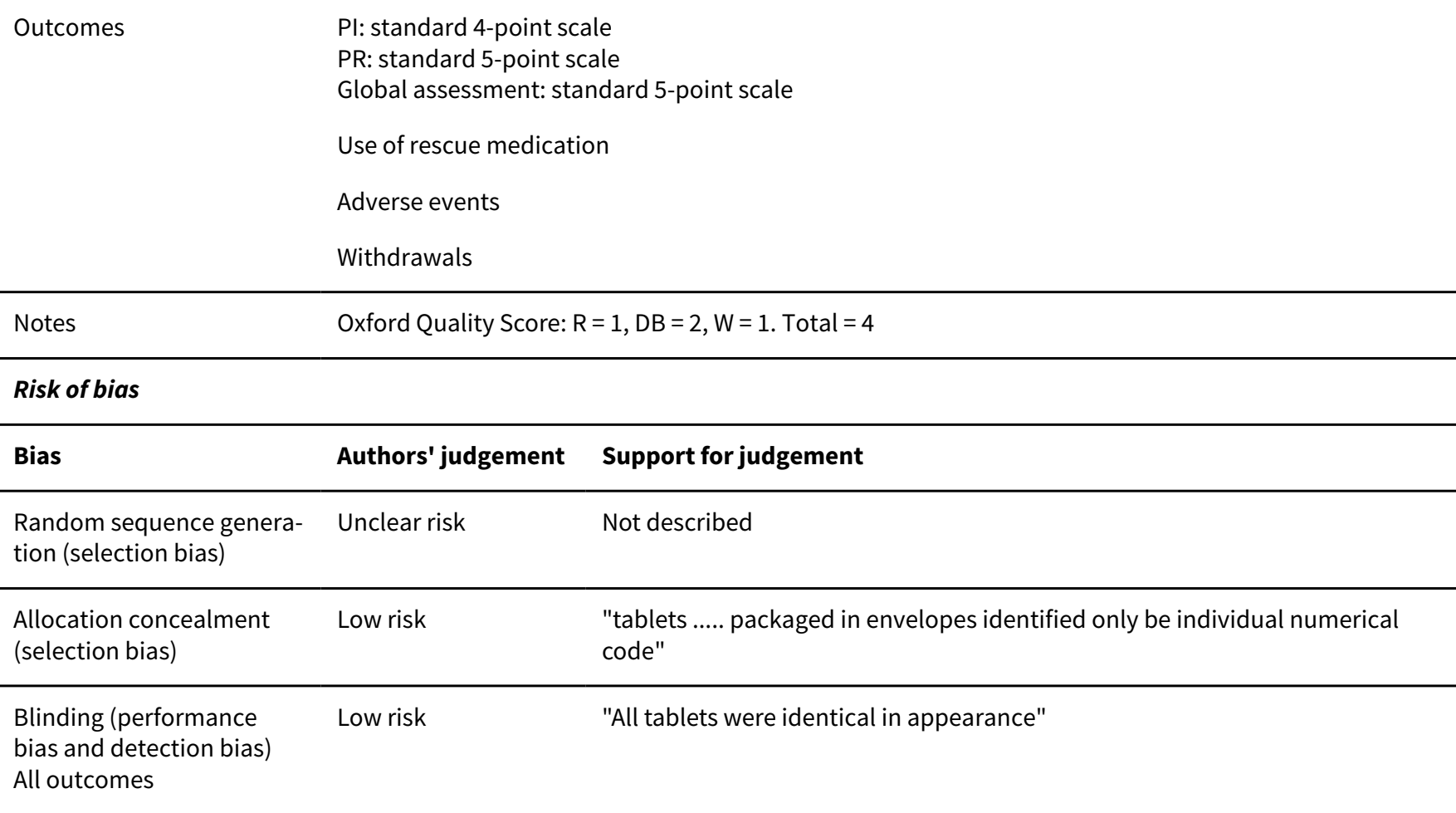

Forbes 1982

\begin{tabular}{|c|c|}
\hline Methods & $\begin{array}{l}\mathrm{RCT}, \mathrm{DB} \text {, single oral dose, parallel groups } \\
\text { Assessed at } 0,1 \mathrm{~h} \text { then hourly to } 12 \mathrm{~h}\end{array}$ \\
\hline Participants & $\begin{array}{l}\text { Dental surgery (multiple mandibular or impacted third molar) } \\
N=212 \text { ( } 201 \text { for efficacy analyses) } \\
\text { Age } \geq 15 \text { years }\end{array}$ \\
\hline Interventions & $\begin{array}{l}\text { Aspirin } 650 \mathrm{mg}, \mathrm{n}=42 \\
\text { Diflunisal } 250 \mathrm{mg}, \mathrm{n}=39 \\
\text { Diflunisal } 500 \mathrm{mg}, \mathrm{n}=41 \\
\text { Diflunisal } 1000 \mathrm{mg}, \mathrm{n}=41 \\
\text { Placebo, } \mathrm{n}=38 \\
\text { Rescue medication allowed after } 2 \mathrm{~h} \text { (BOCF) }\end{array}$ \\
\hline Outcomes & $\begin{array}{l}\text { PI: standard 4-point scale } \\
\text { PR: standard 5-point scale } \\
\text { Global assessment: standard 5-point scale } \\
\text { Use of rescue medication } \\
\text { Adverse events } \\
\text { Withdrawals }\end{array}$ \\
\hline
\end{tabular}


Forbes 1982 (Continued)

\section{Risk of bias}

\begin{tabular}{lll}
\hline Bias & Authors' judgement & Support for judgement \\
\hline $\begin{array}{l}\text { Random sequence genera- } \\
\text { tion (selection bias) }\end{array}$ & Low risk & Computer-generated random numbers list \\
\hline $\begin{array}{l}\text { Allocation concealment } \\
\text { (selection bias) }\end{array}$ & Low risk & $\begin{array}{l}\text { "treatments ... packaged in envelopes identified only by individual numerical } \\
\text { code" }\end{array}$ \\
\hline $\begin{array}{l}\text { Blinding (performance } \\
\text { bias and detection bias) } \\
\begin{array}{l}\text { All outcomes } \\
\hline\end{array}\end{array}$ & Low risk & "treatments were identical in appearance" \\
\hline
\end{tabular}

Forbes 1983

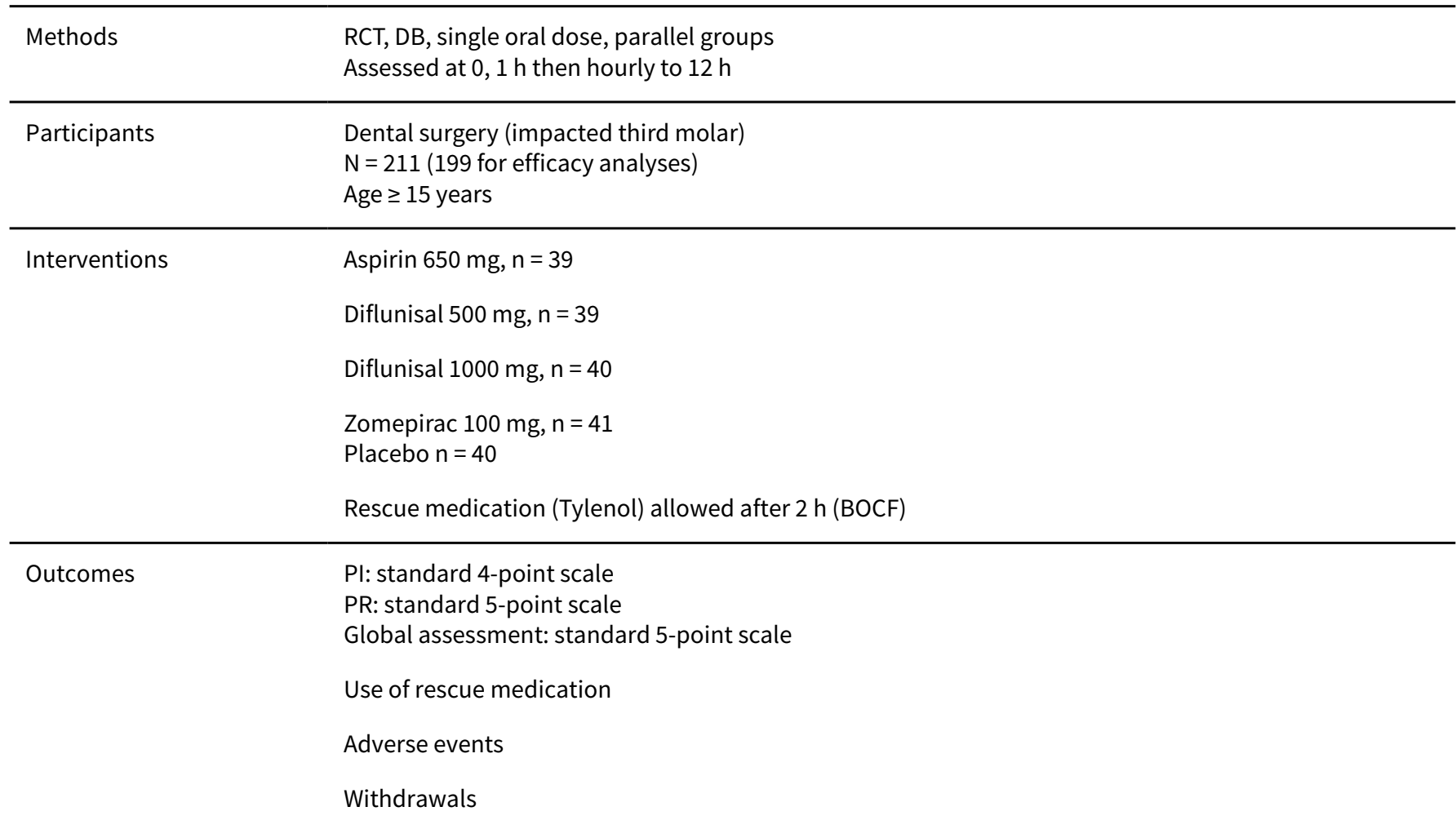

Notes Oxford Quality Score: $\mathrm{R}=2, \mathrm{DB}=2, \mathrm{~W}=1$. Total $=5$

\section{Risk of bias}

\begin{tabular}{lll}
\hline Bias & Authors' judgement & Support for judgement \\
\hline $\begin{array}{l}\text { Random sequence genera- } \\
\text { tion (selection bias) }\end{array}$ & Low risk & Computer-generated random numbers list \\
\hline $\begin{array}{l}\text { Allocation concealment } \\
\text { (selection bias) }\end{array}$ & Unclear risk & Not described \\
\hline
\end{tabular}


Forbes 1983 (Continued)

Blinding (performance $\quad$ Low risk
bias and detection bias)

All outcomes

\section{Forbes 1984}

\begin{tabular}{|c|c|c|}
\hline Methods & \multicolumn{2}{|c|}{$\begin{array}{l}\mathrm{RCT}, \mathrm{DB} \text {, single oral dose, parallel groups } \\
\text { Assessed at } 0,1 \mathrm{~h} \text { then hourly to } 12 \mathrm{~h}\end{array}$} \\
\hline Participants & \multicolumn{2}{|c|}{$\begin{array}{l}\text { Dental surgery (impacted third molar) } \\
N=115 \text { ( } 109 \text { for efficacy analyses) } \\
\text { Age } \geq 15 \text { years }\end{array}$} \\
\hline Interventions & \multicolumn{2}{|c|}{$\begin{array}{l}\text { Aspirin } 650 \mathrm{mg} \mathrm{n}=24 \\
\text { Fendosal } 200 \mathrm{mg}, \mathrm{n}=29 \\
\text { Ibuprofen } 400 \mathrm{mg}, \mathrm{n}=28 \\
\text { Placebo, } \mathrm{n}=28 \\
\text { Rescue medication allowed after } 2 \mathrm{~h} \text { (BOCF) }\end{array}$} \\
\hline Outcomes & $\begin{array}{l}\text { PI: standard 4-point sc } \\
\text { PR: standard 5-point s } \\
\text { Global assessment: st } \\
\text { Use of rescue medicat } \\
\text { Adverse events } \\
\text { Withdrawals }\end{array}$ & $\begin{array}{l}\text { le } \\
\text { ale } \\
\text { odard 5-point scale }\end{array}$ \\
\hline Notes & \multicolumn{2}{|c|}{ Oxford Quality Score: R=2, DB =2, W = 1. Total $=5$} \\
\hline \multicolumn{3}{|l|}{ Risk of bias } \\
\hline Bias & Authors' judgement & Support for judgement \\
\hline $\begin{array}{l}\text { Random sequence genera- } \\
\text { tion (selection bias) }\end{array}$ & Low risk & Computer-generated random numbers list \\
\hline $\begin{array}{l}\text { Allocation concealment } \\
\text { (selection bias) }\end{array}$ & Unclear risk & Not described \\
\hline $\begin{array}{l}\text { Blinding (performance } \\
\text { bias and detection bias) } \\
\text { All outcomes }\end{array}$ & Low risk & Double-dummy technique \\
\hline
\end{tabular}

\section{Forbes 1986}

$\begin{array}{ll}\text { Methods } & \text { RCT, DB, single oral dose, parallel groups } \\ \text { Assessed at } 0,1 \mathrm{~h} \text { then hourly to } 12 \mathrm{~h}\end{array}$

Assessed at $0,1 \mathrm{~h}$ then hourly to $12 \mathrm{~h}$

$\begin{array}{ll}\text { Participants } & \text { Dental surgery (impacted third molar) } \\ N=222 \text { (198 for efficacy analyses) }\end{array}$

$\mathrm{N}=222$ (198 for efficacy analyses) 
Forbes 1986 (Continued)

Age $\geq 15$ years

\begin{tabular}{ll}
\hline Interventions & Aspirin $650 \mathrm{mg}, \mathrm{n}=36$ \\
& Naproxen $550 \mathrm{mg}, \mathrm{n}=38$ \\
& Codeine $60 \mathrm{mg}, \mathrm{n}=44$ \\
& Naproxen $550 \mathrm{mg}+$ codeine $60 \mathrm{mg}, \mathrm{n}=38$ \\
& Placebo, $\mathrm{n}=42$ \\
& Rescue medication (paracetamol + codeine) allowed after $2 \mathrm{~h}$ (BOCF) \\
\hline Outcomes & Pl: standard 4-point scale \\
& PR: standard 5-point scale \\
Global assessment: standard 5-point scale & \\
& Use of rescue medication \\
& Adverse events \\
Withdrawals
\end{tabular}

Notes Oxford Quality Score: $\mathrm{R}=2, \mathrm{DB}=2, \mathrm{~W}=1$. Total $=5$

\section{Risk of bias}

\section{Bias}

Random sequence genera- Low risk tion (selection bias)

\begin{tabular}{lll}
\hline $\begin{array}{l}\text { Allocation concealment } \\
\text { (selection bias) }\end{array}$ & Low risk & Not described \\
\hline $\begin{array}{l}\text { Blinding (performance } \\
\text { bias and detection bias) } \\
\text { All outcomes }\end{array}$ & Low risk & Double-dummy technique \\
\hline
\end{tabular}

Forbes 1989

\begin{tabular}{ll}
\hline Methods & $\begin{array}{l}\text { RCT, DB, single oral dose, parallel groups } \\
\text { Assessed at } 0,1 \mathrm{~h} \text { then hourly to } 8 \mathrm{~h}\end{array}$ \\
\hline Participants & $\begin{array}{l}\text { Dental surgery (impacted third molar) } \\
\mathrm{N}=191 \text { (164 for efficacy) } \\
\text { Age } \geq 15 \text { years }\end{array}$ \\
\hline Interventions & Aspirin $600 \mathrm{mg}, \mathrm{n}=31$ \\
& Flurbiprofen $25 \mathrm{mg}, \mathrm{n}=31$ \\
& Flurbiprofen $50 \mathrm{mg}, \mathrm{n}=33$ \\
& Flurbiprofen $100 \mathrm{mg}, \mathrm{n}=36$ \\
& Placebo $\mathrm{n}=33$ \\
& Rescue medication (paracetamol + codeine) allowed after $2 \mathrm{~h}$ (BOCF) \\
\hline
\end{tabular}


Forbes 1989 (Continued)

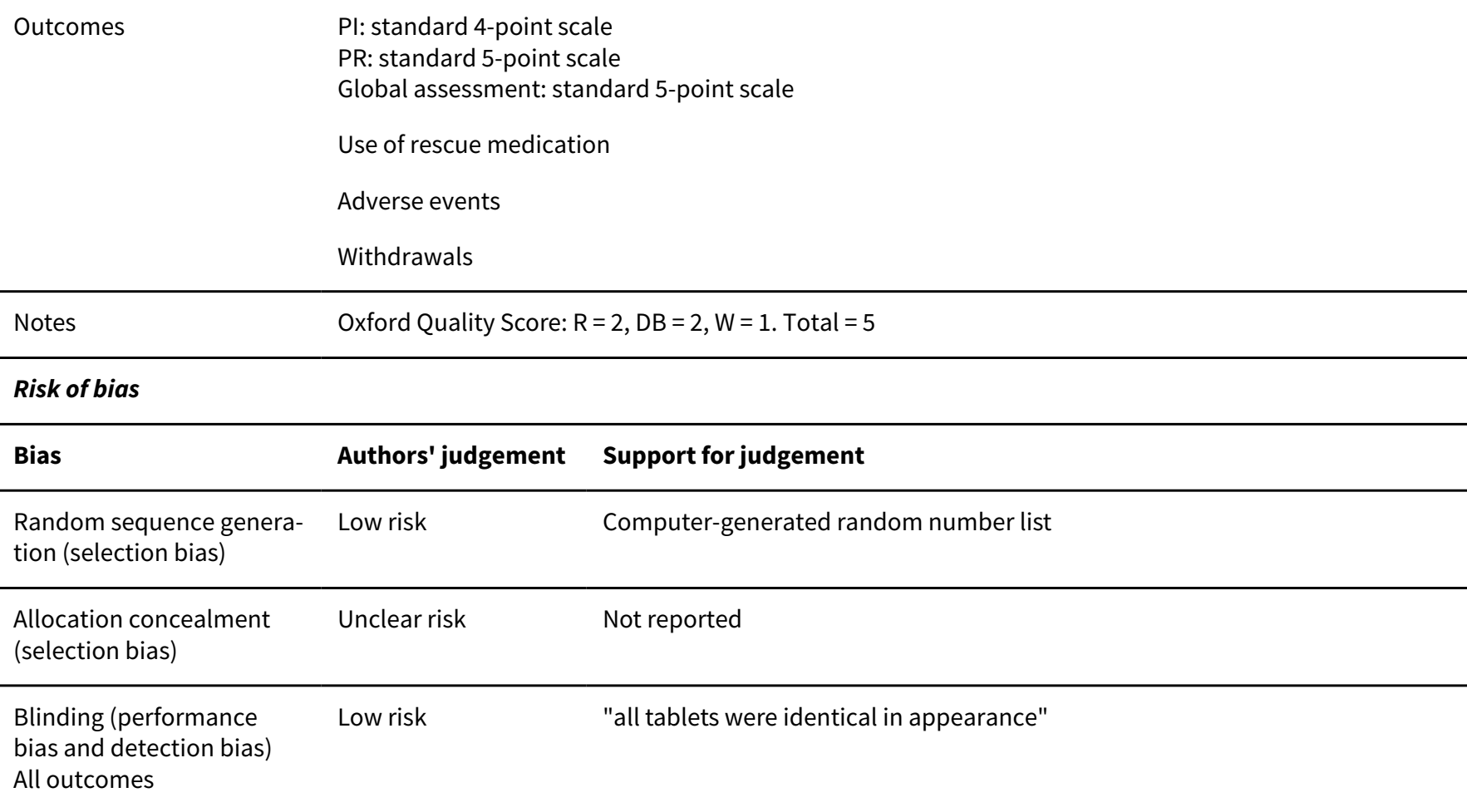

Forbes 1990a

\begin{tabular}{|c|c|}
\hline Methods & $\begin{array}{l}\text { RCT, DB, single oral dose, parallel groups } \\
\text { Assessed at } 0,1 \text { h then hourly to } 6\end{array}$ \\
\hline Participants & $\begin{array}{l}\text { Dental surgery (impacted third molar) } \\
N=404 \text { ( } 350 \text { for efficacy analyses) } \\
\text { Age } \geq 15 \text { years }\end{array}$ \\
\hline Interventions & $\begin{array}{l}\text { Aspirin } 650 \mathrm{mg}, \mathrm{n}=68 \\
\text { Aspirin } 1000 \mathrm{mg}, \mathrm{n}=71 \\
\text { Caffeine } 65 \mathrm{mg}, \mathrm{n}=70 \\
\text { Aspirin } 650 \mathrm{mg}+\text { caffeine } 65 \mathrm{mg}, \mathrm{n}=66 \\
\text { Placebo } \mathrm{n}=75 \\
\text { Rescue medication allowed after } 2 \mathrm{~h} \text { (BOCF) }\end{array}$ \\
\hline Outcomes & $\begin{array}{l}\text { PI: standard 4-point scale } \\
\text { PR: standard 5-point scale } \\
\text { Global assessment: standard 5-point scale } \\
\text { Use of rescue medication } \\
\text { Adverse events } \\
\text { Withdrawals }\end{array}$ \\
\hline Notes & Oxford Quality Score: $R=2, D B=2, W=1$. Total $=5$ \\
\hline
\end{tabular}

\section{Risk of bias}


Forbes 1990a (Continued)

Bias

Random sequence genera- Low risk tion (selection bias)

\section{Allocation concealment} (selection bias)

Unclear risk

Low risk

Blinding (performance

bias and detection bias)

All outcomes

\section{Authors' judgement Support for judgement}

Computer-generated random number list

Not described

"all tablets were identical in appearance"

Forbes 1990b

\begin{tabular}{ll}
\hline Methods & $\begin{array}{l}\text { RCT, DB, single oral dose, parallel groups } \\
\text { Assessed at } 0,1 \mathrm{~h} \text { then hourly to } 6 \mathrm{~h}\end{array}$ \\
\hline Participants & $\begin{array}{l}\text { Dental surgery (impacted third molar) } \\
\mathrm{N}=153 \text { (128 for efficacy analyses) } \\
\text { Age } \geq 15 \text { years }\end{array}$ \\
\hline Interventions & Aspirin $650 \mathrm{mg}, \mathrm{n}=32$ \\
& Ketorolac $10 \mathrm{mg}, \mathrm{n}=37$ \\
& $\begin{array}{l}\text { Paracetamol } 600 \mathrm{mg}+\text { codeine } 60 \mathrm{mg}, \mathrm{n}=27 \\
\text { Placebo } \mathrm{n}=32\end{array}$ \\
& Rescue medication (Tylenol) allowed after $2 \mathrm{~h}(\mathrm{BOCF})$ \\
\hline Outcomes & Pl: standard 4-point scale \\
& PR: standard 5-point scale \\
& Global assessment: standard 5-point scale \\
& Use of rescue medication \\
& Adverse events \\
Withdrawals
\end{tabular}

\section{Risk of bias}

\section{Bias}

Random sequence genera- Low risk tion (selection bias)

\begin{tabular}{lll}
\hline $\begin{array}{l}\text { Allocation concealment } \\
\text { (selection bias) }\end{array}$ & Unclear risk & Not described \\
\hline $\begin{array}{l}\text { Blinding (performance } \\
\text { bias and detection bias) }\end{array}$ & Low risk & "capsules were identical in appearance" \\
All outcomes & &
\end{tabular}

\section{Authors' judgement Support for judgement}

Computer-generated random number list

(1)


Forbes 1991

\begin{tabular}{ll}
\hline Methods & $\begin{array}{l}\text { RCT, DB, single oral dose, parallel groups } \\
\text { Assessed at } 0,1 \mathrm{~h} \text { then hourly to } 8 \mathrm{~h}\end{array}$ \\
\hline Participants & $\begin{array}{l}\text { Dental surgery (impacted third molar) } \\
\mathrm{N}=276 \text { (241 for efficacy analyses) } \\
\text { Age } 15 \text { to } 44 \text { years }\end{array}$ \\
\hline Interventions & Aspirin $650 \mathrm{mg}, \mathrm{n}=41$ \\
& Ibuprofen $400 \mathrm{mg}, \mathrm{n}=37$ \\
& Bromfenac $5 \mathrm{mg}, \mathrm{n}=39$ \\
& Bromfenac $10 \mathrm{mg}, \mathrm{n}=43$ \\
& Bromfenac $25 \mathrm{mg}, \mathrm{n}=42$ \\
& Placebo $\mathrm{n}=39$ \\
& Rescue medication (Vicodin) allowed after $2 \mathrm{~h}$ (BOCF)
\end{tabular}

\begin{tabular}{|c|c|c|}
\hline \multirow[t]{4}{*}{ Outcomes } & \multicolumn{2}{|c|}{$\begin{array}{l}\text { PI: standard 4-point scale } \\
\text { PR: standard 5-point scale } \\
\text { Global assessment: standard 5-point scale }\end{array}$} \\
\hline & \multicolumn{2}{|c|}{ Use of rescue medication } \\
\hline & \multicolumn{2}{|l|}{ Adverse events } \\
\hline & \multicolumn{2}{|l|}{ Withdrawals } \\
\hline Notes & \multicolumn{2}{|c|}{ Oxford Quality Score: $\mathrm{R}=2, \mathrm{DB}=2, \mathrm{~W}=1$. Total $=5$} \\
\hline \multicolumn{3}{|l|}{ Risk of bias } \\
\hline Bias & Authors' judgement & Support for judgement \\
\hline $\begin{array}{l}\text { Random sequence genera- } \\
\text { tion (selection bias) }\end{array}$ & Low risk & Computer-generated random number list \\
\hline $\begin{array}{l}\text { Allocation concealment } \\
\text { (selection bias) }\end{array}$ & Unclear risk & Not described \\
\hline $\begin{array}{l}\text { Blinding (performance } \\
\text { bias and detection bias) } \\
\text { All outcomes }\end{array}$ & Low risk & "all capsules were identical in appearance" \\
\hline
\end{tabular}

Forbes 1992

\begin{tabular}{ll}
\hline Methods & RCT, DB, single oral dose, parallel groups \\
& Assessed at $0,1 \mathrm{~h}$ then hourly to $8 \mathrm{~h}$ \\
\hline Participants & Dental surgery (impacted third molar) \\
& $\begin{array}{l}\mathrm{N}=324 \text { (280 for efficacy analyses) } \\
\text { Age } 15 \text { to } 56 \text { years }\end{array}$ \\
\hline Interventions & Aspirin $650 \mathrm{mg}, \mathrm{n}=38$
\end{tabular}


Forbes 1992 (Continued)

$$
\begin{aligned}
& \text { Ibuprofen } 400 \mathrm{mg}, \mathrm{n}=38 \\
& \text { Bromfenac } 10 \mathrm{mg}, \mathrm{n}=43 \\
& \text { Bromfenac } 25 \mathrm{mg}, \mathrm{n}=41 \\
& \text { Bromfenac } 50 \mathrm{mg}, \mathrm{n}=42 \\
& \text { Bromfenac } 100 \mathrm{mg}, \mathrm{n}=40 \\
& \text { Placebo } \mathrm{n}=38
\end{aligned}
$$

Rescue medication (Vicodin) allowed after $2 \mathrm{~h}$ (BOCF)

\begin{tabular}{ll}
\hline Outcomes & PI: standard 4-point scale \\
& PR: standard 5-point scale \\
& Global assessment: standard 5-point scale \\
& Use of rescue medication \\
& Adverse events \\
& Withdrawals \\
\hline Notes & Oxford Quality Score: $\mathrm{R}=2, \mathrm{DB}=2, \mathrm{~W}=1$. Total $=5$
\end{tabular}

\section{Risk of bias}

\section{Bias}

\section{Authors' judgement Support for judgement}

Random sequence genera- Low risk Computer-generated random number list tion (selection bias)

\begin{tabular}{lll}
\hline $\begin{array}{l}\text { Allocation concealment } \\
\text { (selection bias) }\end{array}$ & Unclear risk & Not described \\
\hline $\begin{array}{l}\text { Blinding (performance } \\
\text { bias and detection bias) }\end{array}$ & Low risk & "all capsules were identical in appearance" \\
All outcomes & &
\end{tabular}

\section{Frame 1986}

\begin{tabular}{ll}
\hline Methods & $\begin{array}{l}\text { RCT, DB, single oral dose, parallel groups } \\
\text { Assessed at } 0,1 \mathrm{~h} \text { then hourly to } 5 \mathrm{~h}\end{array}$ \\
\hline Participants & $\begin{array}{l}\text { Dental surgery (impacted third molar) } \\
\mathrm{N}=159 \text { (141 for efficacy analyses) } \\
\text { Mean age } 24 \text { years }\end{array}$ \\
\hline Interventions & Aspirin $600 \mathrm{mg}, \mathrm{n}=25$ \\
& Ibuprofen $200 \mathrm{mg}+$ codeine $15 \mathrm{mg}, \mathrm{n}=32$ \\
& Ibuprofen $400 \mathrm{mg}+$ codeine $30 \mathrm{mg}, \mathrm{n}=32$ \\
& Ibuprofen $800 \mathrm{mg}+$ codeine $60 \mathrm{mg}, \mathrm{n}=26$ \\
& Placebo $\mathrm{n}=26$ \\
& Rescue medication (paracetamol) allowed after $2 \mathrm{~h}$ \\
\hline Outcomes & Pl: non-standard 9-point scale \\
\hline
\end{tabular}


Frame 1986 (Continued)

PR: standard 5-point scale

Global assessment (no scale reported)

Use of rescue medication

Adverse events

Withdrawals

Notes Oxford Quality Score: $\mathrm{R}=1, \mathrm{DB}=2, \mathrm{~W}=1$. Total $=3$

\section{Risk of bias}

\begin{tabular}{lll}
\hline Bias & Authors' judgement & Support for judgement \\
\hline $\begin{array}{l}\text { Random sequence genera- } \\
\text { tion (selection bias) }\end{array}$ & Unclear risk & Not described \\
\hline $\begin{array}{l}\text { Allocation concealment } \\
\text { (selection bias) }\end{array}$ & Low risk & Sealed sachets \\
\hline $\begin{array}{l}\text { Blinding (performance } \\
\text { bias and detection bias) } \\
\text { All outcomes }\end{array}$ & Low risk & "aspirin specially formulated to match the other drugs" \\
\hline
\end{tabular}

Gaston 1984

\begin{tabular}{ll}
\hline Methods & RCT, DB, single oral dose, parallel groups \\
Assessed at $0,0.5,1 \mathrm{~h}$ then hourly to $8 \mathrm{~h}$
\end{tabular}

\begin{tabular}{ll}
\hline Participants & Oral surgery \\
& $\mathrm{N}=161$ \\
& Mean age 27 years \\
\hline Interventions & Aspirin $650 \mathrm{mg}, \mathrm{n}=40$ \\
& Etodolac $50 \mathrm{mg}, \mathrm{n}=39$ \\
& Etodolac $200 \mathrm{mg}, \mathrm{n}=40$ \\
& Placebo, $\mathrm{n}=42$ \\
& Rescue medication allowed after $1 \mathrm{~h}$ (BOCF) \\
& Pl: non-standard 5-point scale \\
& PR: 5-point scale \\
& Global assessment: non-standard 4-point scale \\
Outcomes & Use of rescue medication \\
& Adverse events \\
& Withdrawals
\end{tabular}

Notes Oxford Quality Score: $\mathrm{R}=1, \mathrm{DB}=1, \mathrm{~W}=1$. Total $=3$


Gaston 1984 (Continued)

\section{Risk of bias}

\begin{tabular}{lll}
\hline Bias & Authors' judgement & Support for judgement \\
\hline $\begin{array}{l}\text { Random sequence genera- } \\
\text { tion (selection bias) }\end{array}$ & Unclear risk & Not described \\
\hline $\begin{array}{l}\text { Allocation concealment } \\
\text { (selection bias) }\end{array}$ & Unclear risk & Not described \\
\hline $\begin{array}{l}\text { Blinding (performance } \\
\text { bias and detection bias) } \\
\text { All outcomes }\end{array}$ & Unclear risk & Not described \\
\hline
\end{tabular}

\section{Gaston 1986}

$\begin{array}{ll}\text { Methods } & \text { RCT, DB, single oral dose, parallel groups } \\ \text { Assessed at } 0,0.5,1 \mathrm{~h} \text { then hourly to } 12 \mathrm{~h}\end{array}$

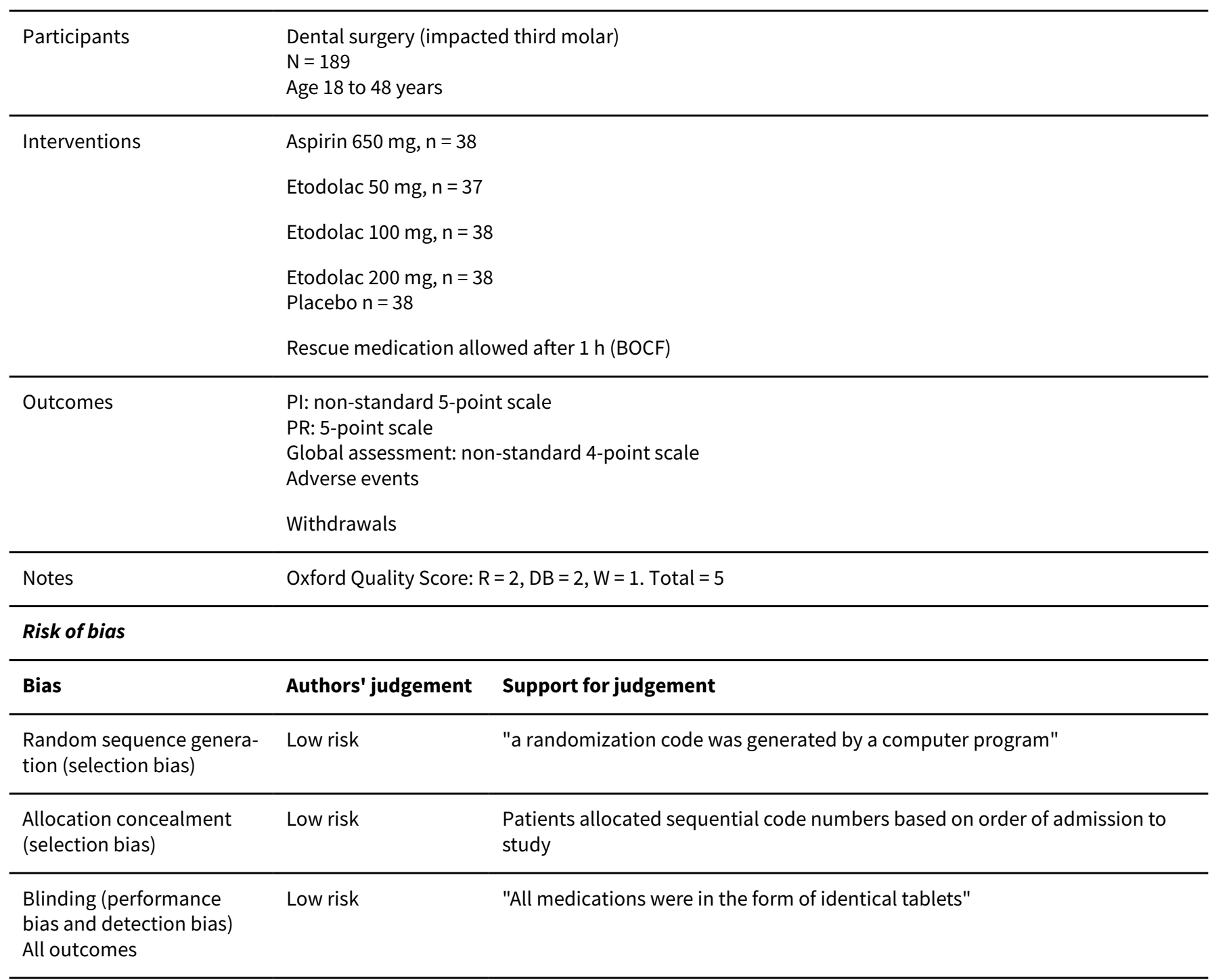


Herbertson 1994

Methods $\quad$ RCT, DB, single oral dose, parallel groups

Assessed at 0, 0.5, $1 \mathrm{~h}$ then hourly to $8 \mathrm{~h}$

\begin{tabular}{ll}
\hline Participants & $\begin{array}{l}\text { Gynaecological surgery } \\
\mathrm{N}=217 \text { (209 for efficacy analyses) } \\
\text { Mean age } 43 \text { years }\end{array}$ \\
\hline Interventions & Aspirin $650 \mathrm{mg}, \mathrm{n}=53$ \\
& Diclofenac $50 \mathrm{mg}, \mathrm{n}=52$ \\
& Diclofenac $100 \mathrm{mg}, \mathrm{n}=52$ \\
& Placebo $\mathrm{n}=52$ \\
& Rescue medication allowed after $1 \mathrm{~h}$
\end{tabular}

\begin{tabular}{ll}
\hline Outcomes & PI: standard 4-point scale \\
& PR: standard 5-point scale \\
& Global assessment: standard 5-point scale \\
& Adverse events \\
& Withdrawals \\
\hline Notes & Oxford Quality Score: $\mathrm{R}=1, \mathrm{DB}=1, \mathrm{~W}=0$. Total $=2$ \\
\hline
\end{tabular}

\section{Risk of bias}

\begin{tabular}{lll}
\hline Bias & Authors' judgement & Support for judgement \\
\hline $\begin{array}{l}\text { Random sequence genera- } \\
\text { tion (selection bias) }\end{array}$ & Unclear risk & Not described \\
\hline $\begin{array}{l}\text { Allocation concealment } \\
\text { (selection bias) }\end{array}$ & Unclear risk & Not described \\
\hline
\end{tabular}

Blinding (performance Unclear risk Not described

bias and detection bias)

All outcomes

\section{Herrmann 1980a}

\begin{tabular}{ll}
\hline Methods & $\begin{array}{l}\text { RCT, DB, single oral dose, parallel groups } \\
\text { Assessed at } 0,1,2,3,4 \mathrm{~h} \\
\text { Study } 1\end{array}$ \\
\hline Participants & $\begin{array}{l}\text { Episiotomy (not uterine cramps) } \\
\mathrm{N}=203 \\
\text { Mean age } 27 \text { years }\end{array}$ \\
\hline Interventions & Aspirin $1000 \mathrm{mg}, \mathrm{n}=50$ \\
& Fluproquazone $75 \mathrm{mg}, \mathrm{n}=52$ \\
& Fluproquazone $150 \mathrm{mg}, \mathrm{n}=51$ \\
& Placebo $\mathrm{n}=50$
\end{tabular}


Herrmann 1980a (Continued)

Rescue medication allowed after $1 \mathrm{~h}$ (LOCF)

\begin{tabular}{ll} 
Outcomes & PI: standard 4-point scale \\
& PR: standard 5-point scale \\
& Adverse events (combined for 4 studies) \\
\hline Notes & Oxford Quality Score: $\mathrm{R}=1, \mathrm{DB}=2, \mathrm{~W}=0$. Total $=$
\end{tabular}

\section{Risk of bias}

\begin{tabular}{lll}
\hline Bias & Authors' judgement & Support for judgement \\
\hline $\begin{array}{l}\text { Random sequence genera- } \\
\text { tion (selection bias) }\end{array}$ & Unclear risk & Not described \\
\hline $\begin{array}{l}\text { Allocation concealment } \\
\text { (selection bias) }\end{array}$ & Low risk & All medication "prepackaged in code-numbered individual envelopes" \\
\hline $\begin{array}{l}\text { Blinding (performance } \\
\text { bias and detection bias) } \\
\text { All outcomes }\end{array}$ & Low risk & "All capsules were identical in appearance" \\
\hline
\end{tabular}

Herrmann 1980b

\begin{tabular}{ll}
\hline Methods & RCT, DB, single oral dose, parallel groups \\
& Assessed at $0,1,2,3,4 \mathrm{~h}$ \\
& Study 2 \\
\hline Participants & Episiotomy (not uterine cramps) \\
& $\mathrm{N}=168$ \\
& Mean age 27 years \\
\hline Interventions & Aspirin $1000 \mathrm{mg}, \mathrm{n}=40$ \\
& Fluproquazone $100 \mathrm{mg}, \mathrm{n}=42$ \\
& Fluproquazone $200 \mathrm{mg}, \mathrm{n}=44$ \\
& Placebo, $\mathrm{n}=42$ \\
\hline Outcomes & Pl: standard 4-point scale \\
& PR: standard 5-point scale \\
& Adverse events (combined for 4 studies) \\
\hline Notes & Oxford Quality Score: $\mathrm{R}=1, \mathrm{DB}=2, \mathrm{~W}=0$. Total $=3$
\end{tabular}

\section{Risk of bias}

\begin{tabular}{lll}
\hline Bias & Authors' judgement & Support for judgement \\
\hline $\begin{array}{l}\text { Random sequence genera- } \\
\text { tion (selection bias) }\end{array}$ & Unclear risk & Not described \\
\hline $\begin{array}{l}\text { Allocation concealment } \\
\text { (selection bias) }\end{array}$ & Low risk & All medication "prepackaged in code-numbered individual envelopes" \\
\hline
\end{tabular}


Herrmann 1980b (Continued)

Blinding (performance Low risk_ "All capsules were identical in appearance" bias and detection bias)

All outcomes

\section{Holland 1988}

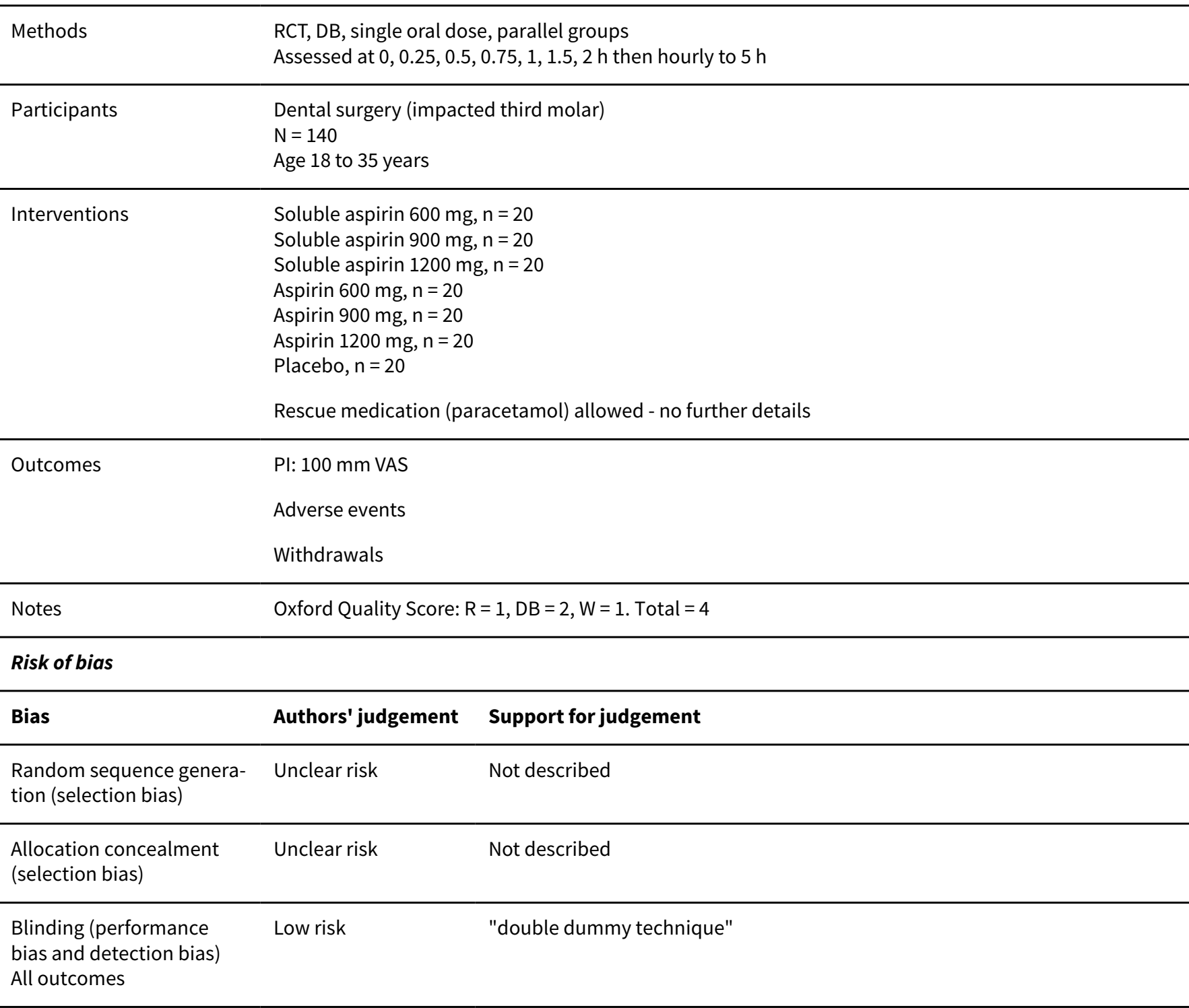

\section{Honig 1978}

Methods $\quad$ RCT, DB, single oral dose, parallel groups

Assessed at $0,1 \mathrm{~h}$ then hourly to $8 \mathrm{~h}$

$\begin{array}{ll}\text { Participants } & \text { Meniscectomy } \\ & \mathrm{N}=145 \\ & \text { Mean age } ~ 30 \text { years }\end{array}$


Honig 1978 (Continued)

$\begin{array}{ll}\text { Interventions } & \text { Aspirin } 600 \mathrm{mg}, \mathrm{n}=30 \\ & \text { Diflunisal } 125 \mathrm{mg}, \mathrm{n}=28 \\ & \text { Diflunisal } 250 \mathrm{mg}, \mathrm{n}=29 \\ & \text { Diflunisal } 500 \mathrm{mg}, \mathrm{n}=30 \\ & \text { Placebo } \mathrm{n}=28\end{array}$

Rescue medication allowed (time not specified) (participants assigned PI = severe for analysis)

\begin{tabular}{lll}
\hline Outcomes & $\begin{array}{l}\text { Pl: standard 4-point scale } \\
\text { Adverse events } \\
\end{array}$ & Withdrawals \\
\hline Notes & Oxford Quality Score: $\mathrm{R}=1, \mathrm{DB}=2, \mathrm{~W}=1$. Total $=4$ \\
\hline Risk of bias & & \\
\hline Bias & Authors' judgement & Support for judgement \\
\hline $\begin{array}{l}\text { Random sequence genera- } \\
\text { tion (selection bias) }\end{array}$ & Unclear risk & Not described \\
\hline $\begin{array}{l}\text { Allocation concealment } \\
\text { (selection bias) }\end{array}$ & Low risk & Pre-packaged in individual patient-coded vials \\
\hline $\begin{array}{l}\text { Blinding (performance } \\
\text { bias and detection bias) } \\
\begin{array}{l}\text { All outcomes } \\
\hline\end{array}\end{array}$ & Low risk & "All capsules were identical in appearance" \\
\hline
\end{tabular}

Jain 1985a

\begin{tabular}{ll} 
Methods & $\begin{array}{l}\text { RCT, DB, single oral dose, parallel groups } \\
\text { Assessed at } 0,0.5,1 \mathrm{~h} \text { then hourly to } 5 \mathrm{~h}\end{array}$ \\
\hline Participants & $\begin{array}{l}\text { Episiotomy } \\
\mathrm{N}=120 \\
\text { Mean age } 23 \text { years }\end{array}$ \\
\hline Interventions & Aspirin $600 \mathrm{mg}, \mathrm{n}=30$ \\
& Indoprofen $50 \mathrm{mg}, \mathrm{n}=30$ \\
& Indoprofen $100 \mathrm{mg}, \mathrm{n}=30$ \\
& Placebo $\mathrm{n}=30$ \\
& Rescue medication allowed (time not specified) (BOCF) \\
& Pl: standard 4-point scale \\
& PR: standard 5-point scale \\
Global assessment: non-standard 4-point scale & Rescue medication \\
Outcomes & Adverse events \\
& Withdrawals
\end{tabular}


Jain 1985a (Continued)

Notes Oxford Quality Score: $R=1, D B=2, W=1$. Total $=4$

\section{Risk of bias}

\begin{tabular}{lll}
\hline Bias & Authors' judgement & Support for judgement \\
\hline $\begin{array}{l}\text { Random sequence genera- } \\
\text { tion (selection bias) }\end{array}$ & Unclear risk & Not described \\
\hline $\begin{array}{l}\text { Allocation concealment } \\
\text { (selection bias) }\end{array}$ & Unclear risk & Not described \\
\hline $\begin{array}{l}\text { Blinding (performance } \\
\text { bias and detection bias) } \\
\text { All outcomes }\end{array}$ & Low risk & "matching capsules" \\
\hline
\end{tabular}

Jain 1985b

\begin{tabular}{ll} 
Methods & $\begin{array}{l}\text { RCT, DB, single oral dose, parallel groups } \\
\text { Assessed at } 0,0.5,1 \mathrm{~h} \text { then hourly to } 4 \mathrm{~h}\end{array}$ \\
\hline Participants & $\begin{array}{l}\text { Dental surgery (impacted third molar) } \\
\mathrm{N}=151 \text { (146 for efficacy analyses) } \\
\text { Mean age } 34 \text { years }\end{array}$
\end{tabular}

\begin{tabular}{ll}
\hline Interventions & Aspirin $600 \mathrm{mg}, \mathrm{n}=29$ \\
& Indoprofen $50 \mathrm{mg}, \mathrm{n}=29$ \\
& Indoprofen $100 \mathrm{mg}, \mathrm{n}=30$ \\
& Indoprofen $200 \mathrm{mg}, \mathrm{n}=29$ \\
& Placebo $\mathrm{n}=29$
\end{tabular}

Rescue medication allowed after $2 \mathrm{~h}$ (BOCF)

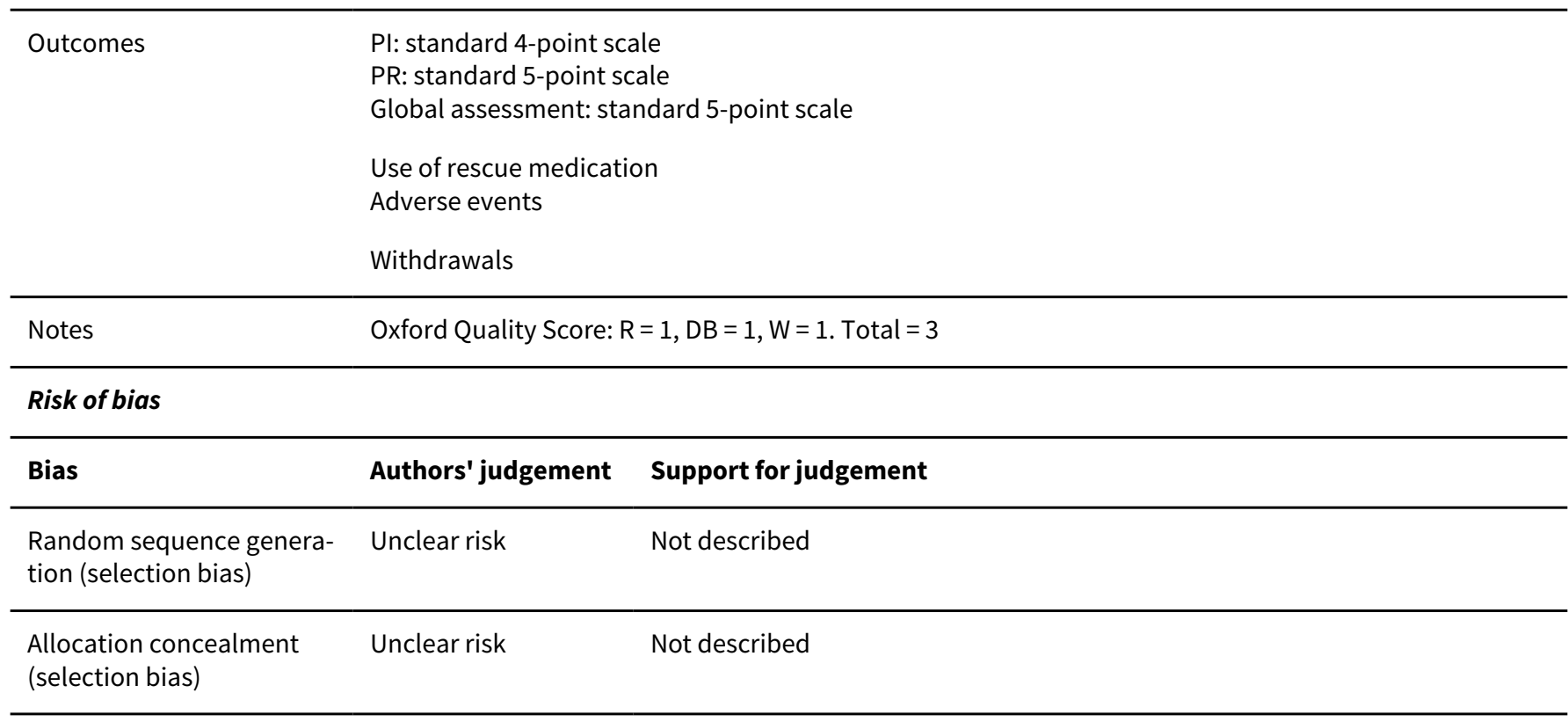


Jain 1985b (Continued)

Blinding (performance $\quad$ Unclear risk $\quad$ Not described
bias and detection bias)

All outcomes

\begin{tabular}{|c|c|}
\hline Methods & $\begin{array}{l}\mathrm{RCT}, \mathrm{DB} \text {, single oral dose, parallel groups } \\
\text { Assessed at } 0,1,2,3,4 \mathrm{~h}\end{array}$ \\
\hline Participants & $\begin{array}{l}\text { Dental surgery (impacted third molar) } \\
N=120 \\
\text { Mean age } 24 \text { years }\end{array}$ \\
\hline Interventions & $\begin{array}{l}\text { Aspirin } 600 \mathrm{mg}, \mathrm{n}=38 \\
\text { Amfenac } 100 \mathrm{mg}, \mathrm{n}=40 \\
\text { Placebo } \mathrm{n}=40 \\
\text { Rescue medication allowed after } 2 \mathrm{~h} \text { (BOCF) }\end{array}$ \\
\hline Outcomes & $\begin{array}{l}\text { PI: standard 4-point scale and } 10 \mathrm{~cm} \text { VAS } \\
\text { PR: standard 5-point scale } \\
\text { Global assessment: non-standard 4-point scale } \\
\text { Use of rescue medication } \\
\text { Adverse events } \\
\text { Withdrawals }\end{array}$ \\
\hline
\end{tabular}

Notes Oxford Quality Score: $\mathrm{R}=2, \mathrm{DB}=1, \mathrm{~W}=1$. Total $=4$

\section{Risk of bias}

\section{Bias}

Authors' judgement Support for judgement

Random sequence genera- Low risk "computer-generated random number" tion (selection bias)

\begin{tabular}{lll}
\hline $\begin{array}{l}\text { Allocation concealment } \\
\text { (selection bias) }\end{array}$ & Unclear risk & Not described \\
\hline $\begin{array}{l}\text { Blinding (performance } \\
\text { bias and detection bias) }\end{array}$ & Unclear risk & Not described \\
All outcomes & \\
\hline
\end{tabular}

\section{Jain 1986b}

\begin{tabular}{ll}
\hline Methods & RCT, DB, single oral dose, parallel groups \\
& Assessed at $0,1 \mathrm{~h}$ then hourly to $6 \mathrm{~h}$ \\
\hline Participants & $\begin{array}{l}\text { Dental surgery (impacted third molar) } \\
\mathrm{N}=241 \text { (227 for efficacy analyses) } \\
\text { Mean age } 23 \text { years }\end{array}$ \\
\hline Interventions & Aspirin $650 \mathrm{mg}, \mathrm{n}=45$ \\
\hline
\end{tabular}


Jain 1986b (Continued)

$$
\begin{aligned}
& \text { Ibuprofen } 100 \mathrm{mg}, \mathrm{n}=39 \\
& \text { Ibuprofen } 200 \mathrm{mg}, \mathrm{n}=47 \\
& \text { Ibuprofen } 400 \mathrm{mg}, \mathrm{n}=49 \\
& \text { Placebo } \mathrm{n}=47
\end{aligned}
$$

\begin{tabular}{|c|c|c|}
\hline Outcomes & $\begin{array}{l}\text { Pl: standard 4-point s } \\
\text { PR: non-standard 6-p } \\
\text { Global assessment: 5- } \\
\text { Use of rescue medicat } \\
\text { Adverse events } \\
\text { Withdrawals }\end{array}$ & $\begin{array}{l}\text { le, } 100 \mathrm{~mm} \text { VAS } \\
\text { nt scale } \\
\text { oint scale } \\
\text { on }\end{array}$ \\
\hline Notes & \multicolumn{2}{|c|}{ Oxford Quality Score: R = 2, DB $=2, W=1$. Total $=5$} \\
\hline \multicolumn{3}{|l|}{ Risk of bias } \\
\hline Bias & Authors' judgement & Support for judgement \\
\hline $\begin{array}{l}\text { Random sequence genera- } \\
\text { tion (selection bias) }\end{array}$ & Low risk & Computer-generated random number list \\
\hline $\begin{array}{l}\text { Allocation concealment } \\
\text { (selection bias) }\end{array}$ & Low risk & Bottle identified only by a sequential number \\
\hline $\begin{array}{l}\text { Blinding (performance } \\
\text { bias and detection bias) } \\
\text { All outcomes }\end{array}$ & Low risk & "identically appearing tablets" \\
\hline
\end{tabular}

Rescue medication allowed after $1 \mathrm{~h}$ (LOCF)

\section{Kempf 1987}

$\begin{array}{ll}\text { Methods } & \text { RCT, DB, single oral dose (followed by multiple dose phase), parallel groups } \\ \text { Assessed at } 0,0.5,1 \text { hourly to } 6\end{array}$

\begin{tabular}{ll}
\hline Participants & Dental surgery (impacted third molar) \\
$\mathrm{N}=105$ (98 for efficacy analysis) \\
Age 18 to 60 years
\end{tabular}


Kempf 1987 (Continued)

Withdrawals

Notes Oxford Quality Score: $R=1, D B=2, W=1$. Total $=4$

\section{Risk of bias}

\begin{tabular}{lll}
\hline Bias & Authors' judgement & Support for judgement \\
\hline $\begin{array}{l}\text { Random sequence genera- } \\
\text { tion (selection bias) }\end{array}$ & Unclear risk & Not described \\
\hline $\begin{array}{l}\text { Allocation concealment } \\
\text { (selection bias) }\end{array}$ & Unclear risk & Not described \\
\hline $\begin{array}{l}\text { Blinding (performance } \\
\text { bias and detection bias) } \\
\text { All outcomes }\end{array}$ & Low risk & "identically appearing capsules" \\
\hline
\end{tabular}

\section{Lehnert 1990}

\begin{tabular}{ll}
\hline Methods & RCT, DB, single oral dose, parallel groups \\
Assessed at $0.5,1 \mathrm{~h}$ then hourly to $6 \mathrm{~h}$
\end{tabular}

\begin{tabular}{ll}
\hline Participants & Dental surgery (impacted third molar) \\
& $\mathrm{N}=150$ (139 for efficacy analyses) \\
& Age 17 to 54 years
\end{tabular}

\begin{tabular}{ll}
\hline Interventions & Aspirin $1000 \mathrm{mg}, \mathrm{n}=45$ \\
& Paracetamol $1000 \mathrm{mg}, \mathrm{n}=49$ \\
& Placebo, $\mathrm{n}=42$ \\
& Rescue medication allowed (no further details) (BO \\
\hline Outcomes & Pl: standard 4-point scale \\
& PR: non-standard 4-point scale \\
& Global assessment: non-standard 4-point scale \\
& Use of rescue medication \\
& Adverse events \\
& Withdrawals
\end{tabular}

\begin{tabular}{ll}
\hline Notes & Language: German \\
& Oxford Quality Score: $\mathrm{R}=2, \mathrm{DB}=2, \mathrm{~W}=1$. Total $=5$
\end{tabular}

\section{Risk of bias}

\begin{tabular}{lll}
\hline Bias & Authors' judgement & Support for judgement \\
\hline $\begin{array}{l}\text { Random sequence genera- } \\
\text { tion (selection bias) }\end{array}$ & Low risk & Randomly generated \\
\hline $\begin{array}{l}\text { Allocation concealment } \\
\text { (selection bias) }\end{array}$ & Unclear risk & Not described \\
\hline
\end{tabular}


Lehnert 1990 (Continued)

Blinding (performance Low risk All capsules were identical in appearance bias and detection bias)

All outcomes

\section{London 1983a}

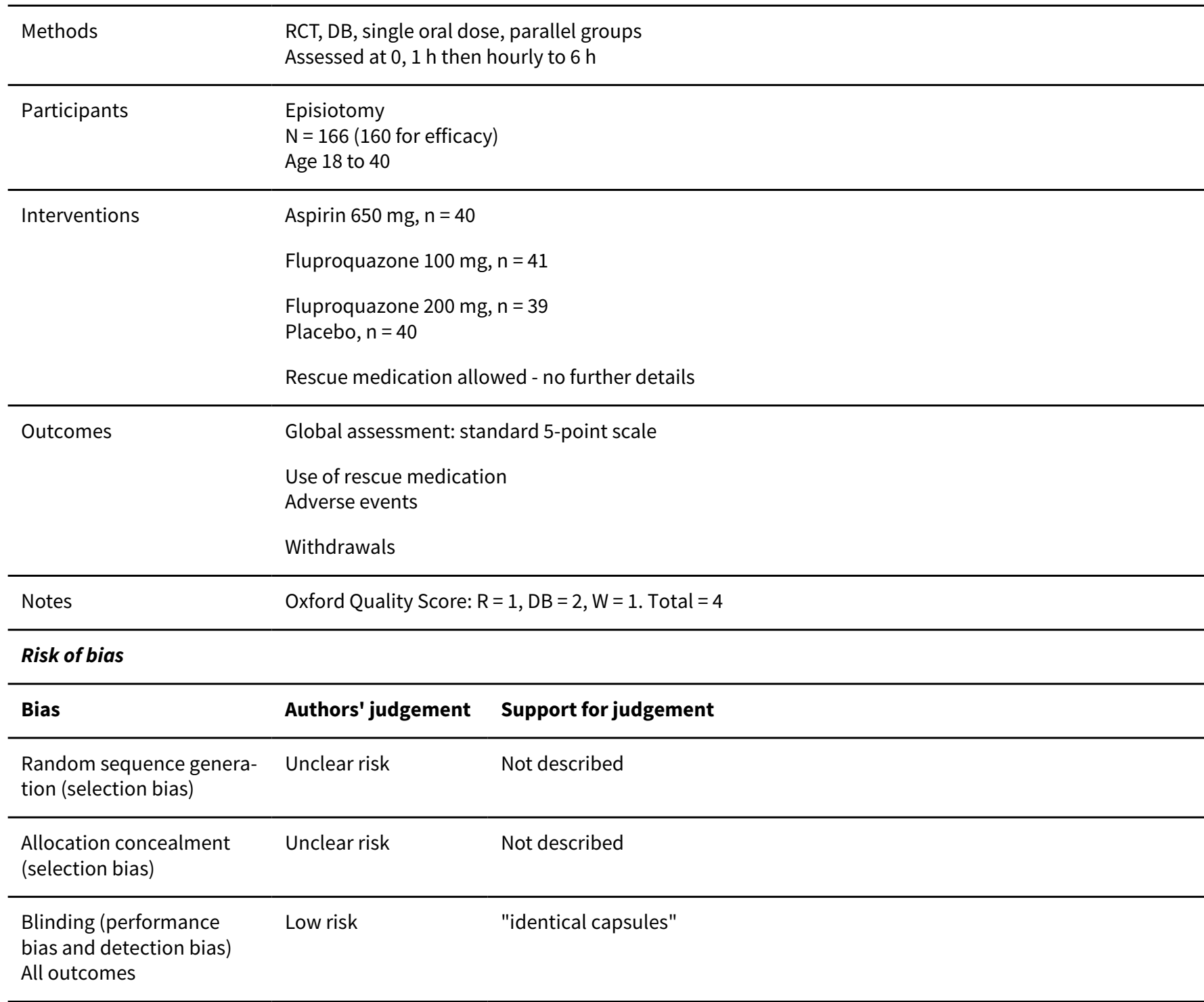

London 1983b

$\begin{array}{ll}\text { Methods } & \text { RCT, DB, single oral dose, parallel groups } \\ \text { Assessed at } 0.5,1 \mathrm{~h} \text { then hourly to } 4 \mathrm{~h}\end{array}$

\begin{tabular}{ll}
\hline Participants & Episiotomy \\
& $\mathrm{N}=160$ \\
& Age 18 to 36 years
\end{tabular}

Interventions Aspirin $300 \mathrm{mg}, \mathrm{n}=40$

Single dose oral aspirin for acute postoperative pain in adults (Review) 
London 1983b (Continued)

Aspirin $600 \mathrm{mg}, \mathrm{n}=41$

Aspirin $1200 \mathrm{mg}, \mathrm{n}=40$

Placebo, $\mathrm{n}=39$

Rescue medication allowed, data up to point of remedication used for analysis

\begin{tabular}{|c|c|c|}
\hline Outcomes & \multicolumn{2}{|c|}{$\begin{array}{l}\text { Pl: standard 4-point scale } \\
\text { Use of rescue medication } \\
\text { Adverse events }\end{array}$} \\
\hline Notes & \multicolumn{2}{|c|}{ Oxford Quality Score: $\mathrm{R}=1, \mathrm{DB}=2, \mathrm{~W}=0$. Total $=3$} \\
\hline \multicolumn{3}{|l|}{ Risk of bias } \\
\hline Bias & Authors' judgement & Support for judgement \\
\hline $\begin{array}{l}\text { Random sequence genera- } \\
\text { tion (selection bias) }\end{array}$ & Unclear risk & Not reported \\
\hline $\begin{array}{l}\text { Allocation concealment } \\
\text { (selection bias) }\end{array}$ & Low risk & $\begin{array}{l}\text { Study medication "individually packaged and identified only by study number } \\
\text { and patient number" }\end{array}$ \\
\hline $\begin{array}{l}\text { Blinding (performance } \\
\text { bias and detection bias) } \\
\text { All outcomes }\end{array}$ & Low risk & "all tablets appeared identical" \\
\hline
\end{tabular}

Mardirossian 1985

$\begin{array}{ll}\text { Methods } & \text { RCT, DB, single oral dose, parallel groups } \\ \text { Assessed at } 0.5,1 \mathrm{~h} \text { then hourly to } 6 \mathrm{~h}\end{array}$

\begin{tabular}{ll}
\hline Participants & Dental surgery (impacted third molar) \\
& $N=171$ (164 analysed) \\
Mean age 24 years
\end{tabular}

\begin{tabular}{ll}
\hline Interventions & Aspirin $650 \mathrm{mg}, \mathrm{n}=40$ \\
& Flurbiprofen $25 \mathrm{mg}, \mathrm{n}=39$ \\
& Flurbiprofen $50 \mathrm{mg}, \mathrm{n}=43$
\end{tabular}

Placebo, $n=42$

Rescue medication allowed after $1 \mathrm{~h}$ (LOCF)

\begin{tabular}{|c|c|}
\hline Outcomes & $\begin{array}{l}\text { PI: standard 4-point scale } \\
\text { PR: standard 5-point scale } \\
\text { Global assessment: non-standard 4-point scale } \\
\text { Use of rescue medication } \\
\text { Adverse events }\end{array}$ \\
\hline Notes & Oxford Quality Score: R = 1, DB = 2, W $=1$. Total $=4$ \\
\hline \multicolumn{2}{|l|}{ Risk of bias } \\
\hline Bias & Authors' judgement Support for judgement \\
\hline
\end{tabular}


Mardirossian 1985 (Continued)

\begin{tabular}{lll}
$\begin{array}{l}\text { Random sequence genera- } \\
\text { tion (selection bias) }\end{array}$ & Unclear risk & Not described \\
\hline $\begin{array}{l}\text { Allocation concealment } \\
\text { (selection bias) }\end{array}$ & Low risk & Remote allocation \\
\hline $\begin{array}{l}\text { Blinding (performance } \\
\text { bias and detection bias) } \\
\begin{array}{l}\text { All outcomes } \\
\hline\end{array}\end{array}$ & Low risk & "identically appearing medications" \\
\hline
\end{tabular}

\section{Markowitz 1985}

Methods $\quad$ RCT, DB, single oral dose (followed by multiple dose phase), parallel groups

Assessed at $0.5,1 \mathrm{~h}$ then hourly to $6 \mathrm{~h}$

\begin{tabular}{ll}
\hline Participants & Dental surgery (impacted third molar) \\
& $\mathrm{N}=225$ (205 analysed) \\
& Mean age 24 years
\end{tabular}

\begin{tabular}{|c|c|c|}
\hline \multirow[t]{4}{*}{ Interventions } & \multicolumn{2}{|c|}{ Buffered aspirin $600 \mathrm{mg}, \mathrm{n}=50$} \\
\hline & \multicolumn{2}{|c|}{ Meclofenamate $100 \mathrm{mg}, \mathrm{n}=51$} \\
\hline & \multicolumn{2}{|c|}{$\begin{array}{l}\text { Meclofenamate } 200 \text { mg, } n=51 \\
\text { Placebo, } n=53\end{array}$} \\
\hline & \multicolumn{2}{|c|}{ Rescue medication allowed after $1 \mathrm{~h}$ (BOCF) } \\
\hline \multirow[t]{5}{*}{ Outcomes } & \multirow{4}{*}{\multicolumn{2}{|c|}{$\begin{array}{l}\text { PI: standard 4-point scale } \\
\text { PR: standard 5-point scale } \\
\text { Global assessment: non-standard } \\
\text { Adverse events }\end{array}$}} \\
\hline & & \\
\hline & & \\
\hline & & \\
\hline & \multicolumn{2}{|l|}{ Withdrawals } \\
\hline Notes & \multicolumn{2}{|c|}{ Oxford Quality Score: $\mathrm{R}=2, \mathrm{DB}=1, \mathrm{~W}=1$. Total $=4$} \\
\hline \multicolumn{3}{|l|}{ Risk of bias } \\
\hline Bias & Authors' judgement & Support for judgement \\
\hline $\begin{array}{l}\text { Random sequence genera- } \\
\text { tion (selection bias) }\end{array}$ & Low risk & "computer-generated randomization code" \\
\hline $\begin{array}{l}\text { Allocation concealment } \\
\text { (selection bias) }\end{array}$ & Unclear risk & Not described \\
\hline $\begin{array}{l}\text { Blinding (performance } \\
\text { bias and detection bias) } \\
\text { All outcomes }\end{array}$ & Unclear risk & Not described \\
\hline
\end{tabular}

McQuay 1987

Methods RCT, DB, single oral dose, parallel groups


McQuay 1987 (Continued)

Assessed at $0.5,1,1.5,2, \mathrm{~h}$ then hourly to $6 \mathrm{~h}$

\begin{tabular}{|c|c|c|}
\hline \multirow{2}{*}{$\begin{array}{l}\text { Participants } \\
\text { Interventions }\end{array}$} & \multicolumn{2}{|l|}{$\begin{array}{l}\text { Orthopaedic surgery } \\
N=120 \\
\text { Age } 18 \text { to } 70 \text { years }\end{array}$} \\
\hline & \multicolumn{2}{|c|}{$\begin{array}{l}\text { Aspirin } 650 \mathrm{mg}, \mathrm{n}=30 \\
\text { Fluradoline } 150 \mathrm{mg}, \mathrm{n}=30 \\
\text { Fluradoline } 300 \mathrm{mg}, \mathrm{n}=30 \\
\text { Placebo, } \mathrm{n}=30 \\
\text { Rescue medication allowed after } 1 \mathrm{~h} \text { (BOCF) }\end{array}$} \\
\hline Outcomes & $\begin{array}{l}\text { PI: standard 4-point sc } \\
\text { PR: standard 5-point s } \\
\text { Global assessment: st } \\
\text { Use of rescue medicat } \\
\text { Adverse events } \\
\text { Withdrawals }\end{array}$ & $\begin{array}{l}\text { le, } 100 \mathrm{~mm} \text { VAS } \\
\text { ale, } 100 \mathrm{~mm} \text { VAS } \\
\text { adard 5-point scale } \\
\text { on }\end{array}$ \\
\hline Notes & \multicolumn{2}{|c|}{ Oxford Quality Score: R = 1, DB = 2, W $=1$. Total $=4$} \\
\hline \multicolumn{3}{|l|}{ Risk of bias } \\
\hline Bias & Authors' judgement & Support for judgement \\
\hline $\begin{array}{l}\text { Random sequence genera- } \\
\text { tion (selection bias) }\end{array}$ & Unclear risk & Not described \\
\hline $\begin{array}{l}\text { Allocation concealment } \\
\text { (selection bias) }\end{array}$ & Unclear risk & Not described \\
\hline $\begin{array}{l}\text { Blinding (performance } \\
\text { bias and detection bias) } \\
\text { All outcomes }\end{array}$ & Low risk & All capsules "identical in external appearance" \\
\hline
\end{tabular}

Mehlisch 1984

\begin{tabular}{ll}
\hline Methods & $\begin{array}{l}\text { RCT, DB, single oral dose, parallel groups } \\
\text { Assessed at } 0.5,1 \mathrm{~h} \text { then hourly to } 6 \mathrm{~h}\end{array}$ \\
\hline Participants & $\begin{array}{l}\text { Dental surgery (impacted third molar) } \\
\mathrm{N}=162 \\
\text { Age } 16 \text { to } 78 \text { years }\end{array}$ \\
\hline Interventions & Aspirin $650 \mathrm{mg}, \mathrm{n}=49$ \\
& $\begin{array}{l}\text { Paracetamol } 1000 \mathrm{mg}, \mathrm{n}=58 \\
\text { Placebo, } \mathrm{n}=55\end{array}$ \\
& Rescue medication allowed after $1 \mathrm{~h}$ (BOCF) \\
\hline Outcomes & Pl: standard 4-point scale
\end{tabular}


PR: standard 5-point scale

Global assessment: standard 5-point scale

Use of rescue medication

Withdrawals

Notes Oxford Quality Score: $R=1, D B=2, W=1$. Total $=4$

\section{Risk of bias}

\begin{tabular}{lll}
\hline Bias & Authors' judgement & Support for judgement \\
\hline $\begin{array}{l}\text { Random sequence genera- } \\
\text { tion (selection bias) }\end{array}$ & Unclear risk & Not described \\
\hline $\begin{array}{l}\text { Allocation concealment } \\
\text { (selection bias) }\end{array}$ & Unclear risk & Not described \\
\hline $\begin{array}{l}\text { Blinding (performance } \\
\text { bias and detection bias) } \\
\text { All outcomes }\end{array}$ & Low risk & "capsules were identical in appearance" \\
\hline
\end{tabular}

Mehlisch 1990

$\begin{array}{ll}\text { Methods } & \text { RCT, DB, single oral dose, parallel groups } \\ \text { Assessed at } 0.5,1 \mathrm{~h} \text { then hourly to } 6 \mathrm{~h}\end{array}$

\begin{tabular}{ll}
\hline Participants & Dental surgery (impacted third molar) \\
& $\mathrm{N}=161$ \\
& Mean age 24 years
\end{tabular}

\begin{tabular}{ll}
\hline Interventions & Aspirin $650 \mathrm{mg}, \mathrm{n}=40$ \\
& FS205-397 250 mg, $\mathrm{n}=40$ \\
& FS205-397 500 mg, $\mathrm{n}=40$ \\
& Placebo, $\mathrm{n}=41$
\end{tabular}

\begin{tabular}{ll}
\hline Outcomes & PI: standard 4-point scale \\
PR: standard 5-point scale \\
Global assessment: 5-point scale \\
Use of rescue medication \\
Adverse events \\
Withdrawals
\end{tabular}

\begin{tabular}{|c|c|c|}
\hline Notes & Oxford Quality Score: & $=2, \mathrm{DB}=2, \mathrm{~W}=1$. Total $=5$ \\
\hline \multicolumn{3}{|l|}{ Risk of bias } \\
\hline Bias & Authors' judgement & Support for judgement \\
\hline $\begin{array}{l}\text { Random sequence genera- } \\
\text { tion (selection bias) }\end{array}$ & Low risk & "computer-derived randomization schedule" \\
\hline
\end{tabular}


Mehlisch 1990 (Continued)

\begin{tabular}{lll}
$\begin{array}{l}\text { Allocation concealment } \\
\text { (selection bias) }\end{array}$ & Unclear risk & Not described \\
\hline $\begin{array}{l}\text { Blinding (performance } \\
\text { bias and detection bias) } \\
\text { All outcomes }\end{array}$ & Low risk & "identically appearing two-capsule doses"
\end{tabular}

\section{Mehlisch 1994}

\begin{tabular}{ll}
\hline Methods & RCT, DB, single oral dose, parallel groups \\
Assessed at $0.5,1 \mathrm{~h}$ then hourly to $8 \mathrm{~h}$
\end{tabular}

\begin{tabular}{|c|c|c|}
\hline Participants & \multicolumn{2}{|c|}{$\begin{array}{l}\text { Dental surgery (impacted third molar) } \\
N=208 \\
\text { Age } 20 \text { to } 90 \text { years }\end{array}$} \\
\hline Interventions & \multicolumn{2}{|c|}{$\begin{array}{l}\text { Aspirin } 650 \mathrm{mg}, \mathrm{n}=51 \\
\text { Diclofenac } 50 \mathrm{mg}, \mathrm{n}=53 \\
\begin{array}{l}\text { Diclofenac } 100 \mathrm{mg}, \mathrm{n}=52 \\
\text { placebo, } \mathrm{n}=52\end{array}\end{array}$} \\
\hline Outcomes & $\begin{array}{l}\text { PI: standard 4-point sc } \\
\text { PR: standard 5-point s } \\
\text { Global assessment: no } \\
\text { Use of rescue medicat } \\
\text { Adverse events } \\
\text { Withdrawals }\end{array}$ & $\begin{array}{l}\text { le } \\
\text { ale } \\
\text {-standard 3-point scale }\end{array}$ \\
\hline Notes & \multicolumn{2}{|c|}{ Oxford Quality Score: R = 1, DB = 1, W = 1. Total $=3$} \\
\hline \multicolumn{3}{|l|}{ Risk of bias } \\
\hline Bias & Authors' judgement & Support for judgement \\
\hline $\begin{array}{l}\text { Random sequence genera- } \\
\text { tion (selection bias) }\end{array}$ & Unclear risk & Not described \\
\hline $\begin{array}{l}\text { Allocation concealment } \\
\text { (selection bias) }\end{array}$ & Unclear risk & Not described \\
\hline $\begin{array}{l}\text { Blinding (performance } \\
\text { bias and detection bias) } \\
\text { All outcomes }\end{array}$ & Unclear risk & Not described \\
\hline
\end{tabular}

\section{Nelson 1985}

$\begin{array}{ll}\text { Methods } & \text { RCT, DB, single oral dose, parallel groups } \\ \text { Assessed at } 0.5,1 \mathrm{~h} \text { then hourly to } 12 \mathrm{~h}\end{array}$

Assessed at $0.5,1 \mathrm{~h}$ then hourly to $12 \mathrm{~h}$

Participants Dental surgery (impacted third molar)

Single dose oral aspirin for acute postoperative pain in adults (Review) 
Nelson 1985 (Continued)

$\mathrm{N}=207$ (201 for analyses)

Age 17 to 45 years

\begin{tabular}{|c|c|c|}
\hline \multirow[t]{5}{*}{ Interventions } & \multirow{2}{*}{\multicolumn{2}{|c|}{$\begin{array}{l}\text { Aspirin } 650 \mathrm{mg}, \mathrm{n}=40 \\
\text { Etodolac } 50 \mathrm{mg}, \mathrm{n}=41\end{array}$}} \\
\hline & & \\
\hline & \multicolumn{2}{|l|}{ Etodolac $100 \mathrm{mg}, \mathrm{n}=42$} \\
\hline & \multicolumn{2}{|c|}{$\begin{array}{l}\text { Etodolac } 200 \mathrm{mg}, \mathrm{n}=39 \\
\text { Placebo, } \mathrm{n}=39\end{array}$} \\
\hline & \multicolumn{2}{|c|}{ Rescue medication allowed (time not specified) (BOCF) } \\
\hline Outcomes & \multicolumn{2}{|c|}{$\begin{array}{l}\text { PI: non-standard 5-point scale } \\
\text { PR: 5-point scale } \\
\text { Global assessment: non-standard 4-point scale } \\
\text { Withdrawals }\end{array}$} \\
\hline Notes & \multicolumn{2}{|c|}{ Oxford Quality Score: $R=1, D B=2, W=1$. Total $=4$} \\
\hline \multicolumn{3}{|l|}{ Risk of bias } \\
\hline Bias & Authors' judgement & Support for judgement \\
\hline $\begin{array}{l}\text { Random sequence genera- } \\
\text { tion (selection bias) }\end{array}$ & Unclear risk & Not described \\
\hline $\begin{array}{l}\text { Allocation concealment } \\
\text { (selection bias) }\end{array}$ & Unclear risk & Not described \\
\hline $\begin{array}{l}\text { Blinding (performance } \\
\text { bias and detection bias) } \\
\text { All outcomes }\end{array}$ & Low risk & "two tablets which appeared identical" \\
\hline
\end{tabular}

\section{Nelson 1994a}

\begin{tabular}{ll}
\hline Methods & $\begin{array}{l}\text { RCT, DB, single oral dose, parallel groups } \\
\text { Assessed at } 0.25,0.5,0.75,1,1.5,2 \mathrm{~h} \text { then hourly to } 6 \mathrm{~h}\end{array}$ \\
\hline Participants & $\begin{array}{l}\text { Dental surgery (impacted third molar) } \\
\mathrm{N}=183 \text { (180 for efficacy analyses) } \\
\text { Age } 15 \text { to } 52 \text { years }\end{array}$ \\
\hline Interventions & Aspirin $500 \mathrm{mg}, \mathrm{n}=65$ \\
& Ibuprofen lysine $200 \mathrm{mg}, \mathrm{n}=77$ \\
& Placebo, $\mathrm{n}=41$ \\
& Rescue medication allowed after $1 \mathrm{~h}$ (BOCF)
\end{tabular}

\section{Outcomes}

PI: standard 4-point scale

PR: standard 5-point scale

Global assessment: standard 5-point scale

Use of rescue medication

Adverse events 
Nelson 1994a (Continued)

Withdrawals

Notes Oxford Quality Score: $\mathrm{R}=2, \mathrm{DB}=2, \mathrm{~W}=1$. Total $=5$

\section{Risk of bias}

\begin{tabular}{lll}
\hline Bias & Authors' judgement & Support for judgement \\
\hline $\begin{array}{l}\text { Random sequence genera- } \\
\text { tion (selection bias) }\end{array}$ & Unclear risk & "allocation schedule of random numbers" \\
\hline $\begin{array}{l}\text { Allocation concealment } \\
\text { (selection bias) }\end{array}$ & Unclear risk & Not described \\
\hline $\begin{array}{l}\text { Blinding (performance } \\
\text { bias and detection bias) } \\
\text { All outcomes }\end{array}$ & Low risk & Double-dummy method \\
\hline
\end{tabular}

Nelson 1994b

\begin{tabular}{ll}
\hline Methods & $\begin{array}{l}\text { RCT, DB, single oral dose, parallel groups } \\
\text { Assessed at } 0.5,1 \mathrm{~h} \text { then hourly to } 8 \mathrm{~h}\end{array}$ \\
\hline Participants & $\begin{array}{l}\text { Dental surgery (impacted third molar) } \\
\mathrm{N}=255 \text { (252 for analyses) } \\
\text { Age } 16 \text { to } 70 \text { years }\end{array}$ \\
\hline Interventions & Aspirin $650 \mathrm{mg}, \mathrm{n}=51$ \\
& Diclofenac $25 \mathrm{mg}, \mathrm{n}=51$ \\
& Diclofenac $50 \mathrm{mg}, \mathrm{n}=51$ \\
& Diclofenac $100 \mathrm{mg}, \mathrm{n}=51$ \\
& Placebo, $\mathrm{n}=51$ \\
& Rescue medication allowed after $1 \mathrm{~h}$ - no further details
\end{tabular}

\begin{tabular}{|c|c|c|}
\hline Outcomes & $\begin{array}{l}\text { PI: standard 4-point sc } \\
\text { PR: 5-point scale } \\
\text { Use of rescue medicat } \\
\text { Adverse events }\end{array}$ & \\
\hline Notes & \multicolumn{2}{|c|}{ Oxford Quality Score: R = 1, DB $=2, W=0$. Total $=3$} \\
\hline \multicolumn{3}{|l|}{ Risk of bias } \\
\hline Bias & Authors' judgement & Support for judgement \\
\hline $\begin{array}{l}\text { Random sequence genera- } \\
\text { tion (selection bias) }\end{array}$ & Unclear risk & Not described \\
\hline $\begin{array}{l}\text { Allocation concealment } \\
\text { (selection bias) }\end{array}$ & Unclear risk & Not described \\
\hline
\end{tabular}


Nelson 1994b (Continued)

Blinding (performance bias and detection bias)

All outcomes

\section{Olsen 1997}

\begin{tabular}{|c|c|}
\hline Methods & $\begin{array}{l}\mathrm{RCT}, \mathrm{DB} \text {, single oral dose, parallel groups. } \\
\text { Medication administered when baseline pain was of moderate to severe intensity } \\
\text { Pain assessed at } 0,0.5,1 \mathrm{~h} \text {, then hourly to } 8 \mathrm{~h}\end{array}$ \\
\hline Participants & $\begin{array}{l}\text { Episiotomy } \\
\mathrm{N}=255 \\
\text { All } \mathrm{F} \\
\text { Mean age } 24 \text { years }\end{array}$ \\
\hline Interventions & $\begin{array}{l}\text { Aspirin } 650 \mathrm{mg}, \mathrm{n}=50 \\
\text { Diclofenac K } 25 \mathrm{mg}, \mathrm{n}=52 \\
\text { Diclofenac K } 50 \mathrm{mg}, \mathrm{n}=50 \\
\text { Diclofenac K } 100 \mathrm{mg}, \mathrm{n}=51 \\
\text { Placebo, } \mathrm{n}=52 \\
\text { Rescue medication (non-study analgesic) allowed after } 1 \mathrm{~h}\end{array}$ \\
\hline Outcomes & $\begin{array}{l}\text { PI: standard 4-point scale } \\
\text { PR: standard 5-point scale } \\
\text { Global assessment: non-standard 4-point scale } \\
\text { Use of rescue medication } \\
\text { Adverse events } \\
\text { Withdrawals }\end{array}$ \\
\hline
\end{tabular}

Notes Oxford Quality Score: $\mathrm{R}=2, \mathrm{DB}=2, \mathrm{~W}=1$. Total $=5$

\section{Risk of bias}

\begin{tabular}{lll}
\hline Bias & Authors' judgement & Support for judgement \\
\hline $\begin{array}{l}\text { Random sequence genera- } \\
\text { tion (selection bias) }\end{array}$ & Unclear risk & Computer-generated \\
\hline $\begin{array}{l}\text { Allocation concealment } \\
\text { (selection bias) }\end{array}$ & Unclear risk & Not described \\
\hline $\begin{array}{l}\text { Blinding (performance } \\
\text { bias and detection bias) } \\
\text { All outcomes }\end{array}$ & Low risk & Double-dummy technique \\
\hline
\end{tabular}




\begin{tabular}{|c|c|c|}
\hline Participants & \multicolumn{2}{|c|}{$\begin{array}{l}\text { Dental surgery (impacted third molar) } \\
N=120 \\
\text { Mean age } 26 \text { years }\end{array}$} \\
\hline Interventions & \multicolumn{2}{|c|}{$\begin{array}{l}\text { Aspirin } 650 \mathrm{mg}, \mathrm{n}=27 \\
\text { Mefenamic acid } 250 \mathrm{mg}, \mathrm{n}=27 \\
\text { Mefenamic acid } 250 \mathrm{mg} \text { plus aspirin } 650 \mathrm{mg}, \mathrm{n}=27 \\
\text { Placebo, } \mathrm{n}=27\end{array}$} \\
\hline Outcomes & \multicolumn{2}{|c|}{$\begin{array}{l}\text { PI: non-standard 5-point scale, } 100 \text { mm VAS } \\
\text { PR: standard 5-point scale } \\
\text { Adverse events } \\
\text { Withdrawals }\end{array}$} \\
\hline Notes & \multicolumn{2}{|c|}{ Oxford Quality Score: $R=1, D B=2, W=1$. Total $=4$} \\
\hline \multicolumn{3}{|l|}{ Risk of bias } \\
\hline Bias & Authors' judgement & Support for judgement \\
\hline $\begin{array}{l}\text { Random sequence genera- } \\
\text { tion (selection bias) }\end{array}$ & Unclear risk & Not described \\
\hline $\begin{array}{l}\text { Allocation concealment } \\
\text { (selection bias) }\end{array}$ & Unclear risk & Not described \\
\hline $\begin{array}{l}\text { Blinding (performance } \\
\text { bias and detection bias) } \\
\text { All outcomes }\end{array}$ & Low risk & "identically-appearing two-capsule doses" \\
\hline
\end{tabular}

Parkhouse 1969

\begin{tabular}{ll}
\hline Methods & RCT, DB, single oral dose, parallel groups \\
Assessed at $0.0 .5,1 \mathrm{~h}$ then hourly to $6 \mathrm{~h}$
\end{tabular}

\begin{tabular}{ll}
\hline Participants & Postoperative pain \\
\hline Interventions & Hospital A \\
& Aspirin fast-buffered $600 \mathrm{mg}, \mathrm{n}=45$ \\
& Aspirin standard tablets $600 \mathrm{mg}, \mathrm{n}=45$ \\
& Placebo, $\mathrm{n}=46$ \\
& Hospital B \\
& Aspirin fast-buffered $600 \mathrm{mg}, \mathrm{n}=42$
\end{tabular}


Parkhouse 1969 (Continued)

Aspirin standard tablets $600 \mathrm{mg}, \mathrm{n}=37$

Placebo, $\mathrm{n}=39$

Rescue medication allowed at any time

\begin{tabular}{|c|c|c|}
\hline \multirow[t]{4}{*}{ Outcomes } & \multicolumn{2}{|c|}{ PI: standard 4-point scale } \\
\hline & \multicolumn{2}{|c|}{ Use of rescue medication } \\
\hline & \multicolumn{2}{|l|}{ Adverse events } \\
\hline & \multicolumn{2}{|l|}{ Withdrawals } \\
\hline Notes & \multicolumn{2}{|c|}{ Oxford Quality Score: $R=1, D B=2, W=1$. Total $=4$} \\
\hline \multicolumn{3}{|l|}{ Risk of bias } \\
\hline Bias & Authors' judgement & Support for judgement \\
\hline $\begin{array}{l}\text { Random sequence genera- } \\
\text { tion (selection bias) }\end{array}$ & Unclear risk & Not described \\
\hline $\begin{array}{l}\text { Allocation concealment } \\
\text { (selection bias) }\end{array}$ & Unclear risk & Not described \\
\hline $\begin{array}{l}\text { Blinding (performance } \\
\text { bias and detection bias) } \\
\text { All outcomes }\end{array}$ & Low risk & "identically formulated" \\
\hline
\end{tabular}

Patel 1991

$\begin{array}{ll}\text { Methods } & \text { RCT, DB, single oral dose, parallel groups } \\ \text { Assessed at } 0.5,1 \mathrm{~h} \text { then hourly to } 8 \mathrm{~h}\end{array}$

\begin{tabular}{ll}
\hline Participants & $\begin{array}{l}\text { Dental surgery (impacted third molar) } \\
\mathrm{N}=150 \\
\text { Mean age } 24 \text { years }\end{array}$ \\
\hline Interventions & Aspirin $650 \mathrm{mg}, \mathrm{n}=30$ \\
& Lornoxicam $2 \mathrm{mg}, \mathrm{n}=30$ \\
& Lornoxicam $4 \mathrm{mg}, \mathrm{n}=30$ \\
& Lornoxicam $8 \mathrm{mg}, \mathrm{n}=30$ \\
& Placebo, $\mathrm{n}=30$ \\
& Rescue medication allowed at any time (LOCF) \\
Pl: standard 4-point scale & PR: standard 5-point scale \\
Global assessment: standard 5-point scale \\
Adverse events \\
Withdrawals
\end{tabular}

Notes Oxford Quality Score: $\mathrm{R}=1, \mathrm{DB}=1, \mathrm{~W}=1$. Total $=3$


Patel 1991 (Continued)

Risk of bias

\begin{tabular}{lll}
\hline Bias & Authors' judgement & Support for judgement \\
\hline $\begin{array}{l}\text { Random sequence genera- } \\
\text { tion (selection bias) }\end{array}$ & Unclear risk & Not described \\
\hline $\begin{array}{l}\text { Allocation concealment } \\
\text { (selection bias) }\end{array}$ & Unclear risk & Not described \\
\hline $\begin{array}{l}\text { Blinding (performance } \\
\text { bias and detection bias) } \\
\text { All outcomes }\end{array}$ & Unclear risk & Not described \\
\hline
\end{tabular}

\section{Rowe 1985}

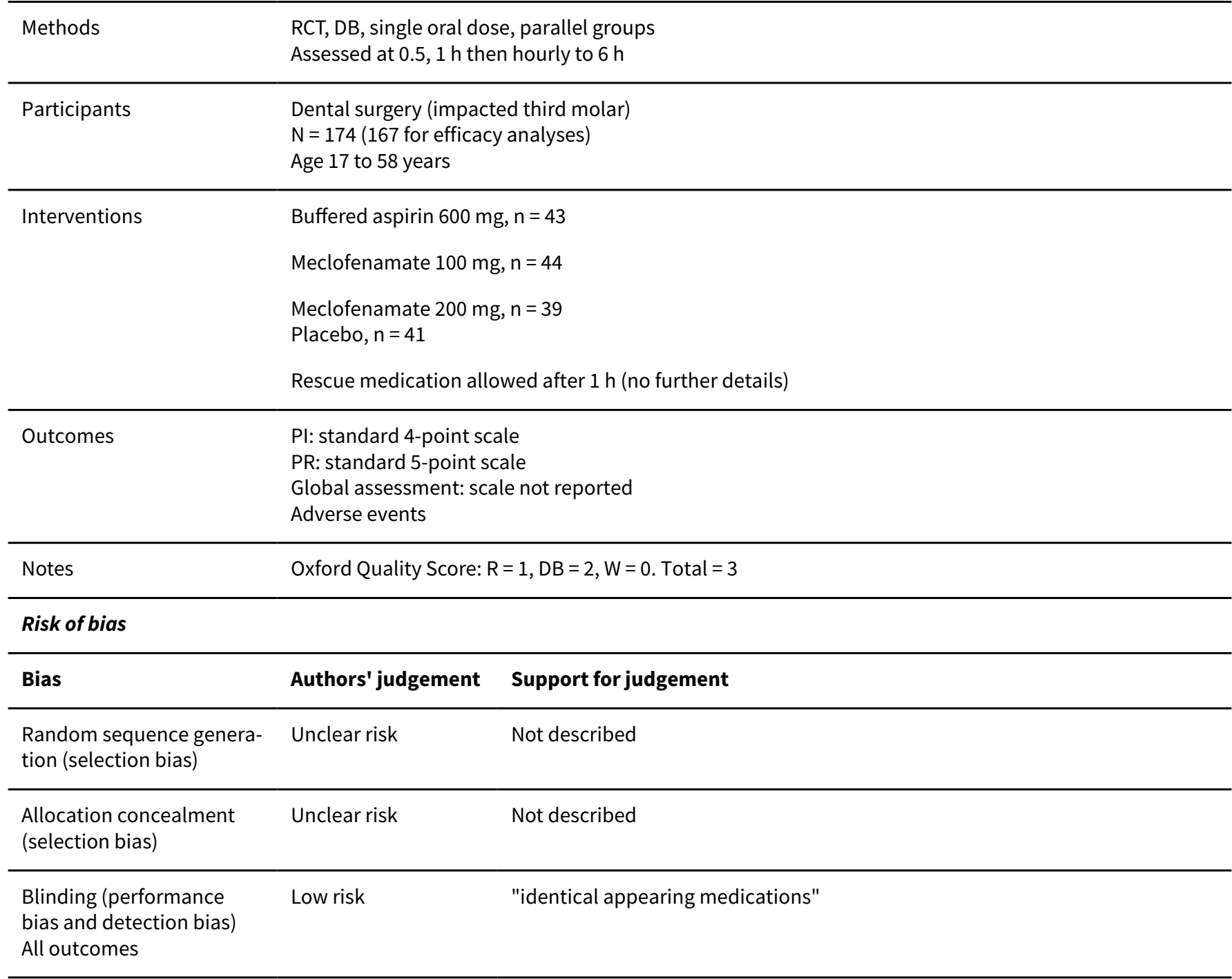


Seymour 1986

\begin{tabular}{|c|c|}
\hline Methods & $\begin{array}{l}\text { RCT, DB, single oral dose, parallel groups } \\
\text { Assessed at } 0.25,0.5,0.45,1,1.5,2 \mathrm{~h} \text { then hourly to } 5 \mathrm{~h}\end{array}$ \\
\hline Participants & $\begin{array}{l}\text { Dental surgery (impacted third molar) } \\
\mathrm{N}=90 \\
\text { Age } 17 \text { to } 40 \text { years }\end{array}$ \\
\hline Interventions & $\begin{array}{l}\text { Soluble aspirin } 1200 \mathrm{mg}, \mathrm{n}=30 \\
\text { Aspirin tablets } 1200 \mathrm{mg}, \mathrm{n}=30 \\
\text { Placebo, } \mathrm{n}=30\end{array}$ \\
\hline Outcomes & PI: $100 \mathrm{~mm}$ VAS \\
\hline Notes & Oxford Quality Score: R= 1, DB = 2, W $=0$. Total $=3$ \\
\hline Risk of bias & \\
\hline Bias & Authors' judgement Support for judgement \\
\hline $\begin{array}{l}\text { Random sequence genera- } \\
\text { tion (selection bias) }\end{array}$ & Not described \\
\hline $\begin{array}{l}\text { Allocation concealment } \\
\text { (selection bias) }\end{array}$ & Not described \\
\hline $\begin{array}{l}\text { Blinding (performance } \\
\text { bias and detection bias) } \\
\text { All outcomes }\end{array}$ & "double-dummy technique" \\
\hline
\end{tabular}

Seymour 1992

\begin{tabular}{ll}
\hline Methods & RCT, DB, single oral dose, parallel groups \\
& Assessed at $0.25,0.5,0.75,1,1.5,2 \mathrm{~h}$ then hourly to $5 \mathrm{~h}$ \\
\hline Participants & Dental surgery (impacted third molar) \\
& $\mathrm{N}=182$ \\
& Mean age 26 years \\
\hline Interventions & Buffered aspirin $500 \mathrm{mg}, \mathrm{n}=35$ \\
& Buffered aspirin $1000 \mathrm{mg}, \mathrm{n}=38$ \\
& Aspirin tablets $500 \mathrm{mg}, \mathrm{n}=35$ \\
& $\begin{array}{l}\text { Aspirin tablets } 1000 \mathrm{mg}, \mathrm{n}=37 \\
\text { Placebo, } \mathrm{n}=37 \\
\text { Rescue medication allowed (LOCF) }\end{array}$ \\
\hline Outcomes & PI: 100 mm VAS \\
Global assessment: 5 -point scale \\
Use of rescue medication
\end{tabular}

\section{Risk of bias}


Seymour 1992 (Continued)

\begin{tabular}{lll} 
Bias & Authors' judgement & Support for judgement \\
\hline $\begin{array}{l}\text { Random sequence genera- } \\
\text { tion (selection bias) }\end{array}$ & Unclear risk & Not described \\
\hline $\begin{array}{l}\text { Allocation concealment } \\
\text { (selection bias) }\end{array}$ & Unclear risk & Not described \\
\hline $\begin{array}{l}\text { Blinding (performance } \\
\text { bias and detection bias) } \\
\text { All outcomes }\end{array}$ & Low risk & "double-dummy technique" \\
\hline
\end{tabular}

\section{Seymour 2003}

\begin{tabular}{ll}
\hline Methods & RCT, DB, single oral dose, parallel groups \\
& Assessed at $0,0.08,0.17,0.25,0.33,0.5,0.75,1,1.5,2 \mathrm{~h}$ \\
\hline Participants & Dental surgery (impacted third molar) \\
& $\mathrm{N}=153$ \\
& Mean age 25 years
\end{tabular}

\begin{tabular}{ll}
\hline Interventions & Soluble aspirin $900 \mathrm{mg}, \mathrm{n}=59$ \\
& Paracetamol tablets $1000 \mathrm{mg}, \mathrm{n}=62$ \\
& Placebo, $\mathrm{n}=32$ \\
& Rescue medication (ibuprofen $400 \mathrm{mg}$ ) allowed after $1 \mathrm{~h}$ (LOCF) \\
\hline Outcomes & Pl: 100 mm VAS \\
& Global assessment: 5-point scale \\
& Use of rescue medication \\
& Adverse events \\
& Withdrawals
\end{tabular}

Notes Oxford Quality Score: $\mathrm{R}=1, \mathrm{DB}=2, \mathrm{~W}=1$. Total $=4$

\section{Risk of bias}

\begin{tabular}{lll}
\hline Bias & Authors' judgement & Support for judgement \\
\hline $\begin{array}{l}\text { Random sequence genera- } \\
\text { tion (selection bias) }\end{array}$ & Unclear risk & Not described \\
\hline $\begin{array}{l}\text { Allocation concealment } \\
\text { (selection bias) }\end{array}$ & Unclear risk & Not described \\
\hline $\begin{array}{l}\text { Blinding (performance } \\
\text { bias and detection bias) } \\
\text { All outcomes }\end{array}$ & Low risk & "double-dummy method" \\
\hline
\end{tabular}


Sunshine 1983a

\begin{tabular}{|c|c|c|}
\hline Methods & \multicolumn{2}{|c|}{$\begin{array}{l}\mathrm{RCT}, \mathrm{DB} \text {, single oral dose, parallel groups } \\
\text { Assessed at } 0,0.5,1 \mathrm{~h} \text { then hourly to } 6 \mathrm{~h}\end{array}$} \\
\hline Participants & \multicolumn{2}{|c|}{$\begin{array}{l}\text { Dental surgery (impacted third molars) } \\
N=148 \\
\text { Mean age } 23 \text { years }\end{array}$} \\
\hline Interventions & \multicolumn{2}{|c|}{$\begin{array}{l}\text { Aspirin } 650 \mathrm{mg}, \mathrm{n}=41 \\
\text { Aspirin } 650 \mathrm{mg} \text { + codeine } 60 \mathrm{mg}, \mathrm{n}=41 \\
\text { Suprofen } 200 \mathrm{mg}, \mathrm{n}=40 \\
\text { Suprofen } 400 \mathrm{mg}, \mathrm{n}=41 \\
\text { Placebo, } \mathrm{n}=40 \\
\text { Rescue medication allowed after } 2 \mathrm{~h} \text { (LOCF) }\end{array}$} \\
\hline Outcomes & $\begin{array}{l}\text { PI: standard 4-point sc } \\
\text { PR: standard 5-point s } \\
\text { Global assessment: sta } \\
\text { Use of rescue medicat } \\
\text { Adverse events } \\
\text { Withdrawals }\end{array}$ & $\begin{array}{l}\text { le } \\
\text { ale } \\
\text { adard 5-point scale }\end{array}$ \\
\hline Notes & \multicolumn{2}{|c|}{ Oxford Quality Score: R = 1, DB $=2, W=1$. Total $=4$} \\
\hline \multicolumn{3}{|l|}{ Risk of bias } \\
\hline Bias & Authors' judgement & Support for judgement \\
\hline $\begin{array}{l}\text { Random sequence genera- } \\
\text { tion (selection bias) }\end{array}$ & Unclear risk & Not described \\
\hline $\begin{array}{l}\text { Allocation concealment } \\
\text { (selection bias) }\end{array}$ & Unclear risk & Not described \\
\hline $\begin{array}{l}\text { Blinding (performance } \\
\text { bias and detection bias) } \\
\text { All outcomes }\end{array}$ & Low risk & "identically-appearing capsules" \\
\hline
\end{tabular}

Sunshine $1983 b$

$\begin{array}{ll}\text { Methods } & \text { RCT, DB, single oral dose, parallel groups } \\ \text { Assessed at } 0,1 \mathrm{~h} \text { then hourly to } 6 \mathrm{~h}\end{array}$

Assessed at $0,1 \mathrm{~h}$ then hourly to $6 \mathrm{~h}$

\begin{tabular}{ll}
\hline Participants & $\begin{array}{l}\text { Episiotomy } \\
\mathrm{N}=168 \text { (152 for analysis) } \\
\text { Mean age } 24 \text { years }\end{array}$ \\
\hline Interventions & Aspirin $600 \mathrm{mg}, \mathrm{n}=29$ \\
& Flurbiprofen $25 \mathrm{mg}, \mathrm{n}=32$ \\
& Flurbiprofen $50 \mathrm{mg}, \mathrm{n}=29$
\end{tabular}


Sunshine 1983b (Continued)

Flurbiprofen $100 \mathrm{mg}, \mathrm{n}=31$

Placebo, $n=31$

Rescue medication allowed after $1 \mathrm{~h}$ (BOCF)

\begin{tabular}{|c|c|c|}
\hline Outcomes & \multicolumn{2}{|c|}{$\begin{array}{l}\text { PI: standard 4-point scale } \\
\text { PR: standard 5-point scale } \\
\text { Use of rescue medication } \\
\text { Withdrawals }\end{array}$} \\
\hline Notes & \multicolumn{2}{|c|}{ Oxford Quality Score: R=2, DB = 2, W = 1. Total $=5$} \\
\hline \multicolumn{3}{|l|}{ Risk of bias } \\
\hline Bias & Authors' judgement & Support for judgement \\
\hline $\begin{array}{l}\text { Random sequence genera- } \\
\text { tion (selection bias) }\end{array}$ & Low risk & Computer-generated \\
\hline $\begin{array}{l}\text { Allocation concealment } \\
\text { (selection bias) }\end{array}$ & Unclear risk & Not described \\
\hline $\begin{array}{l}\text { Blinding (performance } \\
\text { bias and detection bias) } \\
\text { All outcomes }\end{array}$ & Low risk & Tablets were "identical in appearance" \\
\hline
\end{tabular}

Sunshine $1983 \mathrm{C}$

Methods RCT, DB, single oral dose, parallel groups

Assessed at 0, 0.5, $1 \mathrm{~h}$ then hourly to $4 \mathrm{~h}$

Medication administered when pain severe

\begin{tabular}{ll}
\hline Participants & Episiotomy \\
& $\mathrm{N}=120$ \\
& Mean age 24 years \\
\hline Interventions & Aspirin $600 \mathrm{mg}, \mathrm{n}=30$ \\
& Ibuprofen $400 \mathrm{mg}, \mathrm{n}=30$ \\
& Zomepirac $100 \mathrm{mg}, \mathrm{n}=30$ \\
& Placebo, $\mathrm{n}=30$ \\
& Rescue medication allowed after 1 h (LOCF) \\
\hline Outcomes & Pl: standard 4-point scale \\
& PR: 5-point scale \\
& Global assessment: non-standard 7-point scale \\
& Use of rescue medication \\
& Adverse events \\
& Withdrawals
\end{tabular}

Notes Oxford Quality Score: $\mathrm{R}=1, \mathrm{DB}=2, \mathrm{~W}=1$. Total $=4$ 
Sunshine 1983C (Continued)

Risk of bias

\begin{tabular}{lll}
\hline Bias & Authors' judgement & Support for judgement \\
\hline $\begin{array}{l}\text { Random sequence genera- } \\
\text { tion (selection bias) }\end{array}$ & Unclear risk & Not described \\
\hline $\begin{array}{l}\text { Allocation concealment } \\
\text { (selection bias) }\end{array}$ & Unclear risk & Not described \\
\hline $\begin{array}{l}\text { Blinding (performance } \\
\text { bias and detection bias) } \\
\text { All outcomes }\end{array}$ & Low risk & "double-dummy technique" \\
\hline
\end{tabular}

Sunshine 1988

\begin{tabular}{ll}
\hline Methods & $\begin{array}{l}\text { RCT, DB, single oral dose, parallel groups } \\
\text { Assessed at } 0,1 \mathrm{~h} \text { then hourly to } 12 \mathrm{~h}\end{array}$ \\
\hline Participants & Study 2 \\
& Mixed general surgery (35\%) and gynaecological surgery $65 \%)$ \\
& $\mathrm{N}=61$ (60 for analysis) \\
& Age 31 to 33 years
\end{tabular}

\begin{tabular}{ll}
\hline Interventions & Aspirin $648 \mathrm{mg}, \mathrm{n}=15$ \\
& Piroxicam $20 \mathrm{mg}, \mathrm{n}=15$ \\
& Piroxicam $40 \mathrm{mg}, \mathrm{n}=15$ \\
& Placebo, $\mathrm{n}=15$
\end{tabular}

Rescue medication allowed (time not specified) (BOCF)

\begin{tabular}{ll}
\hline Outcomes & PR: standard 4-point scale \\
& Use of rescue medication \\
Adverse events \\
Withdrawals
\end{tabular}

Notes Oxford Quality Score: $\mathrm{R}=1, \mathrm{DB}=1, \mathrm{~W}=1$. Total $=3$

\section{Risk of bias}

\begin{tabular}{lll}
\hline Bias & Authors' judgement & Support for judgement \\
\hline $\begin{array}{l}\text { Random sequence genera- } \\
\text { tion (selection bias) }\end{array}$ & Unclear risk & Not described \\
\hline $\begin{array}{l}\text { Allocation concealment } \\
\text { (selection bias) }\end{array}$ & Unclear risk & Not described \\
\hline $\begin{array}{l}\text { Blinding (performance } \\
\text { bias and detection bias) }\end{array}$ & Unclear risk & Not described \\
\hline
\end{tabular}

Single dose oral aspirin for acute postoperative pain in adults (Review) 
Sunshine 1988 (Continued)

All outcomes

\section{Wang 1982}

\begin{tabular}{|c|c|}
\hline Methods & $\begin{array}{l}\mathrm{RCT}, \mathrm{DB} \text {, single oral dose, parallel groups } \\
\text { Assessed at } 0.5,1 \mathrm{~h} \text { then hourly to } 6 \mathrm{~h}\end{array}$ \\
\hline Participants & $\begin{array}{l}\text { Mixed general and orthopaedic surgery } \\
N=100 \\
\text { Age } 18 \text { to } 61 \text { years }\end{array}$ \\
\hline Interventions & $\begin{array}{l}\text { Aspirin } 650 \mathrm{mg}, \mathrm{n}=25 \\
\text { Bicifadine } 75 \mathrm{mg}, \mathrm{n}=25 \\
\text { Bicifadine } 150 \mathrm{mg}, \mathrm{n}=25 \\
\text { Placebo } \mathrm{n}=25 \\
\text { Rescue medication allowed (time not specified) (BOCF) }\end{array}$ \\
\hline Outcomes & $\begin{array}{l}\text { PI: standard 4-point scale } \\
\text { PR: standard 5-point scale }\end{array}$ \\
\hline Notes & Oxford Quality Score: $R=1, D B=2, W=0$. Total $=3$ \\
\hline Risk of bias & \\
\hline Bias & Authors' judgement Support for judgement \\
\hline $\begin{array}{l}\text { Random sequence genera- } \\
\text { tion (selection bias) }\end{array}$ & Not described \\
\hline $\begin{array}{l}\text { Allocation concealment } \\
\text { (selection bias) }\end{array}$ & "coded single-dose envelopes" \\
\hline $\begin{array}{l}\text { Blinding (performance } \\
\text { bias and detection bias) } \\
\text { All outcomes }\end{array}$ & "identically-appearing capsules" \\
\hline
\end{tabular}

Winter $1983 a$

\begin{tabular}{ll}
\hline Methods & RCT, DB, single oral dose, parallel groups \\
& Assessed at $0,1 \mathrm{~h}$ then hourly to $8 \mathrm{~h}$ \\
\hline Participants & $\begin{array}{l}\text { Dental surgery (complicated or multiple extractions or impactions) } \\
\mathrm{N}=105 \\
\text { Age } 18 \text { to } 65 \text { years }\end{array}$ \\
\hline Interventions & Aspirin $650 \mathrm{mg}, \mathrm{n}=37$ \\
& Oxaprozin $1200 \mathrm{mg}, \mathrm{n}=33$ \\
& Placebo, $\mathrm{n}=35$ \\
& Rescue medication (paracetamol plus codeine) allowed after $2 \mathrm{~h}$ (data handling not reported)
\end{tabular}


Winter 1983a (Continued)
Outcomes
PI: standard 4-point scale
PR: non-standard scale
Global assessment: non-standard 4-point scale
Use of rescue medication
Adverse events
Withdrawals

\begin{tabular}{lll}
\hline Notes & Oxford Quality Score: $\mathrm{R}=1, \mathrm{DB}=1, \mathrm{~W}=1$. Total $=3$ \\
\hline Risk of bias & & \\
\hline Bias & Authors' judgement & Support for judgement \\
\hline $\begin{array}{l}\text { Random sequence genera- } \\
\text { tion (selection bias) }\end{array}$ & Unclear risk & Not described \\
\hline $\begin{array}{l}\text { Allocation concealment } \\
\text { (selection bias) }\end{array}$ & Unclear risk & Not described \\
\hline $\begin{array}{l}\text { Blinding (performance } \\
\text { bias and detection bias) } \\
\begin{array}{l}\text { All outcomes } \\
\hline\end{array}\end{array}$ & Unclear risk & Not described \\
\hline
\end{tabular}

\section{Winter 1983b}

\begin{tabular}{|c|c|}
\hline Methods & $\begin{array}{l}\mathrm{RCT}, \mathrm{DB} \text {, single oral dose, parallel groups } \\
\text { Assessed at } 0.5,1 \mathrm{~h} \text { then hourly to } 4 \mathrm{~h}\end{array}$ \\
\hline Participants & $\begin{array}{l}\text { Dental surgery (complicated or multiple extractions or impactions) } \\
N=161 \\
\text { Mean age } 32 \text { years }\end{array}$ \\
\hline Interventions & $\begin{array}{l}\text { Aspirin } 650 \mathrm{mg}, \mathrm{n}=42 \\
\text { Phenyltoloxamine } 60 \mathrm{mg}+\text { paracetamol } 1000 \mathrm{mg}, \mathrm{n}=41 \\
\text { Placebo, } \mathrm{n}=44 \\
\text { Rescue medication allowed after } 2 \mathrm{~h} \text { (data handling not reported) }\end{array}$ \\
\hline Outcomes & $\begin{array}{l}\text { PI: standard 4-point scale } \\
\text { PR: standard 5-point scale } \\
\text { Global assessment: standard 5-point scale } \\
\text { Adverse events } \\
\text { Withdrawals }\end{array}$ \\
\hline Notes & Oxford Quality Score: $R=1, D B=2, W=1$. Total $=4$ \\
\hline Risk of bias & \\
\hline Bias & Authors' judgement Support for judgement \\
\hline $\begin{array}{l}\text { Random sequence genera- } \\
\text { tion (selection bias) }\end{array}$ & Not described \\
\hline
\end{tabular}


Winter 1983b (Continued)

\begin{tabular}{lll}
$\begin{array}{l}\text { Allocation concealment } \\
\text { (selection bias) }\end{array}$ & Unclear risk & Not described \\
\hline $\begin{array}{l}\text { Blinding (performance } \\
\text { bias and detection bias) } \\
\text { All outcomes }\end{array}$ & Low risk & "identically-appearing 2-capsule single doses"
\end{tabular}

$\mathrm{BOCF}=$ baseline observation carried forward; $\mathrm{DB}=$ double-blind; $\mathrm{h}=$ hour; $\mathrm{LOCF}=$ last observation carried forward; $\mathrm{N}=$ number of participants in study; $n=$ number of participants in treatment arm; $\mathrm{PI}=$ pain intensity; $\mathrm{PR}=$ pain relief; $\mathrm{RCT}=$ randomised controlled trial; VAS = visual analogue scale; $W=$ withdrawals

\section{Characteristics of excluded studies [ordered by study ID]}

\begin{tabular}{|c|c|}
\hline Study & Reason for exclusion \\
\hline Ahlstrom 1968 & No extractable data \\
\hline Ahlstrom 1974 & No extractable data \\
\hline Antonsson 1985 & No placebo \\
\hline Aromaa 1978 & No placebo \\
\hline Barrenechea 1981 & Not randomised \\
\hline Bella 1987 & No placebo \\
\hline Bhounsule 1990 & Did not state baseline pain \\
\hline Bloomfield 1974 & No extractable data \\
\hline Bloomfield 1976 & Baseline pain intensity not given so no extractable data \\
\hline Boerlin 1986 & Not randomised (MEDLINE indexed as RCT) \\
\hline Burguet 1989 & No placebo \\
\hline Campos 1980 & Included patients with somatic pain \\
\hline Capuano 1990 & No placebo \\
\hline Carstens 1987 & $\begin{array}{l}\text { Unable to obtain the paper locally or through the British Library. Not indexed in MEDLINE as ran- } \\
\text { domised controlled trial }\end{array}$ \\
\hline Cooper 1976 & Only 3 hours observation time \\
\hline Cooper 1979b & $\begin{array}{l}\text { Inappropriate formulation ?? Probably not randomised (not indexed RCT) and probably no } \\
\text { placebo }\end{array}$ \\
\hline Cooper 1980a & Inappropriate study design ?? Probably not randomised (not indexed RCT) \\
\hline Cooper 1980b & Duplicate publication of Cooper 1980a (excluded) \\
\hline Cordero 1985 & Unable to obtain the paper locally or through the British Library \\
\hline
\end{tabular}




\begin{tabular}{|c|c|}
\hline Study & Reason for exclusion \\
\hline Dahl 1985 & No placebo \\
\hline Desjardins 1983 & Inappropriate study design ?? \\
\hline Di Blasi 1980a & No placebo, includes children (<12 years) \\
\hline Di Blasi 1980b & No placebo, includes children ( $<12$ years) \\
\hline Feldmeier 1982 & Non-standard pain measures \\
\hline Fink 1978 & Included patients with 'slight' baseline pain \\
\hline Fleiss 1979 & No extractable data \\
\hline Friedrich 1983 & Non-standard pain measures \\
\hline Fuccella 1977 & Inappropriate study design ?? \\
\hline Gallardo 1982 & Observation period only 3 hours \\
\hline Gallardo 1984 & Observation period only 3 hours \\
\hline Gallardo 1990 & Not randomised \\
\hline Gallardo 1992 & Observation period only 3 hours \\
\hline Gammelgaard 1981 & No extractable data \\
\hline Giglio 1984 & Medication administered preoperatively - inadequate baseline pain \\
\hline Giles 1986 & Inappropriate study design - data from patients remedicating were not handled correctly \\
\hline Green 1978 & Not randomised \\
\hline Grippaudo 1981 & No placebo \\
\hline Happonen 1987 & No placebo \\
\hline Heimdahl 1979 & Inadequate baseline pain \\
\hline Henrikson 1979 & Intervention given immediately after surgery without regard to baseline pain \\
\hline Hepso 1976 & Not double-blind (title says double-blind) \\
\hline Herrmann 1980c & Includes participants with pain due to trauma \\
\hline Herrmann 1980d & Includes participants with pain due to trauma \\
\hline Hill 1969 & Inadequate baseline pain \\
\hline Hutton 1983 & No extractable data \\
\hline Ihalainen 1980 & No placebo \\
\hline Irwin 1984 & No placebo \\
\hline
\end{tabular}




\begin{tabular}{|c|c|}
\hline Study & Reason for exclusion \\
\hline Izquierdo 1995 & No placebo, intravenous administration \\
\hline Jain 1978a & Study 1: combined data for episiotomy and uterine cramps. Study 2: non-standard pain scales \\
\hline Jain 1978b & No usable data \\
\hline Joubert 1982 & Not randomised \\
\hline Kamiyama 1980 & No placebo \\
\hline Kantor 1965 & Includes participants with pain due to fracture \\
\hline Kristensen 1986 & No placebo \\
\hline Kristensen 1988 & No placebo \\
\hline Lamphier 1974 & Multiple dose study - 1 tablet every 3 hours \\
\hline Lobo 1983 & Observation period only 3 hours long \\
\hline Maeglin 1979 & Observation period only 3 hours long \\
\hline Mahler 1976 & Not randomised, no placebo \\
\hline Mandujano & Unable to obtain the paper locally or through the British Library \\
\hline Mehta 1986 & No extractable data \\
\hline Mitchell 1985 & Baseline pain not of moderate to severe intensity \\
\hline Mukherjee 1980 & No extractable data \\
\hline Okun 1979 & Includes participants with musculoskeletal pain and fractures \\
\hline Okun 1982 & Non-standard pain scales therefore no extractable data \\
\hline Or 1985 & Unable to obtain the paper locally or through the British Library. Probably no placebo \\
\hline Ormiston 1981 & No placebo \\
\hline Parker 1986 & Baseline pain and age not reported. Dose of aspirin unclear \\
\hline Parkhouse $1967 a$ & Not double-blind \\
\hline Parkhouse 1967b & Inadequate baseline pain \\
\hline Parkhouse 1968 & Baseline pain not reported \\
\hline Perotti 1984 & No placebo \\
\hline Reines 1986 & Inadequate baseline pain \\
\hline Rowe 1981 & Inadequate baseline pain \\
\hline Rye 1978 & Duplicate publication; data already included in studies published by Cooper \\
\hline
\end{tabular}




\begin{tabular}{|c|c|}
\hline Study & Reason for exclusion \\
\hline Sechzer 1977 & Included patients with postpartum uterine cramps \\
\hline Seymour 1982 & Inadequate baseline pain \\
\hline Seymour 1983a & Not randomised \\
\hline Seymour $1983 \mathrm{~b}$ & Inadequate baseline pain \\
\hline Seymour 1984 & Inadequate baseline pain \\
\hline Sindet 1986 & No placebo \\
\hline Skjelbred 1977 & No placebo \\
\hline Skjelbred 1984 & Inadequate baseline pain \\
\hline Slatis 1980 & No placebo \\
\hline Spivach 1984 & No placebo \\
\hline Sunshine 1975 & Included patients with somatic pain \\
\hline Sunshine 1978a & Included patients with somatic pain \\
\hline Sunshine $1978 \mathrm{~b}$ & Included patients with somatic pain \\
\hline Sunshine 1986 & Included patients with postpartum uterine cramps \\
\hline Sveen 1975 & Inadequate baseline pain \\
\hline Szmyd 1959 & Inadequate baseline pain \\
\hline Todorovic 1982 & No placebo \\
\hline Trop 1983 & Non-standard pain scales therefore no extractable data \\
\hline Vaidya 1974 & Non-standard pain scales therefore no extractable data \\
\hline Versichelen 1982 & No extractable data \\
\hline Von Graffenried 1980 & Observation period only 3 hours long \\
\hline Walker 1960 & Not randomised \\
\hline Wang 1979 & Includes participants with fracture. No separate results for postoperative pain \\
\hline Wilkinson 1960 & No placebo \\
\hline Winter 1978 & Observation period only 3 hours long \\
\hline Wojcicki 1977 & Observation period only 1 hour long \\
\hline Zederfeldt 1977 & Inadequate baseline pain \\
\hline
\end{tabular}

$\mathrm{RCT}=$ randomised controlled trial 
DATA AND ANALYSES

Comparison 1. Aspirin $500 \mathrm{mg}$ versus placebo

\begin{tabular}{lllll}
\hline Outcome or subgroup title & No. of studies & $\begin{array}{l}\text { No. of partici- } \\
\text { pants }\end{array}$ & Statistical method & Effect size \\
\hline $\begin{array}{l}\text { 1 Participants with at least } 50 \% \text { pain re- } \\
\text { lief }\end{array}$ & 2 & 213 & $\begin{array}{l}\text { Risk Ratio (M-H, Fixed, 95\% } \\
\text { Cl) }\end{array}$ & $1.28[0.82,2.00]$ \\
\hline
\end{tabular}

Analysis 1.1. Comparison 1 Aspirin $500 \mathrm{mg}$ versus placebo, Outcome 1 Participants with at least $50 \%$ pain relief.

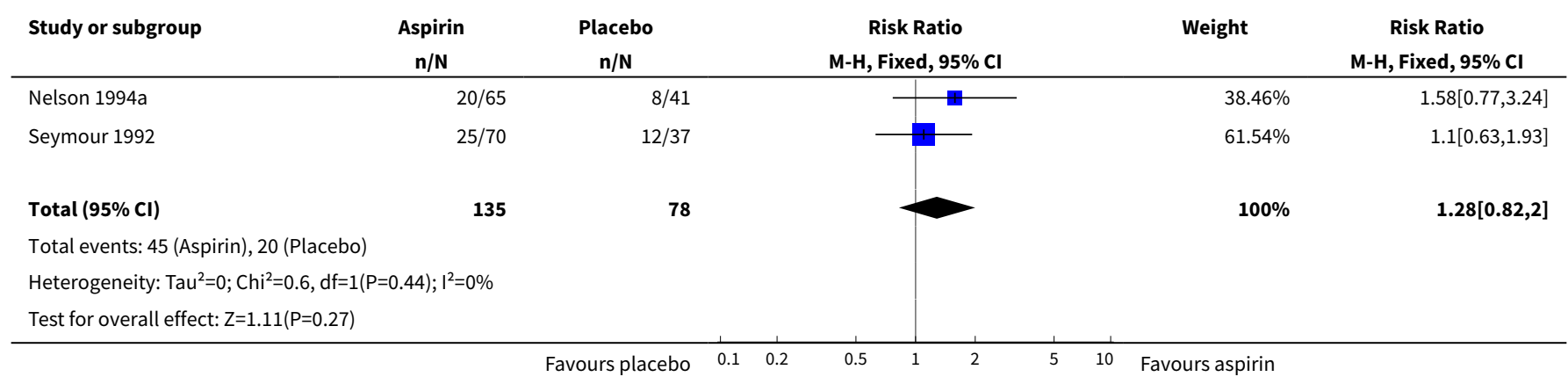

\section{Comparison 2. Aspirin 600 or $650 \mathrm{mg}$ versus placebo}

\begin{tabular}{|c|c|c|c|c|}
\hline Outcome or subgroup title & No. of studies & $\begin{array}{l}\text { No. of partici- } \\
\text { pants }\end{array}$ & Statistical method & Effect size \\
\hline $\begin{array}{l}1 \text { Participants with at least } 50 \% \text { pain } \\
\text { relief }\end{array}$ & 59 & 4644 & $\begin{array}{l}\text { Risk Ratio (M-H, Fixed, 95\% } \\
\text { Cl) }\end{array}$ & $2.46[2.22,2.72]$ \\
\hline 1.1 Dental surgery & 43 & 3433 & $\begin{array}{l}\text { Risk Ratio (M-H, Fixed, 95\% } \\
\text { Cl) }\end{array}$ & $2.53[2.23,2.88]$ \\
\hline 1.2 Non-dental surgery & 17 & 1211 & $\begin{array}{l}\text { Risk Ratio (M-H, Fixed, 95\% } \\
\text { Cl) }\end{array}$ & $2.31[1.93,2.75]$ \\
\hline $\begin{array}{l}2 \text { Participants using rescue medica- } \\
\text { tion at } 4 \text { to } 5 \mathrm{~h}\end{array}$ & 11 & 982 & $\begin{array}{l}\text { Risk Ratio (M-H, Fixed, 95\% } \\
\text { Cl) }\end{array}$ & $0.58[0.50,0.67]$ \\
\hline $\begin{array}{l}3 \text { Participants using rescue medica- } \\
\text { tion at } 6 \mathrm{~h}\end{array}$ & 20 & 1923 & $\begin{array}{l}\text { Risk Ratio (M-H, Fixed, 95\% } \\
\mathrm{Cl})\end{array}$ & $0.77[0.73,0.82]$ \\
\hline $\begin{array}{l}4 \text { Participants using rescue medica- } \\
\text { tion at } 12 \mathrm{~h}\end{array}$ & 4 & 291 & $\begin{array}{l}\text { Risk Ratio (M-H, Fixed, 95\% } \\
\mathrm{Cl})\end{array}$ & $0.95[0.86,1.05]$ \\
\hline 5 Any adverse event & 46 & 3633 & $\begin{array}{l}\text { Risk Ratio (M-H, Fixed, 95\% } \\
\text { Cl) }\end{array}$ & $1.20[1.00,1.44]$ \\
\hline
\end{tabular}


Analysis 2.1. Comparison 2 Aspirin 600 or $650 \mathrm{mg}$ versus placebo, Outcome 1 Participants with at least $50 \%$ pain relief.

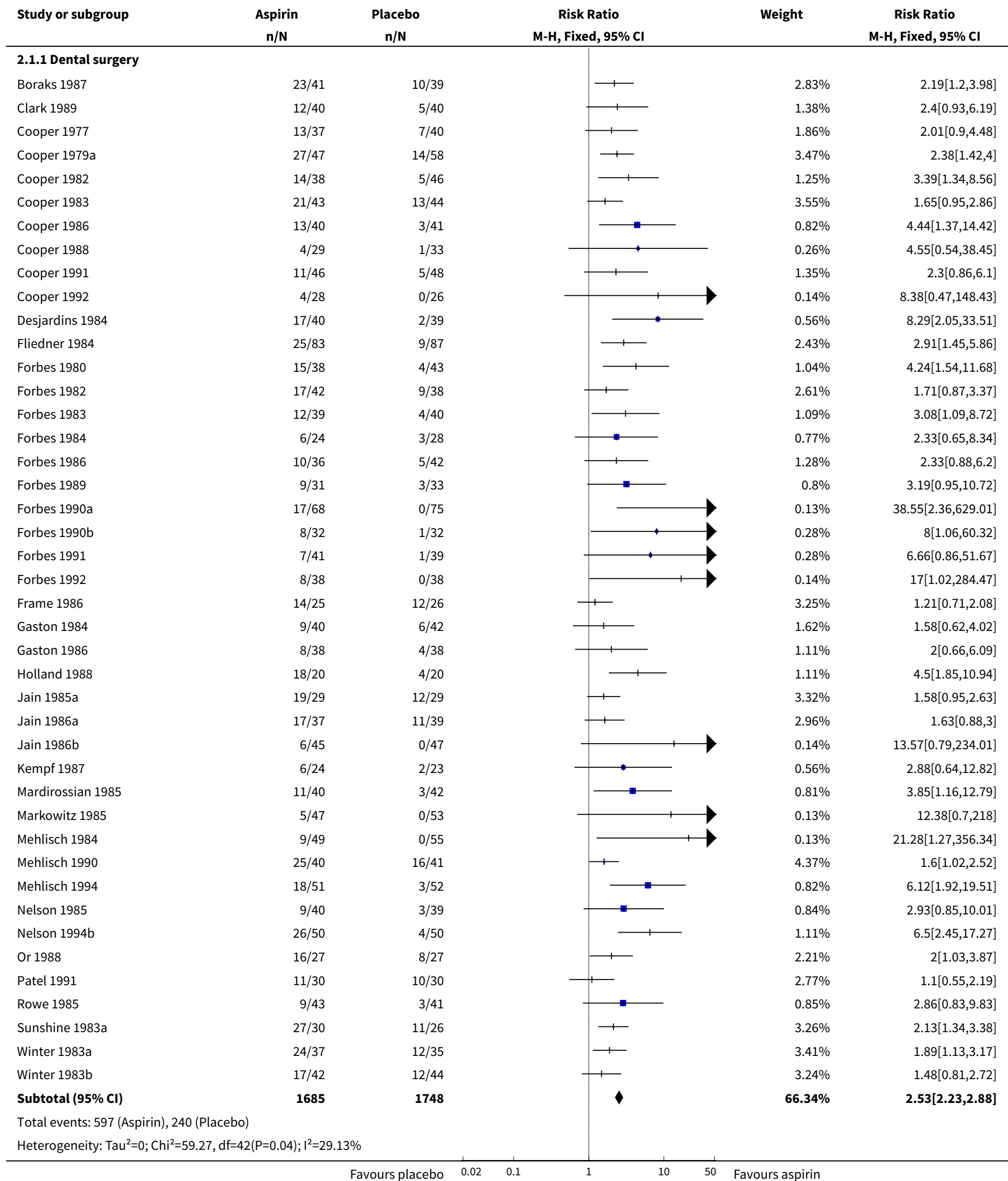




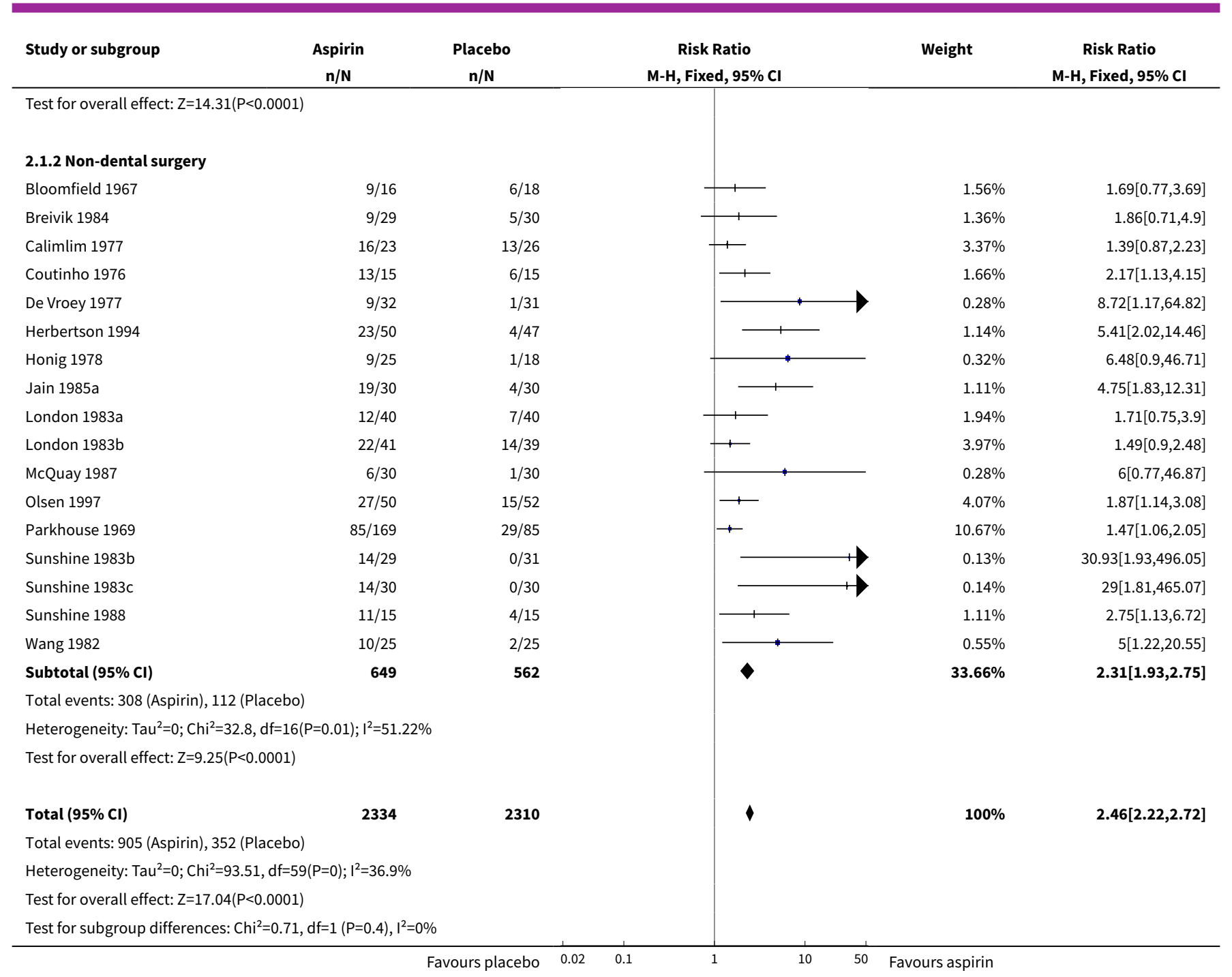

Analysis 2.2. Comparison 2 Aspirin 600 or $650 \mathrm{mg}$ versus placebo, Outcome 2 Participants using rescue medication at 4 to $5 \mathrm{~h}$.

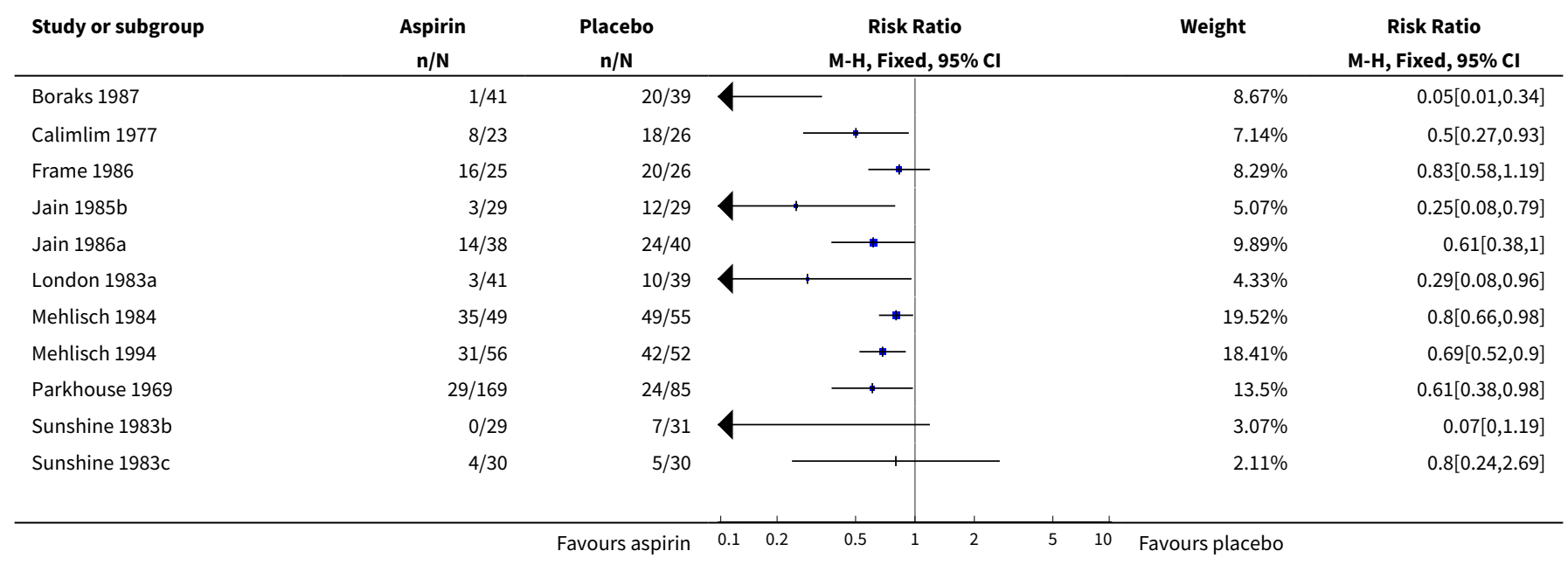




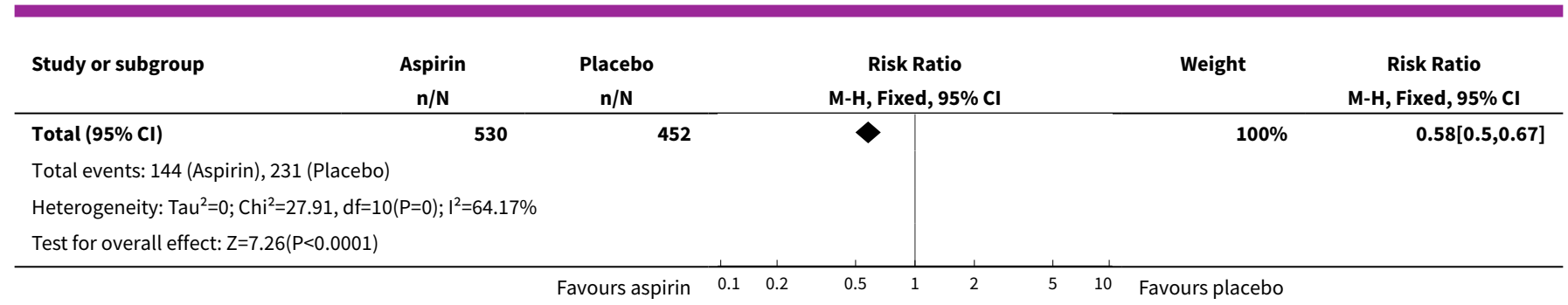

Analysis 2.3. Comparison 2 Aspirin 600 or $650 \mathrm{mg}$ versus placebo, Outcome 3 Participants using rescue medication at $6 \mathrm{~h}$.

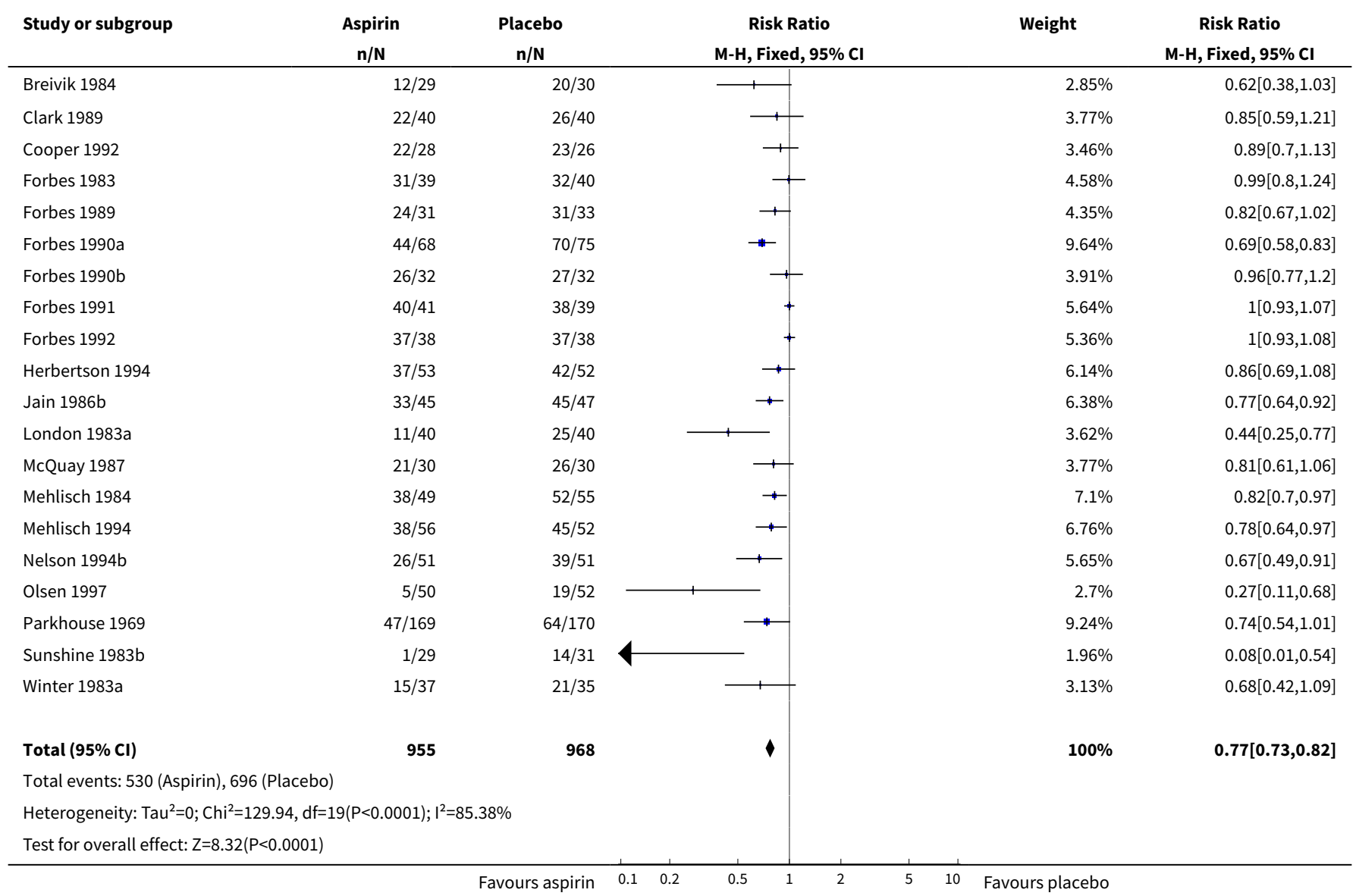

Analysis 2.4. Comparison 2 Aspirin 600 or $650 \mathrm{mg}$ versus placebo, Outcome 4 Participants using rescue medication at $12 \mathrm{~h}$.

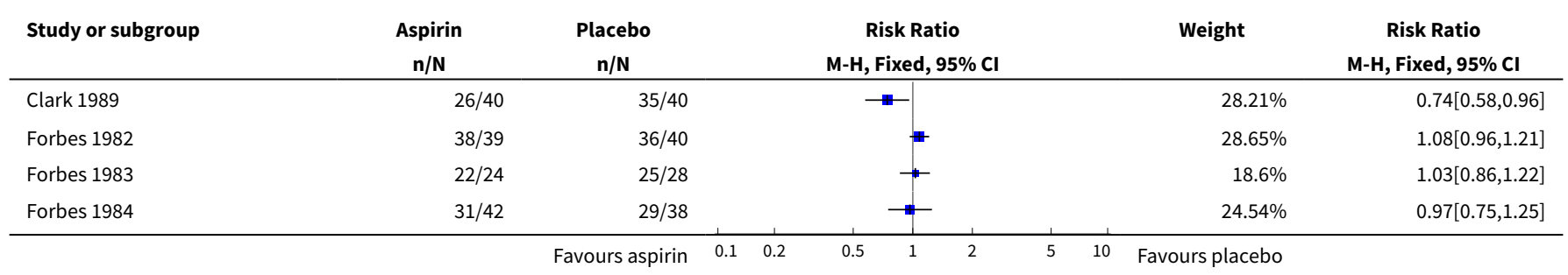




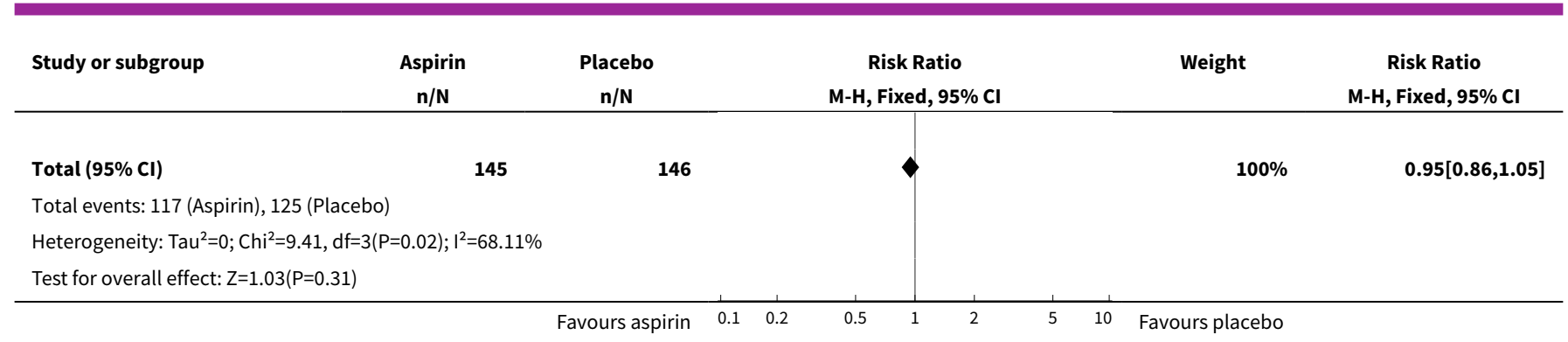

Analysis 2.5. Comparison 2 Aspirin 600 or $650 \mathrm{mg}$ versus placebo, Outcome 5 Any adverse event.

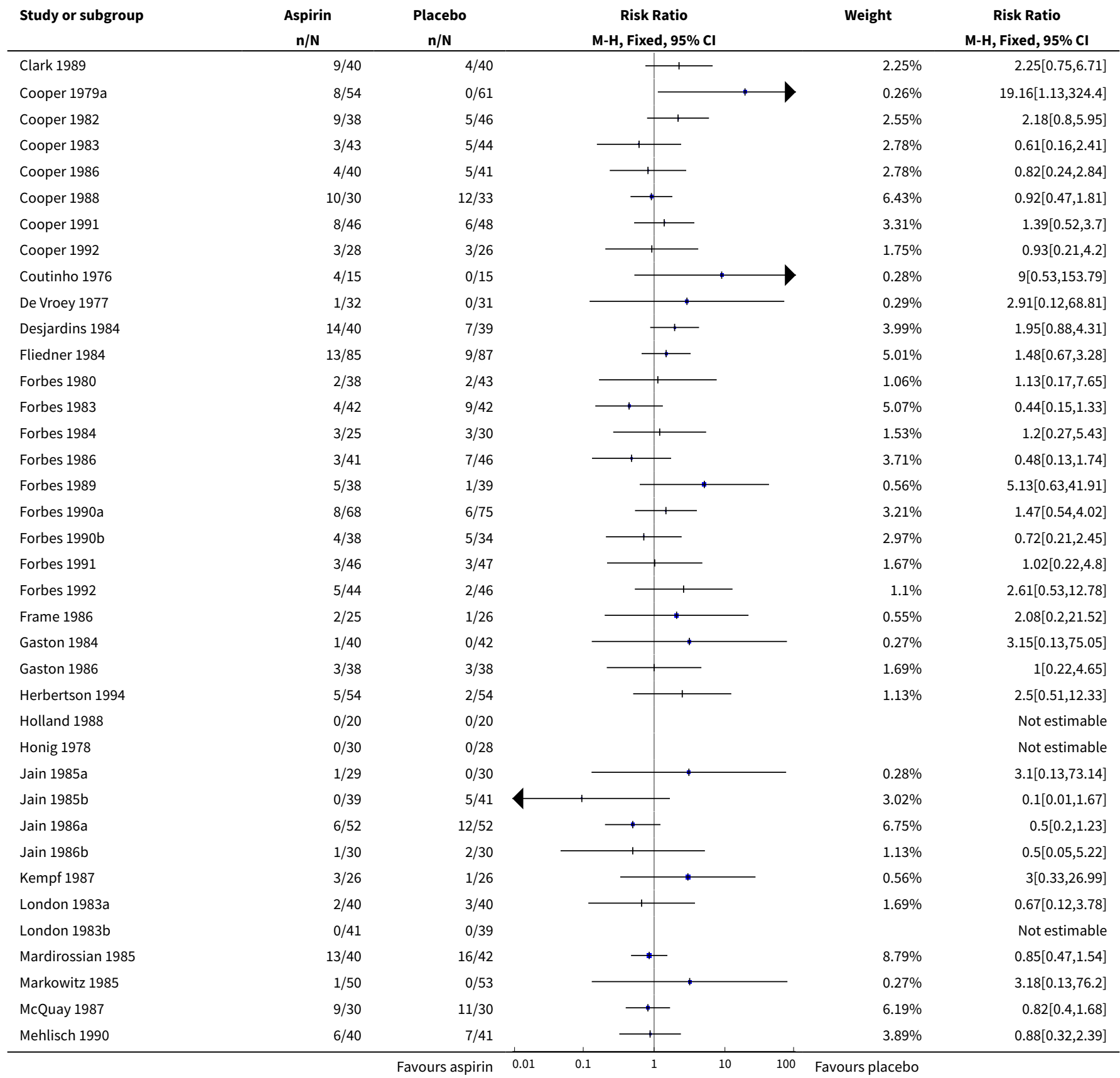




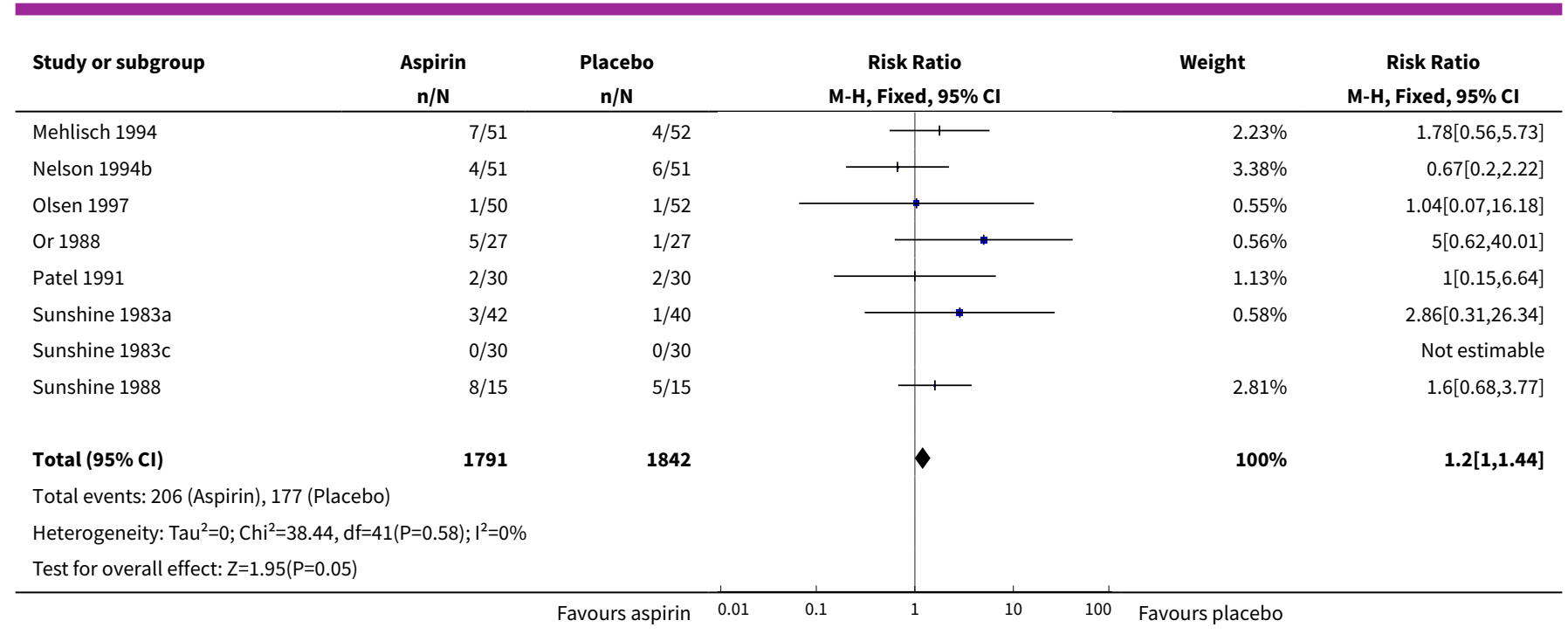

\section{Comparison 3. Aspirin 900 or $1000 \mathrm{mg}$ versus placebo}

\begin{tabular}{lllll}
\hline Outcome or subgroup title & No. of studies & $\begin{array}{l}\text { No. of partici- } \\
\text { pants }\end{array}$ & Statistical method & Effect size \\
\hline $\begin{array}{l}\text { 1 Participants with at least 50\% pain } \\
\text { relief }\end{array}$ & 6 & 618 & $\begin{array}{l}\text { Risk Ratio (M-H, Fixed, 95\% } \\
\text { Cl) }\end{array}$ & $2.70[2.00,3.64]$ \\
\hline $\begin{array}{l}\text { 2 Participants using rescue medication } \\
\text { at 4 to 5 h }\end{array}$ & 5 & 501 & $\begin{array}{l}\text { Risk Ratio (M-H, Fixed, 95\% } \\
\text { Cl) }\end{array}$ & $0.64[0.56,0.74]$ \\
\hline $\begin{array}{l}\text { 3 Participants using rescue medication } \\
\text { at 6 h }\end{array}$ & 2 & 233 & $\begin{array}{l}\text { Risk Ratio (M-H, Fixed, 95\% } \\
\text { Cl) }\end{array}$ & $0.82[0.71,0.95]$ \\
\hline \begin{tabular}{l} 
4 Any adverse event \\
\hline
\end{tabular} & 4 & 404 & $\begin{array}{l}\text { Risk Ratio (M-H, Fixed, 95\% } \\
\text { Cl) }\end{array}$ & $1.55[1.05,2.30]$ \\
\hline
\end{tabular}

Analysis 3.1. Comparison 3 Aspirin 900 or 1000 mg versus placebo, Outcome 1 Participants with at least 50\% pain relief.

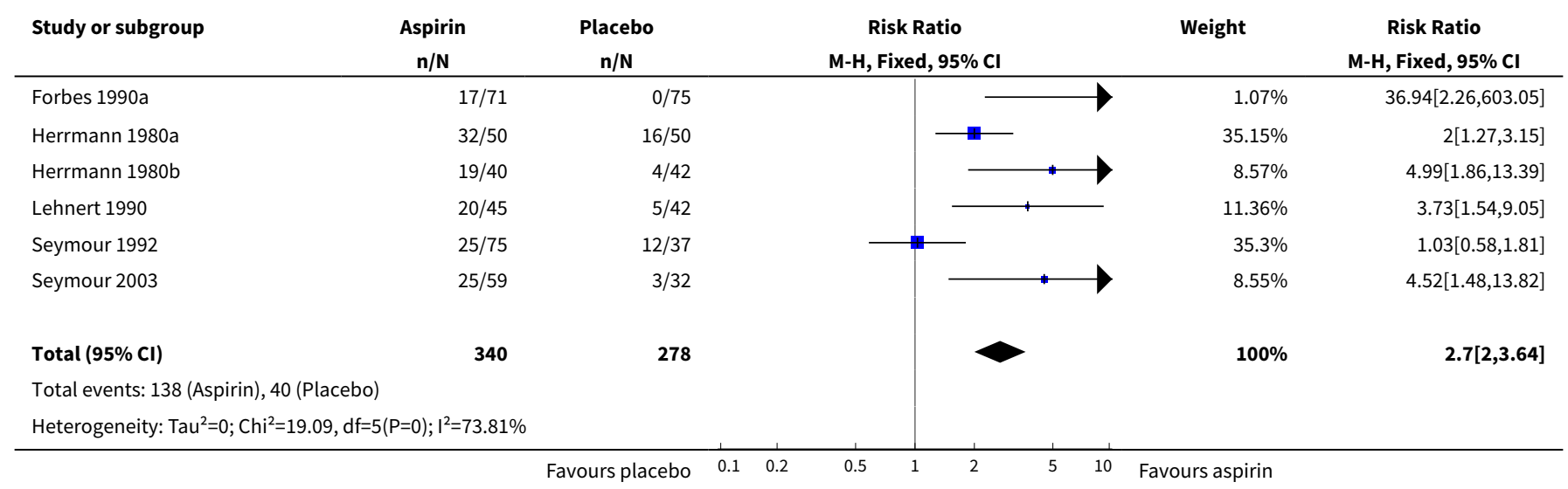




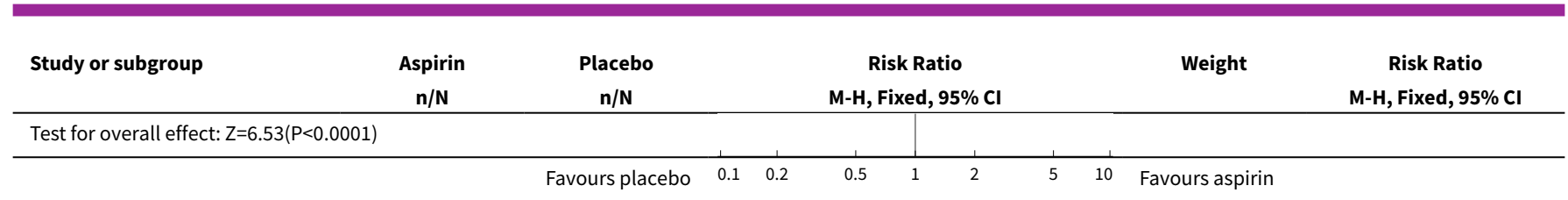

Analysis 3.2. Comparison 3 Aspirin 900 or $1000 \mathrm{mg}$ versus placebo, Outcome 2 Participants using rescue medication at 4 to $5 \mathrm{~h}$.

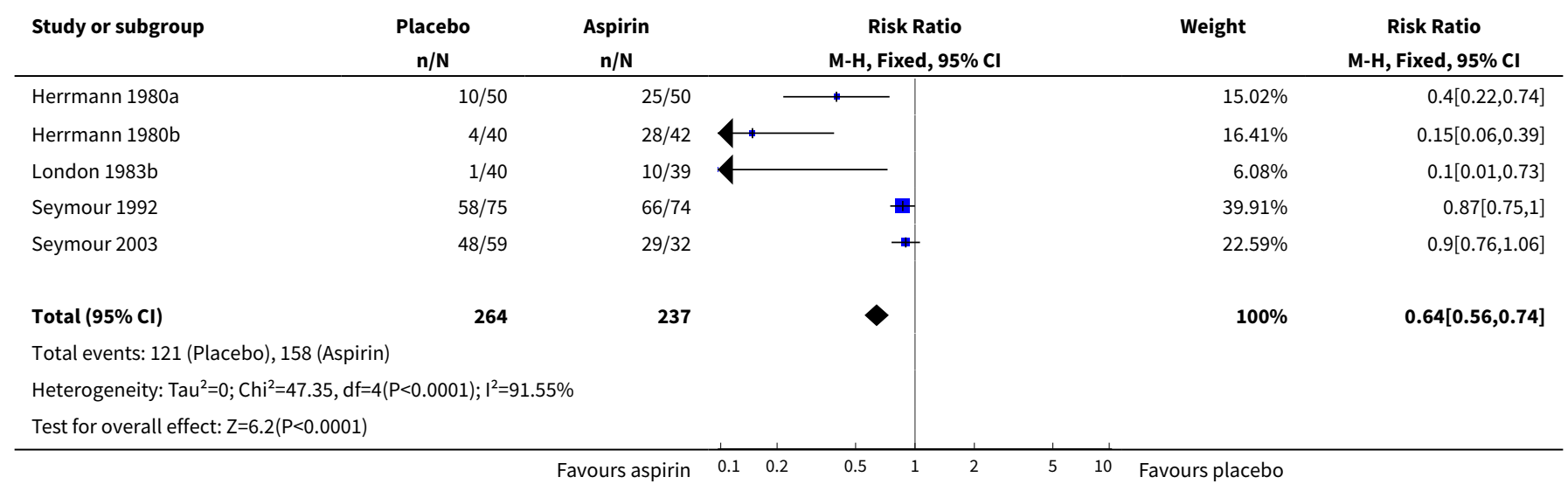

Analysis 3.3. Comparison 3 Aspirin 900 or $1000 \mathrm{mg}$ versus placebo, Outcome 3 Participants using rescue medication at $6 \mathrm{~h}$.

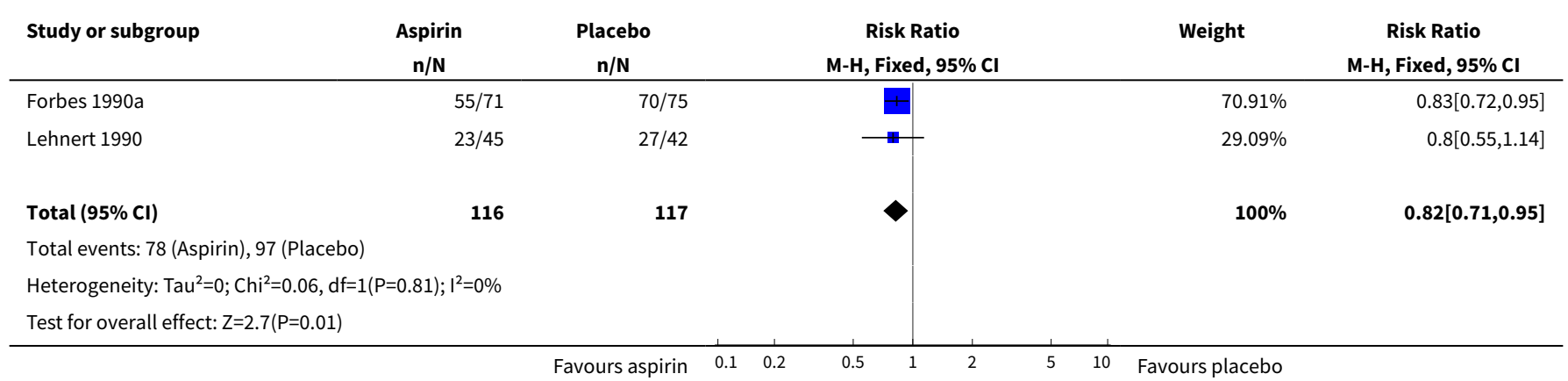

Analysis 3.4. Comparison 3 Aspirin 900 or 1000 mg versus placebo, Outcome 4 Any adverse event.

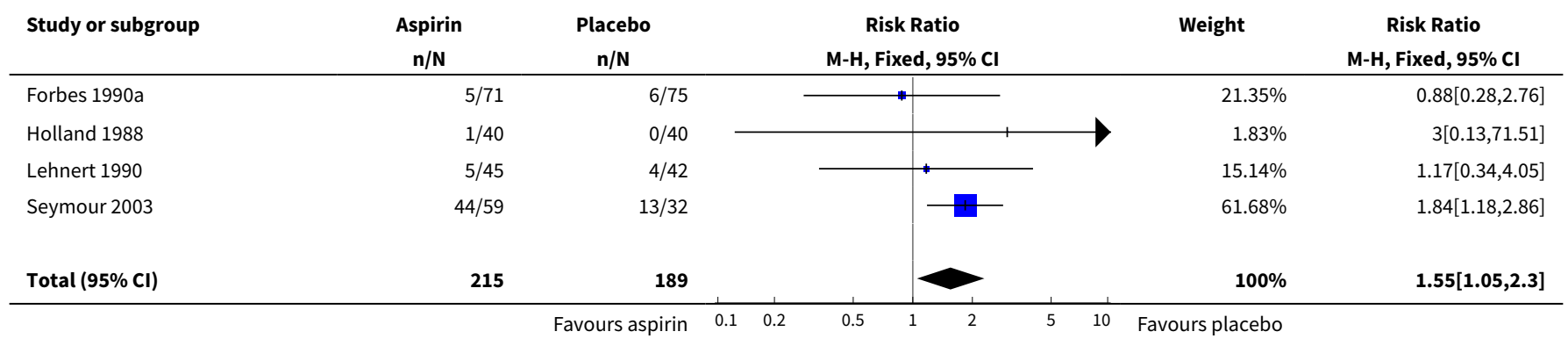




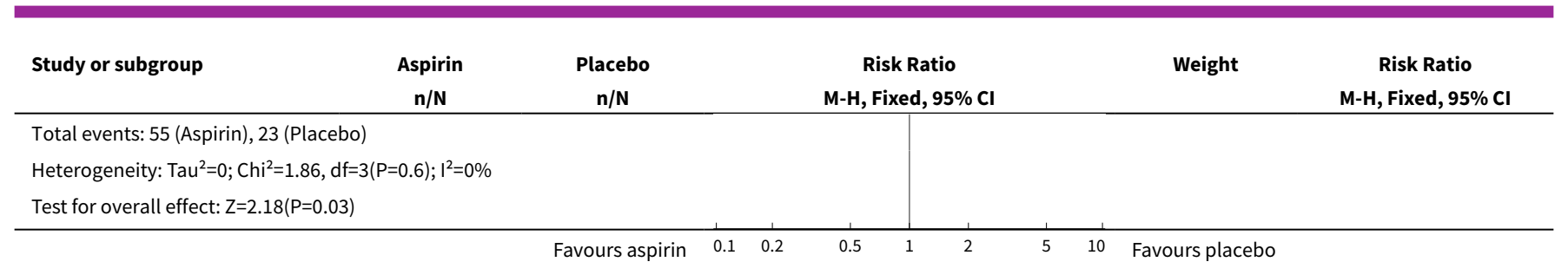

\section{Comparison 4. Aspirin $1200 \mathrm{mg}$ versus placebo}

\begin{tabular}{lllll}
\hline Outcome or subgroup title & No. of studies & $\begin{array}{l}\text { No. of partici- } \\
\text { pants }\end{array}$ & Statistical method & Effect size \\
\hline $\begin{array}{l}\text { 1 Participants with at least 50\% pain re- } \\
\text { lief }\end{array}$ & 3 & 249 & $\begin{array}{l}\text { Risk Ratio (M-H, Fixed, 95\% } \\
\text { Cl) }\end{array}$ & $2.86[1.95,4.20]$ \\
\hline
\end{tabular}

Analysis 4.1. Comparison 4 Aspirin $1200 \mathrm{mg}$ versus placebo, Outcome 1 Participants with at least $50 \%$ pain relief.

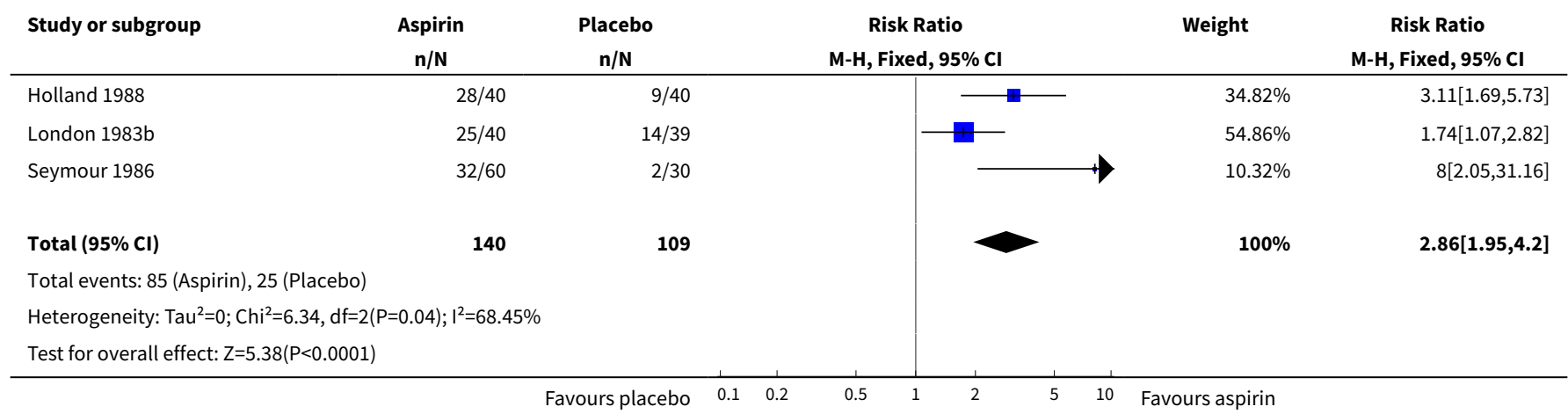

\section{APPENDICES}

\section{Appendix 1. Search strategy}

1. Aspirin/

2. (aspirin OR acetylsalicylic acid).ti,ab,kw.

3. $\mathrm{OR} / 1-2$

4. Postoperative pain/

5. ((postoperative adj4 pain\$) or (post-operative adj4 pain\$) or post-operative-pain $\$$ or (post\$ NEAR pain\$) or (postoperative adj4 analgesi \$) or (post-operative adj4 analgesi\$) or ("post-operative analgesi\$")).ti,ab,kw.

6. ((post-surgical adj4 pain\$) or ("post surgical" adj4 pain\$) or (post-surgery adj4 pain\$)).ti,ab,kw.

7. (("pain-relief after surg\$") or ("pain following surg\$") or ("pain control after")).ti,ab,kw.

8. (("post surg\$" or post-surg\$) AND (pain\$ or discomfort)).ti,ab,kw.

9. ((pain\$ adj4 "after surg\$") or (pain\$ adj4 "after operat\$") or (pain\$ adj4 "follow\$ operat\$") or (pain\$ adj4 "follow\$ surg\$")).ti,ab,kw.

10.((analgesi\$ adj4 "after surg\$") or (analgesi\$ adj4 "after operat\$") or (analgesi\$ adj4 "follow\$ operat\$") or (analgesi\$ adj4 "follow\$ surg \$")).ti,ab,kw.

11.OR/4-10

12.clinical trials.sh.

13.controlled clinical trials.sh.

Single dose oral aspirin for acute postoperative pain in adults (Review) 
14.randomized controlled trial.sh.

15.double-blind procedure.sh.

16. (clin\$ adj25 trial\$).ab.

17. ((doubl\$ or trebl\$ or tripl\$) adj25 (blind\$ or mask\$)).ab.

18. placebo\$.ab.

19.random\$.ab.

20.0R/12-19

21.3 AND 11 AND 20

\section{Appendix 2. Search strategy for EMBASE (via OVID)}

1. Acetylsalicylic acid/

2. (aspirin OR acetylsalicylic acid).ti,ab,kw.

3. $\mathrm{OR} / 1-2$

4. Postoperative pain/

5. ((postoperative adj4 pain\$) or (post-operative adj4 pain\$) or post-operative-pain\$ or (post\$ NEAR pain\$) or (postoperative adj4 analgesi \$) or (post-operative adj4 analgesi\$) or ("post-operative analgesi\$")).ti,ab,kw.

6. ((post-surgical adj4 pain\$) or ("post surgical" adj4 pain\$) or (post-surgery adj4 pain\$)).ti,ab,kw.

7. (("pain-relief after surg\$") or ("pain following surg\$") or ("pain control after")).ti,ab,kw.

8. (("post surg\$" or post-surg\$) AND (pain\$ or discomfort)).ti,ab,kw.

9. ((pain\$ adj4 "after surg\$") or (pain\$ adj4 "after operat\$") or (pain\$ adj4 "follow\$ operat\$") or (pain\$ adj4 "follow\$ surg\$")).ti,ab,kw.

10.((analgesi\$ adj4 "after surg\$") or (analgesi\$ adj4 "after operat\$") or (analgesi\$ adj4 "follow\$ operat\$") or (analgesi\$ adj4 "follow\$ surg $\$ ")) . t i, a b, k w$.

11.OR/4-10

12.clinical trials.sh.

13.controlled clinical trials.sh.

14.randomized controlled trial.sh.

15.double-blind procedure.sh.

16. (clin\$ adj25 trial\$).ab.

17. ((doubl\$ or trebl\$ or tripl\$) adj25 (blind\$ or mask\$)).ab.

18. placebo\$.ab.

19.random\$.ab.

20.0R/12-19

21.3 AND 11 AND 20

Appendix 3. Search strategy for CENTRAL

1. MESH descriptor Aspirin

2. (aspirin $O R$ acetylsalicylic acid).ti,ab,kw.

3. $\mathrm{OR} / 1-2$

4. MESH descriptor Pain, Postoperative

5. ((postoperative adj4 pain\$) or (post-operative adj4 pain\$) or post-operative-pain\$ or (post\$ NEAR pain\$) or (postoperative adj4 analgesi \$) or (post-operative adj4 analgesi\$) or ("post-operative analgesi\$")):ti,ab,kw.

6. ((post-surgical adj4 pain\$) or ("post surgical" adj4 pain\$) or (post-surgery adj4 pain\$)):ti,ab,kw.

7. (("pain-relief after surg\$") or ("pain following surg\$") or ("pain control after")):ti,ab,kw.

8. (("post surg\$" or post-surg\$) AND (pain\$ or discomfort)):ti,ab,kw.

9. ((pain\$ adj4 "after surg\$") or (pain\$ adj4 "after operat\$") or (pain\$ adj4 "follow\$ operat\$") or (pain\$ adj4 "follow\$ surg\$")):ti,ab,kw.

10.((analgesi\$ adj4 "after surg\$") or (analgesi\$ adj4 "after operat\$") or (analgesi\$ adj4 "follow\$ operat\$") or (analgesi\$ adj4 "follow\$ surg \$")):ti,ab,kw.

11.OR/4-10

12. Clinical trials:pt.

13. Controlled Clinical Trial:pt.

14. Randomized Controlled Trial.pt.

15.MESH descriptor Double-Blind Method

16. (clin\$ adj25 trial\$):ti,ab,kw. 
17.((doubl\$ or trebl\$ or tripl\$) adj25 (blind\$ or mask\$)):ti,ab,kw.

18. placebo\$:ti,ab,kw.

19.random\$:ti,ab,kw.

20.0R/12-19

21.3 AND 11 AND 20

\section{Appendix 4. Glossary}

Categorical rating scale: the commonest is the five category scale (none, slight, moderate, good or lots, and complete). For analysis numbers are given to the verbal categories (for pain intensity, none $=0$, mild $=1$, moderate $=2$, and severe $=3$, and for relief none $=0$, slight $=1$, moderate $=2$, good or lots $=3$, and complete $=4$ ). Data from different subjects are then combined to produce means (rarely medians) and measures of dispersion (usually standard errors of means). The validity of converting categories into numerical scores was checked by comparison with concurrent visual analogue scale measurements. Good correlation was found, especially between pain relief scales using cross-modality matching techniques. Results are usually reported as continuous data, mean or median pain relief or intensity. Few studies present results as discrete data, giving the number of participants who report a certain level of pain intensity or relief at any given assessment point. The main advantages of the categorical scales are that they are quick and simple. The small number of descriptors may force the scorer to choose a particular category when none describes the pain satisfactorily.

VAS: visual analogue scale: lines with left end labelled "no relief of pain" and right end labelled "complete relief of pain", seem to overcome this limitation. Patients mark the line at the point which corresponds to their pain. The scores are obtained by measuring the distance between the no relief end and the patient's mark, usually in millimetres. The main advantages of VAS are that they are simple and quick to score, avoid imprecise descriptive terms and provide many points from which to choose. More concentration and co-ordination are needed, which can be difficult postoperatively or with neurological disorders.

TOTPAR: total pain relief (TOTPAR) is calculated as the sum of pain relief scores over a period of time. If a patient had complete pain relief immediately after taking an analgesic, and maintained that level of pain relief for six hours, they would have a six-hour TOTPAR of the maximum of 24. Differences between pain relief values at the start and end of a measurement period are dealt with by the composite trapezoidal rule. This is a simple method that approximately calculates the definite integral of the area under the pain relief curve by calculating the sum of the areas of several trapezoids that together closely approximate to the area under the curve.

SPID: summed pain intensity difference (SPID) is calculated as the sum of the differences between the pain scores over a period of time. Differences between pain intensity values at the start and end of a measurement period are dealt with by the trapezoidal rule.

VAS TOTPAR and VAS SPID are visual analogue versions of TOTPAR and SPID.

See 'Measuring pain' in Bandolier's Little Book of Pain, Oxford University Press, Oxford. 2003; pp 7-13 (Moore 2003).

Appendix 5. Summary of outcomes: analgesia and rescue medication

\begin{tabular}{|c|c|c|c|c|c|}
\hline & & Analgesia & & Rescue medic & \\
\hline Study ID & Treatment & PI or PR & $\begin{array}{l}\text { Number with } \\
50 \% \text { PR }\end{array}$ & $\begin{array}{l}\text { Median time } \\
\text { to use (h) }\end{array}$ & $\%$ using \\
\hline $\begin{array}{l}\text { Bloomfield } \\
1967\end{array}$ & $\begin{array}{l}\text { (1) aspirin } 600 \mathrm{mg}, \mathrm{n}=16 \\
\text { (2) placebo, } \mathrm{n}=18 \\
\text { Also } 3 \text { doses of chlorphenesin }(\mathrm{n}=50)\end{array}$ & $\begin{array}{l}\text { SPID } 6 \\
\text { (1) } 6.71 \\
\text { (2) } 4.29\end{array}$ & $\begin{array}{l}\text { (1) } 9 / 16 \\
\text { (2) } 6 / 18\end{array}$ & No data & No data \\
\hline Boraks 1987 & $\begin{array}{l}\text { (1) aspirin } 650 \mathrm{mg}, \mathrm{n}=41 \\
\text { (2) placebo, } \mathrm{n}=39 \\
\text { Also flurbiprofen and dipyrone }\end{array}$ & $\begin{array}{l}\text { TOTPAR } 6 \\
\text { (1) } 12.39 \\
\text { (2) } 6.89\end{array}$ & $\begin{array}{l}\text { (1) } 23 / 41 \\
\text { (2) } 10 / 39\end{array}$ & No data & $\begin{array}{l}\text { Over } 4 \mathrm{~h} \text { : } \\
\text { (1) } 2.4 \% \\
\text { (2) } 51 \%\end{array}$ \\
\hline Breivik 1984 & $\begin{array}{l}\text { (1) aspirin } 650 \mathrm{mg}, \mathrm{n}=29 \\
\text { (2) placebo, } \mathrm{n}=30 \\
\text { Also } 2 \text { doses of piroxicam }\end{array}$ & $\begin{array}{l}\text { SPID } 6 \\
\text { (1) } 3.61 \\
\text { (2) } 1.98\end{array}$ & $\begin{array}{l}\text { (1) } 9 / 29 \\
\text { (2) } 5 / 30\end{array}$ & No data & $\begin{array}{l}\text { Over } 6 \mathrm{~h} \text { : } \\
\text { (1) } 41 \% \\
\text { (2) } 67 \%\end{array}$ \\
\hline
\end{tabular}


(Continued)

\begin{tabular}{|c|c|c|c|c|c|}
\hline \multirow[t]{2}{*}{ Calimlim 1977} & $\begin{array}{l}\text { (1) aspirin } 650 \mathrm{mg}, \mathrm{n}=23 \\
\text { (2) placebo, } \mathrm{n}=26 \\
\text { Also } 2 \text { doses of pentazocine plus aspirin }\end{array}$ & $\begin{array}{l}\text { TOTPAR } 5 \\
\text { (1) } 12.11\end{array}$ & $\begin{array}{l}\text { (1) } 16 / 23 \\
\text { (2) } 13 / 26\end{array}$ & No data & $\begin{array}{l}\text { Over } 5 \mathrm{~h} \text { : } \\
\text { (1) } 35 \% \\
\text { (2) } 69 \%\end{array}$ \\
\hline & & (2) 9.24 & & & \\
\hline
\end{tabular}

\begin{tabular}{|c|c|c|c|c|c|}
\hline Clark 1989 & $\begin{array}{l}\text { (1) aspirin } 600 \mathrm{mg}, \mathrm{n}=40 \\
\text { (2) placebo, } \mathrm{n}=40 \\
\text { Also } 3 \text { doses of carprofen, } 1 \text { of diflunisal }\end{array}$ & $\begin{array}{l}\text { TOTPAR } 6 \\
\text { (1) } 7.5 \\
\text { (2) } 4.4\end{array}$ & $\begin{array}{l}\text { (1) } 12 / 40 \\
\text { (2) } 5 / 40\end{array}$ & $\begin{array}{l}\text { (1) } 4.7 \\
\text { (2) } 3.8\end{array}$ & $\begin{array}{l}\text { Over } 6 \mathrm{~h} \text { : } \\
\text { (1) } 55 \% \\
\text { (2) } 65 \% \text {, } \\
\text { Over } 8 \mathrm{~h} \text { : } \\
\text { (1) } 60 \% \\
\text { (2) } 78 \% \\
\text { Over } 12 \mathrm{~h} \text { : } \\
\text { (1) } 65 \% \\
\text { (2) } 87 \%\end{array}$ \\
\hline
\end{tabular}

\begin{tabular}{llllll}
\hline Cooper 1977 & $\begin{array}{l}\text { (1) aspirin } 325 \mathrm{mg}, \mathrm{n}=37 \\
\text { (2) aspirin } 650 \mathrm{mg}, \mathrm{n}=37\end{array}$ & TOTPAR 4 & (1) $13 / 37$ & No data \\
(3) placebo, $\mathrm{n}=40$ & (1) 5.35 & (2) $7 / 40$ & \\
Also 2 doses ibuprofen & (2) 3.36 & & \\
\end{tabular}

\begin{tabular}{lllll}
\hline Cooper 1979a & Study 2: & TOTPAR 4 & (1) $27 / 47$ & No data \\
& $\begin{array}{l}\text { (1) aspirin } 600 \mathrm{mg}, \mathrm{n}=47 \\
\text { (2) placebo, } \mathrm{n}=58\end{array}$ & (1) 8.4 & (2) $14 / 58$ & No data \\
& Also 2 doses indoprofen $(\mathrm{n}=96)$ & (2) 4.3 & & \\
\hline
\end{tabular}

\begin{tabular}{|c|c|c|c|c|c|}
\hline Cooper 1982 & $\begin{array}{l}\text { (1) aspirin } 650 \mathrm{mg}, \mathrm{n}=38 \\
\text { (2) placebo, } n=46 \\
\text { Also codeine, codeine plus aspirin, ibupro- } \\
\text { fen, } \\
\text { codeine plus ibuprofen }(n=165)\end{array}$ & $\begin{array}{l}\text { TOTPAR } 4 \\
\text { (1) } 5.66 \\
\text { (2) } 2.65\end{array}$ & $\begin{array}{l}\text { (1) } 14 / 38 \\
\text { (2) } 5 / 46\end{array}$ & $\begin{array}{l}\text { Mean } \\
\text { (1) } 2.97 \\
\text { (2) } 2.38\end{array}$ & No data \\
\hline
\end{tabular}

\begin{tabular}{|c|c|c|c|c|c|}
\hline Cooper 1983 & $\begin{array}{l}\text { (1) aspirin } 650 \mathrm{mg}, \mathrm{n}=43 \\
\text { (2) placebo, } n=44 \\
\text { Also } 2 \text { doses of suprofen }(\mathrm{n}=89)\end{array}$ & $\begin{array}{l}\text { TOTPAR } 6 \\
\text { (1) } 11.0 \\
\text { (2) } 7.27\end{array}$ & $\begin{array}{l}\text { (1) } 21 / 43 \\
\text { (2) } 13 / 44\end{array}$ & $\begin{array}{l}\text { Mean } \\
\text { (1) } 242 \mathrm{~min} \\
\text { (2) } 194 \mathrm{~min}\end{array}$ & No data \\
\hline
\end{tabular}

\begin{tabular}{|c|c|c|c|c|c|}
\hline Cooper 1986a & $\begin{array}{l}\text { Study C } \\
\text { (1) aspirin } 650 \mathrm{mg}, \mathrm{n}=40 \\
\text { (2) placebo, } \mathrm{n}=41 \\
\text { Also aspirin plus codeine and } 2 \text { doses of } \\
\text { suprofen }(\mathrm{n}=123 \text { ) }\end{array}$ & $\begin{array}{l}\text { TOTPAR } 6 \\
\text { (1) } 8.13 \\
\text { (2) } 3.59\end{array}$ & $\begin{array}{l}\text { (1) } 13 / 40 \\
\text { (2) } 3 / 41\end{array}$ & $\begin{array}{l}\text { Mean } \\
\text { (1) } 165 \mathrm{~min} \\
\text { (2) } 136 \mathrm{~min}\end{array}$ & No data \\
\hline Cooper 1988 & $\begin{array}{l}\text { (1) aspirin } 600 \mathrm{mg}, \mathrm{n}=29 \\
\text { (2) placebo, } n=33 \\
\text { Also } 3 \text { doses of flurbiprofen }(n=89)\end{array}$ & $\begin{array}{l}\text { TOTPAR } 6 \\
\text { (1) } 4.61 \\
\text { (2) } 2.60\end{array}$ & $\begin{array}{l}\text { (1) } 4 / 29 \\
\text { (2) } 1 / 33\end{array}$ & $\begin{array}{l}\text { Mean } \\
\text { (1) } 203 \mathrm{~min} \\
\text { (2) } 142 \mathrm{~min}\end{array}$ & No data \\
\hline
\end{tabular}

\begin{tabular}{|c|c|c|c|c|c|}
\hline Cooper 1991b & $\begin{array}{l}\text { (1) aspirin } 650 \mathrm{mg}, \mathrm{n}=46 \\
\text { (2) placebo, } \mathrm{n}=48 \\
\text { Also } 2 \text { doses of meclofenamate }\end{array}$ & $\begin{array}{l}\text { TOTPAR } 6 \\
\text { (1) } 6.22 \\
\text { (2) } 3.79\end{array}$ & $\begin{array}{l}\text { (1) } 11 / 46 \\
\text { (2) } 5 / 48\end{array}$ & $\begin{array}{l}\text { Mean } \\
\text { (1) } 3.1 \\
\text { (2) } 2.9\end{array}$ & No data \\
\hline Cooper 1992 & $\begin{array}{l}\text { (1) aspirin } 650 \mathrm{mg}, \mathrm{n}=28 \\
\text { (2) placebo, } \mathrm{n}=26 \\
\text { Also } 2 \text { doses oxaprozin }(\mathrm{n}=50)\end{array}$ & $\begin{array}{l}\text { SPID } 6 \\
\text { (1) } 1.67\end{array}$ & $\begin{array}{l}\text { (1) } 4 / 28 \\
\text { (2) } 0 / 26\end{array}$ & $\begin{array}{l}\text { (1) } 2.8 \\
\text { (2) } 1.8\end{array}$ & $\begin{array}{l}\text { Over } 6 \mathrm{~h} \text { : } \\
\text { (1) } 80 \% \\
\text { (2) } 88 \%\end{array}$ \\
\hline
\end{tabular}

Single dose oral aspirin for acute postoperative pain in adults (Review) 
(Continued)

(2) 0.19

Over $8 \mathrm{~h}$ :

(1) $92 \%$

(2) $92 \%$

\begin{tabular}{lllll}
\hline Coutinho 1976 & $\begin{array}{l}\text { (1) aspirin } 650 \mathrm{mg}, \mathrm{n}=15 \\
\text { (2) placebo, } \mathrm{n}=15\end{array}$ & (1) $13 / 15$ & No data \\
& $\begin{array}{l}\text { Also codeine, propoxyphene, 2 doses fen- } \\
\text { bufen }(\mathrm{n}=60)\end{array}$ & (1) 6.8 & (2) $6 / 15$ \\
& (2) 3.3 & & No data
\end{tabular}

\begin{tabular}{lllll}
\hline De Vroey 1977 & $\begin{array}{l}\text { (1) aspirin } 650 \mathrm{mg}, \mathrm{n}=32 \\
\text { (2) placebo, } \mathrm{n}=31\end{array}$ & SPID 6 & (1) $19 / 32$ & No data \\
Also 3 doses diflunisal & (1) 8.1 & (2) $1 / 31$ & \\
\end{tabular}

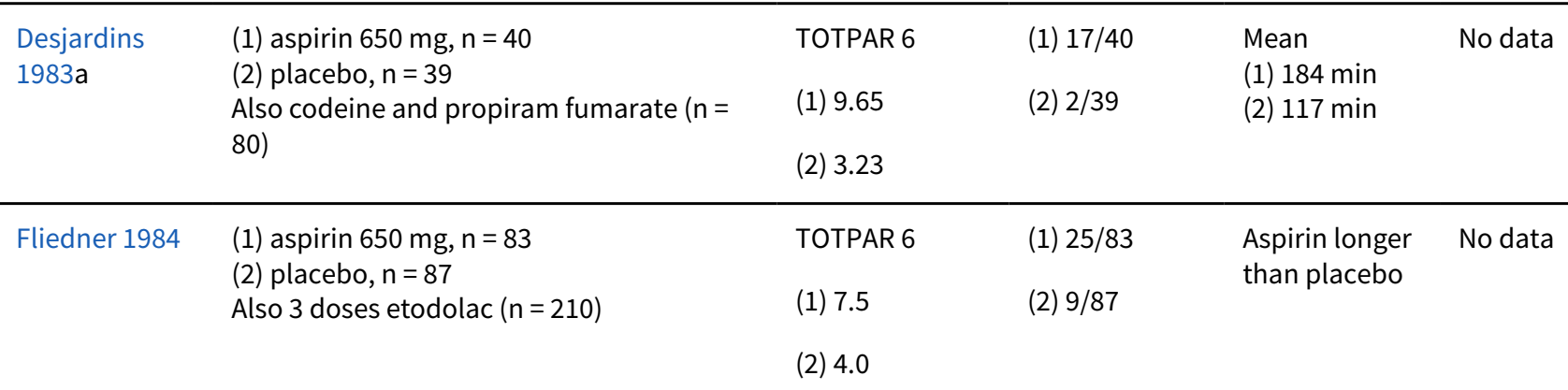

\begin{tabular}{llllll}
\hline Forbes 1980 & $\begin{array}{l}\text { (1) aspirin } 650 \mathrm{mg}, \mathrm{n}=38 \\
\text { (2) placebo, } \mathrm{n}=43\end{array}$ & TOTPAR 4 & (1) $15 / 38$ & Mean & No data \\
& Also 3 doses proquazone $(\mathrm{n}=129)$ & (1) 6.08 & (2) $4 / 43$ & (2) 2.4
\end{tabular}

\begin{tabular}{llllll}
\hline Forbes 1982 & $\begin{array}{l}\text { (1) aspirin } 650 \mathrm{mg}, \mathrm{n}=42 \\
\text { (2) placebo, } \mathrm{n}=38\end{array}$ & TOTPAR 4 & (1) $17 / 42$ & Mean & Over $12 \mathrm{~h}:$ \\
& & (1) 6.26 & (2) $9 / 38$ & (1) 3.1 & (2) 2.4 \\
(2) 4.21 & & & & $(2) 74 \%$ &
\end{tabular}

\begin{tabular}{|c|c|c|c|c|c|}
\hline Forbes 1983 & $\begin{array}{l}\text { (1) aspirin } 650 \mathrm{mg}, \mathrm{n}=39 \\
(2) \text { placebo, } \mathrm{n}=40 \\
\text { Also zomepirac and } 2 \text { doses of diflunisal ( } \mathrm{n} \\
=120 \text { ) }\end{array}$ & $\begin{array}{l}\text { TOTPAR } 6 \\
\text { (1) } 7.46 \\
\text { (2) } 4.07\end{array}$ & $\begin{array}{l}\text { (1) } 12 / 39 \\
\text { (2) } 4 / 40\end{array}$ & $\begin{array}{l}\text { Mean } \\
\text { (1) } 5.0 \\
\text { (2) } 4.6\end{array}$ & $\begin{array}{l}\text { Over } 6 \mathrm{~h} \text { : } \\
\text { (1) } 79 \% \\
\text { (2) } 80 \% \\
\text { Over } 8 \mathrm{~h} \text { : } \\
\text { (1) } 90 \% \\
\text { (2) } 83 \% \\
\text { Over } 12 \mathrm{~h} \text { : } \\
\text { (1) } 97 \% \\
\text { (2) } 90 \%\end{array}$ \\
\hline
\end{tabular}

\begin{tabular}{llllll}
\hline Forbes 1984 & $\begin{array}{l}\text { (1) aspirin } 650 \mathrm{mg}, \mathrm{n}=24 \\
\text { (2) placebo, } \mathrm{n}=28\end{array}$ & TOTPAR 6 & (1) $6 / 24$ & Mean & Over $12 \mathrm{~h}:$ \\
& Also ibuprofen and fendosal $(\mathrm{n}=57)$ & (1) 6.67 & (2) $3 / 28$ & (1) 5.3 & (1) $92 \%$ \\
& & (2) 3.79 & & & $(2) 89 \%$ \\
\hline
\end{tabular}

\begin{tabular}{|c|c|c|c|c|c|}
\hline Forbes 1986 & $\begin{array}{l}\text { (1) aspirin } 650 \mathrm{mg}, \mathrm{n}=36 \\
\text { (2) placebo, } n=42 \\
\text { Also naproxen, codeine and naproxen plus } \\
\text { codeine }(n=158)\end{array}$ & $\begin{array}{l}\text { TOTPAR } 6 \\
\text { (1) } 6.89 \\
\text { (2) } 4.07\end{array}$ & $\begin{array}{l}\text { (1) } 10 / 36 \\
\text { (2) } 5 / 42\end{array}$ & $\begin{array}{l}\text { Mean } \\
\text { (1) } 5.4 \\
\text { (2) } 5.3\end{array}$ & No data \\
\hline
\end{tabular}

\begin{tabular}{|c|c|c|c|c|c|}
\hline Forbes 1989 & (1) aspirin $600 \mathrm{mg}, \mathrm{n}=31$ & TOTPAR 6 & (1) $9 / 31$ & Mean & Over $8 \mathrm{~h}$ : \\
\hline
\end{tabular}

Copyright ๑ 2019 The Cochrane Collaboration. Published by John Wiley \& Sons, Ltd. 
(Continued)
(2) placebo, $n=33$
(1) 7.12
(2) $3 / 33$
(1) 5.1
(1) $77 \%$
Also 3 doses flurbiprofen $(n=100)$
(2) 3.49
(2) 3.3
(2) $94 \%$

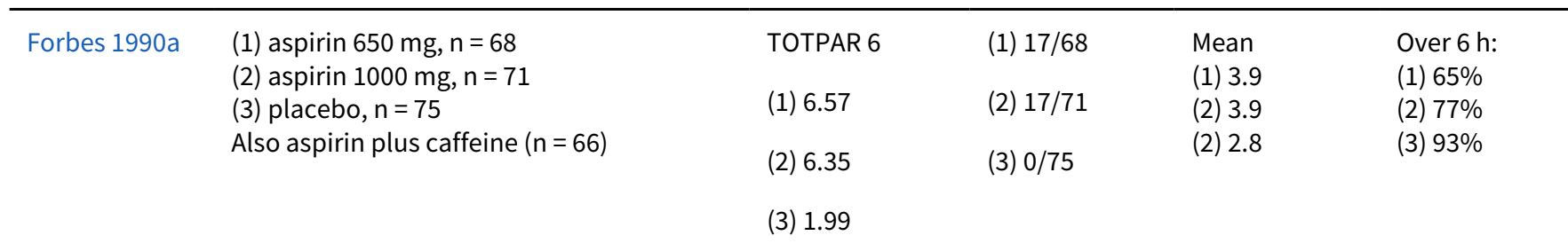

\begin{tabular}{llllll}
\hline Forbes $1990 \mathrm{~b}$ & $\begin{array}{l}\text { (1) aspirin } 650 \mathrm{mg}, \mathrm{n}=32 \\
\text { (2) placebo, } \mathrm{n}=32\end{array}$ & TOTPAR 6 & (1) $8 / 32$ & Mean & Over $6 \mathrm{~h}$ : \\
& $\begin{array}{l}\text { Also ketorolac and paracetamol plus } \\
\text { codeine }(\mathrm{n}=64)\end{array}$ & (1) 6.5 & (2) $1 / 32$ & (1) 4.2 & (2) 3.1 \\
& (2) 2.91 & & & $(2) 84 \%$ \\
\end{tabular}

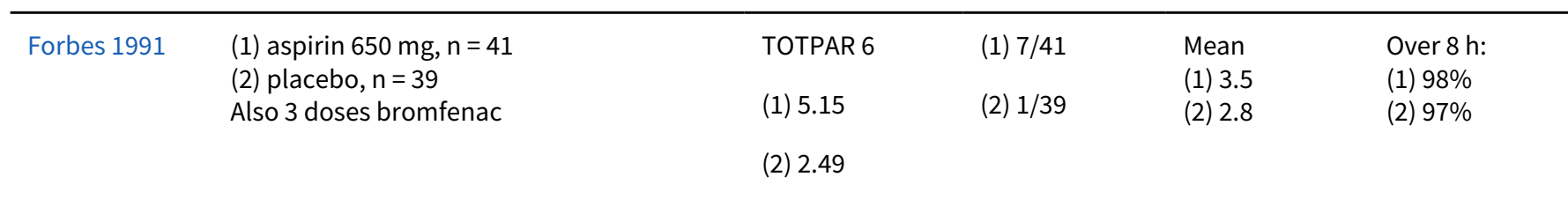

\begin{tabular}{llllll}
\hline Forbes 1992 & $\begin{array}{l}\text { (1) aspirin } 650 \mathrm{mg}, \mathrm{n}=38 \\
\text { (2) placebo, } \mathrm{n}=38\end{array}$ & TOTPAR 6 & (1) $8 / 38$ & Mean & Over $8 \mathrm{~h}:$ \\
& $\begin{array}{l}\text { Also ibuprofen and 3 doses bromfenac }(\mathrm{n}= \\
\text { 204) }\end{array}$ & (1) 5.81 & (2) $0 / 38$ & $(1) 3.9$ & $(1) 97 \%$ \\
(2) 2.06 & & & $(2) 2.7$ & $(2) 97 \%$ \\
\end{tabular}

\begin{tabular}{llllll}
\hline Frame 1986 & $\begin{array}{l}\text { (1) aspirin } 600 \mathrm{mg}, \mathrm{n}=25 \\
\text { (2) placebo, } \mathrm{n}=26\end{array}$ & TOTPAR 5 & (1) $14 / 25$ & (1) 2.9 & $\begin{array}{l}\text { Over } 5 \mathrm{~h} \text { : } \\
(1) 64 \%\end{array}$ \\
& $\begin{array}{l}\text { Also 3 doses ibuprofen plus codeine }(\mathrm{n}=4) \\
\end{array}$ & (1) 10.06 & (2) $12 / 26$ & (2) 2.6 & (2) $78 \%$ \\
\hline
\end{tabular}

\begin{tabular}{llllll}
\hline Gaston 1984 & $\begin{array}{l}\text { (1) aspirin } 650 \mathrm{mg}, \mathrm{n}=40 \\
\text { (2) placebo, } \mathrm{n}=42\end{array}$ & TOTPAR 6 & (1) $9 / 40$ & No data & No data \\
& & (1) 5.99 & (2) 4.8 & (2) $6 / 42$ &
\end{tabular}

\begin{tabular}{lllll}
\hline Gaston 1986 & (1) aspirin $650 \mathrm{mg}, \mathrm{n}=38$ & TOTPAR 6 & (1) $8 / 38$ & No data \\
& (2) placebo, $\mathrm{n}=38$ & (1) 5.8 & No data \\
& Also 3 doses etodolac $(\mathrm{n}=113)$ & (2) 3.9 & (2) $4 / 38$ & \\
\hline
\end{tabular}

\begin{tabular}{|c|c|c|c|c|c|}
\hline $\begin{array}{l}\text { Herbertson } \\
1994\end{array}$ & $\begin{array}{l}\text { (1) aspirin } 650 \mathrm{mg}, \mathrm{n}=53 \\
\text { (2) placebo, } \mathrm{n}=52 \\
\text { Also } 2 \text { doses diclofenac }\end{array}$ & $\begin{array}{l}\text { TOTPAR } 6 \\
\text { (1) } 10.2 \\
\text { (2) } 3.54\end{array}$ & $\begin{array}{l}\text { (1) } 23 / 50 \\
\text { (2) } 4 / 47\end{array}$ & $\begin{array}{l}\text { (1) } 4.4 \\
\text { (2) } 1.4\end{array}$ & $\begin{array}{l}\text { Over } 6 \mathrm{~h} \text { : } \\
\text { (1) } 70 \% \\
\text { (2) } 80 \% \\
\text { Over } 8 \mathrm{~h}: \\
\text { (1) } 90 \% \\
\text { (2) } 80 \%\end{array}$ \\
\hline
\end{tabular}

\begin{tabular}{|c|c|c|c|c|c|}
\hline $\begin{array}{l}\text { Herrmann } \\
\text { 1980a } \\
\text { Study } 1\end{array}$ & $\begin{array}{l}\text { (1) aspirin } 1000 \mathrm{mg}, \mathrm{n}=50 \\
\text { (2) placebo, } n=50 \\
\text { Also } 2 \text { doses fluproquazone }(\mathrm{n}=103)\end{array}$ & $\begin{array}{l}\text { TOTPAR } 4 \\
\text { (1) } 9.2 \\
\text { (2) } 5.3\end{array}$ & $\begin{array}{l}\text { (1) } 32 / 50 \\
\text { (2) } 16 / 50\end{array}$ & No data & $\begin{array}{l}\text { Over } 4 \mathrm{~h} \text { : } \\
\text { (1) } 20 \% \\
\text { (2) } 50 \%\end{array}$ \\
\hline $\begin{array}{l}\text { Herrmann } \\
1980 b \\
\text { Study } 2\end{array}$ & $\begin{array}{l}\text { (1) aspirin } 1000 \mathrm{mg}, \mathrm{n}=40 \\
\text { (2) placebo, } \mathrm{n}=42 \\
\text { Also } 2 \text { doses fluproquazone }(\mathrm{n}=86)\end{array}$ & $\begin{array}{l}\text { TOTPAR } 4 \\
\text { (1) } 7.0 \\
\text { (2) } 2.62\end{array}$ & $\begin{array}{l}\text { (1) } 19 / 40 \\
\text { (2) } 4 / 42\end{array}$ & No data & $\begin{array}{l}\text { Over } 4 \mathrm{~h} \text { : } \\
\text { (1) } 10 \% \\
\text { (2) } 67 \%\end{array}$ \\
\hline Holland 1988 & $\begin{array}{l}\text { (1) aspirin } 600 \mathrm{mg}, \mathrm{n}=20 \\
\text { (2) sol aspirin } 600 \mathrm{mg}, \mathrm{n}=20 \\
\text { (3) asnirin } 90 \mathrm{m \sigma} n=20\end{array}$ & $\begin{array}{l}\text { VAS SPID } 5 \\
\text { (1) } 107.4\end{array}$ & $\begin{array}{l}\text { (1) } 6 / 20 \\
\text { (2) } 12 / 20\end{array}$ & No data & No data \\
\hline
\end{tabular}

Single dose oral aspirin for acute postoperative pain in adults (Review) 
(Continued)
(4) sol aspirin $900 \mathrm{mg}, \mathrm{n}=20$
(5) aspirin $1200 \mathrm{mg}, \mathrm{n}=20$
(6) sol aspirin $1200 \mathrm{mg}, \mathrm{n}=20$
(7) placebo, $n=20$
(8) sol placebo, $n=20$

(2) 200.8

(3) $8 / 20$

(3) 123.9

(4) $14 / 20$

(4) 215.0

(5) $13 / 20$

$\begin{array}{ll}\text { (5) } 194.8 & \text { (6) } 15 / 20 \\ \text { (6) } 226.7 & \text { (7) } 4 / 20 \\ \text { (7) } 75.1 & \text { (8) } 4 / 20\end{array}$

(8) 69.4

\begin{tabular}{lllll}
\hline Honig 1978a & $\begin{array}{l}\text { (1) aspirin } 600 \mathrm{mg}, \mathrm{n}=30 \\
\text { (2) placebo, } n=28\end{array}$ & SPID 6 & (1) $9 / 30$ & No data \\
& Also 3 doses diflunisal $(n=151)$ & (1) 3.74 & (2) $1 / 28$ & \\
& & (2) 0.96 & &
\end{tabular}

\begin{tabular}{lllll}
\hline Jain 1985a & (1) aspirin $600 \mathrm{mg}, \mathrm{n}=30$ & TOTPAR 5 & (1) $19 / 30$ & No data \\
& (2) placebo, $n=30$ & (1) 11.1 & No data \\
& Also 2 doses indoprofen $(n=60)$ & (2) 4.0 & (2) $4 / 30$ &
\end{tabular}

\begin{tabular}{|c|c|c|c|c|c|}
\hline Jain 1985b & $\begin{array}{l}\text { (1) aspirin } 600 \mathrm{mg}, \mathrm{n}=29 \\
\text { (2) placebo, } \mathrm{n}=29 \\
\text { Also } 3 \text { doses indoprofen }(\mathrm{n}=88)\end{array}$ & $\begin{array}{l}\text { TOTPAR } 4 \\
\text { (1) } 9.4 \\
\text { (2) } 6.2\end{array}$ & $\begin{array}{l}\text { (1) } 19 / 29 \\
\text { (2) } 12 / 29\end{array}$ & No data & $\begin{array}{l}\text { Over } 4 \mathrm{~h} \text { : } \\
\text { (1) } 10 \% \\
\text { (2) } 41 \%\end{array}$ \\
\hline Jain 1986a & $\begin{array}{l}\text { (1) aspirin } 600 \mathrm{mg}, \mathrm{n}=38 \\
\text { (2) placebo, } \mathrm{n}=40 \\
\text { Also amfenac }(\mathrm{n}=40)\end{array}$ & $\begin{array}{l}\text { TOTPAR } 4 \\
\text { (1) } 6.94 \\
\text { (2) } 4.79\end{array}$ & $\begin{array}{l}\text { (1) } 17 / 37 \\
\text { (2) } 11 / 39\end{array}$ & No data & $\begin{array}{l}\text { Over } 4 \text { h: } \\
\text { (1) } 37 \% \\
\text { (2) } 60 \%\end{array}$ \\
\hline
\end{tabular}

\begin{tabular}{|c|c|c|c|c|c|}
\hline Jain 1986b & $\begin{array}{l}\text { (1) aspirin } 650 \mathrm{mg}, \mathrm{n}=45 \\
\text { (2) placebo, } n=47 \\
\text { Also } 3 \text { doses ibuprofen }(n=136)\end{array}$ & $\begin{array}{l}\text { SPID } 6 \\
\text { (1) } 2.11 \\
(2)-1.73\end{array}$ & $\begin{array}{l}\text { (1) } 6 / 45 \\
\text { (2) } 0 / 47\end{array}$ & $\begin{array}{l}\text { Mean } \\
\text { (1) } 240 \mathrm{~min} \\
\text { (2) } 121 \mathrm{~min}\end{array}$ & $\begin{array}{l}\text { Over } 6 \mathrm{~h} \text { : } \\
\text { (1) } 73 \% \\
\text { (2) } 96 \%\end{array}$ \\
\hline Kempf 1987 & $\begin{array}{l}\text { (1) aspirin buffered } 600 \mathrm{mg}, \mathrm{n}=24 \\
\text { (2) placebo, } n=24 \\
\text { Also } 2 \text { doses meclofenamate }(n=50)\end{array}$ & $\begin{array}{l}\text { TOTPAR } 4 \\
\text { (1) } 4.54 \\
\text { (2) } 2.3\end{array}$ & $\begin{array}{l}\text { (1) } 6 / 24 \\
\text { (2) } 2 / 23\end{array}$ & No data & No data \\
\hline
\end{tabular}

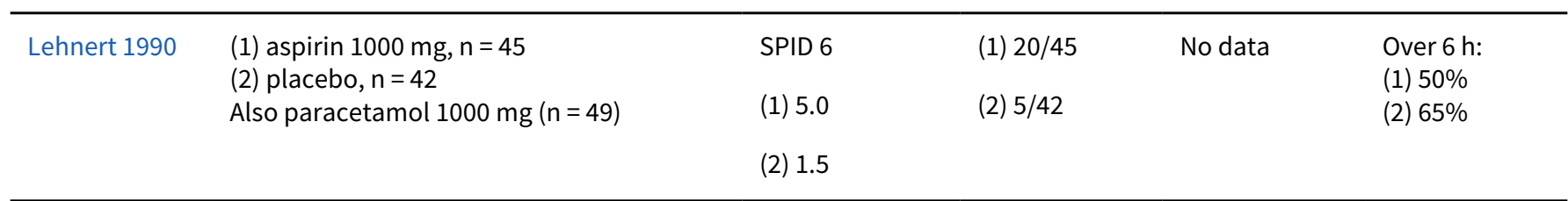

\begin{tabular}{|c|c|c|c|c|c|}
\hline London 1983a & $\begin{array}{l}\text { (1) aspirin } 650 \mathrm{mg}, \mathrm{n}=40 \\
\text { (2) placebo, } n=40 \\
\text { Also } 2 \text { doses fluproquazone }(\mathrm{n}=80)\end{array}$ & $\begin{array}{l}\text { PGE very good } \\
\text { or excellent } \\
\text { (1) } 12 / 40 \\
\text { (2) } 7 / 40\end{array}$ & $\begin{array}{l}\text { (1) } 12 / 40 \\
\text { (2) } 7 / 40\end{array}$ & No data & $\begin{array}{l}\text { Over } 4 \mathrm{~h} \text { : } \\
\text { (1) } 15 \% \\
\text { (2) } 40 \% \\
\text { Over } 6 \mathrm{~h} \text { : } \\
\text { (1) } 28 \% \\
\text { (2) } 63 \%\end{array}$ \\
\hline London 1983b & $\begin{array}{l}\text { (1) aspirin } 300 \mathrm{mg}, \mathrm{n}=40 \\
\text { (2) aspirin } 600 \mathrm{mg}, \mathrm{n}=41 \\
\text { (3) aspirin } 1200 \mathrm{mg}, \mathrm{n}=40 \\
\text { (4) placebo, } \mathrm{n}=39\end{array}$ & $\begin{array}{l}\text { SPID } 4 \\
\text { (1) } 3.29 \\
\text { (2) } 3.73 \\
\text { (3) } 4.38 \\
\text { (4) } 2.61\end{array}$ & $\begin{array}{l}\text { (1) } 19 / 40 \\
\text { (2) } 22 / 41 \\
\text { (3) } 25 / 40 \\
\text { (4) } 14 / 39\end{array}$ & No data & $\begin{array}{l}\text { Over } 4 \mathrm{~h} \text { : } \\
\text { (1) } 5 \% \\
\text { (2) } 7 \% \\
\text { (3) } 3 \% \\
\text { (4) } 25 \%\end{array}$ \\
\hline
\end{tabular}


(Continued)

\begin{tabular}{|c|c|c|c|c|c|}
\hline $\begin{array}{l}\text { Mardirossian } \\
1985\end{array}$ & $\begin{array}{l}\text { (1) aspirin } 650 \mathrm{mg}, \mathrm{n}=40 \\
\text { (2) placebo, } n=42 \\
\text { Also } 2 \text { doses of flurbiprofen }(n=82)\end{array}$ & $\begin{array}{l}\text { TOTPAR } 6 \\
\text { (1) } 7.15 \\
\text { (2) } 3.29\end{array}$ & $\begin{array}{l}\text { (1) } 11 / 40 \\
\text { (2) } 3 / 42\end{array}$ & $\begin{array}{l}\text { Mean } \\
\text { (1) } 216 \mathrm{~min} \\
\text { (2) } 175 \mathrm{~min}\end{array}$ & No data \\
\hline $\begin{array}{l}\text { Markowitz } \\
1985\end{array}$ & $\begin{array}{l}\text { (1) aspirin buffered } 600 \mathrm{mg}, \mathrm{n}=50 \\
\text { (2) placebo, } n=53 \\
\text { Also } 2 \text { doses meclofenamate }(n=102)\end{array}$ & $\begin{array}{l}\text { TOTPAR } 6 \\
\text { (1) } 4.74 \\
\text { (2) } 1.87\end{array}$ & $\begin{array}{l}\text { (1) } 5 / 47 \\
\text { (2) } 0 / 53\end{array}$ & No data & No data \\
\hline McQuay 1987 & $\begin{array}{l}\text { (1) aspirin } 650 \mathrm{mg}, \mathrm{n}=30 \\
\text { (2) placebo, } \mathrm{n}=30 \\
\text { Also } 2 \text { doses fluradoline }(\mathrm{n}=60)\end{array}$ & $\begin{array}{l}\text { TOTPAR } 6 \\
\text { (1) } 5.62 \\
\text { (2) } 2.57\end{array}$ & $\begin{array}{l}\text { (1) } 6 / 30 \\
\text { (2) } 1 / 30\end{array}$ & $\begin{array}{l}\text { (1) } 3.5 \\
\text { (2) } 2.0\end{array}$ & $\begin{array}{l}\text { Over } 6 \mathrm{~h}: \\
\text { (1) } 70 \% \\
\text { (2) } 87 \%\end{array}$ \\
\hline Mehlisch 1984 & $\begin{array}{l}\text { (1) aspirin } 650 \mathrm{mg}, \mathrm{n}=49 \\
\text { (2) placebo, } \mathrm{n}=55 \\
\text { Also paracetamol }(\mathrm{n}=58)\end{array}$ & $\begin{array}{l}\text { TOTPAR } 6 \\
\text { (1) } 5.51 \\
\text { (2) } 1.75\end{array}$ & $\begin{array}{l}\text { (1) } 9 / 49 \\
\text { (2) } 0 / 55\end{array}$ & No data & $\begin{array}{l}\text { Over } 4 \text { h: } \\
\text { (1) } 71 \% \\
\text { (2) } 89 \% \\
\text { Over } 6 \mathrm{~h} \text { : } \\
\text { (1) } 76 \% \\
\text { (2) } 95 \%\end{array}$ \\
\hline
\end{tabular}

\begin{tabular}{|c|c|c|c|c|c|}
\hline Mehlisch 1990 & $\begin{array}{l}\text { (1) aspirin } 650 \mathrm{mg}, \mathrm{n}=40 \\
\text { (2) placebo, } n=41 \\
\text { Also } 2 \text { doses FS 205-397 }(n=80)\end{array}$ & $\begin{array}{l}\text { TOTPAR } 6 \\
\text { (1) } 13.28 \\
\text { (2) } 9.32\end{array}$ & $\begin{array}{l}\text { (1) } 25 / 40 \\
\text { (2) } 16 / 41\end{array}$ & $\begin{array}{l}\text { Mean } \\
\text { (1) } 3.5 \\
\text { (2) } 2.4\end{array}$ & No data \\
\hline Mehlisch 1994 & $\begin{array}{l}\text { (1) aspirin } 650 \mathrm{mg}, \mathrm{n}=51 \\
\text { (2) placebo, } \mathrm{n}=52 \\
\text { Also } 2 \text { doses diclofenac }(\mathrm{n}=105)\end{array}$ & $\begin{array}{l}\text { TOTPAR } 6 \\
\text { (1) } 8.53 \\
\text { (2) } 3.09\end{array}$ & $\begin{array}{l}\text { (1) } 18 / 51 \\
\text { (2) } 3 / 52\end{array}$ & $\begin{array}{l}\text { (1) } 4.0 \\
\text { (2) } 1.8\end{array}$ & $\begin{array}{l}\text { Over } 4 \mathrm{~h} \text { : } \\
\text { (1) } 60 \% \\
\text { (2) } 80 \% \\
\text { Over } 6 \mathrm{~h} \text { : } \\
\text { (1) } 75 \% \\
\text { (2) } 87 \% \\
\text { Over } 6 \mathrm{~h} \text { : } \\
\text { (1) } 86 \% \\
\text { (2) } 94 \%\end{array}$ \\
\hline
\end{tabular}

\begin{tabular}{lllll}
\hline Nelson 1985 & (1) aspirin $650 \mathrm{mg}, \mathrm{n}=40$ & TOTPAR 6 & (1) $9 / 40$ & No data \\
& (2) placebo, $\mathrm{n}=39$ & (1) 6.13 & No data \\
& Also 3 doses etodolac $(\mathrm{n}=122)$ & (2) 3.28 & (2) $3 / 39$ &
\end{tabular}

\begin{tabular}{llllll}
\hline Nelson 1994a & (1) aspirin $500 \mathrm{mg}, \mathrm{n}=65$ & TOTPAR 6 & (1) $20 / 65$ & (1) $235 \mathrm{~min}$ & Over $6 \mathrm{~h}:$ \\
& (2) placebo, $\mathrm{n}=41$ & (1) 7.65 & (2) $174 \mathrm{~min}$ & $(1) 66 \%$ & $(2) 70 \%$ \\
& Also ibu lysine $(\mathrm{n}=77)$ & (2) 5.56 & (2) $8 / 41$ & & (2) \\
\hline
\end{tabular}

\begin{tabular}{llllll}
\hline Nelson 1994b & (1) aspirin $650 \mathrm{mg}, \mathrm{n}=51$ & TOTPAR 6 & (1) $26 / 50$ & (1) 8.0 & Over $8 \mathrm{~h}:$ \\
& (2) placebo, $\mathrm{n}=51$ & (1) 11.3 & (2) $4 / 50$ & (2) 2.7 & $(1) 51 \%$ \\
& Also 3 doses diclofenac (153) & (2) 3.65 & (2) $45 \%$ & $(2) 76 \%$ \\
\hline
\end{tabular}

\begin{tabular}{llllll}
\hline Olsen 1997 & (1) aspirin $650 \mathrm{mg}, \mathrm{n}=40$ & TOTPAR 4 & (1) $27 / 50$ & (1) 3.5 & At $6 \mathrm{~h}:$ \\
& (2) placebo, $\mathrm{n}=90$ & $(1) 8.0$ & & (2) 2.3 & (1) $10 \%$ \\
& & (2) 4.9 & (2) $15 / 52$ & & (2) $37 \%$
\end{tabular}

\begin{tabular}{|c|c|c|c|c|c|}
\hline Or 1988 & $\begin{array}{l}\text { (1) aspirin } 650 \mathrm{mg}, \mathrm{n}=27 \\
\text { (2) placebo, } n=27 \\
\text { Also mefenamic acid and mefenamic acid } \\
\text { plus aspirin }(n=54)\end{array}$ & $\begin{array}{l}\text { TOTPAR } 4 \\
\text { (1) } 8.3 \\
\text { (2) } 5.1\end{array}$ & $\begin{array}{l}\text { (1) } 16 / 27 \\
\text { (2) } 8 / 27\end{array}$ & No data & No data \\
\hline $\begin{array}{l}\text { Parkhouse } \\
1969\end{array}$ & $\begin{array}{l}\text { (1) aspirin } 600 \mathrm{mg} \text { tab, } \mathrm{n}=82 \\
\text { (2) aspirin } 600 \mathrm{mg} \text { fast buffered, } \mathrm{n}=87 \\
\text { (2) placebo, } \mathrm{n}=85\end{array}$ & $\begin{array}{l}\text { TOTPAR } 6 \\
\text { (1) } 13.0 \\
\text { (2) } 9.1\end{array}$ & $\begin{array}{l}\text { (1) } 31 / 82 \\
\text { (2) } 54 / 87 \\
\text { (3) } 29 / 85\end{array}$ & $\begin{array}{l}>6 \mathrm{~h} \text { for all } \\
\text { treatments }\end{array}$ & $\begin{array}{l}\text { Over } 4 \text { h: } \\
\text { (1) } 17 \% \\
\text { (2) } 17 \% \\
\text { (3) } 28 \% \\
\text { Over } 6 \text { h: }\end{array}$ \\
\hline
\end{tabular}


(Continued)
(3) 8.1
(1) $28 \%$

(2) $28 \%$

(3) $40 \%$

\begin{tabular}{lllll}
\hline Patel 1991 & (1) aspirin $650 \mathrm{mg}, \mathrm{n}=30$ & TOTPAR 6 & (1) $11 / 30$ & No data \\
& (2) placebo, $\mathrm{n}=30$ & (1) 8.9 & No data \\
& Also 3 doses lornoxicam $(\mathrm{n}=90)$ & (2) 7.8 & (2) $10 / 30$ & \\
\hline
\end{tabular}

\begin{tabular}{lllll}
\hline Rowe 1985 & (1) aspirin $600 \mathrm{mg}, \mathrm{n}=43$ & TOTPAR 6 & (1) $9 / 43$ & No data No data \\
& (2) placebo, $\mathrm{n}=41$ & (1) 5.84 & (2) $3 / 41$ & \\
& Also 2 doses meclofenate & (2) 3.47 & (2)
\end{tabular}

\begin{tabular}{|c|c|c|c|c|c|}
\hline Seymour 1986 & $\begin{array}{l}\text { (1) aspirin sol } 1200 \mathrm{mg}, \mathrm{n}=30 \\
\text { (2) aspirin tabs } 1200 \mathrm{mg}, \mathrm{n}=30 \\
\text { (3) placebo, } \mathrm{n}=30\end{array}$ & SPID 5 & $\begin{array}{l}\text { (1) } 32 / 60 \\
\text { (2) } 2 / 30\end{array}$ & No data & No data \\
\hline
\end{tabular}

\begin{tabular}{ll}
\hline Seymour 1992 & (1) aspirin buffered $500 \mathrm{mg}, \mathrm{n}=35$ \\
& (2) aspirin buffered $1000 \mathrm{mg}, \mathrm{n}=38$ \\
(3) aspirin tabs $500 \mathrm{mg}, \mathrm{n}=35$ \\
(4) aspirin tabs $1000 \mathrm{mg}, \mathrm{n}=37$ \\
(5) placebo, $\mathrm{n}=37$
\end{tabular}

$\begin{array}{ll}\text { VAS SPID } 5 & (1)+(3) 25 / 70 \\ \text { (1) } 65.0 & (2)+(4) 25 / 75 \\ \text { (2) } 72.25 & \text { (5) } 12 / 37 \\ \text { (3) } 117.5 & \\ \text { (4) } 91.5 & \\ \text { (5) } 88.25 & \end{array}$

$\begin{array}{ll}\text { (1) } 135 \min & \text { Over } 5 \mathrm{~h}: \\ \text { (2) } 135 \mathrm{~min} & \text { (1) } 30 / 35 \\ \text { (3) } 100 \mathrm{~min} & \text { (2) } 28 / 38 \\ \text { (4) } 95 \mathrm{~min} & \text { (3) } 25 / 35 \\ \text { (5) } 70 \mathrm{~min} & \text { (4) } 30 / 37 \\ & \text { (5) } 33 / 37\end{array}$

(5) 88.25

\begin{tabular}{llllll}
\hline Seymour 2003 & $\begin{array}{l}\text { (1) aspirin } 900 \mathrm{mg}, \mathrm{n}=59 \\
\text { (2) placebo, } \mathrm{n}=32\end{array}$ & VAS SPID 4 & (1) $25 / 59$ & 1) 1.9 & At $4 \mathrm{hrs:}$ \\
& & (1) 87.3 & (2) $3 / 32$ & 2) 1.1 & 1) $81 \%$ \\
(2) 22.6 & & & 2) $91 \%$
\end{tabular}

\begin{tabular}{|c|c|c|c|c|c|}
\hline $\begin{array}{l}\text { Sunshine } \\
1983 a\end{array}$ & $\begin{array}{l}\text { (1) aspirin } 650 \mathrm{mg}, \mathrm{n}=41 \\
\text { (2) placebo, } \mathrm{n}=40 \\
\text { Also aspirin plus codeine, and } 2 \text { doses } \\
\text { suprofen }\end{array}$ & $\begin{array}{l}\text { TOTPAR } 4 \\
\text { (1) } 12.25 \\
\text { (2) } 6.67\end{array}$ & $\begin{array}{l}\text { (1) } 27 / 30 \\
\text { (2) } 11 / 26\end{array}$ & No data & $\begin{array}{l}\text { Over } 4 \mathrm{~h} \text { : } \\
\text { (1) } 7 \% \\
\text { (2) } 48 \% \\
\text { Over } 6 \mathrm{~h} \text { : } \\
\text { (1) } 7 \% \\
\text { (2) } 48 \%\end{array}$ \\
\hline
\end{tabular}

\begin{tabular}{|c|c|c|c|c|c|}
\hline $\begin{array}{l}\text { Sunshine } \\
1983 b\end{array}$ & $\begin{array}{l}\text { (1) aspirin } 600 \mathrm{mg}, \mathrm{n}=29 \\
\text { (2) placebo, } n=31 \\
\text { Also } 3 \text { doses flurbiprofen }(\mathrm{n}=92)\end{array}$ & $\begin{array}{l}\text { TOTPAR } 6 \\
\text { (1) } 10.6 \\
\text { (2) } 2.3\end{array}$ & $\begin{array}{l}\text { (1) } 14 / 29 \\
\text { (2) } 0 / 31\end{array}$ & No data & $\begin{array}{l}\text { Over } 4 \text { h: } \\
\text { (1) } 0 \% \\
\text { (2) } 23 \% \\
\text { Over } 6 \text { h: } \\
\text { (1) } 3 \% \\
\text { (2) } 45 \%\end{array}$ \\
\hline
\end{tabular}

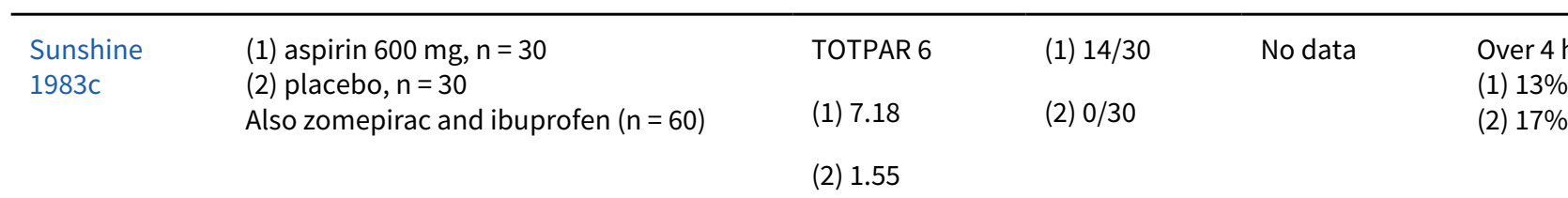

\begin{tabular}{|c|c|c|c|c|c|}
\hline Sunshine 1988 & $\begin{array}{l}\text { (1) aspirin } 648 \mathrm{mg}, \mathrm{n}=15 \\
\text { (2) placebo, } \mathrm{n}=15 \\
\text { Also } 2 \text { doses piroxicam }(\mathrm{n}=30)\end{array}$ & $\begin{array}{l}\text { TOTPAR } 6 \\
\text { (1) } 15.3 \\
\text { (2) } 7.3\end{array}$ & $\begin{array}{l}\text { (1) } 11 / 15 \\
\text { (2) } 4 / 15\end{array}$ & $\begin{array}{l}\text { (1) } 9.1 \\
\text { (2) } 5.6\end{array}$ & $\begin{array}{l}\text { Over } 24 \text { h: } \\
\text { (1) } 87 \% \\
\text { (2) no data }\end{array}$ \\
\hline Wang 1982 & $\begin{array}{l}\text { (1) aspirin } 650 \mathrm{mg}, \mathrm{n}=2 \\
\text { (2) placebo, } \mathrm{n}=25\end{array}$ & TOTPAR 6 & (1) $10 / 25$ & No data & No data \\
\hline
\end{tabular}


(Continued)
Also 2 doses bicifadine $(n=50)$
(1) 8.95
(2) $2 / 25$

(2) 3.83

\begin{tabular}{|c|c|c|c|c|c|}
\hline \multirow[t]{2}{*}{ Winter 1983a } & \multirow[t]{2}{*}{$\begin{array}{l}\text { (1) aspirin } 650 \mathrm{mg}, \mathrm{n}=37 \\
\text { (2) placebo, } n=35 \\
\text { Also oxaprozin }(n=33)\end{array}$} & $\begin{array}{l}\text { SPID } 6 \\
\text { (1) } 7.9\end{array}$ & $\begin{array}{l}\text { (1) } 24 / 37 \\
\text { (2) } 12 / 35\end{array}$ & \multirow[t]{2}{*}{ No data } & \multirow[t]{2}{*}{$\begin{array}{l}\text { Over } 8 \mathrm{~h} \text { : } \\
\text { (1) } 41 \% \\
\text { (2) } 60 \%\end{array}$} \\
\hline & & (2) 4.3 & & & \\
\hline \multirow[t]{3}{*}{ Winter $1983 b$} & \multirow{3}{*}{$\begin{array}{l}\text { (1) aspirin } 650 \mathrm{mg}, \mathrm{n}=42 \\
\text { (2) placebo, } \mathrm{n}=44 \\
\text { Also phenyltoloxamine plus paracetamol } \\
(\mathrm{n}=41)\end{array}$} & TOTPAR 4 & (1) $17 / 42$ & \multirow[t]{3}{*}{ No data } & \multirow[t]{3}{*}{ No data } \\
\hline & & (1) 6.19 & (2) $12 / 44$ & & \\
\hline & & (2) 4.76 & & & \\
\hline
\end{tabular}

$P G E=$ patient global assessment of efficacy; $P I=$ pain intensity; $P R=$ pain relief; $S P I D=$ summed pain intensity difference; $T O T P A R=$ summed total pain relief; VAS = visual analogue scale

\section{Appendix 6. Summary of outcomes: adverse events and withdrawals}

\begin{tabular}{|c|c|c|c|c|c|}
\hline & & Adverse events & & Withdrawals & \\
\hline Study ID & Treatment & Any & Serious & $\begin{array}{l}\text { Adverse } \\
\text { event }\end{array}$ & Other \\
\hline $\begin{array}{l}\text { Bloomfield } \\
1967\end{array}$ & $\begin{array}{l}\text { (1) aspirin } 600 \mathrm{mg}, \mathrm{n}=16 \\
\text { (2) placebo, } n=18 \\
\text { Also } 3 \text { doses of chlorphenesin } \\
(n=50)\end{array}$ & $\begin{array}{l}\text { (1) } 3 / 16 \\
\text { (2) } 1 / 18\end{array}$ & No data & No data & $\begin{array}{l}4 \text { pts randomised, but did } \\
\text { not complete study and ex- } \\
\text { cluded from analyses }\end{array}$ \\
\hline Boraks 1987 & $\begin{array}{l}\text { (1) aspirin } 650 \mathrm{mg}, \mathrm{n}=41 \\
\text { (2) placebo, } \mathrm{n}=39 \\
\text { Also flurbiprofen and dipy- } \\
\text { rone }\end{array}$ & $\begin{array}{l}\text { No usable da- } \\
\text { ta }\end{array}$ & No data & No data & No data \\
\hline Breivik 1984 & $\begin{array}{l}\text { (1) aspirin } 650 \mathrm{mg}, \mathrm{n}=29 \\
\text { (2) placebo, } \mathrm{n}=30 \\
\text { Also } 2 \text { doses of piroxicam }\end{array}$ & $\begin{array}{l}\text { No GI discom- } \\
\text { fort or nau- } \\
\text { sea, or other } \\
\text { symptom at- } \\
\text { tributable to } \\
\text { study medica- } \\
\text { tion }\end{array}$ & None & None reported & None \\
\hline Calimlim 1977 & $\begin{array}{l}\text { (1) aspirin } 650 \mathrm{mg}, \mathrm{n}=23 \\
\text { (2) placebo, } \mathrm{n}=26 \\
\text { Also } 2 \text { doses of pentazocine } \\
\text { plus aspirin }\end{array}$ & $\begin{array}{l}\text { No usable da- } \\
\text { ta }\end{array}$ & No data & None reported & $\begin{array}{l}2 \text { pts randomised but did } \\
\text { not provide data (not linked } \\
\text { to study med) }\end{array}$ \\
\hline Clark 1989 & $\begin{array}{l}\text { (1) aspirin } 600 \mathrm{mg}, \mathrm{n}=40 \\
\text { (2) placebo, } \mathrm{n}=40 \\
\text { Also } 3 \text { doses of carprofen, } 1 \text { of } \\
\text { diflunisal }\end{array}$ & $\begin{array}{l}\text { (1) } 9 / 40 \\
\text { (2) } 4 / 40 \\
\text { Most mild or } \\
\text { moderate }\end{array}$ & None reported & None & $\begin{array}{l}30 \text { pts did not take medica- } \\
\text { tion, } 11 \text { pts had invalid data } \\
\text { due to protocol violations }\end{array}$ \\
\hline Cooper 1977 & $\begin{array}{l}\text { (1) aspirin } 325 \mathrm{mg}, \mathrm{n}=37 \\
\text { (2) aspirin } 650 \mathrm{mg}, \mathrm{n}=37 \\
\text { (3) placebo, } \mathrm{n}=40\end{array}$ & $\begin{array}{l}\text { No significant } \\
\text { difference be- }\end{array}$ & None & None & $\begin{array}{l}53 \text { pts excluded for unin- } \\
\text { terpretable form (17), con- } \\
\text { founding medication (12), }\end{array}$ \\
\hline
\end{tabular}

Single dose oral aspirin for acute postoperative pain in adults (Review) 
(Continued)

Also 2 doses ibuprofen tween treat-

ment groups loss to follow-up (10), inadequate baseline pain (9), asleep after $1 \mathrm{~h}(5)$

\begin{tabular}{|c|c|c|c|c|}
\hline Cooper 1979a & $\begin{array}{l}\text { Study 2: } \\
\text { (1) aspirin } 600 \mathrm{mg}, \mathrm{n}=47 \\
\text { (2) placebo, } \mathrm{n}=58 \\
\text { Also } 2 \text { doses indoprofen ( } \mathrm{n}= \\
\text { 96) }\end{array}$ & $\begin{array}{l}\text { (1) } 8 / 54 \\
\text { (2) } 0 / 61 \\
\text { All mild }\end{array}$ & None & None \\
\hline Cooper 1982 & $\begin{array}{l}\text { (1) aspirin } 650 \mathrm{mg}, \mathrm{n}=38 \\
\text { (2) placebo, } n=46 \\
\text { Also codeine, codeine plus as- } \\
\text { pirin, ibuprofen, codeine plus } \\
\text { ibuprofen }(n=165)\end{array}$ & $\begin{array}{l}\text { (1) } 9 / 38 \\
\text { (2) } 5 / 46 \\
\text { Most mild or } \\
\text { moderate }\end{array}$ & None reported & None \\
\hline Cooper 1983 & $\begin{array}{l}\text { (1) aspirin } 650 \mathrm{mg}, \mathrm{n}=43 \\
\text { (2) placebo, } \mathrm{n}=44 \\
\text { Also } 2 \text { doses of suprofen ( } \mathrm{n}= \\
\text { 89) }\end{array}$ & $\begin{array}{l}\text { (1) } 3 / 43 \\
\text { (2) } 5 / 44 \\
\text { Generally } \\
\text { "minor" }\end{array}$ & None reported & None \\
\hline
\end{tabular}

27 pts excluded for falling asleep (10), inaccurate timing (8), incorrect medication (7), confounding medication (2)
67 pts originally randomised excluded for loss to follow-up (30), incorrect administration of medication (31), missing observations (6)
60 pts originally randomised excluded for loss to follow-up (3), did not take medication (37), took rescue medication $<1 \mathrm{~h}(7)$, other protocol violations (13)

\begin{tabular}{|c|c|c|c|c|c|}
\hline Cooper 1986a & $\begin{array}{l}\text { Study } C \\
\text { (1) aspirin } 650 \mathrm{mg}, \mathrm{n}=40 \\
\text { (2) placebo, } \mathrm{n}=41 \\
\text { Also aspirin plus codeine and } \\
2 \text { doses of suprofen }(\mathrm{n}=123)\end{array}$ & $\begin{array}{l}\text { (1) } 4 / 40 \\
\text { (2) } 5 / 41\end{array}$ & None reported & None & $\begin{array}{l}7 \text { pts randomised, but ex- } \\
\text { cluded from analyses for } \\
\text { loss to follow-up (4), took } \\
\text { rescue medication }<1 \mathrm{~h} \mathrm{(3)}\end{array}$ \\
\hline Cooper 1988 & $\begin{array}{l}\text { (1) aspirin } 600 \mathrm{mg}, \mathrm{n}=29 \\
\text { (2) placebo, } \mathrm{n}=33 \\
\text { Also } 3 \text { doses of flurbiprofen ( } \mathrm{n} \\
=89 \text { ) }\end{array}$ & $\begin{array}{l}\text { (1) } 10 / 30 \\
\text { (2) } 12 / 33 \\
\text { No unexpect- } \\
\text { ed events, } \\
\text { none could be } \\
\text { directly linked } \\
\text { to study drugs }\end{array}$ & None reported & None & $\begin{array}{l}8 \text { pts randomised but ex- } \\
\text { cluded from analyses for } \\
\text { loss to follow-up, rescue } \\
\text { medication }<1 \text { h, asleep } \\
\text { during observation times, } \\
\text { uninterpretable responses, } \\
\text { surgical complication, con- } \\
\text { founding medication, inap- } \\
\text { propriate administration, } \\
\text { vomiting soon after taking } \\
\text { medication }\end{array}$ \\
\hline Cooper 1991b & $\begin{array}{l}\text { (1) aspirin } 650 \mathrm{mg}, \mathrm{n}=46 \\
\text { (2) placebo, } \mathrm{n}=48 \\
\text { Also } 2 \text { doses of meclofena- } \\
\text { mate }\end{array}$ & $\begin{array}{l}\text { (1) } 8 / 46 \\
\text { (2) } 6 / 48 \\
\text { Most mild to } \\
\text { moderate }\end{array}$ & None reported & None & $\begin{array}{l}7 \text { pts randomised, but ex- } \\
\text { cluded from analyses for } \\
\text { protocol violations - miss- } \\
\text { ing observations, early } \\
\text { remedication }\end{array}$ \\
\hline Cooper 1992 & $\begin{array}{l}\text { (1) aspirin } 650 \mathrm{mg}, \mathrm{n}=28 \\
\text { (2) placebo, } n=26 \\
\text { Also } 2 \text { doses oxaprozin }(n=50)\end{array}$ & $\begin{array}{l}\text { (1) } 3 / 28 \\
\text { (2) } 3 / 26 \\
\text { All mild and } \\
\text { transient }\end{array}$ & None & None & $\begin{array}{l}8 \text { pts randomised but ex- } \\
\text { cluded from analyses for } \\
\text { loss to follow-up, rescue } \\
\text { medication }<1 \mathrm{~h} \text {, insuffi- } \\
\text { cient baseline pain }\end{array}$ \\
\hline Coutinho 1976 & $\begin{array}{l}\text { (1) aspirin } 650 \mathrm{mg}, \mathrm{n}=15 \\
\text { (2) placebo, } \mathrm{n}=15 \\
\text { Also codeine, propoxyphene, } \\
2 \text { doses fenbufen }(\mathrm{n}=60)\end{array}$ & $\begin{array}{l}\text { (1) } 4 / 15 \\
\text { (2) } 0 / 15 \\
\text { But this as- } \\
\text { sumes no- }\end{array}$ & None & None reported & $\begin{array}{l}21 \text { pts did not complete trial } \\
\text { - no further details }\end{array}$ \\
\hline
\end{tabular}

Single dose oral aspirin for acute postoperative pain in adults (Review) 
(Continued)

body had $>1$

event

\begin{tabular}{|c|c|c|c|c|c|}
\hline De Vroey 1977 & $\begin{array}{l}\text { (1) aspirin } 650 \mathrm{mg}, \mathrm{n}=32 \\
\text { (2) placebo, } \mathrm{n}=31 \\
\text { Also } 3 \text { doses diflunisal }\end{array}$ & $\begin{array}{l}\text { (1) } 1 / 32 \\
\text { (2) } 0 / 31\end{array}$ & None & None & $\begin{array}{l}\text { LoE: } \\
\text { (1) } 0 / 32 \\
\text { (2) } 3 / 31\end{array}$ \\
\hline $\begin{array}{l}\text { Desjardins } \\
1983 a\end{array}$ & $\begin{array}{l}\text { (1) aspirin } 650 \mathrm{mg}, \mathrm{n}=40 \\
\text { (2) placebo, } n=39 \\
\text { Also codeine and propiram fu- } \\
\text { marate }(\mathrm{n}=80)\end{array}$ & $\begin{array}{l}\text { (1) } 14 / 40 \\
\text { (2) } 7 / 39\end{array}$ & None & None & $\begin{array}{l}1 \text { pt randomised to placebo } \\
\text { was lost to follow up }\end{array}$ \\
\hline Fliedner 1984 & $\begin{array}{l}\text { (1) aspirin } 650 \mathrm{mg}, \mathrm{n}=83 \\
\text { (2) placebo, } \mathrm{n}=87 \\
\text { Also } 3 \text { doses etodolac }(\mathrm{n}=210)\end{array}$ & $\begin{array}{l}\text { (1) } 13 / 85 \\
\text { (2) } 9 / 87 \\
\text { Most mild and } \\
\text { self limiting }\end{array}$ & None & None & $\begin{array}{l}4 \text { pts randomised, but ex- } \\
\text { cluded from analyses for } \\
\text { loss to follow-up and con- } \\
\text { founding medication } \\
\text { LoE: } 1 \text { pt (etodolac) }\end{array}$ \\
\hline Forbes 1980 & $\begin{array}{l}\text { (1) aspirin } 650 \mathrm{mg}, \mathrm{n}=38 \\
\text { (2) placebo, } \mathrm{n}=43 \\
\text { Also } 3 \text { doses proquazone }(\mathrm{n}= \\
\text { 129) }\end{array}$ & $\begin{array}{l}\text { (1) } 2 / 38 \\
\text { (2) } 2 / 43 \\
\text { (before res- } \\
\text { cue medica- } \\
\text { tion) } \\
\text { All transitory }\end{array}$ & None & None & $\begin{array}{l}4 \text { pts lost to follow-up, } 15 \\
\text { did not need analgesic, } 20 \\
\text { pts had invalid efficacy data } \\
\text { (fell asleep, early remedica- } \\
\text { tion, code broken, invalid } \\
\text { entry, vomiting soon after } \\
\text { taking study medication) }\end{array}$ \\
\hline Forbes 1982 & $\begin{array}{l}\text { (1) aspirin } 650 \mathrm{mg}, \mathrm{n}=42 \\
\text { (2) placebo, } \mathrm{n}=38\end{array}$ & $\begin{array}{l}\text { (1) } 0 / 42 \\
\text { (2) no usable } \\
\text { data } \\
\text { All transient }\end{array}$ & None & None & $\begin{array}{l}11 \text { pts from all groups ex- } \\
\text { cluded from efficacy analy- } \\
\text { ses due to protocol viola- } \\
\text { tions }\end{array}$ \\
\hline Forbes 1983 & $\begin{array}{l}\text { (1) aspirin } 650 \mathrm{mg}, \mathrm{n}=39 \\
\text { (2) placebo, } n=40 \\
\text { Also zomepirac and } 2 \text { doses of } \\
\text { diflunisal }(\mathrm{n}=120)\end{array}$ & $\begin{array}{l}\text { (1) } 4 / 42 \\
\text { (2) } 9 / 42 \\
\text { All transitory }\end{array}$ & None & None & $\begin{array}{l}2 \text { pts did not return forms, } \\
11 \text { did not need analgesic, } \\
10 \text { had invalid efficacy data } \\
\text { (early remedication, did not } \\
\text { follow instructions) }\end{array}$ \\
\hline Forbes 1984 & $\begin{array}{l}\text { (1) aspirin } 650 \mathrm{mg}, \mathrm{n}=24 \\
\text { (2) placebo, } \mathrm{n}=28 \\
\text { Also ibuprofen and fendosal } \\
(\mathrm{n}=57)\end{array}$ & $\begin{array}{l}\text { (1) } 3 / 25 \\
\text { (2) } 3 / 30 \\
\text { All transito- } \\
\text { ry, did not re- } \\
\text { quire treat- } \\
\text { ment }\end{array}$ & None & None & $\begin{array}{l}21 \text { pts did not need anal- } \\
\text { gesic, } 6 \text { had invalid efficacy } \\
\text { data }\end{array}$ \\
\hline Forbes 1986 & $\begin{array}{l}\text { (1) aspirin } 650 \mathrm{mg}, \mathrm{n}=36 \\
\text { (2) placebo, } \mathrm{n}=42 \\
\text { Also naproxen, codeine, and } \\
\text { naproxen plus codeine }(\mathrm{n}= \\
\text { 158) }\end{array}$ & $\begin{array}{l}\text { (1) } 3 / 41 \\
\text { (2) } 7 / 46 \\
\text { (before res- } \\
\text { cue medica- } \\
\text { tion) } \\
\text { All transitory }\end{array}$ & None & None & $\begin{array}{l}46 \text { pts did not need anal- } \\
\text { gesic, } 24 \text { had invalid effica- } \\
\text { cy data (inappropriate med- } \\
\text { ication, incomplete evalu- } \\
\text { ations, surgical complica- } \\
\text { tion) }\end{array}$ \\
\hline Forbes 1989 & $\begin{array}{l}\text { (1) aspirin } 600 \mathrm{mg}, \mathrm{n}=31 \\
\text { (2) placebo, } \mathrm{n}=33 \\
\text { Also } 3 \text { doses flurbiprofen ( } \mathrm{n}= \\
\text { 100) }\end{array}$ & $\begin{array}{l}\text { (1) } 5 / 38 \\
\text { (2) } 1 / 39 \\
\text { (before res- } \\
\text { cue medica- } \\
\text { tion) } \\
\text { All transitory }\end{array}$ & None & None & $\begin{array}{l}26 \text { pts did not need anal- } \\
\text { gesic, } 24 \text { had invalid effica- } \\
\text { cy data (inappropriate med- } \\
\text { ication or rescue medica- } \\
\text { tion, incomplete evalua- } \\
\text { tions) }\end{array}$ \\
\hline
\end{tabular}


(Continued)

\begin{tabular}{|c|c|c|c|c|c|}
\hline Forbes 1990a & $\begin{array}{l}\text { (1) aspirin } 650 \mathrm{mg}, \mathrm{n}=68 \\
\text { (2) aspirin } 1000 \mathrm{mg}, \mathrm{n}=71 \\
\text { (3) placebo, } \mathrm{n}=75 \\
\text { Also aspirin plus caffeine }(\mathrm{n}= \\
66 \text { ) }\end{array}$ & $\begin{array}{l}\text { (1) } 8 / 68 \\
\text { (2) } 5 / 71 \\
\text { (3) } 6 / 75 \\
\text { (before res- } \\
\text { cue medica- } \\
\text { tion) } \\
\text { All transito- } \\
\text { ry, did not re- } \\
\text { quire treat- } \\
\text { ment }\end{array}$ & None & None & $\begin{array}{l}3 \text { pts lost to follow-up, } 43 \\
\text { did not need analgesic, } 51 \\
\text { had invalid efficacy data (in- } \\
\text { appropriate medication or } \\
\text { rescue medication, incon- } \\
\text { sistent data, vomiting soon } \\
\text { after taking medication) }\end{array}$ \\
\hline Forbes 1990b & $\begin{array}{l}\text { (1) aspirin } 650 \mathrm{mg}, \mathrm{n}=32 \\
(2) \text { placebo, } \mathrm{n}=32 \\
\text { Also ketorolac and paraceta- } \\
\text { mol plus codeine }(\mathrm{n}=64)\end{array}$ & $\begin{array}{l}\text { (1) } 4 / 38 \\
\text { (2) } 5 / 34 \\
\text { (before } 2 n d \\
\text { dose) }\end{array}$ & None & None & $\begin{array}{l}19 \text { pts did not need anal- } \\
\text { gesic, } 14 \text { had invalid effica- } \\
\text { cy data (inappropriate med- } \\
\text { ication or rescue medica- } \\
\text { tion, vomiting soon after } \\
\text { taking study medication) }\end{array}$ \\
\hline Forbes 1991 & $\begin{array}{l}\text { (1) aspirin } 650 \mathrm{mg}, \mathrm{n}=41 \\
\text { (2) placebo, } \mathrm{n}=39 \\
\text { Also } 3 \text { doses bromfenac }\end{array}$ & $\begin{array}{l}\text { (1) } 3 / 46 \\
\text { (2) } 3 / 47 \\
\text { (before res- } \\
\text { cue medica- } \\
\text { tion) } \\
\text { All transito- } \\
\text { ry, did not re- } \\
\text { quire treat- } \\
\text { ment }\end{array}$ & None & None & $\begin{array}{l}7 \text { pts lost to follow up, } 12 \\
\text { did not need analgesic, } 28 \\
\text { had invalid efficacy data (in- } \\
\text { appropriate medication or } \\
\text { rescue med, inconsistent or } \\
\text { incomplete data) }\end{array}$ \\
\hline Forbes 1992 & $\begin{array}{l}\text { (1) aspirin } 650 \mathrm{mg}, \mathrm{n}=38 \\
\text { (2) placebo, } \mathrm{n}=38 \\
\text { Also ibuprofen and } 3 \text { doses } \\
\text { bromfenac }(\mathrm{n}=204)\end{array}$ & $\begin{array}{l}\text { (1) 5/44 } \\
\text { (2) } 2 / 46 \\
\text { (before res- } \\
\text { cue medica- } \\
\text { tion) } \\
\text { All transito- } \\
\text { ry, did not re- } \\
\text { quire treat- } \\
\text { ment }\end{array}$ & None & None & $\begin{array}{l}3 \text { pts lost to follow-up, } 14 \\
\text { did not need analgesic, } 41 \\
\text { had invalid efficacy data (in- } \\
\text { appropriate rescue medica- } \\
\text { tion, incomplete or incon- } \\
\text { sistent data) }\end{array}$ \\
\hline Frame 1986 & $\begin{array}{l}\text { (1) aspirin } 600 \mathrm{mg}, \mathrm{n}=25 \\
\text { (2) placebo, } n=26 \\
\text { Also } 3 \text { doses ibuprofen plus } \\
\text { codeine }(n=4)\end{array}$ & $\begin{array}{l}\text { (1) } 2 / 25 \\
\text { (2) } 1 / 26\end{array}$ & None & None & $\begin{array}{l}6 \text { pts did not need anal- } \\
\text { gesic, } 12 \text { took medication } \\
\text { incorrectly, } 12 \text { lost to fol- } \\
\text { low-up or incomplete data }\end{array}$ \\
\hline Gaston 1984 & $\begin{array}{l}\text { (1) aspirin } 650 \mathrm{mg}, \mathrm{n}=40 \\
\text { (2) placebo, } \mathrm{n}=42\end{array}$ & $\begin{array}{l}\text { (1) } 1 / 40 \\
\text { (2) } 0 / 42\end{array}$ & None & None & None reported \\
\hline Gaston 1986 & $\begin{array}{l}\text { (1) aspirin } 650 \mathrm{mg}, \mathrm{n}=38 \\
\text { (2) placebo, } n=38 \\
\text { Also } 3 \text { doses etodolac }(n=113)\end{array}$ & $\begin{array}{l}\text { (1) } 3 / 38 \\
\text { (2) } 3 / 38 \\
\text { Most mild to } \\
\text { moderate, all } \\
\text { self limiting }\end{array}$ & None & None & $\begin{array}{l}\text { All pts who took drug were } \\
\text { included in analyses }\end{array}$ \\
\hline $\begin{array}{l}\text { Herbertson } \\
1994\end{array}$ & $\begin{array}{l}\text { (1) aspirin } 650 \mathrm{mg}, \mathrm{n}=53 \\
\text { (2) placebo, } \mathrm{n}=52 \\
\text { Also } 2 \text { doses diclofenac }\end{array}$ & $\begin{array}{l}\text { "medical } \\
\text { problems" } \\
\text { (1) } 5 / 54 \\
\text { (2) } 2 / 54 \\
\text { All consid- } \\
\text { ered possibly } \\
\text { drug-related }\end{array}$ & None & $\begin{array}{l}8 \text { pts with- } \\
\text { drew due } \\
\text { to "medical } \\
\text { problems", } \\
\text { only } 1 \text { was } \\
\text { drug-relat- } \\
\text { ed (nausea + }\end{array}$ & None reported \\
\hline
\end{tabular}


(Continued)

All mild or vomiting with

moderate diclofenac)

\begin{tabular}{ll}
\hline $\begin{array}{l}\text { Herrmann } \\
\text { 1980a }\end{array}$ & $\begin{array}{l}\text { (1) aspirin } 1000 \mathrm{mg}, \mathrm{n}=50 \\
\text { (2) placebo, } \mathrm{n}=50\end{array}$ \\
& $\begin{array}{l}\text { Also } 2 \text { doses fluproquazone ( } \\
=103)\end{array}$ \\
\hline Herrmann & $\begin{array}{l}\text { (1) aspirin } 1000 \mathrm{mg}, \mathrm{n}=40 \\
\text { 1980b }\end{array}$ \\
$\begin{array}{l}\text { (2) placebo, } \mathrm{n}=42 \\
\text { Study 2 }\end{array}$ & $\begin{array}{l}\text { Also } 2 \text { doses fluproquazone ( } \\
=86)\end{array}$
\end{tabular}

Data are provided for 4 studies combined, 2 of which are excluded studies

$\begin{array}{ll}\text { Holland } 1988 & \text { (1) aspirin } 600 \mathrm{mg}, \mathrm{n}=20 \\ \text { (2) sol aspirin } 600 \mathrm{mg}, \mathrm{n}=20 \\ \text { (3) aspirin } 900 \mathrm{mg}, \mathrm{n}=20 \\ \text { (4) sol aspirin } 900 \mathrm{mg}, \mathrm{n}=20 \\ \text { (5) aspirin } 1200 \mathrm{mg}, \mathrm{n}=20 \\ \text { (6) sol aspirin } 1200 \mathrm{mg}, \mathrm{n}=20 \\ \text { (7) placebo, } \mathrm{n}=20 \\ \text { (8) sol placebo, } \mathrm{n}=20\end{array}$

(3) $1 / 20 \quad$ None None None

(6) $2 / 20$

Mild and tran-

sient

Honig 1978 a

$\begin{array}{llll}\text { (1) aspirin } 600 \mathrm{mg}, \mathrm{n}=30 & \text { (1) } 0 / 30 & \text { None } & \text { None } \\ \text { (2) placebo, } \mathrm{n}=28 & \text { (2) } 0 / 28 & & \end{array}$

Also 3 doses diflunisal $(\mathrm{n}=$

151)

$\begin{array}{ll}\text { Jain 1985a } & \begin{array}{l}\text { (1) aspirin } 600 \mathrm{mg}, \mathrm{n}=30 \quad \text { None } \\ \text { (2) placebo, } \mathrm{n}=30 \\ \text { Also } 2 \text { doses indoprofen }(\mathrm{n}= \\ 60)\end{array} \\ & \end{array}$

\begin{tabular}{lllll}
\hline Jain $1985 b$ & (1) aspirin $600 \mathrm{mg}, \mathrm{n}=29$ & (1) $1 / 29$ & None & None \\
& (2) placebo, $\mathrm{n}=29$ & (2) $0 / 30$ & &
\end{tabular}

Also 3 doses indoprofen $(n=$

88)

\begin{tabular}{lllll}
\hline Jain 1986a & (1) aspirin $600 \mathrm{mg}, \mathrm{n}=38$ & (1) $0 / 39$ & None & None \\
& (2) placebo, $n=40$ & (2) $5 / 41$ & & \\
& Also amfenac $(n=40)$ & &
\end{tabular}

\begin{tabular}{|c|c|c|c|c|c|}
\hline Jain 1986b & $\begin{array}{l}\text { (1) aspirin } 650 \mathrm{mg}, \mathrm{n}=45 \\
\text { (2) placebo, } \mathrm{n}=47 \\
\text { Also } 3 \text { doses ibuprofen }(\mathrm{n}= \\
\text { 136) }\end{array}$ & $\begin{array}{l}\text { (1) } 6 / 52 \\
\text { (2) } 12 / 52\end{array}$ & None & None & $\begin{array}{l}33 \text { pts randomised but ex- } \\
\text { cluded from efficacy analy- } \\
\text { ses due to early remedica- } \\
\text { tion (10), did not need anal- } \\
\text { gesic or loss to follow-up } \\
\text { (19), missing data, con- } \\
\text { founding medication, mild } \\
\text { baseline pain }\end{array}$ \\
\hline
\end{tabular}


(Continued)

\begin{tabular}{|c|c|c|c|c|c|}
\hline Kempf 1987 & $\begin{array}{l}\text { (1) aspirin buffered } 600 \mathrm{mg}, \mathrm{n} \\
=24 \\
(2) \text { placebo, } n=24 \\
\text { Also } 2 \text { doses meclofenamate } \\
(\mathrm{n}=50)\end{array}$ & $\begin{array}{l}\text { (1) } 3 / 26 \\
\text { (2) } 1 / 26\end{array}$ & None & None & $\begin{array}{l}7 \text { pts had missing data for } \\
\text { PI, } 11 \text { for PR - excluded from } \\
\text { efficacy analyses }\end{array}$ \\
\hline Lehnert 1990 & $\begin{array}{l}\text { (1) aspirin } 1000 \mathrm{mg}, \mathrm{n}=45 \\
(2) \text { placebo, } \mathrm{n}=42 \\
\text { Also paracetamol } 1000 \mathrm{mg}(\mathrm{n} \\
=49)\end{array}$ & $\begin{array}{l}\text { (1) } 5 / 45 \\
\text { (2) } 4 / 42\end{array}$ & None & None & $\begin{array}{l}17 \text { pts excluded from analy- } \\
\text { ses due to loss to follow-up } \\
\text { (3), did not need analgesic } \\
\text { (11), violation of procedures } \\
\text { (3) }\end{array}$ \\
\hline London 1983a & $\begin{array}{l}\text { (1) aspirin } 650 \mathrm{mg}, \mathrm{n}=40 \\
\text { (2) placebo, } \mathrm{n}=40 \\
\text { Also } 2 \text { doses fluproquazone ( } \mathrm{n} \\
=80 \text { ) }\end{array}$ & $\begin{array}{l}\text { (1) } 2 / 40 \\
\text { (2) } 3 / 40 \\
\text { All mild or } \\
\text { moderate }\end{array}$ & None & None & $\begin{array}{l}6 \text { pts randomised but ex- } \\
\text { cluded from analyses since } \\
\text { did not follow protocol }\end{array}$ \\
\hline London 1983b & $\begin{array}{l}\text { (1) aspirin } 300 \mathrm{mg}, \mathrm{n}=40 \\
\text { (2) aspirin } 600 \mathrm{mg}, \mathrm{n}=41 \\
\text { (3) aspirin } 1200 \mathrm{mg}, \mathrm{n}=40 \\
\text { (4) placebo, } \mathrm{n}=39\end{array}$ & None & None & None & No data \\
\hline $\begin{array}{l}\text { Mardirossian } \\
1985\end{array}$ & $\begin{array}{l}\text { (1) aspirin } 650 \mathrm{mg}, \mathrm{n}=40 \\
\text { (2) placebo, } \mathrm{n}=42 \\
\text { Also } 2 \text { doses of flurbiprofen ( } \mathrm{n} \\
=82 \text { ) }\end{array}$ & $\begin{array}{l}\text { (1) } 13 / 40 \\
\text { (2) } 16 / 42 \\
\text { No unexpect- } \\
\text { ed events, } \\
\text { none could be } \\
\text { directly linked } \\
\text { to study drugs }\end{array}$ & None & None & $\begin{array}{l}7 \text { pts randomised but ex- } \\
\text { cluded from analyses for } \\
\text { loss to follow-up (2), inap- } \\
\text { propriate remedication ( } 2) \text {, } \\
\text { confounding medication } \\
(1), \text { broke code ( } 1) \text {, did not } \\
\text { take medication (1) }\end{array}$ \\
\hline McQuay 1987 & $\begin{array}{l}\text { (1) aspirin } 650 \mathrm{mg}, \mathrm{n}=30 \\
\text { (2) placebo, } \mathrm{n}=30 \\
\text { Also } 2 \text { doses fluradoline }(\mathrm{n}= \\
60)\end{array}$ & $\begin{array}{l}\text { (1) } 9 / 30 \\
\text { (2) } 11 / 30\end{array}$ & None & None & None \\
\hline Mehlisch 1984 & $\begin{array}{l}\text { (1) aspirin } 650 \mathrm{mg}, \mathrm{n}=49 \\
\text { (2) placebo, } \mathrm{n}=55 \\
\text { Also paracetamol }(\mathrm{n}=58)\end{array}$ & $\begin{array}{l}\text { No usable da- } \\
\text { ta } \\
\text { No significant } \\
\text { difference be- } \\
\text { tween aspirin } \\
\text { and placebo }\end{array}$ & No data & None & $\begin{array}{l}12 \text { pts randomised but ex- } \\
\text { cluded from analyses be- } \\
\text { cause loss to follow-up (3), } \\
\text { did not comply with proto- } \\
\text { col (9) }\end{array}$ \\
\hline Mehlisch 1990 & $\begin{array}{l}\text { (1) aspirin } 650 \mathrm{mg}, \mathrm{n}=40 \\
\text { (2) placebo, } \mathrm{n}=41 \\
\text { Also } 2 \text { doses FS 205-397 }(\mathrm{n}= \\
\text { 80) }\end{array}$ & $\begin{array}{l}\text { (1) } 6 / 40 \\
\text { (2) } 7 / 41 \\
\text { All mild or } \\
\text { moderate }\end{array}$ & None & None & None \\
\hline Mehlisch 1994 & $\begin{array}{l}\text { (1) aspirin } 650 \mathrm{mg}, \mathrm{n}=51 \\
\text { (2) placebo, } \mathrm{n}=52 \\
\text { Also } 2 \text { doses diclofenac }(\mathrm{n}= \\
\text { 105) }\end{array}$ & $\begin{array}{l}\text { (1) } 7 / 51 \\
\text { (2) } 4 / 52 \\
\text { All mild or } \\
\text { moderate }\end{array}$ & None & None & None \\
\hline
\end{tabular}


(Continued)

\begin{tabular}{|c|c|c|c|c|c|}
\hline Nelson 1985 & $\begin{array}{l}\text { (1) aspirin } 650 \mathrm{mg}, \mathrm{n}=40 \\
\text { (2) placebo, } n=39 \\
\text { Also } 3 \text { doses etodolac }(n=122)\end{array}$ & $\begin{array}{l}\text { No usable da- } \\
\text { ta } \\
\text { No significant } \\
\text { difference be- } \\
\text { tween aspirin } \\
\text { and placebo }\end{array}$ & No data & None & $\begin{array}{l}6 \text { pts randomised but ex- } \\
\text { cluded from analyses be- } \\
\text { cause } 3 \text { lost to follow-up, } \\
3 \text { dropped out before } 1 \mathrm{~h} \\
\text { evaluation }\end{array}$ \\
\hline Nelson 1994a & $\begin{array}{l}\text { (1) aspirin } 500 \mathrm{mg}, \mathrm{n}=65 \\
\text { (2) placebo, } \mathrm{n}=41 \\
\text { Also ibu lysine }(\mathrm{n}=77)\end{array}$ & $\begin{array}{l}\text { (1) } 13 / 65 \\
\text { (2) } 11 / 41\end{array}$ & None & None & $\begin{array}{l}3 \text { pts randomised but ex- } \\
\text { cluded from efficacy analy- } \\
\text { ses due to early remedica- } \\
\text { tion (2), failure to record } \\
\text { baseline pain (1) }\end{array}$ \\
\hline Nelson 1994b & $\begin{array}{l}\text { (1) aspirin } 650 \mathrm{mg}, \mathrm{n}=51 \\
\text { (2) placebo, } \mathrm{n}=51 \\
\text { Also } 3 \text { doses diclofenac (153) }\end{array}$ & $\begin{array}{l}\text { (1) } 4 / 51 \\
\text { (2) } 6 / 51\end{array}$ & None & None & $\begin{array}{l}3 \text { pts excluded from efficacy } \\
\text { analyses - no reason given }\end{array}$ \\
\hline Olsen 1997 & $\begin{array}{l}\text { (1) aspirin } 650 \mathrm{mg}, \mathrm{n}=40 \\
\text { (2) placebo, } \mathrm{n}=90\end{array}$ & $\begin{array}{l}\text { Probably } \\
\text { judged treat- } \\
\text { ment-related } \\
\text { (1) } 1 / 50 \\
\text { (2) } 1 / 52\end{array}$ & None & None & None \\
\hline Or 1988 & $\begin{array}{l}\text { (1) aspirin } 650 \mathrm{mg}, \mathrm{n}=27 \\
\text { (2) placebo, } \mathrm{n}=27 \\
\text { Also mefenamic acid and } \\
\text { mefenamic acid plus aspirin ( } \mathrm{n} \\
=54 \text { ) }\end{array}$ & $\begin{array}{l}\text { (1) } 5 / 27 \\
\text { (2) } 1 / 27 \\
\text { All mild and } \\
\text { transient }\end{array}$ & None & None & $\begin{array}{l}12 \text { pts had invalid efficacy } \\
\text { data, } 8 \text { did not follow pro- } \\
\text { tocol, } 4 \text { took confounding } \\
\text { medication }\end{array}$ \\
\hline $\begin{array}{l}\text { Parkhouse } \\
1969\end{array}$ & $\begin{array}{l}\text { (1) aspirin } 600 \mathrm{mg} \text { tab, } \mathrm{n}=82 \\
\text { (2) aspirin } 600 \mathrm{mg} \text { fast } \\
\text { buffered, } \mathrm{n}=87 \\
\text { (2) placebo, } \mathrm{n}=85\end{array}$ & $\begin{array}{l}\text { No usable da- } \\
\text { ta } \\
\text { Most mild or } \\
\text { moderate }\end{array}$ & No data & No data & No data \\
\hline
\end{tabular}

\begin{tabular}{|c|c|c|c|c|c|}
\hline Patel 1991 & $\begin{array}{l}\text { (1) aspirin } 650 \mathrm{mg}, \mathrm{n}=30 \\
\text { (2) placebo, } \mathrm{n}=30 \\
\text { Also } 3 \text { doses lornoxicam ( } \mathrm{n}= \\
\text { 90) }\end{array}$ & $\begin{array}{l}\text { (1) } 2 / 30 \\
\text { (2) } 2 / 30\end{array}$ & None & None & $\begin{array}{l}\text { Data reported for those who } \\
\text { completed trial according } \\
\text { to protocol }\end{array}$ \\
\hline Rowe 1985 & $\begin{array}{l}\text { (1) aspirin } 600 \mathrm{mg}, \mathrm{n}=43 \\
\text { (2) placebo, } \mathrm{n}=41 \\
\text { Also } 2 \text { doses meclofenate }\end{array}$ & $\begin{array}{l}\text { No usable da- } \\
\text { ta }\end{array}$ & None reported & None & Only LoE reported \\
\hline Seymour 1986 & $\begin{array}{l}\text { (1) aspirin sol } 1200 \mathrm{mg}, \mathrm{n}=30 \\
\text { (2) aspirin tabs } 1200 \mathrm{mg}, \mathrm{n}= \\
30 \\
\text { (3) placebo, } \mathrm{n}=30\end{array}$ & No data & No data & No data & No data \\
\hline Seymour 1992 & $\begin{array}{l}\text { (1) aspirin buffered } 500 \mathrm{mg}, \mathrm{n} \\
=35 \\
\text { (2) aspirin buffered } 1000 \mathrm{mg}, \mathrm{n} \\
=38 \\
\text { (3) aspirin tabs } 500 \mathrm{mg}, \mathrm{n}=35 \\
\text { (4) aspirin tabs } 1000 \mathrm{mg}, \mathrm{n}= \\
37 \\
\text { (5) placebo, } \mathrm{n}=37\end{array}$ & No data & No data & No data & No data \\
\hline Seymour 2003 & $\begin{array}{l}\text { (1) aspirin } 900 \mathrm{mg}, \mathrm{n}=59 \\
\text { (2) placebo, } \mathrm{n}=32\end{array}$ & $\begin{array}{l}\text { At } 4 \mathrm{h:} \\
\text { 1) } 51 / 59\end{array}$ & None & None & $\begin{array}{l}14 \text { pts enrolled but not ran- } \\
\text { domised: }\end{array}$ \\
\hline
\end{tabular}


2) $28 / 32 \quad 10$ - insufficient pain

2 - withdrew consent

1 - adverse reaction to

anaesthetic

1- protocol violator

\begin{tabular}{|c|c|c|c|c|c|}
\hline $\begin{array}{l}\text { Sunshine } \\
\text { 1983a }\end{array}$ & $\begin{array}{l}\text { (1) aspirin } 650 \mathrm{mg}, \mathrm{n}=41 \\
\text { (2) placebo, } \mathrm{n}=40 \\
\text { Also aspirin plus codeine, and } \\
2 \text { doses suprofen }\end{array}$ & $\begin{array}{l}\text { (1) } 3 / 42 \\
\text { (2) } 1 / 40\end{array}$ & None & None & $\begin{array}{l}46 \text { pts participated in study } \\
\text { twice. Results not used for } \\
\text { efficacy, but included in } \\
\text { safety. } 9 \text { pts excluded from } \\
\text { efficacy analyses for early } \\
\text { remedication }\end{array}$ \\
\hline $\begin{array}{l}\text { Sunshine } \\
\text { 1983b }\end{array}$ & $\begin{array}{l}\text { (1) aspirin } 600 \mathrm{mg}, \mathrm{n}=29 \\
\text { (2) placebo, } \mathrm{n}=31 \\
\text { Also } 3 \text { doses flurbiprofen }(\mathrm{n}= \\
\text { 92) }\end{array}$ & No data & No data & None & $\begin{array}{l}16 \text { pts excluded from all } \\
\text { analyses due to confound- } \\
\text { ing medication }\end{array}$ \\
\hline $\begin{array}{l}\text { Sunshine } \\
1983 c\end{array}$ & $\begin{array}{l}\text { (1) aspirin } 600 \mathrm{mg}, \mathrm{n}=30 \\
\text { (2) placebo, } \mathrm{n}=30 \\
\text { Also zomepirac and ibuprofen } \\
(\mathrm{n}=60)\end{array}$ & None & None & None & None \\
\hline Sunshine 1988 & $\begin{array}{l}\text { (1) aspirin } 648 \mathrm{mg}, \mathrm{n}=15 \\
\text { (2) placebo, } \mathrm{n}=15 \\
\text { Also } 2 \text { doses piroxicam }(\mathrm{n}=30)\end{array}$ & $\begin{array}{l}\text { (1) } 8 / 15 \\
\text { (2) } 5 / 15\end{array}$ & None reported & None & $\begin{array}{l}1 \text { pt excluded due to history } \\
\text { of drug abuse }\end{array}$ \\
\hline Wang 1982 & $\begin{array}{l}\text { (1) aspirin } 650 \mathrm{mg}, \mathrm{n}=2 \\
(2) \text { placebo, } n=25 \\
\text { Also } 2 \text { doses bicifadine }(n=50)\end{array}$ & No data & No data & No data & No data \\
\hline Winter 1983a & $\begin{array}{l}\text { (1) aspirin } 650 \mathrm{mg}, \mathrm{n}=37 \\
\text { (2) placebo, } \mathrm{n}=35 \\
\text { Also oxaprozin }(\mathrm{n}=33)\end{array}$ & No data & No data & None & $\begin{array}{l}22 \text { pts randomised but did } \\
\text { not experience moder- } \\
\text { ate/severe pain }\end{array}$ \\
\hline Winter 1983b & $\begin{array}{l}\text { (1) aspirin } 650 \mathrm{mg}, \mathrm{n}=42 \\
\text { (2) placebo, } \mathrm{n}=44 \\
\text { Also phenyltoloxamine plus } \\
\text { paracetamol }(\mathrm{n}=41)\end{array}$ & $\begin{array}{l}\text { No usable da- } \\
\text { ta }\end{array}$ & None & None & $\begin{array}{l}34 \text { pts randomised but ex- } \\
\text { cluded from analyses due } \\
\text { to lost to follow-up, did } \\
\text { not need analgesic, early } \\
\text { remedication, fell asleep, } \\
\text { confused answers }\end{array}$ \\
\hline
\end{tabular}

WHAT'S NEW

\begin{tabular}{lll}
\hline Date & Event & Description \\
\hline 29 May 2019 & Amended & Contact details updated. \\
\hline 11 October 2017 & Review declared as stable & No new studies likely to change the conclusions are expected. \\
\hline
\end{tabular}

\section{H ISTORY}

Protocol first published: Issue 3, 2000

Review first published: Issue 3, 2000 


\begin{tabular}{ll}
\hline Date Event Description & Den \\
\hline
\end{tabular}

\begin{tabular}{ll}
\hline 16 April 2015 & Review declared as stable \\
\hline 25 January 2012 & $\begin{array}{l}\text { New citation required but conclusions } \\
\text { have not changed }\end{array}$
\end{tabular}

To be assessed for further updating in 2020 .

New search with slightly more restrictive inclusion criteria, which excluded a small number of studies that included participants with pain following trauma rather than surgery. One new study identified, and included (Seymour 2003). New outcomes relating to use of rescue medication added: number of participants using rescue medication within specified times, and mean or median time to use of rescue medication. These are additional measures of efficacy, providing information on duration of analgesia, that have been identified as clinically useful by healthcare workers. We excluded five studies that were included in the earlier review because they included participants with pain due to trauma (Herrmann 1980c; Herrmann 1980d), fracture (Kantor 1965; Wang 1979) or fracture and musculoskeletal pain (Okun 1979), which are outside the scope of this update.

Results for participants with at least $50 \%$ pain relief over 4 to 6 hours, and participants experiencing adverse events, were not changed. The median time to use of rescue medication was about 5 hours with 600/650 mg aspirin, and the number needed to treat to prevent one participant needing rescue medication was 5 over 4 to 8 hours.

\begin{tabular}{lll}
\hline 25 January 2012 & New search has been performed & The search was brought up to date to January 2012. \\
\hline 8 February 2011 & Amended & Contact details updated. \\
\hline 24 September 2010 & Amended & Contact details updated. \\
\hline 4 July 2010 & Amended & $\begin{array}{l}\text { Jayne Rees reverted to Jayne Edwards so that Cochrane Library } \\
\text { citations will match bibliographic databases outside Cochrane }\end{array}$ \\
\hline 5 November 2008 & Amended & Minor amendment to what's new and to rest of text \\
\hline 21 April 2008 & Amended & Converted to new review format and synopsis included. \\
\hline
\end{tabular}

\section{CONTRIBUTIONS OFAUTHORS}

RAM and SD both carried out searches and reassessed the original trials for inclusion and new outcomes. SD entered the data into RevMan. Both authors were involved in analyses and writing. RAM and SD are responsible for updates.

\section{DECLARATIONS OF INTEREST}

RAM has consulted for various pharmaceutical companies and received lecture fees from pharmaceutical companies related to analgesics and other healthcare interventions. RAM and SD have received research support from charities, government and industry sources at various times. Support for this review came from Oxford Pain Research Funds.

\section{SOURCES OF SUPPORT}

\section{Internal sources}

- Pain Research Funds, UK.

\section{External sources}

- NHS R\&D Health Technology Evaluation programmes (\#93/31/4 and \#94/11/4), UK. 
For original review

- European Union Biomed 2 BMH4 CT95 0172, UK.

For original review

- SmithKline Beecham Consumer Healthcare, UK.

For original review

- Biotechnology and Biological Sciences Research Council, UK.

For original review

\section{DIFFERENCES BETWEEN PROTOCOL AND REVIEW}

There are no differences between protocol and review. The original review was conducted before the need for protocols, but it conforms in all essentials with protocols for recent reviews in this series for which protocols were prepared.

\section{INDEX TERMS}

\section{Medical Subject Headings (MeSH)}

Acute Disease; Administration, Oral; Analgesics, Non-Narcotic [ ${ }^{\star}$ administration \& dosage] [adverse effects]; Aspirin [ ${ }^{*}$ administration \& dosage] [adverse effects]; Pain, Postoperative [ ${ }^{\star}$ drug therapy]

\section{MeSH check words}

Adult; Humans 